UNIVERSIDADE FEDERAL DE JUIZ DE FORA

FACULDADE DE DIREITO

ISABEL CRISTINA CAMPOS VIEIRA DO NASCIMENTO

O PRINCIPIO DA RESERVA DO POSSÍVEL E A PONDERAÇÃO: UMA PROPOSTA DE CRITÉRIOS PARA ANÁLISE DA CONFIABILIDADE EPISTÊMICA DE PREMISSAS EMPÍRICAS E NORMATIVAS

JUIZ DE FORA 
O PRINCIPIO DA RESERVA DO POSSÍVEL E A PONDERAÇÃO: UMA PROPOSTA DE CRITÉRIOS PARA ANÁLISE DA CONFIABILIDADE EPISTÊMICA DE PREMISSAS EMPÍRICAS E NORMATIVAS

Dissertação apresentada ao Programa de Pós- Graduação Stricto Sensu da Faculdade de Direito da Universidade Federal de Juiz de Fora como requisito parcial para a obtenção do título de Mestre na área de concentração de Direito e Inovação. Área de concentração: Direito, Argumentação e Políticas Públicas: empiria e inovação na pesquisa jurídica.

Orientadora: Prof ${ }^{a}$. Dra. Cláudia Maria Toledo da Silveira. 
Ficha catalográfica elaborada através do programa de geração automática da Biblioteca Universitária da UFJF, com os dados fornecidos pelo(a) autor(a)

Nascimento, Isabel Cristina Campos Vieira do.

O Princípio da Reserva do Possível e a Ponderação : uma proposta de critérios para análise da confiabilidade epistêmica de premissas empíricas e normativas / Isabel Cristina Campos Vieira do Nascimento. -- 2021.

209 p. : il.

Orientadora: Cláudia Maria Toledo da Silveira

Dissertação (mestrado acadêmico) - Universidade Federal de Juiz de Fora, Faculdade de Direito. Programa de Pós-Graduação em Direito, 2021.

1. Reserva do Possível. 2. Ponderação. 3. Robert Alexy. 4. Premissas normativas e empíricas. 5. Confiabilidade epistêmica. I. Silveira, Cláudia Maria Toledo da, orient II. Título. 


\title{
O PRINCIPIO DA RESERVA DO POSSÍVEL E A PONDERAÇÃO: UMA PROPOSTA DE CRITÉRIOS PARA ANÁLISE DA CONFIABILIDADE EPISTÊMICA DE PREMISSAS EMPÍRICAS E NORMATIVAS
}

\begin{abstract}
Dissertação apresentada ao Programa de Pós Graduação Stricto Sensu da Faculdade de Direito da Universidade Federal de Juiz de Fora como requisito para a obtenção do título de Mestre na área de concentração de Direito e Inovação, sob a orientação da Prof ${ }^{a}$. Dra. Cláudia Maria Toledo da Silveira.
\end{abstract}

Aprovada em 30 de junho de 2021.

BANCA EXAMINADORA

Prof ${ }^{\mathrm{a}}$. Dra. Cláudia Maria Toledo da Silveira

Universidade Federal de Juiz de Fora

Prof $^{\mathrm{a}}$. Dra ${ }^{\mathrm{a}}$. Luciana Gaspar Melquíades Duarte

Universidade Federal de Juiz de Fora

Prof. Dr. Ingo Wolfgang Sarlet

Pontifícia Universidade Católica do Rio Grande do Sul 
Dedico este trabalho ao meu esposo e filhos que me apoiaram durante esse trabalho. 


\section{AGRADECIMENTOS}

Agradeço à minha família, especialmente meu esposo e filhos pelo apoio no decorrer de mais uma etapa de minha formação.

Agradeço ao Dr. Alex Fernandes Santiago, grande incentivador de meu aperfeiçoamento intelectual e profissional.

Agradeço aos amigos e colegas de Mestrado, em especial Camila Baeta e Isabela Miceli com quem compartilhei muito mais do que conhecimentos e dúvidas, mas uma grande amizade.

Agradeço a todos os professores do Mestrado em Direito e Inovação da UFJF pelas valiosas reflexões e pelo conhecimento compartilhado.

Agradeço à servidora Vanilda pelo carinho, gentileza e paciência em orientar-nos com prontidão sobre todos os procedimentos internos da instituição, sem os quais estaria inviabilizada a conclusão deste curso.

Por fim, à minha orientadora Prof. Dra. Claudia Toledo, um agradecimento especial pela oportunidade de fazer parte desse programa, sem a qual seria impensável sequer iniciar essa etapa, e também pelos conhecimentos compartilhados, pela seriedade, paciência e prontidão ao longo da realização desta pesquisa. 


\section{RESUMO}

Um número crescente de ações judiciais tem sido propostas na tentativa de garantir a efetivação de direitos constitucionalmente reconhecidos e, via de consequência, obstar a inércia ou a atuação deficitária da Administração Pública. A propositura dessas ações, em regra, objetiva a obtenção do cumprimento de obrigação de fazer, consistente em prestações materiais não ofertadas espontaneamente pelo Poder Público, e por consequência, o reconhecimento e a correção de eventuais omissões estatais na concretização dos direitos fundamentais. O principio da reserva do possível constitui, ao lado do princípio da separação dos poderes, o principal argumento a justificar a impossibilidade no atendimento a essas prestações e de outras obrigações estatais que envolvam o dispêndio de recursos públicos. Contudo, a abordagem do principio tem ocorrido sem a adoção de critérios técnicos suficientes para sua correta aplicação. Essa situação pode acarretar tanto a concessão de prestações indevidas, diante da ausência de prova processual adequada e que induz à incerteza das alegações e premissas apresentadas pelo Poder Público, quanto à denegação de prestações devidas e razoáveis, pelo apelo do senso comum que paira sobre a presunção da escassez de recursos públicos para o atendimento das prestações que concretizam direitos fundamentais. Permite, ainda, a proliferação de decisões contraditórias em situações semelhantes, em prejuízo da segurança jurídica e da isonomia no tratamento dos jurisdicionados. A pesquisa se divide em duas partes. A primeira, uma pesquisa bibliográfica exploratória e dedutiva sobre os aspectos teóricos do principio da reserva do possível, passando por sua conceituação, sua incorporação no ordenamento jurídico pátrio, de sua relação com as normas de direitos fundamentais e orçamentárias, até chegar ao levantamento de parâmetros objetivos para a aferição da confiabilidade epistêmica das premissas empírica e normativas, em consonância com a fórmula do peso refinada proposta pro Robert Alexy, o marco teórico utilizado. A segunda parte contém a pesquisa empírica realizada com o objetivo de quantificar a ocorrência dos parâmetros elencados na jurisprudência do Supremo Tribunal Federal e do Superior Tribunal de Justiça, de forma a avaliar o grau de confiabilidade epistêmica em que as decisões desses tribunais têm sido proferidas.

Palavras-chave: Reserva do Possível. 2. Ponderação. 3. Robert Alexy. 4. Premissas normativas e empíricas. 5. Confiabilidade epistêmica. 


\begin{abstract}
An increasing number of lawsuits have been proposed in an attempt to guarantee the enforcement of constitutionally recognized rights and, as a consequence, to prevent the inaction or deficient performance of the Public Administration. The filing of these actions, as a rule, aims to achieve compliance with the obligation to do, consisting of material benefits not spontaneously offered by the Public Power, and consequently, the recognition and correction of possible state omissions in the implementation of fundamental rights. The principle of reserving the possible constitutes, along with the principle of separation of powers, the main argument to justify the impossibility of meeting these benefits and other state obligations that involve the expenditure of public resources. However, the approach to the principle has occurred without the adoption of sufficient technical criteria for its correct application. This situation can result in both the granting of undue benefits, in the absence of adequate procedural evidence that leads to the uncertainty of the allegations and premises presented by the Government, as well as the denial of due and reasonable benefits, due to the common sense appeal that hangs over the presumption of scarcity of public resources for the provision of services that materialize fundamental rights. It also allows for the proliferation of contradictory decisions in similar situations, to the detriment of legal certainty and isonomy in the treatment of the courts. The research is divided into two parts. The first, an exploratory and deductive bibliographic research on the theoretical aspects of the principle of the reserve of the possible, passing through its conceptualization, its incorporation in the national legal system, its relationship with the fundamental rights and budgetary rules, until reaching the survey of parameters objectives for measuring the epistemic reliability of the empirical and normative premises, in line with the refined weight formula proposed by Robert Alexy, the theoretical framework used. The second part contains the empirical research carried out in order to quantify the occurrence of the parameters listed in the jurisprudence of the Federal Supreme Court and the Superior Court of Justice, in order to assess the degree of epistemic reliability in which the decisions of these courts have been handed down.
\end{abstract}

Keywords: Reservation of the possible. 2. Balancing 3. Robert Alexy. 4. Normative and empirical premisses. 5. Epistemic reliability 


\section{LISTA DE ILUSTRAÇÕES}

Gráfico 1 - Parâmetros da confiabilidade epistêmica empírica - STF .....................160

Gráfico 2 - Parâmetros da confiabilidade epistêmica empírica - STJ ......................161

Gráfico 3 - Parâmetros de confiabilidade epistêmica normativa - STF ....................163

Gráfico 4 - Parâmetros de confiabilidade epistêmica normativa - STJ .....................165

Gráfico 5 - Graus de confiabilidade epistêmica sugeridos - STF ........................166

Gráfico 6 - Graus de confiabilidade epistêmica sugeridos - STJ....................... 166

Quadro 1 - Tabulação cruzada - pesquisa jurisprudencial STF .........................192

Quadro 2 - Tabulação cruzada - pesquisa jurisprudencial STJ..........................193 


\section{LISTA DE SIGLAS E ABREVIATURAS}

ADI - Ação Direta de Inconstitucionalidade

ADC - Ação Direta de Constitucionalidadae

ADPF - Arguição de Descumprimento de Preceito Fundamental

AGU - Advocacia Geral da União

AgR - Agravo Regimental

AI - Agravo de Instrumento

ARE - Recurso Extraordinário com Agravo

BPC - Benefício de Prestação Continuada

BVerfGE - Bundesverfassungsgericht

CF/88 - Constituição Federal de 1988

EC - Emenda Constitucional

ED - Embargos de Declaração

FUNPEN - Fundo Penitenciário Nacional

IF - Intervenção Federal

INSS - Instituto Nacional do Seguro Social

LDO - Lei de Diretrizes Orçamentárias

LOA - Lei Orçamentária Anual

LRF - Lei de Responsabilidade Fiscal

MC - Medida Cautelar

NCPC - Novo Código de Processo Civil

PEC - Proposta de Emenda Constitucional

PGR - Procuradoria Geral da República

PPA - Plano Plurianual

Rcl - Reclamação

Resp - Recurso Especial

RE - Recurso Extraordinário

RISTF- Regulamento Interno do STF

RREO - Relatórios Resumidos de Execução Orçamentária

STF - Supremo Tribunal Federal

STJ - Superior Tribunal de Justiça 


\section{SUMÁRIO}

INTRODUÇÃO

PARTE I - ELEMENTOS TEÓRICOS DO PRINCÍPIO DA RESERVA DO

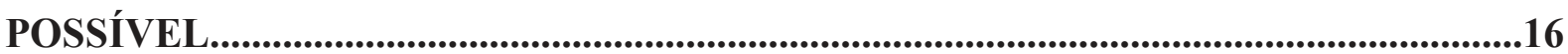

1 O CONCEITO DO PRINCÍPIO DA RESERVA DO POSSÍVEL ................................16

1.1 O CONTEXTO JURÍDICO DE SURGIMENTO DA RESERVA DO

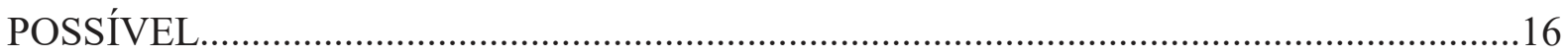

1.2 O TRATAMENTO DA RESERVA DO POSSÍVEL NA JURISPRUDÊNCIA E NA

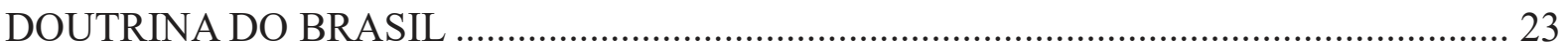

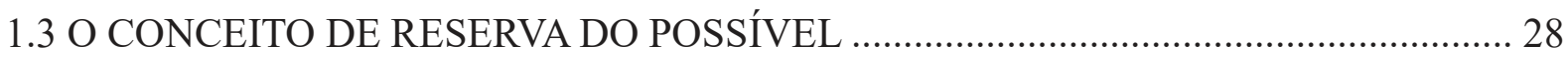

2. OS DIREITOS FUNDAMENTAIS E O PRINCÍPIO DA RESERVA DO

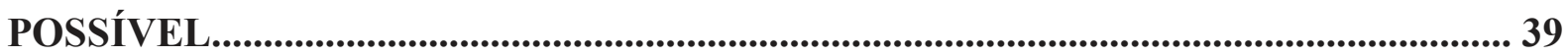

2.1 A CONSTITUCIONALIZAÇÃO DOS DIREITOS FUNDAMENTAIS........................... 39

2.2 O CARÁTER PRESTACIONAL DOS DIREITOS FUNDAMENTAIS E OS CUSTOS

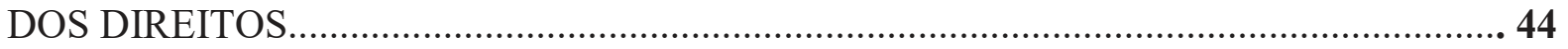

2.3 RESTRIÇÕES A DIREITOS FUNDAMENTAIS: BREVES CONSIDERAÇÕES SOBRE A TEORIA INTERNA (INNENTHEORIE) E A TEORIA EXTERNA (AUSSENTHEORIE) E O PRINCÍPIO DA RESERVA DO POSSÍVEL ………………………………………...... 54

2.4 LIMITES À APLICAÇÃO DO PRINCÍPIO DA RESERVA DO POSSÍVEL: TEORIA DAS “RESTRIÇÕES ÀS RESTRIÇÕES” ..................................................................... 59

2.4.1 O mínimo existencial ....................................................................................................... 62

2.4.2 O núcleo essencial e outras posições definitivas de direitos ........................................ 67

2.4.3 O princípio da máxima aplicação dos recursos ............................................................... 73

3 ASPECTOS JURÍDICOS ORÇAMENTÁRIOS DO PRINCÍPIO DA RESERVA DO

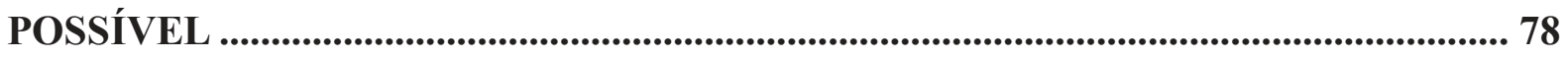

3.1 O PRINCÍPIO DA RESERVA DO POSSÍVEL E A ESCASSEZ DE RECURSOS ......... 80

3.1.1 A dimensão fática: escassez fática de recursos ou exaustão orçamentária.............. 81

3.1.2 A dimensão jurídica: a escassez de recursos e escolhas alocativas orçamentárias. 96 
3.1.2.1 As escolhas alocativas e a prioridade da proteção dos direitos fundamentais como ideia reguladora do sistema orçamentário. 98

$3.2 \mathrm{O}$ TRATAMENTO JURÍDICO-CONSTITUCIONAL DAS NORMAS ORÇAMENTÁRIAS. 104

3.3 O PRINCÍPIO DA RESERVA DO POSSÍVEL E OS DESVIOS DE PODER ORÇAMENTÁRIO. 113

4 A TEORIA DOS PRINCÍPIOS DE ROBERT ALEXY E A ANÁLISE DA RESERVA DO POSSÍVEL NA PONDERAÇÃO: UMA PROPOSTA DE CRITÉRIOS PARA ANÁliSE dA CONFIABILIDADE EPISTÊMICA DE PREMISSAS EMPÍRICAS E NORMATIVAS DO PRINCÍPIO. 112

4.1 RESERVA DO POSSÍVEL E A PONDERAÇÃO EPISTÊMICA 120

4.2 PARÂMETROS PARA ANÁLISE DA CONFIABILIDADE DA PREMISSA EMPÍRICA DO PRINCÍPIO DA RESERVA DO POSSÍVEL

4.2.1 Existência da prova documental suficiente à comprovação do impacto orçamentário e/ou da inexistência ou da insuficiência do crédito orçamentário para o atendimento da prestação do autor. 130

4.2.2 Possibilidade de utilização dos instrumentos de flexibilização orçamentária (como créditos especiais, créditos suplementares, transposição e remanejamentos) e da reserva de contingência. 135

4.2.3 Inexistência de violação dever jurídico ou desvios de poder orçamentário que ocasionaram a insuficiência do recurso público 140

4.3 PARÂMETROS PARA ANÁLISE DA CONFIABILIDADE DA PREMISSA NORMATIVA DO PRINCÍPIO DA RESERVA DO POSSÍVEL

4.3.1 A aplicação do princípio da reserva do possível não obsta a efetivação de prestações inseridas no mínimo existencial e outros direitos subjetivos reconhecidos pela ordem jurídica 144

4.3.2 Existência de decisão anterior vinculante do tribunal ou precedente judicial que tenha estabelecido regra de precedência do princípio da reserva do possível, nas mesmas condições, em relação ao mesmo princípio colidente. 146 
PARTE II - PESQUISA EMPÍRICA - PARÂMETROS DE CONFIABILIDADE EPISTÊMICA DO PRINCÍPIO DA RESERVA DO POSSÍVEL E A JURISPRUDÊNCIA DO STF E DO STJ.......................................................... 149

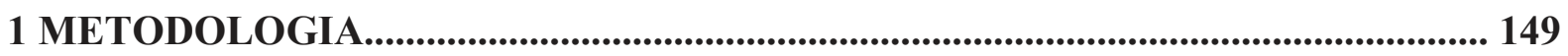

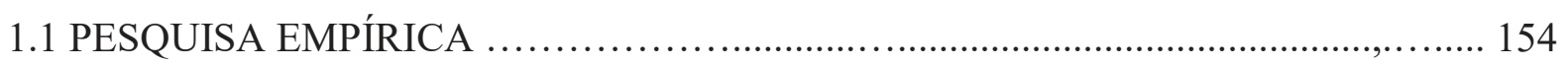

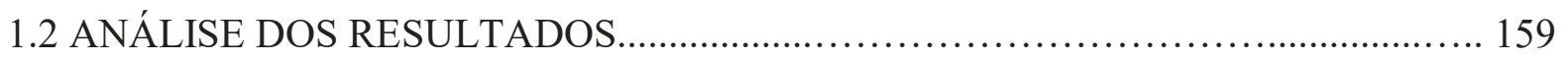

CONCLUSÃO

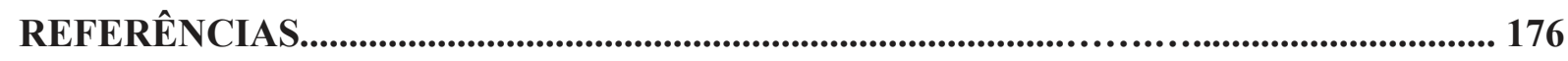

APÊNDICES....................................................................................................................... 190

APÊNDICE A - Ficha-Padrão para análise de decisões judiciais .................................... 190

APÊNDICE B - Quadros da tabulação cruzada quantitativa das decisões ................... 192

APÊNDICE C - Exemplos de fichas de análise de acórdãos no âmbito do STF............. 194

APÊNDICE D - Exemplos de fichas de análise de acórdãos no âmbito do STJ ......... 203 


\section{INTRODUÇÃO}

Diante do grave quadro de desigualdade e pobreza que ainda persiste em nosso país, paralelamente à dificuldade de acesso aos serviços públicos essenciais em níveis satisfatórios, inúmeras ações judiciais têm sido propostas na tentativa de garantir a efetivação de direitos constitucionalmente reconhecidos e, via de consequência, obstar a inércia ou a atuação defícitária da Administração Pública. A propositura dessas ações, em regra, objetiva a obtenção do cumprimento de obrigação de fazer, consistente em prestações materiais não ofertadas espontaneamente pelo Poder Público e, por consequência, o reconhecimento e a correção de eventuais omissões estatais na concretização dos direitos fundamentais a prestações fáticas.

O princípio da reserva do possível tem sido crescentemente utilizado no discurso de defesa apresentado pela Administração Pública nas ações em que figura como demandada e cujo pedido envolve a obtenção dessas prestações ${ }^{1}$. Constitui, ao lado do princípio da separação dos poderes, principal argumento a justificar a impossibilidade no atendimento das prestações materiais requeridas, tanto em matéria de direitos fundamentais sociais, quanto em relação a outras obrigações estatais que envolvam o dispêndio de recursos públicos.

A reflexão sobre o impacto do aumento de demandas individuais para a obtenção de prestações estatais na organização orçamentária estatal, principalmente no tocante àquelas concretizadoras do direito à saúde, tem sido objeto de inúmeras produções nas últimas décadas. No estudo recentemente publicado pelo Conselho Nacional de Justiça (CNJ), entitulado "Judicialização e saúde: ações para o acesso à saúde pública de qualidade"2, demonstra que o debate se divide entre aqueles "que defendem a judicialização da saúde como um mecanismo de ampliação da cidadania e da democracia e aqueles que a consideram um vetor de reprodução de desigualdades no acesso ao serviço de saúde" (BRASIL, CNJ, 2021, p. 15). Assim, se por um lado, a judicialização de demandas visando à efetivação de prestações materiais, principalmente aquelas inseridas no mínimo existencial, pode corrigir distorções na distribuição de bens e serviços públicos, sinalizando para a necessidade de reformulação de políticas públicas ineficientes, por outro, o deferimento de tais prestações

\footnotetext{
${ }^{1}$ Sobre a crescente utilização do argumento da escassez de recursos e da reserva do possível especificamente no âmbito das ações que demandam direitos à saúde, vide a pesquisa "Judicialização da saúde no Brasil: dados e experiência" (BRASIL, CNJ, 2015, p. 57).

2 Disponível em: https://www.cnj.jus.br/wp-content/uploads/2021/06/Relatorio_Judicializacao-e-Sociedade.pdf. Acesso em 12 jul. 2021.
} 
poderia potencializar a dificuldade da Administração Pública em assegurar a continuidade das políticas públicas já implementadas, diante de condenações judiciais que determinam a efetivação imediata dessas prestações, impactando diretamente na composição orçamentária. Nesse contexto, emerge o problema do equilíbrio entre as competências do Poder Judiciário e dos demais poderes que promovem originalmente as escolhas alocativas orçamentárias. Moreira (2011, p. 132) destaca que é neste cenário que a invocação da reserva do possível se torna ainda mais crítica e, muitas vezes, passa a destoar por completo do seu real sentido.

Ao introduzir em sua defesa processual o argumento da limitação orçamentária ao atendimento às prestações fáticas requeridas para a implementação de um direito fundamental, o Estado-Administração atrai para si o dever de provar suas alegações, consoante as regras processuais vigentes. Não havendo norma legal que autorize a presunção da escassez de recursos públicos, decorre que tal escassez, quando alegada pelo Poder Público como obstáculo à efetivação de uma prestação concretizadora de um direito fundamental, não é algo que deva ser tratado como uma presunção jurídica ou como fato notório ou autoevidente. Trata-se de fato jurídico que vai exigir prova de sua ocorrência e extensão, de acordo com a lei processual, em geral, a juntada das leis orçamentárias, anexos e estudos de impacto orçamentários. Ao mesmo tempo, nesses casos, acaba-se por transferir ao Poder Judiciário o encargo de avaliar, ainda que indiretamente, a constitucionalidade/conformidade das escolhas alocativas orçamentárias originariamente de competência do Poder Legislativo ou do Poder Executivo, na medida em tais escolhas possam implicam, em alguma medida, eventuais lesões aos direitos dos cidadãos.

O Poder Judiciário pode e deve cumprir a função que lhe foi constitucionalmente atribuída, de forma a equilibrar a imperiosa necessidade de garantir a progressiva concretização dos direitos fundamentais que o Estado brasileiro se comprometeu a promover desde a Constituição de 1988 e a atuação dos Poderes de forma harmônica e cooperativa entre si, nos limites de suas competências constitucionais. Não obstante, o problema que se levanta é: as decisões das cortes superiores brasileiras (STF e STJ), nas ações em que o princípio da reserva do possível é invocado pelo Poder Público, têm sido proferidas com fundamento em premissas suficientemente comprovadas e com grau adequado de confiabilidade epistêmica a ponto de justificar adequadamente intervenções em direitos fundamentais?

A hipótese levantada é que a abordagem do princípio da reserva do possível não tem ocorrido com a adoção de critérios técnicos suficientes para sua correta aplicação, sem a adequada comprovação de suas premissas, comprometendo a confiabilidade epistêmica de 
suas fundamentações. Essa situação pode acarretar tanto a concessão de prestações indevidas diante da ausência de prova ou da incerteza das alegações apresentadas por parte do Poder Público, quanto a denegação de prestações devidas e razoáveis, pelo apelo ao senso comum que paira sobre a presunção da escassez de recursos públicos para o atendimento das prestações materiais que concretizam direitos fundamentais de caráter prestacional. De igual modo, a ausência de critério também permite a proliferação de decisões contraditórias em situações semelhantes, em prejuízo da segurança jurídica e da isonomia no tratamento dos jurisdicionados.

O principal objetivo desta pesquisa é, portanto, aferir o grau de confiabilidade das premissas empíricas e normativas que fundamentam as decisões proferidas pelo Supremo Tribunal Federal (STF) e pelo Superior Tribunal de Justiça (STJ) nas ações em que o princípio da reserva do possível colide com normas que asseguram direitos fundamentais a prestações fáticas e constitui fundamento principal da solução da lide.

A pesquisa será elaborada em duas etapas: em um primeiro momento, a pesquisa teórica e, em um segundo momento, uma pesquisa empírico-documental exploratória das decisões destes tribunais. A metodologia utilizada na primeira parte dessa investigação consistirá em pesquisa do tipo bibliográfica, da qual se extrairão dedutivamente as bases conceituais do princípio da reserva do possível, de suas premissas empíricas e normativas, o contexto de sua aplicação quando em colisão com normas de direitos fundamentais. A pesquisa teórico-bibliográfica terá, pois, como objetivo principal a identificação de parâmetros objetivos para subsidiar a análise da confiabilidade epistêmica das premissas empíricas e normativas subjacentes ao princípio da reserva do possível, que possam auxiliar o intérprete a efetuar racionalmente a aplicação do princípio quando em colisão com normas de direitos fundamentais. Adotando a teoria dos princípios de Robert Alexy, marco teórico desta investigação, propõe-se a busca de parâmetros que possam ser utilizados na denominada fórmula do peso completa refinada, a qual considera, na ponderação, não somente os pesos das intervenções e o grau de exigência de satisfação dos princípios em colisão, mas também a medida da qualidade epistêmica com base na qual os pesos dessas intervenções são avaliados. Serão delimitados parâmetros para a análise da confiabilidade da premissa empírica (escassez de recursos públicos) e parâmetros para a análise da confiabilidade das premissas normativas.

Identificados os parâmetros, proceder-se-á à execução da pesquisa empíricodocumental, de natureza exploratória e qualitativa. A análise qualitativa visa à verificação do grau de confiabilidade epistêmica de premissas empíricas e normativas em que as decisões 
que envolvem o princípio da reserva do possível têm sido proferidas, variável dependente no estudo. Primeiramente, será efetuado o levantamento da frequência de ocorrência ou não dos parâmetros selecionados na pesquisa teórica na fundamentação das decisões do Supremo Tribunal Federal e do Superior Tribunal de Justiça, dentro do recorte temporal estipulado. Após o levantamento da frequência dos parâmetros estabelecidos, pretende-se realizar inferências sobre o grau de confiabilidade epistêmica empírica e normativa. A pesquisa poderá sofrer limitação quanto à verificação da confiabilidade epistêmica empírica, caso nem todas as peças processuais estejam disponíveis para a consulta on-line.

A justificativa para o recorte institucional reside no fato de que tanto o STF quanto o STJ abarcam em suas competências a função de uniformização da jurisprudência nacional, apresentando suas decisões efeito vinculante, nas hipóteses previstas na Constituição e na lei. Assim, a fundamentação dos acórdãos prolatados por esses tribunais possui grande relevância para o tema desta pesquisa, uma vez que servirá de orientação para os demais tribunais e juízes, em todo país, quando estiverem em discussão lides que envolvam conflitos entre o princípio da reserva do possível e princípios assecuratórios de direitos fundamentais.

A presente pesquisa se justifica porque a busca de critérios racionais e objetivos para o tratamento do princípio da reserva do possível e de suas premissas empíricas e normativas pode auxiliar o intérprete na correta aplicação do princípio da reserva do possível e apresenta inúmeras vantagens. Primeiro, inibe a invocação erística do instituto a partir de presunções não autorizadas por lei, principalmente em relação à escassez de recursos públicos que, como se defende, é fato a ser processualmente provado. Segundo, a adoção de critérios objetivos torna a utilização da ponderação mais tecnicamente adequada e contribui para evitar a prolação de sentenças impossíveis de serem executadas - que mitigam a credibilidade na força normativa da Constituição e das normas que veiculam direitos fundamentais. Terceiro, possibilita proteger posições de direitos fundamentais devidas que estão sendo violadas por uma omissão estatal, ao mesmo tempo em que protege outros interesses e direitos fundamentais de pretensões desarrazoadas. Quarto, possibilita atender às exigências de segurança jurídica e isonomia nas decisões judiciais. Na medida em que se apontam critérios decisórios objetivos relacionados ao princípio da reserva do possível e sua colisão com as normas de direitos fundamentais, contribui-se para a maior controlabilidade da fundamentação das decisões judiciais que dependam para a solução da lide a correta ponderação do princípio da reserva do possível e normas garantidoras de direitos fundamentais. 


\section{PARTE I - ELEMENTOS TEÓRICOS DO PRINCÍPIO DA RESERVA DO POSSÍVEL}

\section{O CONCEITO DO PRINCÍPIO DA RESERVA DO POSSÍVEL}

É condição necessária para o desenvolvimento de uma pesquisa a conceituação do objeto de sua análise. Embora amplamente recepcionado pela jurisprudência brasileira e doutrina pátria, inúmeras apropriações têm sido feitas sobre o tema "reserva do possível", o que torna a delimitação deste objeto uma tarefa mais complexa do que em relação a tópicos cujos conceitos já estão consolidados na doutrina. Por tal razão, neste capítulo inaugural, serão investigadas as origens do princípio da reserva do possível para a delimitação de seu conteúdo, e será proposto conceito apto a orientar a sua aplicação mais racional pelos tribunais brasileiros.

\subsection{O CONTEXTO JURÍDICO DE SURGIMENTO DA RESERVA DO POSSÍVEL}

O princípio da reserva do possível é um instituto jurídico cujo nascedouro ocorre externamente ao sistema jurídico-constitucional brasileiro. Para a melhor compreensão da racionalidade subjacente a essa construção jurídica, bem como para uma análise de sua importação e aplicação ao sistema jurídico-constitucional brasileiro, é importante o conhecimento dos fundamentos jurídicos que iniciaram essa discussão.

A noção de reserva do possível (Vorbehalt des Möglichen) tem sua origem comumente apontada pela doutrina constitucional nas decisões do Tribunal Constitucional alemão, sendo construção jurisprudencial iniciada, em especial, a partir do caso paradigmático denominado “decisão numerus clausus $I^{\text {”3 }}$ - BverfGE 33, 303, 1972 - ${ }^{4}$, que versava sobre o direito a vagas

3 Trata-se de uma expressão latina que significa "número fechado, ou taxativo" e que, no caso em análise, vai indicar critérios para a seleção dos candidatos que pretendem ingressar nas universidades públicas, com base em regras de desempenho.

4 De maneira diversa, Sgarbossa (2010, p. 128) aponta que, com base em dados históricos, que o fundamento da racionalidade da reserva do possível remonta ao Século VI, estampada no brocardo nec ultra vires ou secundum vires "de acordo com o qual as comunidades deveriam cuidar convenientemente de seus pobres na medida de suas forças, ficando a caridade, a filantropia e a assistência social condicionadas aos recursos disponíveis". Assim, observa o autor que o condicionamento da proteção social à disponibilidade de recursos provém de longa data. Por sua vez, o Ministro Humberto Martins afirmou em voto que "Na verdade, a tese da reserva do possível assenta-se em ideia que, desde os romanos, está incorporada na tradição ocidental, no sentido de que a obrigação impossível não pode ser exigida (Impossibilium nulla obligatio est - Celso, D. 50, 
em universidades. Ela foi invocada, posteriormente, em outros cinco casos de destaque (PERLINGEIRO, 2013, p.7; GAIER, 2011, p. 13).

$\mathrm{Na}$ decisão de 1972, o Tribunal Constitucional Federal alemão analisou a constitucionalidade de leis estaduais que instituíam critérios para o ingresso de estudantes nas Universidades de Hamburgo e da Baviera. O número de candidatos havia crescido em proporção maior do que a oferta de vagas. As leis estaduais foram editadas instituindo alguns parâmetros para a seleção dos candidatos - denominados numerus clausus ${ }^{5}$ - acarretando restrição ao acesso ao ensino superior. A constitucionalidade das respectivas leis foi questionada com base no direito à livre escolha de profissão e do local de formação, o qual era assegurado no art. 12 da Lei Fundamental (LF) alemã, de 1949 (SGARBOSSA, 2010, p. 134-135). Destaca-se um importante trecho da decisão:

\begin{abstract}
Mesmo na medida em que os direitos sociais de participação em benefícios estatais não são desde o início restringidos àquilo existente em cada caso, eles se encontram sob a reserva do possível, no sentido de estabelecer o que pode o indivíduo, racionalmente falando, exigir da coletividade. Isso deve ser avaliado em primeira linha pelo legislador em sua própria responsabilidade. Ele deve atender, na administração de seu orçamento, também a outros interesses da coletividade, considerando, conforme a prescrição expressa do Art. 109 II GG, as exigências da harmonização econômica geral. A ele compete também a decisão sobre a extensão e as prioridades da expansão do ensino superior, devendo se atentar para o fato de que ampliação e novas construções de instituições de ensino superior fazem parte, consoante o Art. 91a GG, das tarefas em prol da coletividade a serem cumpridas em atuação conjunta da União e dos Estados-membros. Junto a tais decisões, os órgãos estatais competentes deverão se orientar, de um lado, pelas reconhecíveis tendências de demanda por vagas no ensino superior, pois uma orientação exclusiva por investigações de necessidade, de qualquer forma difíceis de serem realizadas, poderia provocar direcionamento profissional e exame de necessidade não permitidos, e na qual restaria reduzido o significado da livre autodeterminação enquanto elemento constitutivo de um ordenamento de liberdade. Por outro lado, um tal mandamento constitucional não obriga, contudo, a prover a cada candidato, em qualquer momento, a vaga do ensino superior por ele desejada, tornando, desse modo, os dispendiosos investimentos na área do ensino superior dependentes exclusivamente da demanda individual frequentemente flutuante e influenciável por
\end{abstract}

17, 185). Não se pode exigir da ação humana a feitura de algo impossível" (BRASIL, STJ, Resp. 1.185.474/SC, 2010, p. 11).

5 Alinie da Matta Moreira (2011, p. 53) esclarece que o objeto do exame de constitucionalidade o chamado numerus clausus absoluto para calouros de determinada área de especialização, instituído em virtude do exaurimento de toda a capacidade de ensino. Não se trata das limitações locais e estruturais, que dificultam somente a escolha por uma determinada universidade, ou as limitações que atinjam apenas aos estudantes de semestres mais avançados já admitidos. A autora esclarece que: o "Numerus Clausus absoluto diferencia-se dessas limitações por seu efeito extremamente incisivo, pois ele faz com que um número maior ou menor dos candidatos tenham que adiar o início do curso desejado por um tempo mais ou menos longo. Em caso de forte demanda e correspondentes longos períodos de espera, tais limitações de admissão afetam não só a escolha dos locais de formação, como também podem influenciar na escolha profissional, provocando até mesmo o abandono das intenções originais. Candidatos socialmente mais carentes não têm as mesmas possibilidades, como os mais abastados, de passar por períodos mais longos de espera ou de tentar a realização de um curso no exterior" (MOREIRA, 2011, p. 53). 
variados fatores. Isso levaria a um entendimento errôneo da liberdade, junto ao qual teria sido ignorado que a liberdade pessoal, em longo prazo, não pode ser realizada alijada da capacidade funcional e do balanceamento do todo, e que o pensamento das pretensões subjetivas ilimitadas às custas da coletividade é incompatível com a ideia do Estado social (SCHWABE, 2005, p. 663-664).

O Tribunal Constitucional Federal alemão rejeitou a pretensão dos demandantes à criação imediata de novas vagas para o ingresso dos candidatos, não reconhecendo um direito subjetivo à uma vaga no ensino superior, mas ao direito de concorrer de forma isonômica à vaga $^{6}$. O tribunal reconheceu que a distribuição planificada tornar-se-ia inevitável após o esgotamento da totalidade da capacidade de formação. A decisão afirma que os "direitos de tomar parte" (Teilhaberechte) ${ }^{7}$ são limitados e não existentes a priori (SGARBOSSA, 2010, p. 136). Assim, segundo o acórdão “os direitos sociais de participação em benefícios estatais encontram-se sob a reserva do possível, que deve ser avaliada, em primeira instância pelo legislador e, em certa medida, tolerada pelo particular" (MOREIRA, 2011, p. 54). Para Perlingeiro (2013, p. 169), o argumento principal da decisão repousaria na ideia de "que o legislador, no exercício de suas atribuições, também deve observar outros interesses da comunidade". Seria, ainda, "uma incompreensão do significado de liberdade, se houvesse contínua precedência da liberdade pessoal em detrimento da capacidade funcional e do equilíbrio da sociedade como um todo" (PERLINGEIRO, 2013, p. 169).

Alinie da Matta Moreira (2011, p. 55) relata que o tribunal alemão reconheceu, entretanto, que a imposição de limitações absolutas para o ingresso de estudantes somente seria constitucional quando (1) fosse prescrito nos limites do estritamente necessário, sob a utilização exaustiva das capacidades criadas com recursos públicos já existentes de formação e quando (2) a escolha e a distribuição ocorrerem segundo critérios racionais, com uma

\footnotetext{
${ }^{6}$ Ingo W. Sarlet (2018), em artigo sobre o tema, relembra que em dezembro de 2017, o Tribunal Constitucional Federal Alemão voltou a analisar, em sede de controle concentrado de constitucionalidade, a correção dos critérios legais (e institucionais) de aferição da qualificação dos candidatos ao curso de medicina humana e/ou de outros requisitos para sua seleção. O autor esclarece que há diferença entre esta ação e a decisão no âmbito do BverfGE 33, 303 proferida no ano de 1.972. Na recente decisão, a ação não se tratava de reclamação constitucional (Verfassungsbeschwerde) interposta por um indivíduo que buscava o reconhecimento de um direito subjetivo fundamental originário, na condição de um direito a prestações estatais, de uma vaga no ensino superior, como corolário da liberdade de profissão, como ocorreu na decisão numerus clausus. Nessa oportunidade, o juízo de inconstitucionalidade proferido pelo tribunal centrou-se no devido processo substancial para uma seleção constitucionalmente adequada dos candidatos em condições isonômicas e compatíveis com o direito fundamental de liberdade profissional e de formação. Portanto, o autor ressalta que, no caso julgado em dezembro de 2018, também não se fizeram necessárias considerações acerca da reserva do possível (SARLET, 2018, p. 1). Por tal razão a decisão não é citada no texto da presente pesquisa.

7 Teilhaberechte em uma tradução livre significa direitos a ter uma igual cota-parte ou direitos de igual participação. No presente caso, remete à ideia de um direito de exigir do Estado uma prestação que garanta a participação do indivíduo na distribuição dos bens da sociedade.
} 
chance para todo candidato em si qualificado ao ensino superior e com o maior atendimento possível à escolha individual do local de formação. As limitações estabelecidas ao ingresso dos estudantes deveriam, portanto, ser proporcionais e objetivar a manutenção de um bom nível de ensino, proibindo a discriminação na admissão dos candidatos (SGARBOSSA, 2010, p. 136).

Ana Carolina Lopes Olsen (2006, p. 232), ao examinar o julgado do Tribunal Constitucional Federal alemão, identifica outro aspecto importante para o entendimento da fundamentação da decisão. Segundo Olsen:

[...] verificou-se que o Estado Alemão estava fazendo ou tinha feito tudo que estava ao seu alcance a fim de tornar o ensino superior acessível. Exigir mais, para o fim de satisfação individual de cada cidadão, obrigando o Estado a negligenciar outros programas sociais, ou mesmo comprometer suas políticas públicas, não se mostrava razoável (OLSEN, 2006, p. 232).

No caso apreciado, o Tribunal Constitucional Federal alemão não reconheceu o direito subjetivo à criação de novas vagas de forma imediata, uma vez constatado que o núcleo essencial do direito não tinha sido atingido pelas restrições estatais estabelecidas. Importante destacar que, na medida em que o tribunal reconheceu que o Estado Alemão envidou todos os esforços ao seu alcance para propiciar acesso ao ensino superior, verifica-se que o reconhecimento da exigência de razoabilidade da prestação pleiteada pelos autores das reclamações não se deu em um contexto de omissão estatal injustificada no atendimento às prestações relativas ao direito social pleiteado. Sgarbossa (2010, p. 138) chama a atenção para o fato de que esse estabelecimento de limites às demandas baseadas na cláusula do Estado Social pode ser entendido como "um teto do exigível". ${ }^{8}$ Entendeu-se que, naquele caso, não seria razoável comprometer outros bens jurídicos relevantes para o atendimento àquela demanda específica.

Olsen (2006, p. 233) destaca que essa teria sido a dimensão principal a ser extraída da

\footnotetext{
8 Importante para a reflexão sobre o papel da reserva do possível em estabelecer um "teto" às pretensões de prestações estatais sociais são as asserções de Andreas J. Krell que traz à tona uma importante indagação sobre quem possuiria “a legitimidade para definir o que seja 'o possível' na área das prestações sociais básicas face à composição distorcida dos orçamentos dos diferentes entes federativos". Para o autor os "problemas de exclusão social no Brasil de hoje se apresentam numa intensidade tão grave que não podem ser comparados à situação social dos países da União Europeia”. E prossegue: “A discussão europeia sobre os limites do Estado social e a redução de suas prestações e a contenção dos respectivos direitos subjetivos não pode absolutamente ser transferida para o Brasil, onde o Estado Providência nunca foi implantado" (KRELL, 2002, p. 53-54). Alguns autores questionam em que medida no Brasil esse "teto" pode ser estabelecido, uma vez que o mínimo sequer foi garantido, colocando em dúvida - e, com certa razão - se o princípio da reserva do possível poderia ser aplicado no contexto brasileiro.
} 
decisão que iniciou as discussões sobre a reserva do possível e não a questão financeira estatal, "no sentido de escassez absoluta de recursos" ". A autora fundamenta sua posição afirmando que:

\begin{abstract}
Mesmo que o Estado dispusesse dos recursos, segundo a reserva do possível instituída pelo tribunal alemão, não se poderia impor a ele uma obrigação que fugisse aos limites do razoável, tendo em vista os fins eleitos como relevantes pela Lei Fundamental. Não se poderia exigir o comprometimento de programas vinculados à satisfação de outros interesses fundamentalmente protegidos, para o fim de tornar o acesso ao ensino superior possível a absolutamente todos os indivíduos que assim o quisessem (OLSEN, 2006, p. 233).
\end{abstract}

Não obstante, a decisão acima ser considerada o paradigma para o entendimento da reserva do possível, não foi a única que tratou do tema no âmbito do Tribunal Constitucional Federal alemão. Em 1973, esse Tribunal decidiu outra lide que versava sobre a participação de diversos setores do ambiente universitário em órgãos colegiados das universidades, fazendo referência expressa ao precedente da decisão numerus clausus I - BVerfGE 33, 303 - e ao condicionamento dos direitos de participação (Teilhaberechte) à reserva do possível, novamente compreendida como o que se revela razoável o indivíduo esperar da sociedade. $\mathrm{O}$ contexto em que a decisão foi proferida estava marcado por uma tendência à hipertrofia das demandas dos cidadãos em face do Estado e, buscando limitá-la, o Tribunal se valeu novamente do recurso à razoabilidade, à proporcionalidade, à racionalidade como balizas dos referidos pleitos (SGARBOSSA, 2010, p. 141-142).

Em 1977, o Tribunal Constitucional Federal alemão julgou questão semelhante, precedente este alcunhado decisão numerus clausus II - BVerfGE 43, 291 -, no qual questionava-se a compatibilidade do art. 32, parágrafo $3^{\circ}$, item 1, alínea 6 , da Lei sobre o ensino superior com a Lei de Bonn, bem como a constitucionalidade da distribuição de vagas de estudos. Neste caso, foram tratados diversos aspectos dos referidos diplomas normativos regulamentadores das condições de acesso ao ensino superior, a exemplo da adoção de cotas para a seleção de candidatos. O Tribunal reiterou o entendimento do caso numerus clausus I (SGARBOSSA, 2010, p. 143).

Em 1990, o tema da "reserva do possível" voltou a ser tratado pelo Tribunal Constitucional Federal alemão para justificar a constitucionalidade da redução do auxílio-

\footnotetext{
${ }^{9}$ A mesma conclusão é enfatizada por Ingo Wolfgang Sarlet: “[...] mesmo dispondo o Estado de recursos e tendo o poder de disposição, não se pode falar em uma obrigação de prestar algo que não se mantenha nos limites do razoável" (SARLET, 2013, p. 29).
} 
criança para pais com nível de renda elevado ${ }^{10}$. Essa decisão introduziu um critério de aplicação da reserva do possível baseado na inadequação evidente de uma prestação devida constitucionalmente $^{11}$, bem como afirma que a prestação deve ser constitucionalmente adequada na "linha do tolerável", como condição para incidir a reserva do possível (PERLINGEIRO, 2013, p. 170).

Em 1992, o Tribunal analisou a possibilidade do tempo gasto na educação dos filhos ser considerado para o efeito de cálculo da aposentadoria, o que elevaria o benefício a um valor maior sem a correspondente contribuição ${ }^{12}$. Nesta decisão, a reserva do possível foi apontada "como um limitador de prestações que acarretem custos financeiros no âmbito dos incentivos públicos à família", o que não poderia ser aplicado somente se "a regra constitucional de incentivo, na prática, estivesse sendo violada por prestações 'evidentemente inadequadas' e fora do limite do tolerável, o que não era o caso" (PERLINGEIRO, 2013, p. 170).

Em outra decisão do ano de $1998^{13}$, discutiram-se também pretensões positivas estatais para proteção da família, mais especificamente, se as taxas que deveriam ser pagas pelos cuidados de crianças em jardins de infância poderiam ser escalonadas de acordo com a renda familiar e se o "Estado podia se recusar a subvencionar taxas de jardins de infância a pais abastados, mas que são garantidas às famílias mais pobres" (GAIER, 2013, p. 19). A decisão, inicialmente, destacou o princípio da igualdade de tratamento e examinou se o dever constitucional de incentivo em favor das famílias havia sido devidamente cumprido. A reserva do possível foi utilizada pelo Tribunal Constitucional Federal para fundamentar a conclusão de que "o dever de proteção não impede o Estado de diferenciar o valor da subvenção às famílias conforme sua carência financeira" e que o Estado não estaria "obrigado a compensar simplesmente todo encargo da família sem levar em consideração outros interesses públicos” (GAIER, 2013, p. 19).

\footnotetext{
${ }^{10}$ Vide julgado do Tribunal Constitucional Federal (BVerfG): 1 BvL 20/84. j. 29.05.1990. BVerfGE 82, 60. NJW 1990.

${ }^{11}$ Gaier esclarece que, embora carregado de indeterminação, o critério pode auxiliar a análise da reserva do possível pela jurisprudência ao estabelecer a ideia de que se "aquilo que o Estado efetivamente proporciona em virtude de uma obrigação decorrente da Constituição não for mais adequado, a Reserva do Possível não pode mais justificar essa limitação, pois assim a linha do tolerável é ultrapassada" (GAIER, 2013, p. 18).

${ }^{12}$ Vide julgado do Tribunal Constitucional Federal (BVerfG): 1 BvL 51/86; 50/87; 1 BvR 873/90, 761/91. j. 7 jul.1992, BVerfGE 87, 1. NJW 1992.

${ }^{13}$ Vide julgado do Tribunal Constitucional Federal (BVerfG): 1 BvR 178/97. j. 10 mar.1998; BVerfGE 97, 332. NJW 1998.
} 
Outra decisão foi proferida em $2001^{14}$ pelo Tribunal Constitucional Federal alemão e, dessa vez, a reserva do possível foi utilizada "para impor limitações às prestações fundadas na Constituição a um grau razoável” (GAIER, 2013, p. 19). Os autores da reclamação constitucional $^{15}$ pretendiam a isenção total de contribuição obrigatória paga por idosos necessitados. O pleito de isenção total da contribuição pretendida pelos reclamantes também foi improvido pelo Tribunal com base na reserva do possível. Entretanto, a partir da exegese do art. $6^{\circ}$, parágrafo $1^{\circ}$, da $\mathrm{LF}$, combinado com o art. $3^{\circ}$, parágrafo $1^{\circ}$, da $\mathrm{LF}$ (que trata da isonomia), reconheceu-se a obrigação de considerar a assistência e educação de filhos no cálculo das contribuições a serem pagas, acarretando uma contribuição mais reduzida em comparação aos segurados sem filhos. O raciocínio utilizado foi o de que mediante "o cuidado dos filhos por parte das famílias, além da contribuição financeira, é prestada uma 'contribuição para as futuras gerações' para manter, a longo prazo, a capacidade funcional dos Sistema de Seguridade Social" (GAIER, 2013, p. 19). O Tribunal considerou, ainda, que: a) o legislador teria de considerar, no interesse do bem comum, além do incentivo à família, outros interesses da comunidade; b) que somente na ponderação de todos os interesses seria possível averiguar se os incentivos à família por meio do Estado são evidentemente inadequados e não cumprem mais o mandamento constitucional de proteção. Foi também reconhecido que nessa situação conferia-se um poder discricionário ao Estado e que "seus limites não são ultrapassados, se famílias - isto é, cidadãos com filhos - forem onerados com contribuições para assistência social" (GAIER, 2013, p. 19).

Por último, destaca-se a decisão proferida no ano de $2004^{16}$, que tratou da lei que regulamentava o apoio e o auxílio do Estado aos viúvos ou viúvas das vítimas de crimes violentos, que cuidassem de um filho comum. Tal lei excluía do benefício os pais ou mães remanescentes de filhos "ilegítimos" da vítima, ainda que tivessem renunciado às suas atividades remuneradas e assumissem a assistência dos filhos comuns. Neste caso, o Tribunal Constitucional Federal considerou a lei inconstitucional, não por reconhecer um dever de prestação positiva, mas por violação ao princípio da igualdade. Afirmou-se que o legislador poderia, inclusive, revogar o benefício para todos os casos. A decisão reitera a posição de que o Estado não é obrigado a suportar todos os gravames financeiros do cônjuge remanescente,

14 Vide julgado do Tribunal Constitucional Federal (BVerfG): 1 BvR 1629/94. j. 3 abr. 2001, BVerfGE 103, 242. NJW 2001.

15 Verfassungsbeschwerde, literalmente traduzida como "reclamação constitucional", é uma ação constitucional proposta diretamente pelo indivíduo, em caso de possível ofensa a direitos constitucionais.

${ }^{16}$ Vide julgado do Tribunal Constitucional Federal (BVerfG): 1 BvR 684/98. j. 09.11.2004 e BVerfGE 112, 50. NJW, 2005. 
porque o órfão receberia uma pensão. Para o Tribunal, "o incentivo familiar estatal está, assim, sob a Reserva do Possível, tanto que, para o Estado, remanesce a discricionariedade para a forma e espécie de realização das compensações dos gastos familiares" (GAIER, 2013, p. 20).

Da análise das decisões acima, verifica-se que a jurisprudência do Tribunal Constitucional Federal alemão ora invocou a reserva do possível como fundamento para excluir totalmente uma determinada obrigação de prestação positiva estatal, ora para estabelecer limites para a prestação fornecida.

Nas decisões em que a reserva do possível foi invocada, a razoabilidade da pretensão individual foi questão preponderante, sendo a escassez de recursos considerada de forma secundária. Como visto, em alguns dos julgados, a análise da razoabilidade da prestação requerida foi abordada sob três aspectos a serem destacados, como: a adequação da prestação, a existência de uma linha do tolerável para exigir do Estado que arque com o custeio de prestações materiais, e a necessidade de se observarem outros interesses da sociedade.

Dos julgados acima, verifica-se que o princípio da reserva do possível, na forma como concebido pelo Tribunal Constitucional Federal da Alemanha, inaugura na jurisprudência a ideia de que há um limite ao que o particular pode exigir do Estado e da sociedade, principalmente quando a oferta da prestação comprometer outros interesses relevantes. Ao mesmo tempo, as decisões demonstram uma preocupação no sentido de verificar se o Estado estaria cumprindo satisfatoriamente seu dever de proteção e se o núcleo essencial do direito fundamental não estaria sendo atingido pelo excesso ou pela insuficiência da atuação estatal.

\subsection{O TRATAMENTO DA RESERVA DO POSSÍVEL NA JURISPRUDÊNCIA E NA DOUTRINA DO BRASIL}

No Brasil, a jurisprudência do Supremo Tribunal Federal inicia a abordagem do princípio da reserva do possível a partir de 2003, em decisão proferida em ação de intervenção federal ajuizada contra o Estado de São Paulo pelo não pagamento integral de precatório de natureza alimentar, requisitado em 1988, para inclusão no orçamento de $1989{ }^{17}$.

O princípio da reserva do possível tem sido cada vez mais inserido no discurso de defesa, apresentado pela Administração Pública perante os tribunais, como argumento a

17 Sobre as ações referentes a intervenção federal pelo não pagamento de precatórios, ver Daniel Welliang Wang (2013, p. 364-368). 
justificar uma omissão estatal, tanto em matéria de direitos fundamentais sociais, quanto em discussões sobre outras obrigações de fazer e de pagar. Pelos estudos de Daniel Welliang Wang (2013, p. 368) sobre a escassez de recursos, custos dos direitos e reserva do possível, na jurisprudência do STF, a reserva do possível é invocada em ações de diferentes naturezas, bem como é contraposta a direitos e a princípios de naturezas igualmente diversas, denotando a carência de uma abordagem mais técnica desse instituto jurídico.

O que chama a atenção, contudo, é que sua aplicação tem se dado de maneira diversa da que foi originalmente concebida pelo Tribunal Constitucional Federal alemão ${ }^{18}$. Na incorporação desse instituto no discurso da Administração Pública brasileira nas ações em que figura como parte requerida, observa-se o abandono da originária exigência de razoabilidade das prestações postuladas pelo particular em face do Estado, para dar centralidade ao aspecto da insuficiência/indisponibilidade de recursos públicos para o atendimento da prestação. Essa postura muda o enfoque da discussão nas ações propostas da razoabilidade da pretensão do particular, para a discussão da discricionariedade das decisões orçamentárias e, secundariamente, para a discussão das capacidades institucionais do Poder Judiciário para análise das políticas públicas, da violação ou não do princípio da separação dos poderes e da legitimidade democrática das decisões majoritárias ${ }^{19}$.

Destaca Ana Paula de Barcellos (2011, p. 279) que, na doutrina constitucional pátria, o tema reserva do possível começou a ter destaque a partir da década de 1990, tendo o debate se intensificado principalmente após a publicação por Stephen Holmes e Cass S. Sunstein de um estudo intitulado The Cost of Rights: Why Liberty Depends on Taxes (O custo dos direitos: por que a liberdade depende de impostos). Nessa obra, os autores realizam uma análise econômica dos custos dos direitos, demonstrando que não somente os direitos fundamentais sociais demandam consideráveis gastos estatais. A partir de então, para a autora, o tema reserva do possível tem sido associado não somente à problemática da efetividade e da

18 Conforme já visto, na jurisprudência do Tribunal Constitucional Federal alemão, a reserva do possível é expressamente concebida como aquilo que o indivíduo pode racionalmente esperar da sociedade. Essa também foi a ideia originária reproduzida na doutrina germânica (e.g. Robert Alexy e Konrad Hesse) de forma a estabelecer o alcance do "racionalmente concebível" aos direitos fundamentais sociais, de forma definitiva, baseado nos parâmetros da razoabilidade e da proporcionalidade. Secundariamente, é tratada a questão da escassez de recursos, levando-se em consideração o aumento da demanda pelos direitos fundamentais sociais e a necessidade de uma alocação equilibrada de recursos (SAGARBOSSA, 2010, p. 215-216).

19 Isso porque, como parte da doutrina argumenta, estando em causa a afetação de recursos públicos e diante da ausência ou insuficiência de critérios preestabelecidos pela Constituição, "o exercício dessa competência caberia aos órgãos políticos, sobretudo ao legislador, motivo pelo qual a realização dos direitos fundamentais sociais na condição de direitos subjetivos a prestações materiais implicaria sempre um problema de competências constitucionais, como expõe Gomes Canotilho" (SARLET, 2017, p. 613). 
exigibilidade dos direitos fundamentais sociais ${ }^{20}$, mas também à relação entre a escassez de recursos e escolhas trágicas (BARCELLOS, 2011, p. 279-281).

Por sua vez, Sarlet (2013, p. 29) assevera que a reserva do possível passou traduzir a ideia de que a efetividade dos direitos fundamentais sociais a prestações materiais dependeria da real disponibilidade de recursos financeiros por parte do Estado, a qual estaria localizada no âmbito discricionário das decisões governamentais e parlamentares, sintetizadas no orçamento público.

Andreas Joachim Krell adverte que, no Brasil, a doutrina assimilou a leitura que o professor português, J. J. Gomes Canotilho, fez da teoria alemã, apontando a dependência da efetivação dos direitos fundamentais sociais, econômicos e culturais aos recursos econômicos e que, segundo o autor

representa uma adaptação de um tópos da jurisprudência constitucional alemã (Der Vorbehalt des Möglichen), que entende que a construção de direitos subjetivos à prestação material de serviços públicos pelo Estado está sujeita à condição da disponibilidade dos respectivos recursos. Ao mesmo tempo, a decisão sobre a disponibilidade dos mesmos estaria localizada no campo discricionário das decisões governamentais e dos parlamentos, através da composição dos orçamentos públicos (KRELL, 2002, p. 51-52).

Vidal Serrano Nunes Júnior (2009, p. 176-177) e Andreas Joachim Krell (2002, p. 51) chamam a atenção para o cuidado na importação de teorias jurídicas desenvolvidas em países cuja realidade histórica e jurídica e, acima de tudo, sociocultural é diversa do Brasil.

Outro problema apontado, tanto por Sgarbossa (2010, p. 257), quanto por Olsen (2006, p. 364), é o caráter ideológico que o tema recebeu por parcela da doutrina que aborda a relação entre a reserva do possível e os direitos fundamentais sociais, pelo enfoque atribuído à escassez de recursos públicos e à primazia do aspecto econômico e orçamentário sobre o jurídico. Para os autores, posições como esta, trazidas por Gustavo Amaral e Flávio Galdino, implicam que as possibilidades fático-financeiras seriam condição da própria existência dos direitos fundamentais sociais ${ }^{21}$, podendo inclusive justificar a negativa de prestações situadas na esfera do mínimo existencial (SGARBOSSA, 2010, p. 206).

20 No mesmo sentido NUNES JÚNIOR (2009, p. 176-177).

21 Como exemplo, cita-se a posição de Flávio Galdino que é assim analisada por Sgarbossa: "é necessário observar que para Flávio Galdino os custos dos direitos não devem ser considerados simples óbices à concretização dos direitos, mas devem ser compreendidos, conforme já observado anteriormente, como constitutivos dos direitos. Assim, a afirmação da existência de um direito fundamental a priori é rechaçada pelo autor, sustentando este que 'impõe-se uma prévia análise de custo-benefício para compreenderem-se as consequências das escolhas” (SGARBOSSA, 2010, p. 206). 
Segundo Flávio Galdino

\begin{abstract}
Na medida em que o Estado é indispensável ao reconhecimento e efetivação dos direitos, e considerando que o Estado somente funciona em razão das contingências de recursos econômico-financeiros captadas junto ao indivíduos singularmente considerados, chega-se à conclusão de que os direitos só existem onde há fluxo orçamentário que o permita (GALDINO 2002, p. 188).
\end{abstract}

Como se verá em capítulo próprio, acredita-se que esse posicionamento não se sustenta $^{22}$. Essa corrente recebe inúmeras críticas, principalmente porque haveria uma sobreposição dos parâmetros econômicos sobre os jurídicos, enfraquecendo a tutela dos direitos prestacionais "na medida em que só seriam fundamentais os aspectos dos direitos que o Estado teria a possibilidade orçamentária de cumprir. O que não está no orçamento não seria fundamental" (MARTINS, 2020, p. 140). Ademais a afirmação de que o Estado somente funciona em razão de recursos captados junto aos indivíduos não condiz com a realidade brasileira, haja vista a pluralidade de instrumentos que o Estado brasileiro constitucionalmente e economicamente dispõe para angariar recursos para o custeio das prestações que deve concretizar, constituindo este argumento a adoção de uma teoria econômica específica como pressuposto limitador das capacidades estatais, a qual não é devidamente aclarada na fundamentação do raciocínio do autor, e não que deve ser tomada como dogma na seara do Direito. Esse tema será aprofundado em capítulo próprio.

O problema dessa posição é que, como assevera Olsen (2006, p. 191-192), "a escassez dos recursos econômicos destinados à realização destes direitos não é natural, essencial, mas artificial, fruto da escolha realizada pelos poderes públicos". A consequência que se extrai é que a fundamentalidade das normas garantidoras dos direitos em geral estaria submetida à discricionariedade das escolhas políticas e orçamentárias feitas pelos agentes políticos. E tais escolhas determinariam a normatividade dos direitos e não a força normativa dos direitos fundamentais orientaria as escolhas públicas. No entanto, conforme adverte Robert Alexy, os direitos a prestações, em virtude das normas de direitos fundamentais, "são, do ponto de vista do direito constitucional, tão importantes que a decisão sobre elas não pode ser simplesmente deixada para a maioria parlamentar simples" (ALEXY, 2015, p. 450). E, pode-se acrescentar, isso se aplicaria também ao "legislador orçamentário".

22 Olsen afirma: "Neste particular, verifica-se a forte influência exercida pela doutrina neoliberal, que pregando um "Estado mínimo" e gerando a ilusão de que apenas os direitos fundamentais sociais oneram o orçamento, procura enfraquecer o dirigismo constitucional" (OLSEN, 2006, p. 364). 
Tanto na jurisprudência (desde a decisão monocrática proferida na ADPF n ${ }^{\circ} 45 \mathrm{MC}$, da relatoria do Ministro Celso de Mello), como em parte da doutrina, há manifesta preocupação sobre a forma de aplicação da reserva do possível em nossa realidade e que pode ser bem representada pelo trecho abaixo:

Temos como certo que a reserva do possível não pode ser aceita como uma solução estrangeira para a falta de vontade política, a atuação deficitária do legislador e a desorganização do administrador público. Ela somente pode integrar a ordem jurídica brasileira quando for aplicada sem deturpação do seu real sentido e em consonância com a realidade que incide (MOREIRA, 2011, p. 57).

A par dessas considerações, a posição de Alinie da Matta Moreira (2011, p. 56) parece acertada. Sem negar as diferenças socioeconômica e jurídica existentes entre as realidades de Brasil e Alemanha, Moreira destaca que "estas disparidades" não constituem “óbice intransponível ao reconhecimento (sem distorções) e à aplicação do instituto [reserva do possível] no âmbito nacional". Isso se daria porque, segundo a autora, "o conflito central e originário, presente na teoria da reserva do possível - suficiência de recursos públicos versus implementação de prestações exigidas por particulares em face do Estado - é parte da realidade brasileira" (MOREIRA, 2011, p. 56).

É razoável afirmar que, na importação de institutos jurídicos alienígenas, é importante atentar-se para sua adaptação ao regime jurídico-constitucional do país em que pretendem ser aplicados, em observância à supremacia das normas constitucionais e à garantia de sua força normativa sobre todo o ordenamento jurídico. Essa análise pode-se dar em relação à forma de positivação dos direitos fundamentais no ordenamento, à identificação dos instrumentos de controle de constitucionalidade e de defesa processual dos direitos fundamentais assegurados (que vão interferir na delimitação das dimensões subjetivas e objetivas de cada direito), ao desenho jurídico-constitucional que define as atribuições funcionais e orçamentárias, e aos limites às funções atribuídas aos Poderes constituídos. Esses elementos vão influenciar os pressupostos jurídicos adotados por cada Estado e têm necessariamente que ser considerados.

A incorporação do princípio da reserva do possível ao sistema jurídico brasileiro como um argumento válido do Poder Público, no âmbito das ações judiciais que visem a compelir o Estado a cumprir obrigações de fazer positivas para a concretização de direitos prestacionais, não pode implicar a desconsideração das regras e dos princípios constitucionais que incidem sobre as questões jurídicas submetidas à apreciação dos Tribunais. Também não podem 
desconsiderar as regras processuais sobre o ônus da prova das alegações das partes, evitandose desse modo instituírem-se presunções não autorizadas por lei que trazem o regramento jurídico sobre a prova dos fatos relevantes alegados pelas partes, e que, portanto, devem orientar o julgador em suas decisões. Tecidas tais considerações, no próximo item pretende-se elaborar um conceito de reserva do possível que se compatibilize o sentido original do termo, calcado na jurisprudência alemã e a proteção dos direitos fundamentais no ordenamento constitucional brasileiro.

\subsection{O CONCEITO DE RESERVA DO POSSÍVEL}

O maior obstáculo para se conceituar a reserva do possível encontra-se na ausência de uniformidade de nomenclatura é tratado pela doutrina e pela jurisprudência, o que compromete a adequada compreensão de sua natureza jurídica e propicia o seu uso, por vezes, de forma atécnica nos tribunais brasileiros. Há inúmeras variações na terminologia adotada, sendo que algumas delas não convergem para a proposta da presente pesquisa. Encontramos referências à reserva do possível como uma cláusula, um postulado, um princípio, uma regra, ou, ainda, uma condição fática.

A variedade terminológica, quando se trata do tema "reserva do possível", é destacada por Mário Soares Caymmi Gomes:

Da análise acurada da bibliografia nacional, verificamos que o termo por vezes é usado sem nenhuma partícula determinadora antes dele, por outras é usado o artigo definido 'a'. Há também referências a um “discurso' (SIQUEIRA, 2010); a uma "cláusula" (VAZ, 2009; Min. CELSO DE MELLO, BRASIL, 2004); a uma "teoria" (SCAFF, 2005; AGUILAR; BOCCHI JR., 2011; REIS JÚNIOR, 2009; NAKAMURA, 2011; MÂNICA, 2007); e, finalmente, a um "princípio" (SILVA; WEIBLEN, 2007; Min. BENEDITO GONÇALVES, BRASIL, 2009). Ele também é tido como regra de distribuição do ônus da prova (vide Súmula 241 do TJRJ: “cabe ao ente público o ônus de demonstrar o atendimento à reserva do possível nas demandas que versem sobre efetivação de políticas públicas estabelecidas na Constituição"). Outros trabalhos dão ênfase na questão da reserva como instrumento de controle orçamentário (CARNEIRO FILHO, 2011; VAZ, 2009), adicionando um adjetivo ao seu nome ("reserva do financeiramente possível") (GOMES, 2013, p. 88).

Não há como exaurir o tema, ante a incomensurável "criatividade" dos juristas pátrios para designar a "reserva do possível". A proposta, portanto, é levantar as correntes doutrinárias mais relevantes para este trabalho e formular um conceito que seja compatível 
com a sua aplicação e a finalidade do instituto, em harmonia com as normas constitucionais e com a proteção dos direitos fundamentais.

Para iniciar a construção do conceito a ser adotado nesta pesquisa, são tomadas como ponto de partida as observações trazidas por Sarlet (2017, p. 613), o qual salienta que a reserva do possível é caracterizada por uma tríplice dimensão. Nas palavras do autor, a reserva do possível abrange:

(a) a real disponibilidade fática dos recursos para a efetivação dos direitos fundamentais sociais; (b) a disponibilidade jurídica dos recursos materiais e humanos, que guarda conexão com a distribuição das receitas e competências tributárias, orçamentárias, legislativas e administrativas, e, em países como o Brasil, ainda reclama um equacionamento em termos de sistema federativo; e (c) o problema da proporcionalidade da prestação, em especial quanto à sua exigibilidade e razoabilidade, no que concerne à perspectiva própria e peculiar do titular do direito (SARLET et al., 2017, p. 613-614).

Para Fernando Facury Scaff (2018, p. 296), a expressão reserva do possível desdobrase em diversas possibilidades relacionadas à ideia de escassez. A reserva do tecnicamente possível se caracterizaria como a impossibilidade concreta de sua realização, não por falta de dinheiro, mas por escassez decorrente da impossibilidade de produção de determinado bem em quantidade suficiente para o atendimento à sua demanda (escassez de escala industrial) ou decorrente do estágio da atual tecnologia ${ }^{23}$. Outro enfoque é a reserva do financeiramente possível liga-se à ideia de escassez de dinheiro. A "reserva do financeiramente possível encontra limitação nas disponibilidades orçamentárias, de arrecadação e de direcionamento da despesa pública" (SCAFF, 2018, p. 296-297).

Por sua vez, Barcellos (2011, p. 277) afirma que a expressão reserva do possível, de

23 Scaff ilustra em artigo escrito à revista eletrônica Conjur a situação decorrente da escassez de escala ou tecnológica com um exemplo real: "Um caso concreto pode ilustrar essa hipótese. A Universidade de São Paulo produzia determinado medicamento contra o câncer (fosfoetanolamina sintética), que ainda não havia sido liberado para produção industrial por falta de análise e registro na Anvisa. Logo, havia escassez do medicamento, pois sua produção se encontrava em fase de testes laboratoriais. Uma pessoa, sentindo-se preterida na obtenção do referido medicamento, ingressou com uma ação judicial contra a universidade e conseguiu liminarmente o direito de obtê-lo. Essa decisão foi cassada pelo Tribunal de Justiça de São Paulo, sob o argumento de grave risco à saúde, uma vez que o medicamento ainda não havia sido testado e aprovado pelas instâncias sanitárias nacionais. O caso chegou ao STF (Pet. 5.828) e foi relatado pelo ministro Edson Fachin, que suspendeu os efeitos da decisão do TJ-SP e liberou de imediato seu fornecimento. A partir daí centenas de outras ações semelhantes foram propostas,mas a escassez permaneceu, pois não havia medicamento produzido em escala suficiente para todos —além das questões sanitárias envolvidas. Trata-se de um caso de escassez, ou de reserva do tecnicamente possível. As liminares não puderam ser cumpridas de imediato em toda a sua extensão, pois somente muito tempo após é que se normalizou a produção de modo a atender àquilo que foi buscado e judicialmente deferido.” Disponível em: https://www.conjur.com.br/2018jan-23/contas-vista-vivemos-entre-reserva-possivel-escolhas-tragicas. Acesso em 9 jun.2020. 
maneira geral, refere-se ao "fenômeno econômico" da limitação dos recursos disponíveis diante das necessidades quase sempre infinitas a serem por eles supridas e que, para além das discussões jurídicas sobre o que se pode exigir judicialmente do Estado, haveria "um limite de possibilidades materiais para esses direitos". Afirma, ainda, que a expressão abarcaria duas espécies de fenômenos: o primeiro refere-se à inexistência absoluta de recursos ou exaustão orçamentária, o que denominou de reserva do possível fática; o segundo, caracteriza-se por uma ausência de autorização orçamentária para determinado gasto público, que denominou de reserva do possivel jurídica (BARCELLOS, 2011, p. 278).

Uma posição pouco difundida sobre a reserva do possível é a abordagem de Wálber Araújo Carneiro. O autor afirma que a reserva do possível não seria propriamente uma restrição a um direito, mas constituiria uma "excludente de ilicitude" em face de uma impossibilidade de conduta diversa por parte do Estado ante a escassez de recursos. Assim, “caberia ao Estado demonstrar essa escassez quando provocado a cumprir prestação de cunho social, prevista em norma constitucional" (CARNEIRO, 2004, p. 383). Afirmar que uma norma jurídica tem a natureza de justificante ou de excludente de ilicitude implica dizer que esta norma se trata de um tipo de norma permissiva, a qual especifica sob quais as circunstâncias uma conduta lesiva a um bem jurídico protegido não contraria a ordem jurídica e, por tal razão, não autoriza uma sanção jurídica.

Verifica-se que o conceito acima não se amolda à proposta deste trabalho. Primeiro, porque somente considera o aspecto econômico na análise da licitude da conduta estatal, desconsiderando sua formulação originária que se refere à razoabilidade da pretensão do particular perante a sociedade. Como já foi abordado, ainda que haja recursos, se constatada a ausência de razoabilidade da pretensão pleiteada, não se poderá atribuir ao Estado o dever de prestá-la (OLSEN, 2006, p. 233). Segundo, porque ao afirmar que a reserva do possível constituiria uma "excludente de ilicitude" em face de "uma impossibilidade de conduta diversa por parte do Estado ante a escassez de recursos", o autor incorre em equívoco técnico-jurídico, uma vez que a inexigibilidade de conduta diversa, em nosso ordenamento jurídico, não exclui a ilicitude da conduta do agente, mas a culpabilidade. Sob este fundamento, a conduta estatal de não atendimento à prestação material permaneceria ilícita, mesmo diante da escassez de recursos. Contudo, o agente não seria culpável por sua omissão. E permanecendo ilícita a conduta estatal, por força do artigo $37, \S 6^{\circ}$, da Constituição Federal que consagrou a responsabilidade objetiva estatal, poderia se autorizar inclusive a indenização do indivíduo pela violação de um bem jurídico protegido. Como se verá no decorrer desta 
pesquisa, esse entendimento não condiz com o tratamento que tem sido dispensado pela doutrina e pela jurisprudência pátria.

Ricardo Lobo Torres ao trazer a distinção entre o que denomina de "direitos sociais" dos "direitos fundamentais sociais" (identificando os últimos como compreendidos no mínimo existencial), afirma serem estes plenamente exigíveis, independentemente de atuação legislativa (TORRES, 2013, p. 73). Neste ponto, o autor distingue a reserva do possível daquilo que denomina reserva de orçamento. No primeiro caso trata-se necessidade "da reserva da lei instituidora das políticas públicas, da reserva da lei orçamentária e do empenho da despesa por parte da Administração" (TORRES, 2013, p. 74). No segundo caso, compreende a imprescindibilidade da existência da respectiva dotação orçamentária. A denominada reserva de orçamento seria aplicável mesmo nos casos de prestações referentes ao mínimo existencial e, neste caso, somente o legislador deve suprir as lacunas orçamentárias, destinando a respectiva dotação ao custeio das prestações de direitos fundamentais, através dos instrumentos orçamentários previstos na constituição (TORRES, 2013, p. 75). Assim, os direitos fundamentais sociais que integrassem a esfera do mínimo existencial excepcionariam a reserva do possível, mas não a reserva de orçamento. Em suas palavras:

\footnotetext{
Os direitos econômicos e sociais existem, portanto, sob a "reserva do possível" ou da "soberania orçamentária do legislador", ou seja, da reserva da lei instituidora das políticas públicas, da reserva da lei orçamentária e do empenho da despesa por parte da Administração. [...] Se não prevalece o princípio da reserva do possível sobre o direito fundamental ao mínimo existencial, nem por isso se pode fazer a ilação de que não deve ser observado o princípio da reserva do orçamento. A superação da omissão do legislador ou da lacuna orçamentária deve ser realizada por instrumentos orçamentários, e jamais à margem das regras constitucionais que regulam a lei de meios. Se, por absurdo, não houver dotação orçamentária, a abertura dos créditos adicionais cabe aos poderes políticos (Administração e Legislativo), e não ao Judiciário, que apenas reconhece a intangibilidade do mínimo existencial e determina os demais poderes a prática dos atos orçamentários cabíveis (TORRES, 2013, p.74-76).
}

A diferenciação entre reserva do possível e reserva orçamentária impõe uma limitação à efetividade dos direitos que compõem o mínimo existencial, mas é insuficiente para a conceituação da reserva do possível. Esta não se restringe à ideia de "soberania orçamentária do legislador", “à reserva da lei instituidora das políticas públicas, da reserva da lei orçamentária e do empenho da despesa por parte da Administração", consoante assevera o autor. Como se verifica, essa forma de conceituação também desconsidera a exigência de 
razoabilidade ínsita ao conceito originário da reserva do possível, bem como trazem como premissa a impossibilidade de se extraírem posições jurídicas subjetivas diretamente das normas constitucionais definidoras de direitos fundamentais, o que, de fato, é rechaçado pelo autor.

Por último, mas não de menor importância, destaca-se a posição de Olsen (2006, p. 211). Ao propor um conceito para a reserva do possível, a autora inicialmente esclarece que discorda de seu tratamento como "cláusula" ou "postulado", por não se tratar de uma "metanorma" 24 , uma vez que, para a autora, essas espécies não seriam passíveis de aplicação pela técnica da ponderação. Por outro lado, embora admita a possibilidade de ponderação da reserva do possível, a autora também nega sua natureza de norma jurídica, seja do tipo regra ou princípio, sob o seguinte argumento:

[...] parece inadequado conceber a reserva do possível como um princípio porque ela não prescreve um determinado estado de coisas a ser atingido, não corresponde a um mandado de otimização. Ainda que se admita a possibilidade de ponderação da reserva do possível, este elemento, por si só, não parece suficiente para identificá-la como um princípio, já que mesmo bens jurídicos podem ser ponderados. Em verdade, o que se pondera é a escassez de recursos apresentada pela reserva do possível, com o comando normativo do direito fundamental social (OLSEN, 2006, p. 211).

Afirma que a reserva do possível "é uma condição da realidade que determina a submissão dos direitos fundamentais prestacionais aos recursos existentes", como um elemento a eles externo (restrição). Por integrar uma realidade empírica, a autora adverte para as dificuldades de se "enquadrar um fenômeno em um conceito" (OLSEN, 2006, p. 225). Flávio Martins (2020, p.134), corroborando esse entendimento, assevera que "quando se analisa a reserva do possível, não se busca sua maior aplicabilidade, mas exatamente o contrário, visando minimizar seus impactos na eficácia dos direitos fundamentais sociais”.

\footnotetext{
${ }^{24}$ Postulado normativo são as normas que tratam de aplicação de outras normas. São espécies de metanormas que impõe um dever de segundo grau, consistente em estabelecer a estrutura de aplicação e prescrever modos de raciocínio ou argumentação em relação a outras normas. (PAULINO FILHO, Ronaldo. Espécies normativas: princípios, regras, meta-normas e interpretação constitucional. Boletim Jurídico. Ano XIX. n.999, mar.2020. Disponível em: <https://www.boletimjuridico.com.br/artigos/direito-constitucional/3960/especiesnormativas-principios-regras-meta-normas-interpretacao-constitucional $>$. Acesso em: 29 set. 2020). Flávio Martins esclarece que a expressão "postulado" na doutrina brasileira pode ser atribuída a Humberto Ávila, segundo o qual metanormas não prescrevem indiretamente um comportamento, mas "modos de raciocínio e argumentação relativamente a normas que indiretamente prescrevem comportamentos" (MARTINS, 2020, p. 135).
} 
Na mesma linha, cita-se o entendimento de Mário Soares Caymmi Gomes (2013, p. 92) que afirma que o tratamento mais equivocado à reserva do possível seria equipará-la a um princípio. E justifica:

Segundo Alexy (2008, p. 90), os princípios se caracterizam como um "mandamento de otimização" que deve ser realizado na maior medida possível dentro das possibilidades jurídicas e fáticas existentes no momento da aplicação. Assim, sendo, os elementos fáticos estão fora do campo do princípio e servem na verdade, como elemento de sua modulação (GOMES, 2013, p. 92).

Se adotarmos o entendimento dos autores acima, realmente não seria possível extrairse uma natureza principiológica, pela dificuldade em se defender a "otimização da escassez" e muito menos sua normatividade. Contudo, observa-se o equívoco dessa abordagem, na medida em que identificam e limitam o conceito da reserva do possível à dimensão fática da escassez de recursos, que nesta pesquisa se defende tratar-se de sua premissa empírica e não de seu conteúdo. Em outras palavras, a escassez não é o conteúdo a ser otimizado pela reserva do possível, como fazem entender os autores.

A par dessas considerações, para a melhor identificação do conceito e da natureza jurídica da reserva do possível, serão tomadas as lições de Robert Alexy sobre a norma jurídica, a fim de proporcionar uma homogeneização das nomenclaturas adotadas. Do ponto de vista qualitativo, Alexy (2015, p. 91) afirma que toda norma é ou uma regra ou um princípio $^{25}$. Princípios são mandamentos de um determinado tipo, a saber, mandamentos de otimização e, como mandamentos ou comandos, pertencem âmbito deontológico. Podem determinar a otimização de conteúdos (princípios materiais) ou, ainda, determinar a otimização de decisões (princípios formais).

Retomando as afirmações de Olsen, verifica-se que a autora, muito embora negue o caráter normativo da reserva do possível, atribui-lhe uma dupla dimensão, da seguinte forma:

[...] uma dimensão preponderantemente jurídica, de mandamento de realização dos direitos fundamentais sociais dentro de um padrão de razoabilidade e proporcionalidade, sob pena de ferimento do sistema constitucional como um todo, bem como uma dimensão especialmente fática, de mandamento de observância da realidade, da existência de recursos materiais e da exigência razoável e proporcional de alocação de recursos. Ainda, a reserva do possível acaba por determinar a ponderação entre o bem jurídico que se visa realizar e a escassez artificial de recursos, ou seja, aquela escassez que resulta da alocação dos recursos existentes para outros fins (OLSEN, 2006, p. 228).

\footnotetext{
${ }^{25}$ Nas palavras de Robert Alexy: "Isso significa que a distinção entre regras e princípios é uma distinção qualitativa e não uma distinção de grau. Toda norma é ou uma regra ou um princípio" (ALEXY, 2015, p. 91).
} 
É de se notar que, no tocante à dimensão jurídica da reserva do possível, a autora ressalta a existência de "mandamento de realização dos direitos fundamentais sociais dentro de um padrão de razoabilidade e proporcionalidade”. Por sua vez, em sua dimensão fática afirma ser "um mandamento de observância da realidade e da exigência razoável e proporcional da alocação de recursos”. Ora, a afirmação de que a reserva do possível constitui um mandamento, implica reconhecer que a mesma apresenta, sim, um caráter normativo, deôntico, veiculador de um comando (um dever ser), o qual é atributo de normas jurídicas e não da realidade empírica, como defende a autora. A realidade empírica se encontra no âmbito do ser e não do dever ser. A reserva do possível constitui, portanto, uma categoria jurídica e normativa, argumentativamente extraída de uma interpretação sistemática das normas constitucionais, veiculadora de um comando jurídico.

E do conteúdo desse mandamento, como expressa a autora, seria pouco provável extrair-se uma norma cuja natureza seja a de uma regra jurídica, uma vez que o seu objeto não possui densificação normativa suficiente para que seja aplicado diretamente por subsunção. Isso porque a exigência de observância da realidade e da exigência de razoável alocação de recursos implica a consideração de condições fáticas e jurídicas para a definição de seu conteúdo, que não estão pré-delimitadas no conteúdo do comando normativo, demandando a necessidade de ponderação. Exigir a aplicação mediante ponderação, enseja afirmar que seu conteúdo é passível de otimização, característica dos princípios jurídicos.

A partir de tais asserções, um conceito pode ser formulado, de forma a harmonizar a concepção originária do instituto e as dimensões apontadas por Sarlet e as consequências extraídas dessas dimensões por Olsen, com os devidos ajustes, uma vez que esta autora não atribui à reserva do possível a natureza de princípio. Na proposta desta pesquisa, a reserva do possível é, portanto, definida como um princípio jurídico que determina a razoabilidade tanto da pretensão (individual ou coletiva) de obtenção de prestações positivas materiais do Estado, relativas a posições jurídicas conferidas pelas normas de direitos fundamentais para além do seu núcleo essencial, quanto das alocações orçamentárias, em face da escassez (fática ou jurídica) comprovada e intransponível de recursos públicos.

Melhor esclarecendo o conceito. Enquanto princípio jurídico, a reserva do possível ordena a otimização do seu objeto: a razoabilidade, orientada tanto para o conteúdo da pretensão do particular (uma prestação positiva material do Estado), quanto para as escolhas 
alocativas dos recursos públicos. Essa exigência de razoabilidade direciona-se, portanto, tanto à conduta do cidadão, quanto à do Estado.

A razoabilidade pode ser entendida como uma medida de adequação e de harmonia/equilíbrio. Razoável é aquilo que se fundamenta em argumentos racionais, adequados e suficientes, para justificar uma ação, decorrente de uma deliberação tomada no exercício da razão prática. Essa ação, do ponto de vista do indivíduo, pode ser a busca de bens de vida (como prestações fáticas de direitos fundamentais) que podem propiciar o desenvolvimento de suas capacidades e assim gozar de uma existência digna, de forma equilibrada e harmonizada com as pretensões dos demais indivíduos e da sociedade ${ }^{26}$.

Sob a ótica estatal, razoáveis são normas que impliquem em restrições a direitos fundamentais cujas razões se demonstrem adequadas à consecução de uma finalidade assegurada pelas normas constitucionais. Nesse aspecto, Luis Roberto Barroso defende que a razoabilidade é baseada no devido processo legal substancial e pode-se identifica a existência de uma razoabilidade interna, no sentido de adequação de motivos, fins e dos meios quando da atuação do Estado na produção de normas jurídicas (BARROSO, 1997, p. 160) e de uma razoabilidade externa, na qual se verifica a adequação aos meios e fins admitidos e preconizados pelo texto constitucional.

O princípio da reserva do possível impõe que sejam fornecidas razões que demonstrem pelo lado das alocações orçamentárias que o montante de recursos destinados às despesas públicas é adequado ao atingimento de finalidades legítimas e constitucionalmente amparadas, que motivaram destinação dos recursos públicos. A exigência de razoabilidade nas decisões alocativas dos Poderes Representativos tem como parâmetro as prioridades constitucionalmente definidas.

Da natureza do conteúdo ou do objeto do princípio da reserva do possível, decorre sua

26 A definição proposta tem fundamento na conexão defendida por Victor Sales Pinheiro e Horácio Lopes Mousinho Neiva, entre a razão prática, Direito e bem comum. Ao analisarem a obra de John Finnis, os autores asseveram que "Na tomada de decisões concreta para realizá-los [os bens humanos básicos], surgem problemas de compatibilização com bens alheios, o que exige da razão prática a coordenação e conformação das ações individuais num plano de vida coerente. A coerência aqui não significa apenas autenticidade e coesão com a própria, na constituição de uma personalidade duradoura e estável, mas compatível com os planos de vida dos outros agentes racionais" (PINHEIRO; NEIVA, 2019, p. 254). Os autores afirmam, ainda, que "a razoabilidade prática tem uma dimensão pública e social, que é medida pela existência da autoridade do direito, que assegura o bem comum. Ora, não é arrazoado, nem do ponto de vista moral, nem jurídico, deixar-se vencer por paixões egoístas e impedir o florescimento humano das outras pessoas, igualmente dotadas de razoabilidade prática para estabelecerem suas prioridades morais num plano de vida" (PINHEIRO; NEIVA, 2019, p. 253). 
caracterização como princípio material ${ }^{27}$. Na ponderação, esse princípio poderá colidir isoladamente com outros princípios de direito fundamental ou associado a princípios formais, como o princípio do legislador democraticamente legitimado ou princípio da democracia ${ }^{28}$.

Como todo princípio jurídico, a reserva do possível é condicionada por possibilidades fáticas e jurídicas, que definem a ótima medida da realização de seu objeto. Como asseverado, as possibilidades fáticas são delimitadas pela comprovada e intransponível escassez de recursos públicos - em determinado tempo e espaço. Observa-se, pois, que a escassez de recursos públicos é uma premissa (ou uma condição necessária) que determina a otimização da exigência de razoabilidade tanto da pretensão quanto das alocações orçamentárias e não objeto de otimização do princípio da reserva do possível. Comprovada a escassez de recursos, há que se determinar um limite, não somente para a delimitação do conteúdo devido da prestação requerida do Poder Público, como também para determinar a organização das alocações orçamentárias. Isso porque uma pretensão razoável, extraída de posição prima facie de uma norma de direito fundamental, não pode se ver frustrada ou limitada por decisões alocativas irrazoavelmente tomadas pelo legislador ${ }^{29}$ ou pelo administrador público.

Por sua vez, as possibilidades jurídicas referem-se à necessidade de consideração da satisfação de princípio(s) jurídico(s) colidentes, no caso concreto (ALEXY, 2015, p. 90). Isso porque os princípios jurídicos, em abstrato, apresentam o mesmo grau de importância (peso) e convivem harmonicamente na ordem jurídica constitucional. Mas, no plano concreto, podem colidir como outros princípios, desempenhando um papel restritivo na determinação do âmbito da proteção definitiva de outro princípio ou direito. Isso se dá porque nenhum direito ou princípio é absoluto, inatingível por qualquer restrição. Dessa forma, o princípio da reserva do possível contribui para a delimitação do conteúdo do direito fundamental definitivamente devido ao particular, ao mesmo tempo em que fornece razões adequadas para a proteção do

27 Robert Alexy apresenta uma categorização dos princípios em duas naturezas: os denominados princípios materiais e os principios formais. Considerando que ambos são mandamentos de otimização, a principal diferença entre essas categorias de princípios está no objeto da otimização. O objeto de otimização dos princípios materiais são conteúdos como a vida, a proteção ao meio ambiente e a liberdade de expressão. Já os princípios formais exigem a otimização da autoridade de decisões tomadas no âmbito de competências, veiculadas através de normas jurídicas expedidas em conformidade com o ordenamento jurídico e socialmente eficazes, referindo-se, neste caso à dimensão fática do direito (ALEXY, 2018, p. 10).

28 Segundo Alexy, o princípio da democracia exige que "o legislador democraticamente legitimado tome tantas decisões importantes para a sociedade quanto possível". Com essa exigência, o princípio da democracia se refere não só à autoridade das decisões tomadas dentro do escopo das competências parlamentares, como requer que esse escopo seja o mais amplo possível (ALEXY, 2018, p. 10).

29 Ada Pellegrini Grinover defende que "o julgador apreciará, pelo lado do autor, a razoabilidade da pretensão individual/social deduzida em face do Poder Público e, por parte do Poder Público, se a escolha do agente público foi desarrazoada" (GRIONVER, 2010, p. 23). 
conteúdo das prestações já efetivadas e asseguradas pelas leis orçamentárias.

A máxima da proporcionalidade constitui técnica destinada a extrair a máxima efetividade de princípios em colisão, na medida em que possibilita otimizar o conteúdo desses princípios frente às possibilidade fáticas e jurídicas que se extraem das premissas que fundamentarão a decisão judicial. Tais possibilidades podem variar no tempo e no espaço. Cumpre salientar as observações feitas por Virgílio Afonso da Silva (2002, p. 33), em esclarecedor artigo sobre o tema, que ressalta a diferença entre aquilo que é "razoável" e o que é "proporcional", asseverando que "o conceito de razoabilidade, na forma como exposto, corresponde apenas à primeira das três sub-regras da proporcionalidade, isto é , apenas à exigência de adequação" (SILVA, 2002, p. 33). Assim, a utilização da máxima da proporcionalidade na solução de colisões que envolvam o princípio da reserva do possível, além do exame da adequação entre meios e fins, vai impor o atendimento às submáximas da necessidade e da proporcionalidade em sentido estrito, mais adiante explicitadas.

Dessa forma, pode-se afirmar que em uma colisão do princípio da reserva do possível com uma norma de direito constitucional que assegure um direito fundamental, a utilização da máxima da proporcionalidade pode extrair a otimização/maximização do conteúdo destas normas, frente à necessidade do atendimento de outros interesses da coletividade. A proporcionalidade vai exigir, além da demonstração, no caso concreto, de adequação da prestação pleiteada pelo particular (razoabilidade) e da adequação da alocação orçamentária, que seja demonstrada que a prestação pleiteada e a forma de alocação escolhida pelo legislador são necessárias. Neste último caso, são necessárias as alocações destinadas a prestações adequadas ao atingimento das prioridades constitucionais, com a eleição de meios mais ou igualmente eficazes e menos onerosos dentre os disponíveis. Por fim, que a decisão alocativa deve ser proporcional (em sentido estrito), possibilitando demonstrar o emprego dos recursos disponíveis e possíveis foram efetuados prioritariamente nas áreas que concretizam direitos fundamentais constitucionalmente mais relevantes em relação a outras despesas não essenciais previstas no orçamento. Há que se justificar o não atendimento da prestação requerida pelo particular ao Poder Público pela demonstração da maior importância de satisfação de outras prestações ou direitos fundamentais que seriam inequívoca e mais gravemente prejudicados pelo atendimento da prestação pleiteada.

O conceito proposto converge com a preocupação do Tribunal Constitucional Federal alemão, o qual enfatiza a consideração da proteção de outros interesses igualmente relevantes. Isso porque, em alguns casos, os recursos materiais e financeiros podem ser faticamente 
existentes, mas a sua "alocação em determinados setores acaba por implicar o não atendimento de outras necessidades, por uma decisão disjuntiva do órgão ou agente com competência em matéria alocativa" (SGARBOSSA, 2010, p. 220). A consideração da importância de se efetivarem outros interesses e princípios resguardados na ordem constitucional e da insuficiência dos recursos para efetivar tal tarefa, de forma imediata e simultânea, delimitará o grau de otimização da razoabilidade da pretensão e das alocações orçamentárias, exigíveis pelo princípio da reserva do possível. Os elementos do conceito acima expostos serão aprofundados no desenvolvimento dos capítulos seguintes. 


\section{OS DIREITOS FUNDAMENTAIS E O PRINCÍPIO DA RESERVA DO POSSÍVEL}

Após a delimitação conceitual do objeto desta pesquisa, passa-se a analisar a relação entre o princípio da reserva do possível e os direitos fundamentais em sua dimensão positiva. Em regra, na doutrina, o princípio da reserva do possível vem majoritariamente associado à problemática da efetividade das normas de direitos fundamentais sociais. Isso se explica porque, como já visto, a reflexão sobre o instituto jurídico emergiu, com maior ênfase, a partir de decisões do Tribunal Constitucional Federal alemão no âmbito de ações que demandavam a efetivação de prestações relacionadas aos direitos fundamentais sociais.

Contudo, como será explicitado neste capítulo, essa relação está presente no âmbito de todos direitos fundamentais que, em alguma medida, exigem do Estado prestações estatais positivas. Por tal razão o argumento econômico e, consequentemente, o princípio da reserva do possível, não é fundamento suficiente para impor restrições às prestações somente relacionadas aos direitos fundamentais sociais, atribuindo-lhes tratamento diferenciado dos demais direitos fundamentais. Para melhor compreensão do proposto, uma sucinta digressão sobre a constitucionalização dos direitos fundamentais é necessária. Ainda, serão analisadas a teoria do custo dos direitos fundamentais, a partir das considerações feitas por Stephen Holmes e Cass S. Sunstein, a teoria das restrições aos direitos fundamentais e a teoria das "restrições às restrições".

\subsection{A CONSTITUCIONALIZAÇÃO DOS DIREITOS FUNDAMENTAIS}

O reconhecimento e institucionalização da normatividade de direitos atribuídos ao indivíduo fazem parte de um processo civilizatório, fruto da realidade histórico-social e que, aos poucos, também foi transformando a modelagem dos Estados, de suas funções e de seus fins, orientando sua organização e a forma de atuação na sociedade. Esses direitos reconhecidos à pessoa humana, quando positivados nas Constituições dos diversos países, foram denominados de direitos fundamentais e dirigem normativamente a atuação estatal e seus fins.

Os direitos fundamentais são posições jurídicas reconhecidas e protegidas no ordenamento jurídico-constitucional interno de cada país (SARLET, 2017, p. 321). A fundamentalidade do direito, entretanto, não depende exclusivamente de sua positivação, pois, como é o caso da própria Constituição de 1988, há a previsão expressa (BRASIL, 1988, art. 
$5^{\circ}, \S 2^{\circ}$ ) da possibilidade de reconhecimento de outros direitos fundamentais não previstos no catálogo do Título II, além de posições implícitas que podem ser extraídas do texto constitucional.

Como esclarece Robert Alexy (2017, p. 522), quando se trata da característica de fundamentalidade dos direitos, verifica-se que, "o significado das normas de direitos fundamentais para o sistema jurídico é o resultado da soma de dois fatores: da sua fundamentalidade formal e da sua fundamentalidade substancial". A fundamentalidade formal decorre da sua posição no ápice do ordenamento jurídico, vinculando tanto o legislador, quanto o Poder Executivo e o Judiciário. À fundamentalidade formal é somada a fundamentalidade substancial, pois, com tais direitos e normas "são tomadas decisões sobre a estrutura básica do Estado e da sociedade", desempenhando "um papel central no sistema jurídico".

Conforme destaca Sarlet (2017, p. 321-322), no Brasil, as normas de direitos fundamentais contam com uma disciplina jurídica diferenciada das normas infraconstitucionais e também em relação a outras normas da Constituição. Primeiramente, extraem seu regime jurídico a partir da própria constituição, que se relaciona à sua fundamentalidade formal. Apresentam, pois, uma posição hierárquica superior no ordenamento jurídico submetendo-se a limites formais e protegidas na condição de limites materiais ao poder constituinte derivado (BRASIL, 1988, art. 60, $\S 4^{\circ}$, inc. IV). De forma mais específica, o autor destaca que são normas diretamente aplicáveis, demonstrando uma força jurídica privilegiada, que vinculam de forma imediata os Poderes e os atores privados (BRASIL, 1988, art. $5^{\circ}, \S 1^{\circ}$ ). Mais adiante, afirmam que a característica de aplicabilidade direta, imputada às normas de direitos fundamentais, tem como consequências, dentre outras, a extração de um “dever de maximização (otimização) da eficácia e efetividade” dessas normas, bem como a exclusão de um caráter meramente programático, porquanto não podem ser reduzidas à condição de normas destituídas de qualquer eficácia ou aplicabilidade (SARLET, 2017, p. 373).

Sob a ótica de sua fundamentalidade material, Sarlet (2017, p. 322) afirma que os direitos fundamentais veiculam conteúdos ou decisões fundamentais sobre a estrutura do Estado e da sociedade, no tocante à posição que é ocupada nestes pela pessoa humana. Neste ponto, as normas que veiculam direitos fundamentais individuais e as que veiculam direitos fundamentais sociais não se diferenciam. Estas não seriam menos fundamentais em termos 
formais ou substanciais por veicularem direitos a prestações positivas ${ }^{30}$, principalmente porque constituem pressupostos imprescindíveis ao exercício da autodeterminação e da dignidade do indivíduo.

$\mathrm{Na}$ esteira de Robert Alexy que afirma a fundamentalidade formal e material das normas de direitos fundamentais, Sarlet (2017, p. 323) formula um conceito de direitos fundamentais da seguinte forma

[...] é possível definir direitos fundamentais como todas as posições jurídicas concernentes às pessoas (naturais ou jurídicas, consideradas na perspectiva individual ou transindividual) que, do ponto de vista do direito constitucional positivo, forma, expressa ou implicitamente, integradas à constituição e retiradas da esfera de disponibilidade dos poderes constituídos, bem como todas as posições jurídicas que, por seu conteúdo e significado, possam lhes ser equiparadas, tendo, ou não assento na constituição formal (SARLET, 2017, p. 323).

Inicialmente, os primeiros direitos fundamentais incorporados nas Constituições escritas apresentavam um caráter individualista. Seu reconhecimento e incorporação nos ordenamentos jurídico-constitucionais dos Estados remontam ao século XVIII. Sob a égide do pensamento liberal-burguês, buscavam essencialmente garantir uma "esfera de autonomia individual em face de seu poder" (SARLET, 2017, p. 314).

No final do século XIX, inicia-se uma nova fase de institucionalização de direitos fundamentais. $\mathrm{O}$ advento da industrialização acarretou graves problemas sociais e econômicos, intensificando a exclusão social. Movimentos reivindicatórios pelo reconhecimento de direitos que assegurassem condições de igualdade no exercício da cidadania impulsionaram um papel ativo do Estado na realização da justiça social e da igualdade material (SARLET, 2017, p. 315).

Uma das características marcantes do constitucionalismo que emergiu no pós-segunda guerra foi a incorporação, nas Constituições de diversos países ocidentais, de uma gama de direitos que incidem sobre a ordem social, cultural e econômica. Inicialmente, essa categoria de direitos foi assegurada em pactos internacionais e em legislações infraconstitucionais, mas ao longo do século $\mathrm{XX}$, passa a ser incorporada nos ordenamentos jurídicos em normas constitucionais. Como exemplo, destacam-se: a Constituição Mexicana de 1917; a

30 Corroborando esse entendimento, Robert Alexy vai formular o seguinte enunciado geral sobre os direitos a prestações: "Em virtude de normas de direitos fundamentais, todos encontram-se em posições de direitos a prestações que são, do ponto de vista do direito constitucional, tão importantes que a decisão sobre elas não posa ser simplesmente deixada para a maioria parlamentar simples" (ALEXY, 2015, p. 450). 
Constituição de Weimar de 1919; a Constituição italiana de 1947; a Constituição alemã de 1949; a Constituição portuguesa de 1976; a Constituição espanhola de 1978 e a Constituição brasileira de 1988 (SGARBOSSA, 2010, p. 58-59).

A proteção que o Estado deve fornecer aos direitos fundamentais, a partir de então, exige o arranjo de novas funções, antes adstritas à observância de deveres e limites negativos impostos pelas liberdades formais abstratas. Ao Estado cabe também implementar ações positivas que possibilitem assegurar as condições materiais necessárias à garantia de uma existência digna aos indivíduos, e que são determinantes, inclusive, para o exercício dos direitos ou liberdades "clássicas". Os denominados direitos fundamentais sociais têm, portanto, uma dimensão positiva marcante, eis que, para a sua tutela, é exigida do Estado a adoção de medidas para propiciar "um direito de participar do bem-estar social", mediante prestações fáticas a exemplo da assistência social, saúde, educação, proteção ao trabalho, dentre outros (SARLET, 2017, p. 315).

O reconhecimento dessa nova categoria de direitos acarretou substancial modificação na compreensão dos deveres estatais. Ao tratar do que denominou de princípio do estado social na Lei Fundamental alemã, Konrad Hesse descreve a mudança de paradigma dos deveres estatais frente aos direitos fundamentais sociais da seguinte forma:

b) Se, em vista dessa situação, a Lei Fundamental qualifica o Estado por ela constituído, como um 'estado de direito social', então isso significa não só um reconhecimento forçado de uma realidade que não mais pode ser negada. Senão, isso significa que as tarefas do Estado não mais se esgotam na proteção, conservação, só ocasionalmente, intervenção. O Estado da Lei Fundamental é Estado que planifica, guia, presta, distribui, possibilita primeiro a vida individual como social e isso é posto para ele, pela fórmula do estado de direito social, por causa da Constituição, como tarefa. Essa tarefa fundamenta não só uma 'obrigação social' da coletividade diante de seus membros, portanto, a obrigação para assistência social, assistência vital e satisfação social, mas também obrigações sociais dos membros da coletividade entre si, assim como diante da coletividade [...] (HESSE, 1998, p. 175).

Há, portanto, uma reorientação na forma de proteção dos direitos fundamentais e das funções estatais para além da exigência de garantia da igualdade em sentido formal, característica do Estado Liberal, transcendendo para uma exigência de garantia também da igualdade material entre os indivíduos. Nesse sentido é a posição de Alexy, ao discorrer a favor da importância dos direitos fundamentais sociais como garantidores de uma liberdade 
fática ou real ${ }^{31}$.

Altera-se, pois, a configuração do Estado de Direito para um Estado de Direito Social que se organizou em diversas molduras. Não obstante o seu reconhecimento nas Constituições de diversos países, essa categoria de direitos trouxe problemas jurídicos novos e significativos no que se refere à garantia de sua efetividade (SGARBOSSA, 2010, p. 42).

Uma das primeiras distorções que se foi consolidando, e até certo ponto, foi naturalizada, é a distinção no tratamento dos direitos fundamentais individuais e políticos em relação aos direitos fundamentais sociais. De maneira geral, sob a ótica da atuação estatal, a doutrina atribuía aos direitos reconhecidos a partir do Estado Liberal um caráter "negativo", sob o argumento de que, para a proteção desses direitos, bastaria mera abstenção estatal. Ao contrário, os direitos fundamentais sociais teriam um caráter "positivo" na medida em que sempre exigem uma ação estatal material. Passou-se a atribuir aos direitos fundamentais sociais o estigma de serem direitos mais "custosos", porque demandariam, para sua efetivação, inúmeras prestações positivas estatais, ao contrário dos direitos a liberdades, os quais não exigiriam tais prestações da sociedade e do Estado. Essa posição é influenciada pela teoria do status elaborada por Jellinek ${ }^{32}$ (MARTINS, 2020, p. 210).

Em decorrência da abordagem proposta por Jellinek, bem como da cisão no sistema de proteção dos direitos humanos, ocorrida por ocasião da Assembleia Geral das Nações Unidas de 1951, sob a influência da doutrina que apregoava a progressividade ou a implantação progressiva dos direitos fundamentais sociais (SGARBOSSA, 2010, p. 129), consolidou-se uma posição dicotômica na abordagem dos direitos fundamentais individuais e dos direitos sociais, principalmente no tocante à sua eficácia e fundamentalidade ${ }^{33}$. Essa distinção teve impacto no reconhecimento do alcance e na justiciabilidade dos direitos fundamentais, prestigiando os direitos fundamentais individuais (MARTINS, 2020, p. 210) e tem relação com o princípio da reserva do possível, uma vez que este foi costumeiramente

\footnotetext{
${ }^{31} \mathrm{O}$ autor sustenta que "a liberdade jurídica, isto é, a permissão jurídica de se fazer ou deixar de fazer algo, não tem valor sem uma liberdade fática (real), isto é, a possibilidade fática de escolher entre as alternativas permitidas. Mais adiante ele cita a posição de Lorenz von Stein: "A liberdade é real apenas para aquele que tem as condições para exercê-la, os bens materiais e intelectuais que são pressupostos da autodeterminação" (ALEXY, 2015, p. 503-504).

32 Alexy $(2015$, p. 255) ao analisar a teoria elaborada por Georg Jellinek, destaca que o autor diferenciava quatro status: passivo, negativo, positivo e o ativo. Nesse sentido, status seria uma situação, uma forma de relação entre cidadão e Estado, e tem como conteúdo o "ser", o que, consequentemente, difere de um direito.

33 Essa diferenciação fica clara na seguinte afirmação: "Vê-se, pois, que, se a emergência dos direitos fundamentais sociais modificou a equação liberdade/igualdade e deu novo colorido à temática da justiça social, nem por isso transferiu a lógica e as garantias dos direitos da liberdade para os sociais, nem metamorfoseou os direitos fundamentais sociais em autênticos direitos fundamentais" (TORRES, 1989, p. $34)$.
} 
tratado pela doutrina e pela jurisprudência como uma das restrições à efetivação somente dos direitos fundamentais sociais.

Mais recentemente, essa dicotomia começou a se enfraquecer pelos equívocos de seus fundamentos, revelando mais um caráter ideológico do que técnico na abordagem dos direitos fundamentais sociais, tendo naturalizado essa diferenciação, como adiante será analisado.

\subsection{O CARÁTER PRESTACIONAL DOS DIREITOS FUNDAMENTAIS E OS CUSTOS DOS DIREITOS}

Como visto, tradicionalmente, a doutrina tem dispensado tratamento diferenciado entre os direitos fundamentais individuais dos direitos fundamentais sociais. Martins aponta algumas características que impediriam a equiparação dessas categorias de direitos, mitigando os direitos fundamentais sociais no plano de sua eficácia, de sua vinculatividade jurídica e, consequentemente, de sua justiciabilidade. São elas:

a) o fato de os direitos sociais valerem sob reserva do (financeiramente) possível; b) o fato de os direitos sociais apresentarem uma estrutura de direitos positivos; e c) a indeterminabilidade do conteúdo constitucional dos direitos sociais". Além dessas diferenças, Martins (2020, p.110) acrescenta outras, apontadas pela doutrina: “d) maior onerosidade dos direitos sociais; e) a titularidade setorial dos direitos sociais (MARTINS, 2020, p. 109-110).

Das características acima, a primeira merece uma análise mais detalhada por sua pertinência ao tema desta pesquisa. Verifica-, se que três dos pontos acima estão intimamente relacionados com o princípio da reserva do possível, podendo ser resumidos no seguinte argumento: os direitos fundamentais sociais, enquanto direitos positivos, demandam prestações fáticas estatais e, consequentemente, um aporte substancial de recursos públicos, implicando maior onerosidade em sua efetivação. Consequentemente, apenas os direitos fundamentais sociais estariam sujeitos à restringibilidade imposta pelo princípio da reserva do possível. Ao contrário, os direitos fundamentais individuais, em razão de possuírem a natureza de direitos de defesa, demandariam apenas uma abstenção estatal, não ensejando qualquer custo ao Estado.

Como dito, a pretensa dicotomia entre os direitos fundamentais individuais e os direitos fundamentais sociais tem origem no sistema apresentado por George Jellinek. Contudo, o fundamento dessa diferenciação passou a sofrer críticas. A primeira se refere ao 
fato de que a teoria do status "não comportaria o reconhecimento de direitos sociais com características típicas de direitos de defesa" (MOREIRA, 2011, p. 39), o que não condiz com a realidade. A doutrina brasileira passou a reconhecer que, em certa medida, os direitos fundamentais sociais também demandam prestações negativas, como o caso do direito de greve, da liberdade sindical e de outros direitos fundamentais sociais, que, além da oferta de serviços públicos, exigem o dever estatal de não privar os cidadãos do acesso àquele direito ou o dever de não anular tal direito (MARTINS, 2020, p. 209).

Passou-se a reconhecer, portanto, que todos os direitos fundamentais, sejam eles mais ou menos densificados nas respectivas Constituições, exigem mais do que uma postura meramente negativa do Estado. Assim, os direitos fundamentais sociais contam com dupla dimensão: positiva e negativa. Matthias Klatt sintetiza de forma esclarecedora a questão:

\begin{abstract}
Aceita-se, atualmente, que é infrutífera toda e qualquer tentativa de limitar a dimensão positiva de certos tipos ou categorias de direitos. Ao invés, todos os direitos, literalmente, podem impor obrigações positivas e negativas às autoridades. Com isso, o status positivus - no sentido atribuído pela doutrina de Georg Jellinek tem aplicabilidade potencial bastante ampla. Sabe-se também que a dimensão positiva dos direitos é frequentemente mais debatida no âmbito dos direitos sociais e socioeconômicos, tais como educação, saúde, moradia e água. Contudo, a dimensão positiva não se restringe, de forma alguma, aos direitos sociais. Na verdade, todos os direitos liberais clássicos de primeira geração também têm uma dimensão positiva, ao passo que os direitos sociais e socioeconômicos também têm um status negativus. Assim, os direitos civis ou liberais não podem ser considerados diferentes dos direitos socioeconômicos a partir da dicotomia positivo-negativa (KLATT, 2015, p. 217).
\end{abstract}

Alexy afirma que a classificação de Jellinek seria insuficiente e formula a base da teoria analítica dos direitos a partir de "uma tríplice divisão das posições que devem ser designadas como 'direitos' em (1) direitos a algo, (2) liberdades ${ }^{34}$ e (3) competências ${ }^{35 \text { ", }}$

\footnotetext{
${ }^{34}$ Alexy (2015, p. 232-234) faz uma diferenciação entre liberdades não protegidas e liberdades protegidas. As primeiras são identificadas como permissões de fazer algo ou de se abster de fazê-lo as quais não exigem normas e direitos garantidores desta liberdade, o que não implica sua desproteção. A proteção constitucional da liberdade é constituída por um feixe de direitos a algo e também por normas objetivas e que garantem ao titular do direito fundamental a possibilidade de realizar a ação permitida. Assim, se uma liberdade está associada a um direito ou norma, ela será uma liberdade protegida. Uma proteção positiva de uma liberdade em face do Estado surge da combinação de uma liberdade com um direito a uma ação positiva, tornando faticamente possível ao portador da liberdade aquilo que a ele é permitido e, nesse sentido, juridicamente possível.

${ }^{35}$ A terceira modalidade de direito se referem às competências que se refere à capacidade de ação do indivíduo e que, por natureza, não possui, pois é conferida pelo ordenamento jurídico. As competências vão se diferenciar das permissões que nada adiciona à capacidade de ação do indivíduo, existindo independentemente dela e sem alteração da situação jurídica. Também competência não se confunde com a capacidade fática. Uma competência é uma posição criada por uma norma de competência que possibilita a um sujeito alterar a posição jurídica de outro sujeito de direito, sem a necessidade de ações de outros sujeitos. Assim, uma competência do cidadão pode ser protegida no âmbito dos direitos fundamentais e o legislador que revogasse essa competência
} 
(ALEXY, 2015, p. 193). No caso dos direitos a algo, dois objetos podem ser identificados: ações negativas (abstenção) e ações positivas (um fazer). No âmbito dos direitos em face do Estado, os direitos a ações negativas correspondem aos chamados direitos de defesa ${ }^{36}$. Os direitos a uma ação positiva identificam-se parcialmente com o que é chamado de "direitos a prestações" (ALEXY, 2015, p. 195-196). Por sua vez, os direitos a ações positivas dividem-se em dois grupos de acordo com o seu objeto. Podem ser direitos a uma ação normativa ou direitos a uma ação fática. Direitos a ações positivas normativas são direitos a atos estatais de criação de normas. $\mathrm{O}$ autor afirma que as ações positivas fáticas ou prestações em sentido estrito, constituem ações que também poderiam ser prestadas por particulares, ao contrário dos direitos à ação normativa. A diferenciação entre elas é justamente que, no caso da ação positiva fática é indiferente para a satisfação do direito de que forma ela ocorre (ALEXY, 2015, p. 202).

A escala de ações estatais positivas que podem ser objeto de um direito à prestação estende-se desde a proteção do cidadão contra outros cidadãos, passa pelo estabelecimento de normas organizacionais e procedimentais e alcança até prestações em espécie ou em outros bens (ALEXY, 2015, p. 442). Assim, aprofundando sua análise, Alexy subdivide os direitos a ações estatais positivas em: (1) direitos à proteção; (2) direitos à organização e procedimento e (3) direitos à prestação em sentido estrito (que identifica com os direitos fundamentais sociais $)^{37}$. O jusfilósofo alemão demonstra que um direito fundamental completo consiste num feixe de ações definitivas e prima facie, de diferentes conteúdos, relacionadas entre si por meio de três perspectivas que são atribuídas a uma disposição de direito fundamental. ${ }^{38}$ Esse conceito de direito fundamental completo valeria tanto para os direitos fundamentais sociais quanto para os direitos fundamentais individuais.

Nessa linha, Baptista e Silva (2018, p. 197) afirmam que todos os direitos exigem do

violaria uma norma de direito fundamental. Isso porque o não-reconhecimento ou a eliminação de uma competência é um obstáculo à liberdade jurídica de realizar ou não um ato jurídico (ex. casamento). Em relação às competências do Estado as normas de direitos fundamentais atuam como normas negativas de competência, correspondendo a uma proibição dirigida ao ente estatal de agir. (ALEXY, 2015, p. 235-248).

${ }^{36}$ Alexy (2015, p. 196-201) classifica os direitos a ações negativas em: direitos ao não-embaraço de ações, direitos à não-afetação de características e situações e direitos à não-eliminação de posições jurídicas.

${ }^{37}$ Especificamente em relação aos direitos fundamentais sociais, Alexy afirma que estes são considerados direitos a prestação por excelência. Pela amplitude e complexidade da classificação proposta por Alexy, o corte temático se limitará ao esclarecimento das ações positivas, que compõe os direitos a algo e que se relacionam às situações em que a reserva do possível tem sido utilizada como argumento para exonerar o Estado do dever de concretizar direitos a prestações. Por ora, será suficiente o entendimento dessa classificação, deixando de abordar as liberdades e as competências.

38 "As normas e posições pode ser divididas em três perspectivas: (1) de acordo com posições no sistema de posições jurídicas fundamentais; (2) segundo o grau de generalidade e (3) segundo se trate de posições com caráter de regra ou de princípio" (ALEXY, 2015, p. 251). 
Estado, simultaneamente, atitudes de (1) respeito (ou seja, abstenção de agressão), (2) de proteção (contra terceiros) e (3) um esforço de realização que dê concretização ou efetividade prática aos mesmos. Essas dimensões dos direitos pressupõem a existência e manutenção de um vasto conjunto de custosas instituições, donde decorre que todos os direitos fundamentais exigem a ação positiva do Estado. Os autores asseveram:

\begin{abstract}
E por isso mesmo que todos os direitos são simultaneamente "negativos" e "positivos" e que todos têm custos substanciais: custos orçamentais e custos em termos da limitação que impõem a realização de outros direitos, princípios ou valores constitucionalmente relevantes. Dai também que todos os direitos, e não apenas os sociais, estejam sujeitos a "reserva do financeiramente possível". Neste sentido, a única diferença entre os direitos sociais e os de liberdade proviria da naturalização destes (e das suas "densificações" infraconstitucionais e modos de realização ou institucionalização material) que leva à "indivisibilidade" dos custos que lhes estão associados (BAPTISTA e SILVA, 2018, p. 197).
\end{abstract}

Essa posição também é sustentada por Sarlet (2017, p. 604) que afirma a dupla dimensão - negativa (defensiva) e positiva (prestacional) dos direitos fundamentais sociais. Para o autor, as normas de direitos fundamentais sociais abrangem "um leque diferenciado de posições jurídico-subjetivas que podem estar vinculadas a um mesmo direito fundamental (social) compreendido em sentido amplo" (SARLET, 2017, p. 604). Sarlet esclarece ainda que, embora "habitualmente referidos ao princípio da igualdade na sua vertente substantiva", os direitos fundamentais sociais não se limitam à função de direitos que garantem somente prestações materiais. Dessa forma, "também para os direitos fundamentais sociais vale a premissa de que todos os direitos fundamentais apresentam uma perspectiva (ou dimensão) positiva e negativa". Os direitos fundamentais sociais, na condição de direitos subjetivos, operam tanto como direitos de defesa quanto como direitos a prestações, podendo ser tanto direitos a prestações fáticas, quanto direitos a prestações normativas, de caráter organizatório e procedimental (SARLET, 2017a, p. 604-605).

Uma observação incumbe ser feita. Embora o marco teórico adotado nesta pesquisa seja a teoria de Robert Alexy, para a conceituação de direitos fundamentais sociais na ótica constitucional brasileira, entende-se insuficiente a proposta trazida por este renomado jusfilósofo, uma vez que este identifica os direitos fundamentais sociais somente como direitos a prestação em sentido estrito, consistente em "direitos do indivíduo em face do Estado, a algo que o indivíduo, se dispusesse de meios financeiros suficientes, poderia obter de particulares" (ALEXY, 2017, p. 499). Assim, o conceito defendido Sarlet (2017a, p. 604) 
parece se adequar mais ao ordenamento jurídico-constitucional brasileiro e à proposta doutrinária que defende que todas as categorias de direitos implicam ações positivas e negativas, ao mesmo tempo, incluindo prestações normativas. Ademais, não se pode afirmar que os direitos fundamentais sociais, no Brasil, serão somente garantidos àqueles que não possuem recursos para obtê-los, implicando uma seletividade econômica, a exemplo do que ocorre com o direito à saúde e à educação cuja prestação é direito de todos, não se fazendo acepção de classe econômica.

O dever atribuído ao Estado de ofertar tais prestações reafirma a opção constitucional de autorizar a intervenção estatal no domínio econômico, não sendo necessariamente obtidas de particulares. Ademais, em regra, não há como o Estado ofertar prestações materiais sem uma estrutura normativa e organizacional que viabilize faticamente a entrega dessas prestações, sendo destas dependentes, assim, como os direitos fundamentais individuais e políticos. Assim, harmoniza-se a ideia de direito fundamental social com o que Alexy afirma ser um direito fundamental completo e afasta a noção de que os direitos fundamentais sociais somente se restringem à garantia de prestações positivas fáticas.

O raciocínio que induz a afirmações no sentido de que os direitos fundamentais sociais seriam sempre "mais custosos" que os demais constitui um posicionamento equivocado. Embora o próprio Alexy (2017, p. 510) afirme categoricamente que "todos os direitos fundamentais sociais são extremamente custosos", isso não significa necessariamente que os direitos fundamentais sociais serem "mais custosos" do que outras categorias de direitos fundamentais ou que os demais direitos fundamentais não exijam qualquer custo do Estado para sua proteção.

Quando se afirma a existência de uma eficácia horizontal dos direitos fundamentais fica mais difícil ainda sustentar que mera abstenção estatal é suficiente para a tutela de direitos fundamentais individuais, como os direitos à vida, à propriedade ou à liberdade. Isso porque, a necessidade de se garantir a observância dos direitos fundamentais entre os próprios particulares implica necessariamente e, no mínimo, a organização de uma jurisdição que possa apreciar as lesões ou ameaças a lesões aos direitos fundamentais, a exemplo do que ocorre com o habeas corpus, que também pode ser impetrado contra ato de particular que ameace a liberdade individual.

Segundo a classificação proposta por Alexy (2015, p. 433), todos os direitos que 
exigem uma ação estatal positiva podem ser tidos como direitos a prestações ${ }^{39}$, e neles se incluem algumas posições jurídicas exigidas também pelos direito fundamentais individuais. Assim, é insustentável uma distinção entre os direitos fundamentais sociais e os demais direitos fundamentais pelo mero argumento de que aqueles apresentariam um status positivo, enquanto os direitos fundamentais individuais apresentam um status negativo ou de defesa. É inegável que os direitos fundamentais individuais também demandam prestações estatais positivas, as quais, invariavelmente, têm um custo para a sociedade, muito embora essas restrições não sejam costumeiramente invocadas nas demandas que discutem direitos fundamentais individuais - e.g.: a carência de juízes e oficiais de justiça não é questionada ante a pretensão da concessão de um habeas corpus que garante a liberdade de locomoção (SARLET, 2017a, p. 612).

Uma segunda e importante objeção ao posicionamento da doutrina tradicional, que defende a dicotomia entre os direitos fundamentais sociais e direitos fundamentais individuais e que enfatiza o caráter prestacional somente daqueles direitos, começa a ser difundida principalmente a partir publicação por Stephen Holmes e Cass S. Sunstein de seu estudo The Cost of Rights: Why Liberty Depends on Taxes, no qual são analisados aspectos jurídicos e econômicos dos custos dos direitos de forma geral. Nessa obra, os autores demonstram, com vários exemplos, que a distinção entre direitos positivos e direitos negativos encontra-se superada, uma vez que todos os direitos impõem ao Estado obrigações de fazer (ações) e de não fazer (abstenções), em maior ou menor intensidade. Nas palavras dos autores:

Isto é, a liberdade pessoal não pode ser assegurada pela mera limitação da ingerência
do Estado mediante as liberdades de ação e associação. Não há direito algum que se
resuma ao direito de ser deixado em paz pelos agentes públicos; todos os direitos
implicam uma pretensão a uma resposta afirmativa por parte do Estado. [...] Todos
os direitos custam caro, porque todos eles pressupõem que o contribuinte financie
um mecanismo eficiente de supervisão, que monitore o exercício dos direitos e o
imponha quando necessário. [...] O financiamento de direitos básicos por meio da
renda tributária nos ajuda a ver claramente que os direitos são bens públicos:
serviços sociais pagos pelo contribuinte e administrados pelo governo, cujo objetivo

\footnotetext{
${ }^{39}$ Segundo o autor, pela ótica da interpretação liberal clássica, direitos fundamentais são “'destinados, em primeira instância, a proteger a esfera de liberdade do indivíduo contra intervenções dos Poderes Públicos; eles são direitos de defesa do cidadão contra o Estado'. Direitos de defesa do cidadão contra o Estado são direitos a ações negativas (abstenções) do Estado. Eles pertencem ao status negativo, mais precisamente ao status negativo em sentido amplo. Seu contraponto são os direitos a uma ação positiva do Estado, que pertencem ao status positivo, mais precisamente ao status positivo em sentido estrito. Se se adota um conceito amplo de prestação, todos os direitos a uma ação estatal positiva podem ser classificados como direitos a prestações estatais em um sentido mais amplo; de forma abreviada: como direitos a prestações em sentido amplo" (Ibidem, p. 433).
} 
é aperfeiçoar o bem-estar coletivo e individual. Todos os direitos são positivos (HOLMES; SUNSTEIN, 2019, posição 479-603).

Ricardo Lobo Torres afirma que o próprio Jellinek já observava que a garantia jurisdicional constituía o status positivus da liberdade e que o Estado, ao lado da prestação jurisdicional, deve garantir também positivamente as liberdades através da polícia, das forças armadas, entre outros. Para o autor, os "direitos fundamentais, em suma, são garantidos pelos serviços públicos e por isso mesmo lhes constituem o fundamento" (TORRES, 1989, p. 39).

No mesmo sentido, estão as asserções de Martins:

\begin{abstract}
Outrossim, para garantia dos direitos fundamentais individuais, negativos ou liberdades públicas, existe um aparato judicial bastante oneroso: "com o advento da modernidade, tornou-se claro que a eficaz proteção da generalidade dos direitos e liberdades fundamentais passa pela existência de um aparelho judiciário com os recursos necessários para funcionar de forma célere e independente, e de autoridades policiais munidas de toda uma logística que implica avultados custos". Dessa maneira, como afirma Gerardo Pisarello, "todos os direitos fundamentais podem caracterizar-se como pretensões híbridas frente ao poder: positivas e negativas, em parte custosas e em parte não custosas" (MARTINS, 2020, p. 113).
\end{abstract}

Portanto, a exigibilidade dos direitos fundamentais sociais não poderia ser mitigada pelo acolhimento do argumento econômico da escassez de recursos, de forma irrefletida. Se o custo é fator mitigador da exigibilidade de um direito fundamental, seria, então, questionável invocar-se o princípio da reserva do possível somente no âmbito de ações em que se discute a implementação de direitos fundamentais sociais. Não há razões jurídicas, nem econômicas, para que se imponha ao juiz considerar os custos para o fornecimento de um medicamento para a garantia do direito à saúde ou para o a disponibilização de vaga em escola pública para o exercício do direito à educação e não fazer a mesma exigência para que o juiz considere os custos da manutenção de um indivíduo no cárcere - principalmente depois de reconhecido o estado de coisas inconstitucional do sistema carcerário brasileiro, violador de direitos fundamentais. Essa análise, no momento da apreciação de um pedido de revogação de uma prisão preventiva ou da apreciação de um habeas corpus, se justifica para resguardar de indevidas violações os direitos fundamentais (como a liberdade e a saúde) do indivíduo decorrentes da submissão a um tratamento desumano e degradante decorrente da insuficiência de recursos estatais para estruturar de forma adequada os estabelecimentos prisionais, que origina excesso juridicamente não autorizado na execução de uma medida constritiva da 
liberdade de locomoção.

Como ilustração da assertiva de que o fator econômico pode ser preponderante também no resguardo dos direitos fundamenetais individuais (mais até do que em relação a um direito fundamental social), pode-se citar o levantamento do Tribunal de Contas da União (TCU) analisado no acórdão proferido nos autos do Relatório de Auditoria (RA) $\mathrm{n}^{\mathrm{o}}$ 018.047/2018-1 (BRASIL, TCU, 2019), da relatoria da Ministra Ana Arraes, o qual apontou que, um preso custaria aos cofres públicos, na apuração global dos Estados avaliados, cerca de R\$ 22.948,00 por ano, sendo que, especificamente, para o Estado de Minas Gerais esse valor perfazia a quantia estimada de $\mathrm{R} \$ 36.015,00$. O mesmo relatório demonstra que o custo referência para criação de novas vagas perfaz o montante de $\mathrm{R} \$ 49.350,00$. Esse valor seria o necessário para garantir a observância dos parâmetros mínimos de infraestrutura estabelecidos na Lei $n^{0}$ 7.210/1984 (Lei de Execução Penal) e obstar violações ao direito à liberdade decorrente do excesso na execução de uma pena em condições subumanas. Para efeito de comparação, em 2017, o Ministério da Educação definiu para o Fundo de Desenvolvimento da Educação Básica (FUNDEB) o custo anual mínimo por aluno de R\$ 2.875,03 ${ }^{40}$.

Ora, se há escassez de recursos públicos e, por tal razão, o fator custo for tão preponderante na efetivação e proteção dos direitos fundamentais, numa análise objetiva e consequencialista, com ênfase no aspecto econômico - que tem sido exigida dos julgadores na efetivação dos direitos fundamentais sociais -, muito mais deveria ser exigido do juiz que o princípio da reserva do possível fosse considerado na concessão de um habeas corpus nestas situações. Isso porque, como asseverado, o custo da manutenção de um indivíduo no cárcere demanda dos cofres públicos mais do que 10 vezes mais o valor da manutenção de um aluno nas escolas públicas ou, eventualmente, similar ao custo de um medicamento fornecido pelo Sistema Único de Saúde a cada cidadão. Não há, pois, sob a ótica do custo, razões suficientes para um atribuir um tratamento mitigador exclusivamente em relação à exigibilidade dos direitos fundamentais sociais. O fundamento econômico-orçamentário não é apto a sustentar, por si só, que somente os direitos fundamentais sociais "valeriam sob a reserva do (financeiramente) possível", conforme apontado por Martins. Sob esse aspecto, qualquer direito fundamental que atribui ao seu titular posições jurídicas a prestações positivas materiais exigirá do Estado a destinação de recursos públicos.

40 Outras relevantes informações sobre o tema podem ser consultadas no texto completo da reportagem. Disponível em: https://noticias.uol.com.br/cotidiano/ultimas-noticias/2019/07/17/superlotadas-prisoes-nobrasil-gastam-r-158-bilhoes-ao-ano-diz-tcu.htm. Acesso em: 24 dez. 2020. 
As normas constitucionais asseguradoras de direitos fundamentais individuais, portanto, também são dependentes de ações positivas estatais, em alguma medida e nem por isso se deixa de reconhecer seu caráter autoexecutável. O que ocorre é que a maior parte das ações positivas exigidas para a proteção já foram historicamente concretizadas em relação aos direitos fundamentais individuais e políticos, em nível relativamente satisfatório. Martins (2020, p. 113) relembra as lições de Catarina Botelho que reforça o entendimento de que a pretensamente "menor e pouco conhecida" onerosidade do que ela denomina "direitos de liberdade" se dá mais por razões históricas e culturais do que por razões jurídicas ou econômicas. Segundo a autora:

[...] a menor relevância atribuída aos custos dos direitos de liberdade poderá explicar-se pelo fato de estes direitos, que historicamente antecedem à geração dos direitos sociais, serem encarados com mais naturalidade, porquanto os cidadãos longamente conviveram com as estruturas administrativas, judiciais e policiais que lhes subjazem, que se foram sedimentando e ganhando consistência (BOTELHO, apud MARTINS, 2020, p. 113).

Jorge Novais assevera que a equiparação entre os direitos de liberdade e direitos sociais carece de um último passo:

[...] o reconhecimento que as limitações aos direitos sociais são restrições a direitos fundamentais pelo que, em Estado de Direito, só são admissíveis quando há razões suficientemente ponderosas que justifiquem a restrição. Mais, que, enquanto direitos fundamentais, os direito sociais não se encontra à livre disposição dos titulares do poder político, pelo que a justificação não se pode sempre bastar com o não ser arbitrária ou falha de qualquer fundamentação racional: ela tem que ser tão mais ponderosa quanto maior gravidade tenha a restrição (por exemplo, os casos de maior fragilidade ou exclusão social ou os casos em que a alteração legislativa em causa cria ou repões uma situação de inconstitucionalidade por omissa). Cabe ao Tribunal Constitucional fazer o controlo da correspondente legitimidade constitucional (NOVAIS, 2006, p. 208)

Não se olvida que, na complexidade da sociedade contemporânea, observa-se uma gama crescente de necessidades e interesses que vão emergindo a partir de novas violações à dignidade humana, promovidos por problemas estruturais de exclusão social, por avanços tecnológicos ou pela assimetria das relações de mercado, acarretando os chamados "custos sociais",41. Assim, a qualquer momento, com a evolução da sociedade, podem-se revelar

41 Em sua análise sobre o tema, Neves (2011, p. 60-61) relembra as lições de Maurizio Franzini o qual, em uma releitura dos custos sociais de K. William Kapp, afirma que tais custos sociais devem ser entendidos como violações de direitos fundamentais sociais básicos perpetrados pelo capitalismo, medidos pelas perdas de 
eventuais lacunas, inclusive na proteção das liberdades individuais, a demandarem novas ações positivas estatais que podem ensejar a alocação de recursos públicos.

A principal diferença, portanto, entre os direitos fundamentais sociais e os direitos fundamentais individuais e políticos é o fato de que esses últimos já estão "sedimentados na sociedade, quanto ao seu conteúdo, alcance em extensão, tendo em vista a longa tradição legiferante e a prática jurídica que a acompanhou" (BAPTISTA; SILVA, 2018, p. 196). Por se encontrarem mais naturalizados e sedimentados é que, aparentemente, para sua proteção, uma ação negativa ou uma "abstenção" do Estado teria mais destaque, com vistas a não reduzir o patamar de efetividade já atingido (BAPTISTA; SILVA, 2018, p. 196) ${ }^{42}$.

Por outro lado, ainda está em curso um processo de consolidação dos direitos fundamentais sociais. Esse processo precisa ser progressivamente aperfeiçoado a fim de que as posições subjetivas definitivas extraídas das normas que veiculam esses direitos sejam cada vez mais delimitadas e protegidas de forma adequada, assim como o têm sido em relação aos direitos fundamentais individuais e políticos. Se a concretização dos direitos fundamentais sociais ainda não ocorreu no mesmo nível dos direitos fundamentais individuais, esse fato se deve mais à insuficiência de decisões políticas conformadoras em nível satisfatório do que

bem-estar na sociedade e que não podem ser quantificadas ou submetidas à ideia de otimização nos moldes de Pareto. "Assim, será totalmente irrelevante se os danos causados pela ação de um agente, medidos pelas perdas de bem-estar por parte de quem os sofre, são maiores ou menores do que as vantagens que daí resultam para quem os produz (uma questão central, como vimos, no quadro da análise convencional das externalidades). Os danos sociais, mesmo que inferiores aos ganhos das empresas, não deixarão de constituir uma violação de direitos sociais e não são, por esse facto, menos importantes. A questão dos custos sociais é, assim, recolocada num plano - o dos direitos sociais [...]" (NEVES, 2011, p. 60-61). Uma consequência que se extrai é que a socialização desses "custos" retira cada vez mais do cidadão e das famílias recursos próprios que poderiam ser utilizados para a satisfação de suas necessidades essenciais, mas cujos ônus lhe são impostos pelo sistema econômico, amparados por decisões políticas no âmbito da economia. A intervenção estatal neste caso é necessária para reequilibrar essas posições assimétricas decorrentes dos impactos negativos do mercado sobre a sociedade.

42 Sobre o nível de proteção historicamente dispensado aos direitos fundamentais individuais e o nível de dependência dessa proteção para que estes fossem considerados direitos exigíveis, Batista e Silva, trazem um exemplo que pode ser mais esclarecedor: Observe-se, ainda, o que dispõe o inciso XXII do artigo $5 .^{\circ}$ da Constituição Federal Brasileira (doravante " $\mathrm{CF} / 88^{\text {"): }}$ "é garantido o direito de propriedade". Aqui, a Constituição não indica como se adquire a propriedade, nem como se deve proceder quando esta está sob ameaça. No entanto, ninguém se lembrará de dizer que este direito fundamental é obscuro demais para ser autoexecutável e exigível perante o poder jurisdicional. Poder-se-ia argumentar, entretanto, que o direito de propriedade passou a ser um direito subjetivo, e por isso mesmo autoexecutável, na medida em que normas infraconstitucionais, nomeadamente as do Código Civil, passaram a protegê-lo adequadamente. No entanto, quando se invoca a aplicabilidade imediata e autoexequibilidade como distintiva dos direitos fundamentais individuais e políticos, assume-se, implicitamente, que eles são independentes da existência de norma regulamentadora. E aqui reside o erro. Da mesma forma, é errôneo pretender que o regime de "aplicação imediata" destes direitos decorra do cumprimento do dever de mera "abstenção" do Estado. [...] As diferenças que efetivamente existirem serão "consequência das opções dos legisladores constituinte e ordinário assim como dos governos", além de decorrerem dos "processos de naturalização e legitimação destas instituições ocultam a forte dimensão positiva dos 'direitos de liberdade' ou ocultam a dependência estrutural destes face àquelas” (BAPTISTA e SILVA, 2018, p. 197-198). 
pela natureza diferenciada desses direitos ou pela efetiva escassez de recursos ${ }^{43}$.

Portanto, na medida em que se reconhece que todos os direitos fundamentais, sejam individuais, políticos ou sociais, demandam em certa medida a destinação de recursos para sua efetivação na sociedade ou, ao menos, para a garantia do padrão de proteção já alcançado, constata-se que todos os direitos fundamentais vão demandar, no mínimo, uma interposição normativa do legislador orçamentário para garantir que a norma constitucional alcance seus plenos efeitos, sem distinção. E, quando da constatação de que os recursos não são suficientes para o atendimento de todas as prestações necessárias à efetivação dos direitos fundamentais em geral, o princípio da reserva do possível delimitará as possibilidades jurídicas para se aferir razoabilidade da pretensão individual frente às limitações decorrentes de alocações orçamentárias também razoáveis.

\subsection{RESTRIÇÕES A DIREITOS FUNDAMENTAIS: BREVES CONSIDERAÇÕES SOBRE} A TEORIA INTERNA (INNENTHEORIE) E A TEORIA EXTERNA (AUSSENTHEORIE) E O PRINCÍPIO DA RESERVA DO POSSÍVEL

Como explanado no primeiro capítulo desta dissertação, uma das principais controvérsias sobre a natureza jurídica do princípio da reserva do possível tem, como pressuposto subjacente, a divergência doutrinária sobre a natureza das restrições e limites a que os direitos fundamentais podem estar sujeitos. A consideração da regra constitucional que atribui aplicabilidade imediata prevista às normas constitucionais veiculadoras de direitos fundamentais - sejam de direitos fundamentais individuais ou sociais - não pode ser confundida com a negativa de limitações fáticas e jurídicas, ou de restrições, que possam atingir o conteúdo desses direitos. Inexiste direito fundamental imune a qualquer tipo de restrição ou limite (SARLET, 2017a, p. 601).

Jane Reis Gonçalves Pereira (apud MOREIRA, 2011), ao tratar das restrições a direitos fundamentais, argumenta que essas restrições decorreriam da própria necessidade de solucionar conflitos de direitos que pretendem ser universais e foram constitucionalizados em conjunto. Em suas palavras:

Em primeiro lugar, a universalidade dos direitos torna imperativa sua limitação. Sendo os direitos fundamentais atribuídos a todas as pessoas, não há como conceber

\footnotetext{
${ }^{43}$ Para Olsen (2006, p. 191-192), "a escassez dos recursos econômicos destinados à realização destes direitos não é natural, essencial, mas artificial, fruto da escolha realizada pelos poderes públicos".
} 
sua fruição permanente e simultânea sem que haja uma disciplina ordenadora a viabilizar que estes coexistam. Só é possível tornar efetiva a titularidade universal dos direitos à medida que sejam harmonizados, o que implica logicamente a imposição de limites. Em segundo lugar, os direitos fundamentais são constitucionalizados como um conjunto, não isoladamente. Nessa perspectiva, o reconhecimento dos direitos traz ínsita a noção de que estes estão inseridos num ordenamento complexo e plural, de modo que a determinação de sua esfera de incidência impõe que sejam coordenados com outros direitos e bens protegidos pela Constituição. Esses dois aspectos conjugados ligam-se à forte propensão dos direitos fundamentais a chocar-se. A necessidade de solucionar conflitos de direitos implica, naturalmente, o estabelecimento de restrições em sua aplicação (PEREIRA, apud MOREIRA, 2011, p. 70-71).

Duas principais teorias disputam posições acerca da restrição a direitos fundamentais. A primeira, denominada teoria interna (Innentheorie) ${ }^{44}$, sustenta que os direitos fundamentais estão sujeitos a limites imanentes, os quais estariam inseridos no âmbito da própria norma de direito fundamental e que definem a priori a extensão do conteúdo desse direito, excluindo-se de antemão determinadas condutas do âmbito de proteção da norma (MARTINS, 2020, p. 138). Alexy $(2015$, p. 278) adverte que, no caso da teoria interna, o direito e sua restrição se fundem em um único elemento a ser analisado: o direito com um determinado conteúdo. $\mathrm{O}$ conceito de restrição é substituído pelo conceito de limite ou de restrições imanentes. Esses limites decorreriam da própria natureza do direito, afastando, de plano, todo conteúdo que o direito não visava a proteger, a partir da análise que for constitucionalmente estabelecida. Neste caso não há que se falar em colisões de direitos, pois cada direito já teria seu âmbito e limites pré-definidos ${ }^{45}$.

Parte da doutrina que aborda o problema da exigibilidade dos direitos fundamentais a partir dos pressupostos da teoria interna afirma que a reserva do possível caracterizaria um limite aos direitos fundamentais sociais, determinando sua existência e exigibilidade. Neste aspecto, a reserva do possível é tratada não como um princípio jurídico, mas como uma limitação fática determinada exclusivamente pela inexistência ou insuficiência de recursos disponíveis para o atendimento a um direito fundamental ${ }^{46}$. Esse posicionamento sofre

\footnotetext{
${ }^{44}$ A teoria interna se coaduna com a ideia do suporte fático restrito a qual exclui a priori determinadas condutas do âmbito de proteção das normas, não deixando espaço para o reconhecimento de restrições ou colisões entre direitos (MOREIRA, 2011, p. 64-65).

${ }^{45}$ Jane Reis Gonçalves Pereira elabora uma síntese dos principais pontos da teoria interma. Segundo a autora essa teoria: "i) nega a possibilidade de limitações externas aos direitos, ii) afirma que a identificação dos casos em que o direito deve incidir há de ser feita mediante análise de seu conteúdo constitucionalmente estabelecido e iii) recusa a hipótese de colisões de direitos" (PEREIRA apud MOREIRA, 2011, p. 73).

${ }^{46}$ Martins (2020, p. 140) ressalta que esse é o entendimento de Flávio Galdino: "na medida em que o Estado é indispensável ao reconhecimento e efetivação dos direitos, e considerando que o Estado somente funciona em razão das contingências de recursos econômico-financeiros captados junto aos indivíduos singularmente considerados, chega-se à conclusão de que os direitos só existem onde há fluxo orçamentário que o permita" .
} 
inúmeras críticas, principalmente quando se trata de caracterizar o princípio da reserva do possível como um limite imanente dos direitos fundamentais. Nesse sentido, Olsen observa:

Ver na reserva do possível um limite imanente dos direitos fundamentais, ainda que seja logicamente aceitável, gera um grave enfraquecimento no sistema de proteção destes direitos, já que poderes constituídos legitimados a descrever o âmbito normativo de um direito, com seus limites inerentes, terão total discricionariedade para afirmar o que é possível e o que não é. [...] A escassez dos recursos econômicos destinados à realização destes direitos não é natural, essencial, mas artificial, fruto da escolha realizada pelos poderes públicos (OLSEN, 2006, p. 191-192).

No mesmo sentido está o posicionamento de Virgílio Afonso da Silva. Ao tratar da teoria interna, o autor afirma que:

[...] de acordo com a teoria interna, 'existe apenas um objeto, o direito com seus limites imanentes'. A fixação desses limites, por ser um processo interno, não é definida nem influenciada por aspectos externos, sobretudo não por colisões com outros direitos. Se isto é assim - ou seja, se a definição do conteúdo e da extensão de cada direito não depende de fatores externos e, sobretudo, não sofre influência de possíveis colisões posteriores -, a conclusão a que se pode chegar, em termos de estrutura normativa, é que direitos definidos a partir do enfoque da teoria interna têm sempre a estrutura de regras. Isso porque, se a definição do conteúdo do direito é feita de antemão, isso significa, para usar a expressão de Sieckmann, que a norma que o garante tem validade estrita. Segundo ele, validade estrita significa que uma norma será com certeza aplicável e produzirá todos os seus efeitos sempre que se tratar de uma situação que se enquadre na hipótese por ela descrita Se a norma tem validade estrita, ela segue o raciocínio "tudo-ou-nada", analisado anteriormente, e não pode ser objeto de sopesamentos (SILVA, 2006, p. 37).

Por sua vez, para os adeptos da teoria externa (Aussentheorie) ${ }^{47}$, restrições e direitos não se confundem. Alexy (2015, p. 281) esclarece que "restrições a direitos fundamentais são normas que restringem uma posição prima facie de direito fundamental”. Alexy (2015, p. 281) esclarece que "restringíveis são os bens protegidos por direitos fundamentais (liberdades/situações/posições de um direito ordinário) e as posições prima facie garantidas

\footnotetext{
${ }^{47}$ A teoria externa tem como pressuposto o suporte fático amplo em relação aos direitos fundamentais. A lição de Robert Alexy é que a adoção da teoria ampla do suporte fático inclui no âmbito de proteção de cada princípio de direito fundamental todos os pressupostos materiais que milite em favor da proteção do bem jurídico que o direito resguarda, definindo, pois, o que é resguardado prima facie (consequência jurídica prima facie). $\mathrm{O}$ suporte fático é, portanto, um conceito contraposto ao conceito de restrição (ALEXY, 2015, p. 305). Assim, Alexy esclarece que a teoria ampla do suporte fático trabalha em dois âmbitos: de casos potenciais e de casos reais. "Sempre que um princípio de direito fundamental for relevante, o caso é pelo menos um caso potencial de direitos fundamentais, não importa com que grau de certeza o princípio em questão possa ser superado por princípios colidentes" (ob. cit., p. 328).
} 
por princípios de direitos fundamentais". Portanto, as restrições às normas de direitos fundamentais vão incidir sobre os bens protegidos em suas posições prima facie, ou seja, naquilo que, no princípio, corresponde a algo considerado em abstrato e que apresenta, então, conteúdo excedente.

Assevera-se, ainda, que uma restrição a um direito fundamental, para que seja constitucionalmente aceita, deve decorrer de outra norma válida, extraída do ordenamento jurídico. As normas restritivas podem se apresentar na forma de regras ou de princípios. Uma regra constitui uma restrição a um direito fundamental quando cria uma não-liberdade definitiva ou um não direito definitivo no lugar da liberdade ou do direito fundamental prima facie $^{48}$.

Princípios colidentes têm aptidão de restringir materialmente as possibilidades jurídicas de realização de outros princípios (ALEXY, 2015, p. 282-283). Contudo, Alexy adverte que, tecnicamente, não são os princípios que assumem o papel de restrições a outras normas, "mas somente as regras que, de acordo com a lei de colisão, expressam o resultado do sopesamento" (ALEXY, 2015, p. 284). Isso porque os princípios não têm aptidão para colocar o indivíduo diretamente em uma posição definitivamente restringida. Para haver essa restrição definitiva é necessária a ponderação entre o princípio constitucional atingido e os princípios que o restringem. Por sua vez, a restrição vai ocorrer somente se esse princípio for uma razão para que, no lugar do direito ou liberdade fundamental prima facie, prevaleça uma não-liberdade definitiva ou um não-direito definitivo (ALEXY, 2015, p. 282-285).

A ponderação é uma técnica adequada para se extrair o máximo de eficácia possível dos direitos fundamentais veiculados mediante normas principiológicas que se encontram em situação de colisão no caso concreto. Essa solução tem como premissa admitir-se a possibilidade de restrição do conteúdo prima facie de um determinado princípio a partir de razões que justifiquem a prevalência da proteção exigida por outros princípios colidentes, que lhe condiciona as possibilidades jurídicas. Alexy (2015, p. 514) esclarece que aquilo que é devido prima facie é mais amplo que aquilo que é devido definitivamente. Isso porque, no direito objetivamente assegurado há sempre algo de excedente e que pode ser restringido por

\footnotetext{
${ }^{48}$ Alexy (2015, p. 286-288) faz uma distinção entre restrição e cláusula restritiva. "O conceito de restrição pertence à perspectiva do direito, enquanto que o conceito de cláusula restritiva pertence à perspectiva da norma. Uma cláusula restritiva é parte de uma norma de direito fundamental completa, que diz como aquilo que, prima facie, é garantido pelo suporte fático do direito fundamental foi ou pode ser restringido. Cláusulas restritivas podem ser escritas ou não escritas. Serão consideradas, em primeiro lugar, as cláusulas restritivas escritas que contêm restrições diretamente constitucionais". Para o autor, quando extraídas da Constituição, a "cláusula nada mais é que uma decisão do constituinte a favor de determinadas razões contra a proteção constitucional".
} 
princípios colidentes. Nesse raciocínio, o direito definitivo à prestação é identificado "quando o princípio da liberdade fática tem um peso maior que os princípios formais e materiais colidentes, considerados em conjunto" (ALEXY, 2015, p. 512-517). Ou seja, a restrição ao princípio que veicula um direito fundamental é algo externo ao seu conteúdo protegido, que mais se aproxima da ideia de restrição a direitos fundamentais, afastando a noção de limites imanentes ${ }^{49}$.

Para os adeptos da teoria externa das restrições aos direitos fundamentais, o princípio da reserva do possível tem a natureza de uma restrição externa às posições prima facie das normas principiológicas que veiculam dos direitos fundamentais, o que se coaduna com o modelo da teoria dos princípios alexyana. Nesse modelo, em um caso concreto, o conteúdo definitivo do bem protegido por um direito fundamental - seja o direito fundamental individual ou social - pode ser extraído por meio de um juízo de ponderação, quando colidir com o princípio da reserva do possível, o qual demanda a razoabilidade da prestação requerida pelo particular em face da escassez de recursos públicos alocados de forma igualmente razoável.

Do resultado dessa ponderação entre o princípio da reserva do possível e o princípio de direito fundamental colidente poderá ser extraída uma regra que constituirá razão para fundamentar uma restrição ao conteúdo prima facie desse direito fundamental (ALEXY, 2015, p. 284) e que poderá ser aplicada em outros casos, desde que presentes circunstâncias fáticas, jurídicas e epistêmicas semelhantes. Nestes casos, o princípio da reserva do possível constituirá uma razão para o indeferimento da prestação requerida pelo particular.

A questão que se coloca é: existem condições para que a efetivação de uma prestação material, protegida por uma norma de direito fundamental, seja negada pela aplicação do princípio da reserva do possível? Ou, ainda, toda e qualquer pretensão do particular a prestações materiais estatais estará sujeita à ponderação com o princípio da reserva do possível? Para responder a essa questão, a doutrina recorre à teoria das "restrições às restrições" (Schranken der Schranken) aos direitos fundamentais, abaixo apreciada.

\footnotetext{
${ }^{49}$ Sgarbossa (2010, p. 226) defende uma posição intermediária que tentaria conciliar a teoria externa e a teoria interna. Para sustentar essa posição, o autor parte da identificação da reserva do possível fática (baseada na escassez real) como um limite imanente e a reserva do possível jurídica (opção alocativa do legislador) como uma restrição. Essa posição também é seguida por outros autores como Martins (2020, p. 140).
} 


\subsection{LIMITES À APLICAÇÃO DO PRINCÍPIO DA RESERVA DO POSSÍVEL: TEORIA DAS “RESTRIÇÕES ÀS RESTRIÇÕES”}

Determinado que o princípio da reserva do possível possui aptidão para fundamentar restrições ao conteúdo prima facie de normas de direitos fundamentais, passa-se a levantar a questão da existência de limites a estas restrições. Como asseverado por Alexy (2015, p. 515), ao examinar a decisão numerus clausus I, do Tribunal Constitucional Federal alemão, a cláusula restritiva do direito prima facie vinculante - a reserva do possível - "não pode levar a um esvaziamento do direito".

Nessa esteira, a doutrina alemã também começou a discutir a ideia de "restrição às restrições" aos direitos fundamentais. A denominada teoria das "restrições às restrições" (Schranken der Schranken) também possui berço alemão e tem sua elaboração atribuída à Karl August Betterman, o qual, em conferência realizada em 1964, reconheceu que "as limitações aos direitos fundamentais são legítimas quando atendem a um conjunto de condições materiais e formais, "que são os limites dos limites dos direitos fundamentais"” (MOREIRA, 2011, p. 104).

Nessa linha, Canotilho (2003, p. 451) afirma que leis restritivas de direitos estão sujeitas a uma série de requisitos que podem ser de natureza formal ou material. Estes requisitos podem estar contidos em regras ou em princípios da constituição. Para o autor, os requisitos de natureza formal (exigência de lei, ou expressa autorização restritiva contida na constituição) atuam como uma "zona de proteção formal" na medida em que cumprem requisitos procedimentais. Por sua vez, os requisitos materiais pretendem assegurar "a conformidade substancial da lei restritiva como os princípios e regras da Constituição [...]" (CANOTILHO, 2003, p. 452).

Sarlet (2013, p. 31-32), ao tratar da necessidade de responsabilidade e cautela por parte dos órgãos do Poder Judiciário na efetivação dos direitos fundamentais sociais, afirma que

[...] dada a íntima conexão dessa problemática com a discussão em torno da assim designada 'reserva do possível' na condição de limite fático e jurídico à efetivação judicial (e até mesmo política) de direitos fundamentais [...] vale destacar que também resta abrangida a obrigação de todos os órgãos estatais de maximizar os recursos e minimizar o impacto da reserva do possível (SARLET, 2013, p. 32).

Como visto no primeiro capítulo, Sarlet atribui ao princípio da reserva do possível 
(além da exigência da proporcionalidade da prestação e de sua razoabilidade), uma dimensão jurídica e uma dimensão fática. Sarlet (2013, p. 32-34) elenca, além da proteção ao mínimo existencial, o que denominou de "outras possibilidades disponíveis da nossa ordem jurídica" para minimizar o impacto da reserva do possível no caso de prestações que transcendem ao mínimo existencial. Dentre elas, o autor destaca o princípio da proporcionalidade (em suas dimensões de proibição do excesso e de insuficiência), atuando no controle dos atos do Poder Público, o controle judicial das opções orçamentárias e da legislação relativa aos gastos públicos em geral; do controle das decisões políticas acerca da alocação de recursos, no tocante à transparência das decisões e a viabilização do controle social sobre a aplicação dos recursos alocados. O autor chama a atenção para a consideração dos princípios da moralidade e eficiência na atuação da administração pública e na administração da escassez de recursos e na otimização dos direitos sociais (SARLET, 2013, p. 32).

Partindo da abordagem de Sarlet quanto às dimensões que o princípio da reserva do possível pode assumir, Sgarbossa (2010, p. 273-339) relaciona diferentes tipos de restrições à reserva do possível, a depender da dimensão que se apresentar no caso concreto ${ }^{50}$. Para este autor, o princípio da reserva do possível pode atuar como restrição jurídica a direitos fundamentais, relacionando-se às escolhas alocativas orçamentárias do legislador. Neste caso, levanta-se como restrição à prevalência desse princípio a observância da proibição de excesso, da proibição de proteção deficiente, da proteção do núcleo essencial, do princípio da proibição do retrocesso e da proteção ao mínimo existencial. Por outro lado, quando o princípio da reserva do possível figurar como uma limitação fática, ou seja, a inexistência efetiva de recursos, o autor traz como limites à sua aplicação: o princípio da progressividade, princípio da aplicação máxima dos recursos disponíveis, princípio da interdependência e da indivisibilidade dos direitos humanos (SGARBOSSA, 2010, p. 273-339).

Por sua vez, Martins (2020, p. 156-163) traz os seguintes limites ou critérios para se aferir a constitucionalidade das restrições impostas pelo princípio da reserva do possível à efetivação do conteúdo das normas de direitos fundamentais, em relação à sua dimensão jurídica: o princípio da proporcionalidade, o princípio da razoabilidade, o mínimo existencial e o princípio da proibição do retrocesso.

Conquanto, nesta pesquisa, tenha sido elaborado um conceito próprio da reserva do possível, que recebeu o tratamento de princípio, compatível com a teoria alexyana que trata da máxima da proporcionalidade, serão abordadas somente as restrições ao princípio da reserva

\footnotetext{
${ }^{50}$ Relembrando que o autor não trata a reserva do possível como princípio jurídico.
} 
do possível que se apresentem pertinentes a esse conceito.

Antes de discorrer sobre as restrições a serem tratadas nesta pesquisa que incidem sobre a aplicação do princípio da reserva do possível, algumas observações devem ser feitas quanto à razoabilidade e à proporcionalidade. Alguns autores afirmam tanto a proporcionalidade quanto a razoabilidade como restrições à reserva do possível. É certo que ambas atuam como restrições às intervenções em direitos fundamentais em geral. Contudo, a partir da proposta deste trabalho, não se entende correto atribuir-lhes o caráter de restrições à reserva do possível. Primeiro, porque a razoabilidade é integrante do próprio objeto do principio da reserva do possível, como proposto. Não seria lógico afirmar que a razoabilidade é uma restrição externa “àquilo que o indivíduo pode razoavelmente esperar da sociedade", porque o âmbito do razoável já está inserido no objeto de otimização do princípio da reserva do possível. Quanto à proporcionalidade, não seria coerente afirmar que ela é uma restrição ao princípio da reserva do possível, porque, na colisão principiológica, a restrição sofrida por um princípio será gerada pela necessidade de realização do princípio colidente, cujo ponto ótimo é definido pela utilização da máxima da proporcionalidade. A depender das razões extraídas do caso concreto, tanto o princípio da reserva do possível, quanto o princípio de direito fundamental colidente podem prevalecer.

A proporcionalidade é uma técnica adequada para se extrair a máxima eficácia possível dos direitos fundamentais veiculados através de normas principiológicas que se encontram em situação de colisão no caso concreto. Dessa forma, ao contrário de consistir em uma restrição ao princípio da reserva do possível ou a qualquer outro princípio, a proporcionalidade é um método prescritivo de solução de colisão principiológica que possibilita atribuir aos princípios a máxima efetividade possível no contexto de sua colisão.

Afasta-se, pois, a análise da proporcionalidade e da razoabilidade como restrições ao princípio da reserva do possível. Contudo, o posicionamento que a doutrina analisada vem defendendo têm sua coerência dentro de outras abordagens da reserva do possível e que identificam a reserva do possível com a escassez ou limitação dos recursos públicos, seja ela na dimensão fática ou jurídica.

A seguir, serão abordadas as restrições consideradas mais pertinentes tendo em mira o conceito de reserva do possível e sua natureza principiológica. São elas: a) o mínimo existencial; b) a proteção do núcleo essencial e demais posições definitivas reconhecidas por precedentes judiciais ou por decisões com efeitos vinculantes; c) o princípio da máxima aplicação dos recursos disponíveis. 


\subsubsection{O mínimo existencial}

A inoponibilidade da reserva do possível ao direito ao mínimo existencial é amplamente tratada tanto na doutrina quanto na jurisprudência brasileira. Cumpre salientar, no entanto, que não existe consenso sobre o conteúdo concreto de direitos que integram o denominado direito ao mínimo existencial. O que se observa é uma convergência no tocante à fundamentação jurídico-constitucional do tema, a partir do direito à vida e do princípio da dignidade da pessoa humana (SARLET; FIGUEIREDO, 2013, p. 23). Assim, o mínimo existencial vem sendo associado a um complexo básico de direitos reconhecidos como garantia das condições materiais mínimas para uma vida digna.

O tema foi inicialmente abordado na Alemanha por Otto Bachof, em 1954, em obra na qual afirmou que o princípio da dignidade da pessoa humana, inserido na Constituição alemã, “não reclama apenas a garantia da liberdade, mas também um mínimo de segurança social, já que, sem os recursos materiais para uma existência digna, a própria dignidade da pessoa humana ficaria sacrificada" (SARLET, FIGUEIREDO, 2013, p. 20). Bachof reconheceu, ainda, uma obrigação estatal de garantir "um mínimo de existência assegurado" (Existenzminimum). O autor defende como conteúdo do mínimo existencial o direito à alimentação, vestuário e moradia (TOLEDO, 2019, p. 222). A partir de então, o próprio Tribunal Constitucional Federal alemão, em vários julgados, começou a reconhecer o direito fundamental a uma existência digna ${ }^{51}$ (MARTINS, 2020, p. 165).

Alexy, em sua obra Teoria dos Direitos Fundamentais, afirma a exigibilidade dos direitos que compõem o mínimo existencial, porquanto se caracterizam como direitos subjetivos e definitivos à prestação, esclarecendo que

51 A exemplo da decisão do Tribunal Constitucional Alemão é a BVerfGE 125, 175, de 9 de fevereiro de 2010, "cujo objetivo foi a aplicação da reforma legislativa conhecida como Hartz IV388. Nessa decisão, entendeuse que o mínimo existencial implica na garantia da manutenção da existência física do indivíduo (mínimo vital), como alimentação, vestuário, moradia, aquecimento, higiene, saúde, como também implica na participação mínima na vida social, cultural e política, consistindo em direito subjetivo. Consta da ementa da decisão: 'o direito fundamental a uma subsistência decente decorre do art. $1^{\circ}$, par. $1^{\circ}$ da Lei Fundamental, em conjunto com o princípio do Estado Social (do artigo 20) garante a cada carente requisitos substantivos para sua existência física e para um nível mínimo de participação na vida social, cultural e política". Outrossim, a forma através da qual será cumprido esse mínimo existencial está dentro de um 'espaço de ação', "margem de manobra", 'espaço de conformação' ou "margem de discricionariedade" (Gestaltungsspielraum) por parte do legislador: o cumprimento do mínimo existencial "requer a concretização e atualização contínua por parte do legislador, que deve alinhar os serviços a serem prestados com o respectivo nível de desenvolvimento da comunidade e as condições de vida existentes'. Quanto maior a vinculação com o mínimo vital, menor o grau de discricionariedade do legislador (MARTINS, 2020, p. 171). 
De acordo com o modelo proposto, o indivíduo tem um direito definitivo à prestação quando o princípio da liberdade fática tem um peso maior que os princípios formais e materiais colidentes, considerados em conjunto. Esse é o caso dos direitos mínimos. É possivelmente a esse tipo de direitos mínimos que se quer fazer referência quando direitos subjetivos públicos e judicialmente exigíveis a prestações são contrapostos ao conteúdo objetivo excedente (ALEXY, 2015, p. 512-517).

Por sua vez, quando Alexy se refere ao conteúdo dos direitos fundamentais sociais mínimos, inclui o direito a um mínimo vital, a uma moradia simples, à educação escolar, à formação profissional e a um nível padrão mínimo de assistência médica (ALEXY, 2015, p. 512).

No Brasil, uma das primeiras referências da doutrina ao mínimo existencial foi feita por Ricardo Lobo Torres (1989, p. 1-4) ${ }^{52}$. Para o autor, o mínimo existencial não tem dicção constitucional própria e assim carece de conteúdo específico. Por tal razão, abrangeria “qualquer direito, ainda que originariamente não-fundamental (direito à saúde, à alimentação etc.), considerado em sua dimensão essencial e inalienável”. Por sua vez, seu conteúdo não se esgotaria em nenhum catálogo de direitos preexistente, sendo dotado de historicidade, variando de acordo com o contexto social. Prossegue afirmando que o mínimo existencial exibe as características básicas dos direitos da liberdade: é pré-constitucional, posto que inerente à pessoa humana e por isso constitui direito público subjetivo do cidadão, não sendo outorgado pela ordem jurídica, mas condicionando-a. Dessa forma, tais direitos seriam plenamente exigíveis, independentemente de atuação legislativa (TORRES, 1989, p. 4).

Daniel Sarmento (2016, p. 1659) afirma que “como dimensão do princípio da dignidade da pessoa humana, o direito ao mínimo existencial possui caráter universal, sendo titularizado por todas as pessoas naturais, independentemente de qualquer outra condição".

Barcellos (2002, p. 293-301) afirma que o mínimo existencial trata-se de um direito fundamental que, embora derivado diretamente do princípio da dignidade da pessoa humana, também se relaciona a boa parte dos direitos fundamentais sociais positivados pela Constituição de 1988, como saúde, educação, moradia, alimentação, previdência e assistência social e em alguns direitos fundamentais individuais, como o acesso à justiça.

Por sua vez, de forma acertada, Cláudia Toledo (2019, p. 217) adverte para o fato de que "da destinação arbitrária de direitos ao mínimo existencial resulta exatamente situação oposta àquela visada por sua criação, uma vez que o mínimo é transformado em 'máximo'

52 O artigo pioneiro sobre o tema foi publicado na Revista de Direito Administrativo, no 177, em 1989, entitulado "O mínimo existencial e os direitos fundamentais". Disponível em: http://bibliotecadigital.fgv.br/ojs/index.php/rda/article/view/46113/44271. Acesso em: 22 abr. 2020. 
existencial ou vital, fator que lhe diminui a força vinculante" ${ }^{, 53}$. E por tal razão destaca "a necessidade premente de delimitação conceitual precisa do que pode ser entendido como mínimo existencial” (TOLEDO, 2019, p. 217). Após uma análise do tratamento do mínimo existencial em outros países, assevera que esse direito vai além da garantia de que o indivíduo "seja simplesmente um ser vivo", mas seja "um ser humano, inserido em um meio sociocultural". E a autora conclui que

saúde e educação são então os direitos fundamentais sociais entendidos como mínimos para garantia de patamar elementar de dignidade humana, no contexto brasileiro atual. O núcleo essencial de cada um desses direitos é definido com base nas condições fáticas brasileiras, ou seja, na realidade socioeconômica nacional (TOLEDO, 2019, p. 223).

Embora a Constituição de 1988 não estabeleça de forma expressa a proteção a "um mínimo existencial" ${ }^{54}$, Toledo (2019, p. 217), inspirada nas lições de Alexy afirma que "o direito ao mínimo existencial é o único direito definitivo entre os direitos fundamentais, estipulado por norma constitucional com estrutura de regra”. Corroborando essa afirmação, o próprio Supremo Tribunal Federal já se manifestou no Agravo Regimental no Recurso Extraordinário $n^{\circ}$ 639.337-SP, que o mínimo existencial é extraído de forma implícita dos preceitos constitucionais inseridos no artigo $1^{\circ}$, inciso III, e artigo $3^{\circ}$, inciso III, da Constituição Federal (BRASIL, STF, 2011) ${ }^{55}$.

53 Toledo destaca que "a fixação do conteúdo do mínimo existencial pela doutrina nacional varia desde diferentes direitos fundamentais sociais como saúde, educação, assistência social; passando por direitos fundamentais individuais (direitos de liberdade); chegando a institutos outros que nem mesmo direitos fundamentais são, como a "proteção negativa contra a incidência de tributos sobre os direitos fundamentais sociais mínimos de todas as pessoas"” (TOLEDO, 2019, p. 222).

54 A norma que mais se aproxima da proteção ao mínimo existencial está inserida no artigo 79 do Ato das Disposições Constitucionais Transitórias (ADCT) que assegura: “Art. 79. É instituído, para vigorar até o ano de 2010, no âmbito do Poder Executivo Federal, o Fundo de Combate e Erradicação da Pobreza, a ser regulado por lei complementar com o objetivo de viabilizar a todos os brasileiros acesso a níveis dignos de subsistência, cujos recursos serão aplicados em ações suplementares de nutrição, habitação, educação, saúde, reforço de renda familiar e outros programas de relevante interesse social voltados para melhoria da qualidade de vida" (BRASIL, ADCT, 2000). Pode-se deduzir desse dispositivo que a proteção a um mínimo digno de subsistência englobaria prestações relacionadas à alimentação, habitação, educação saúde e assistência familiar.

55 “Além do fundamento constitucional, o mínimo existencial está previsto no artigo 11, 1, do Pacto Internacional sobre Direitos Econômicos, Sociais e Culturais, que ingressou no ordenamento jurídico brasileiro por meio do Decreto Presidencial n. 591, de 6 de julho de 1992. Segundo o sobredito dispositivo, 'Os Estados-Partes do presente Pacto reconhecem o direito de toda pessoa a um nível de vida adequado para si próprio e para sua família, inclusive à alimentação, vestimenta e moradia adequadas, assim como a uma melhoria contínua de suas condições de vida. Os Estados-Partes tomarão medidas apropriadas para assegurar a consecução desse direito, reconhecendo, nesse sentido, a importância essencial da cooperação internacional fundada no livre consentimento"” (MARTINS, 2020, p. 244). 
Da pesquisa empírica realizada neste trabalho, verifica-se que, nas vezes em que o princípio da reserva do possível foi afastado por inoponibilidade ao mínimo existencial, houve uma multiplicidade de conteúdos inseridos neste último conceito. Verificou-se terem sido abordados como mínimo existencial uma variedade de conteúdos relacionados ao direito à saúde, à educação, à dignidade dos presos a não sofrerem tratamento desumano e degradante, entre outros ${ }^{56}$.

Sarlet (2017, p. 603) também reconhece que há uma tendência doutrinária e jurisprudencial (com destaque aqui para a jurisprudência do STF) no sentido da possibilidade de reconhecimento de um direito subjetivo definitivo (portanto, gerador de uma obrigação de prestação por parte do destinatário), pelo menos no plano do mínimo existencial, “concebido como garantia (fundamental) das condições materiais mínimas para uma vida com dignidade". Constata, ainda, que o tema tem maior incidência, especialmente nos casos do direito à saúde e à educação, em consonância com a proposta de Cláudia Toledo.

Importante destacar a importância da não redução do conteúdo atribuído ao mínimo existencial somente que a doutrina denomina de "mínimo vital", uma vez que este somente assegura a mera existência biológica, sendo que aquele abrange também os elementos necessários a uma existência humana digna. Sobre essa diferenciação, Martins esclarece que

\begin{abstract}
Dessa maneira, não se pode confundir o mínimo existencial com o mínimo vital ou mínimo de sobrevivência, pois esse é um corolário do direito à vida (art. $5^{\circ}$, caput, da Constituição Federal). Não permitir que alguém morra de fome, embora seja o primeiro e mais básico aspecto do mínimo existencial, com ele não se confunde. O mínimo existencial é um conjunto de garantias materiais para uma vida condigna, que implica deveres de abstenção e ação por parte do Estado. Confundir o mínimo existencial com o mínimo vital (de sobrevivência física) é reduzir o mínimo existencial ao direito à vida. Ora, o direito ao mínimo existencial é muito mais que isso: "implica uma dimensão sociocultural, que também constitui elemento nuclear a ser respeitado e promovido, razão pela qual determinadas prestações em termos de direitos culturais haverão de estar sempre incluídas no mínimo existencial (MARTINS, 2020, p. 192).
\end{abstract}

Como anteriormente analisado, as restrições aos direitos fundamentais não vão incidir

56 Como exemplo colaciona-se trecho da ementa do ARE no 693.337-SP, anteriormente citado: "A noção de 'mínimo existencial', que resulta, por implicitude, de determinados preceitos constitucionais (CF, art. 1', III, e art. $3^{\circ}$, III), compreende um complexo de prerrogativas cuja concretização revela-se capaz de garantir condições adequadas de existência digna, em ordem a assegurar, à pessoa, acesso efetivo ao direito geral de liberdade e, também, a prestações positivas originárias do Estado, viabilizadoras da plena fruição de direitos fundamentais sociais básicos, tais como o direito à educação, o direito à proteção integral da criança e do adolescente, o direito à saúde, o direito à assistência social, o direito à moradia, o direito à alimentação e o direito à segurança" (BRASIL, STF, 2011). 
sobre posições jurídicas definitivas, mas sobre as posições jurídicas prima facie, ou seja, naquilo que, no princípio, corresponde ao conteúdo excedente e que pode ser restringido e extraído do "acervo de normas constitucionais" (ALEXY, 2015, p. 280). Essa característica afasta a oponibilidade ou conflito do princípio da reserva do possível com o direito ao mínimo existencial, eis que este já se trata de uma posição definitiva de direito fundamental.

Sobre a relação do mínimo existencial com o princípio da reserva do possível, destaca-se a posição de Moura e Ribeiro (2017, p. 230). E conceituam o mínimo existencial da seguinte forma:

[...] o mínimo existencial consistiria em "núcleo irredutível e indisponível, insuscetível de ponderação e restrições pelo legislador - impondo a sua realização na dimensão máxima através da promoção de prestações negativas e positivas, insuscetíveis de restrições pelos poderes públicos e plenamente garantidos pela jurisdição. [...] é possível extrair dentro de um universo de prestações capazes de promover os bens e interesses de cada direito social, aquelas conexas a preservação da liberdade, que serão exigíveis independente de reserva orçamentária ou intermediação do legislador e outras ligadas à justiça social dependentes de uma otimização progressiva e dos recursos disponíveis (MOURA, RIBEIRO, 2017, p. 229-230).

Moura e Ribeiro (2017, p. 229) afirmam que coexistem duas espécies de dever para o Estado na implementação dos direitos sociais. De um lado, haveria um "dever de maximização pelo Estado do conteúdo dos direitos sociais que integra o mínimo existencial" - neste caso não sujeito à ponderação. De outro, os autores defendem um "dever de otimização" relativo ao fornecimento de prestações materiais "que excede a este conjunto básico realizável". Neste último caso, tais prestações seriam "exigíveis originariamente por via do exercício da cidadania reivindicatória, e de forma subsidiária pelo Poder Judiciário, observadas as reservas de distintas ordens a que estão sujeitos" (MOURA, RIBEIRO, 2017, p. 229).

Como visto no primeiro capítulo, em uma linha diversa, Ricardo Lobo Torres distingue a reserva do possível daquilo que denomina reserva de orçamento e, assim, aqueles direitos que recaíssem na esfera do mínimo existencial seriam excepcionados da ponderação relativa à reserva do possível, mas não em relação à reserva de orçamento. Cumpre esclarecer que, sob a ótica da teoria dos princípios de Alexy, não há coerência lógica nesse afastamento da ponderação entre o direito ao mínimo existencial e o princípio da reserva do possível, de um lado, e a determinação de sua ponderação com outro princípio - o da reserva orçamentária -, uma vez que não se ponderam direitos subjetivos definitivos. Assim, muito embora para a 
efetivação do mínimo existencial também incida a utilização de recursos públicos, por se tratar de uma regra jurídica, a ponderação com o princípio da reserva do possível é afastada. Isso porque o conteúdo do mínimo existencial dispensa a análise da razoabilidade da pretensão, visto que esse requisito é preenchido de plano, por sua íntima relação com a dignidade humana e com a liberdade fática (como defende Robert Alexy). Outra consequência é que, em relação à questão orçamentária, afastar a ponderação em relação a prestações do mínimo existencial implica reconhecer juridicamente um dever de priorização desse gasto a ser observado pelo legislador orçamentário e pelo administrador público. A alegação de não haver recursos suficientes ao atendimento das prestações relativas ao mínimo existencial vai exigir razões extremamente fortes para justificar a prioridade no atendimento de despesas supérfluas ou não essenciais, em detrimento daquelas, o que racionalmente é quase impossível de se verificar. Se efetivamente não há recursos para o atendimento das prestações inseridas no mínimo existencial, como justificar a destinação para outras despesas? Ademais, o Estado brasileiro dispõe de diversos instrumentos para angariar recursos públicos para custear o fornecimento de tais prestações, como adiante será analisado.

Do exposto, conclui-se que a ponderação entre o princípio da reserva do possível e o direito fundamental veiculado por um princípio colidente que protege posições jurídicas prima facie, as quais demandam prestações positivas estatais, é juridicamente necessária. Mas, quando se tratar de prestações referentes ao mínimo existencial, a ponderação é afastada por não haver posição jurídica prima facie passível de ser restringida. Portanto, pode-se afirmar que a exigência de proteção do mínimo existencial constitui uma restrição à aplicação do principio da reserva do possível. Defende-se que, quanto mais a prestação requerida afastar-se do mínimo existencial, tanto maior será o grau de certeza em relação à confiabilidade epistêmica das premissas jurídicas que corroboram a prevalência do princípio da reserva do possível em sua ponderação.

\subsubsection{O núcleo essencial e outras posições jurídicas definitivas de direitos}

A proteção ao núcleo essencial dos direitos fundamentais também é definida pela doutrina como uma restrição à aplicação do princípio da reserva do possível. O núcleo essencial dos direitos fundamentais consiste em um conteúdo mínimo irredutível de cada direito fundamental, "cuja restrição está fora do alcance do legislador ou do próprio intérprete, num eventual juízo de ponderação" (MARTINS, 2020, p. 196). A ideia de intangibilidade de 
um núcleo essencial dos direitos fundamentais começa a ser delineada na dogmática jurídicoconstitucional na última metade do século XX. Objetiva impor limites às normas restritivas dos direitos fundamentais e evidencia que um espaço de decisão é retirado da discricionariedade de conformação do legislador (MARTINS, 2020, p. 196).

Semelhantemente à garantia do mínimo existencial, a proteção ao núcleo essencial, na Constituição brasileira não é expressa por regra específica, muito embora haja vedação de o poder reformador adotar alterações no texto constitucional tendentes a abolir direitos fundamentais. No entanto, a regra constitucional que confere status de cláusula pétrea às normas de direitos fundamentais (BRASIL, 1988, art. 60, inc. IV) não se confunde com proteção ao núcleo essencial de um direito fundamental. Ou seja, pode-se constatar uma violação ao núcleo essencial de um direito fundamental ainda que esse direito fundamental não seja suprimido ou abolido pelo Poder Reformador Derivado.

Em relação à proteção do núcleo essencial dos direitos fundamentais coexistem diversas teorias. Dentre as que mais relevância possuem para o tema, cita-se a teoria absoluta e a teoria relativa. Em apertada síntese, a teoria absoluta propõe a possibilidade de se extrair de uma análise abstrata da norma, independente do caso concreto, o conteúdo do núcleo essencial de cada direito fundamental (Wesensghalt). Esse conteúdo seria intangível e estaria protegido, inclusive, de qualquer juízo de proporcionalidade (MARTINS, 2020, p. 196-197).

Por sua vez, a teoria relativa admite que possam existir razões mais importantes que autorizem uma intervenção no núcleo essencial de um direito fundamental. Contudo, quanto mais um princípio é restringido, aproximando essa restrição do seu núcleo, mais resistente ele fica às razões contrapostas. Assim, é exigida uma força sobreproporcional a essas razões quando contrapostas à proteção do núcleo essencial. Segundo Alexy, haveria condições em que é possível se afirmar que nenhum princípio colidente prevalece. Assim, "a segurança da proteção é tão grande que, em condições normais, é possível falar em proteção absoluta" (ALEXY, 2015, p. 301).

O problema apontado por Virgílio Afonso da Silva é que:

Nos casos dos direitos fundamentais garantidos por normas ditas de eficácia limitada, sobretudo no caso dos direitos sociais, parece também ser muito difícil analisar qual poderia ser o seu conteúdo essencial. Isso porque, em geral, essas são normas que, segundo os modelos tradicionais, dependem de regulamentação e intervenção estatal para iniciar a sua produção de efeitos. Via de regra, nem mesmo se cogita falar em restrição a tais direitos, já que se ocupa a doutrina, nesses casos, de algo que parece ser anterior à possibilidade de restrição, que é a própria criação de condições para que eles produzam algum efeito. Se tais normas, a partir do texto 
constitucional, não dispõem de quase nenhuma condição de produzir efeitos, não faria sentido restringir a sua eficácia, pois pouco ou nada há de ser restringido. Aqui, também, fica difícil pensar em um conteúdo essencial absoluto ou relativo (SILVA, 2006, p. 47).

Não obstante, a aplicabilidade imediata prevista às normas de direitos fundamentais vai exigir que uma eficácia mínima seja possível e, para tanto, a identificação de um conteúdo mínimo desses direitos se faz necessária, independentemente da conformação do legislador. Caso contrário, haveria uma supremacia da norma infraconstitucional em relação à norma constitucional que confere a proteção ao direito fundamental. Assim, a proteção ao núcleo essencial também independe da plena conformação do legislador orçamentário para ser reconhecida como constitucionalmente devida.

Adiar-se injustificada e indefinidamente a concretização de um direito fundamental, sem que o Estado assegure, ao menos, o núcleo essencial da norma de direito fundamental ${ }^{57}$, é desconsiderar o caráter normativo e vinculativo das normas de direitos fundamentais, para relegá-las a um caráter meramente simbólico. Atribuir às normas de direitos fundamentais uma máxima eficácia e efetividade é ideia reguladora que deve orientar a ação de todos os poderes constituídos e de "todos os órgãos estatais, no âmbito de suas respectivas competências, dever ao qual se soma o dever de aplicação direta de tais normas por partes dos órgãos do Poder Judiciário" (SARLET, 2017a, p. 601-602). Esses encargos somente poderiam ser afastados mediante necessária, adequada e suficiente justificação. Essa também foi, como visto, a preocupação extraída das decisões do Tribunal Constitucional Federal da Alemanha.

Muito embora o dever de proteção do núcleo essencial não seja absoluto, ele pode atuar, no caso concreto, como razões para afastar a prevalência do princípio da reserva do possível sobre o principio colidente. Isso porque, na medida em que o princípio da reserva do possível busca otimizar a razoabilidade da prestação requerida pelo particular a partir das possibilidades orçamentárias que também exige razoabilidade em sua alocação, o dever de proteção do núcleo essencial vai impor argumentativamente uma justificação que apresente razões muito mais fortes para que este se demonstre a razoabilidade de uma alocação orçamentária que possa prevalecer em detrimento da proteção do núcleo essencial de um

\footnotetext{
${ }^{57}$ A teoria relativa do conteúdo essencial, adotada por Robert Alexy, embora admita que possam existir razões mais importantes que autorizem uma intervenção no conteúdo essencial de um direito fundamental, por outro lado afirma que quanto mais um princípio fica restringido, mais ele fica resistente. Assim a força das razões contrapostas à proteção do conteúdo mínimo cresce de forma sobreproporcional e há condições em que é possível se afirmar que nenhum princípio colidente prevalecerá. Assim, a segurança da proteção é tão grande que, em condições normais, é possível falar em proteção absoluta (ALEXY, 2015, p. 301).
} 
direito fundamental.

A jurisprudência do STF também reafirma, por diversas vezes, a primazia em se assegurar o núcleo essencial dos direitos fundamentais, inclusive afastando o argumento da discricionariedade para justificar a omissão estatal nesta seara, bem como afasta o princípio da reserva do possível como argumento suficiente para justificar o adiamento da efetivação de medidas que garantam proteção que envolva o núcleo essencial dos direitos fundamentais ${ }^{58}$.

Conforme já esclarecido, a reserva do possível, como princípio jurídico, não incide sobre posições jurídicas definitivas. Assim, se a jurisprudência vinculante já tiver reconhecido a definitividade de certas posições jurídicas, estabelecendo uma regra de precedência entre certa posição jurídica subjetiva e a reserva do possível, deve-se reconhecer que essas posições jurídicas também constituirão, ao lado do mínimo existencial, uma restrição à aplicação do princípio da reserva do possível.

Pode-se constatar na jurisprudência do STF que, além do mínimo existencial, outros direitos tiveram sua precedência assinalada em relação ao princípio da reserva do possível. Em alguns casos, afastou-se, de plano, a possibilidade de ponderação do princípio com o direito requerido pelo indivíduo. No âmbito do Supremo Tribunal Federal, em sede de recurso extraordinário e com repercussão geral reconhecida, os direitos que se encontram nesta condição, dentro do recorte temporal da pesquisa, foram: a) o direito líquido e certo à reparação de anistiados políticos ${ }^{59}$; b) o direito fundamental ao benefício assistencial (BRASIL, 1988, art. 203, inc. V) ${ }^{60}$, inclusive para estrangeiros residentes no país; d) o direito fundamental de proteção à integridade física, psíquica e moral dos presos (BRASIL, 1988, art. $\left.5^{\mathrm{o}}, \mathrm{XLIX}\right)^{61}$; e) a garantia de acessibilidade de pessoas com deficiência ${ }^{62}$.

\footnotetext{
${ }^{58}$ A inoponibilidade do argumento da discricionariedade ante o dever de garantia do núcleo essencial é afirmada na jurisprudência do STF, a exemplo da assertiva extraída do voto do Ministro Ricardo Lewandoski, no Recurso Extraordinário no 592.581/RS quando assevera: “A reiterada omissão do Estado brasileiro em oferecer condições de vida minimamente digna aos detentos exige uma intervenção enérgica do Judiciário para que, pelo menos, o núcleo essencial da dignidade da pessoa humana lhes seja assegurada, não havendo margem para qualquer discricionariedade por parte das autoridades prisionais no tocante a esse tema" (STF, 2015, p. 45) No mesmo sentido, o Ministro Barroso chama a atenção para que "não é a reserva do possível um aspecto suficiente para postergar obrigações que envolvam o núcleo essencial dos direitos fundamentais, aos quais corresponde a dignidade da pessoa humana" (Ibid, p. 98).

${ }^{59}$ Vide: Recurso Extraordinário 553.710/DF e Recurso Extraordinário no ${ }^{\circ}$ 580.963/PR.

${ }^{60}$ Vide Recurso Extraordinário n ${ }^{\circ} 567.985 / \mathrm{MT}$

61 Vide Recurso Extraordinário ${ }^{\circ}$ 580.252/MS e Recurso Extraordinário $\mathrm{n}^{\circ}$ 592.581/RS. Em ambos os casos direito foi associado ao mínimo existencial, por estar intimamente ligado à dignidade humana dos presos. Foi consignado, ainda, que se trata de um direito amplamente regulamentado em leis infraconstitucionais, como a Lei de Execuções Penais. Segundo o trecho destacado da decisão: "Contraproducente se revela a alegação da reserva do possível, pois o Estado não pode se furtar a garantir, minimamente, o conteúdo normativo dos direitos especificados ao longo do Texto Constitucional e exaustivamente regulamentado pelas normas infraconstitucionais, sob pena de incorrer em ilegitimidade" (STF, 2015, p. 90).
} 
Essas posições jurídicas ainda estão sendo sedimentadas pela jurisprudência do STF no âmbito de processos em que a repercussão geral foi reconhecida. Em alguns casos, apresentaram força de precedente, como na decisão que definiu a prevalência do direito líquido e certo à reparação de anistiados políticos, mudando a orientação que as turmas do STJ vinham adotando sobre o tema.

Sarlet (2017b, p. 1) chama a atenção para a tendência que se manifesta nas decisões do Supremo Tribunal Federal em interpretar de forma mais extensiva o reconhecimento de direitos subjetivos originários a prestações fáticas estatais. Ao analisar a decisão proferida pelo Tribunal Constitucional Federal da Alemanha, em maio de 2017, em sede de ação de reclamação constitucional, na qual o tribunal reafirmou a possibilidade de reconhecimento de que um direito subjetivo originário a prestações inseridas no direito à saúde, o autor adverte para o fato de que esse reconhecimento pelo tribunal alemão, reveste-se de caráter excepcional, incidindo quando se tratar de "uma situação de grave risco para a vida humana e quando inexistir no catálogo de procedimentos e tratamentos do seguro público de saúde uma alternativa compatível”, assemelhando-se a uma situação de estado de necessidade. Nesses casos, seria razoável exigir um meio alternativo de tratamento que tivesse alguma possibilidade de assegurar uma melhora do quadro clínico do paciente/requerente. Em suas palavras:

[...] a decisão do TCF, sumariamente apresentada, não parece estar tão distante da prática jurisprudencial brasileira, em especial do STF, pois este, em reiterados julgados (rememore-se aqui o paradigma da STA 175, julgada em março de 2010), afirma que o reconhecimento de direitos subjetivos originários a prestações assume caráter excepcional, justificando-se apenas quando verificado risco de vida ou violação do assim chamado mínimo existencial, vedando apenas medicamentos de caráter experimental. Além disso, o STF — nos casos referidos — afasta a objeção da reserva do possível nas suas diversas manifestações, valendo-se do critério do mínimo existencial e da proibição de proteção insuficiente para efeitos da ponderação nos casos concretos (SARLET, 2017b, p. 1).

No entanto, Sarlet destaca que, diferentemente da Alemanha, onde se impõe exegese restritiva a tais exceções, "no Brasil o caminho tem sido o oposto, pois as 'exceções' se multiplicam" abrangendo não se restringindo à "distinção entre medicamentos novos e

62 Vide: Agravo Regimental no Recurso Extraordinário com Agravo 1.189.014/SP. Precedentes citados nesta decisão que dão prevalência ao direito pleiteado: Agravo de instrumento $\mathrm{n}^{\circ}$ 455.802/SP, Agravo de instrumento $\mathrm{n}^{\mathrm{o}}$ 475.571/SP - Agravo em Recurso Extraordinário ${ }^{\circ}$ 698.258/SP, Recurso Extraordinário $\mathrm{n}^{\circ}$ 401.673/SP, Agravo em Recurso Extraordinário no 410.715/SP, Recurso Extraordinário n ${ }^{\circ} 411.518 / \mathrm{SP}$, Recurso Extraordinário ${ }^{\circ}$ 436.996/SP e outros. 
experimentais", mas incluindo outros critérios "além do mínimo existencial e da proibição de proteção insuficiente, eventualmente do risco de vida" (SARLET, 2017b, p. 1). Embora tal preocupação tenha sua relevância, há que se considerar, como já destacado por Andreas Joachim Krell (2002, p. 51), que o contexto social e econômico, bem como o nível de concretização dos direitos fundamentais, em ambos países, são bastante diferentes, principalmente em relação à efetivação do mínimo existencial, o que poderia, em tese, explicar a maior tendência ao reconhecimento de direitos subjetivos a prestações fáticas pela corte constitucional brasileira.

A identificação das "posições definitivas" fixadas em precedentes implica no reconhecimento de uma regra jurídica a ser aplicada em casos semelhantes e pode ser extraída das regras J.13 e J.14 da Teoria Argumentação Jurídica formulada por Robert Alexy, relativas ao uso de precedentes, as quais determinam: “(J.13) Quando se puder citar um precedente a favor ou contra uma decisão deve-se fazê-lo. (J.14) Quem quiser afastar-se de um precedente, assume a carga da argumentação" (ALEXY, 2017, p. 262). Dessas regras, pode-se inferir que quando uma relação de precedência for estabelecida em um precedente judicial, sob determinadas circunstâncias, tais posições definitivas constituirão uma norma jurídica a ser aplicada em casos semelhantes ${ }^{63}$.

Chama-se, ainda, a atenção ao teor da lei de colisão, que estabelece que "as condições sob as quais um princípio tem precedência em face de outro constituem o suporte fático de uma regra que expressa a consequência jurídica do princípio que tem precedência”. Isto é, a lei de colisão diz respeito às condições fáticas do caso concreto, as quais se apresentam como suporte fático da regra que tem a consequência jurídica do princípio precedente como sua própria consequência jurídica. Se essas condições fáticas que ensejaram a prevalência do princípio da reserva do possível em relação a um princípio de direito fundamental estiverem delineadas em precedentes judiciais também deverão ser consideradas na aplicação em casos semelhantes ao precedente invocado. A consideração das regras da teoria da argumentação jurídica poderá orientar o intérprete para estabelecer o grau de confiabilidade epistêmica normativa, quando os mesmos fundamentos jurídicos forem invocados e estiverem presentes circunstâncias fáticas semelhantes. Como regra, estabelecerão critérios na ponderação do princípio da reserva do possível, garantindo uma coerência conceitual com a teoria adotada nesta pesquisa.

63 Alexy (2017, p.262) afirma que "o uso de um precedente significa a aplicação da norma que subjaz à decisão do precedente". 


\subsubsection{O princípio da máxima aplicação dos recursos}

O princípio da aplicação do máximo dos recursos disponíveis foi inicialmente previsto no artigo $2^{\circ}$ do Pacto Internacional de Direitos Econômicos, Sociais e Culturais da ONU (1966) e reiterado no Protocolo de San Salvador, de 1988. Sgarbossa (2010, p. 320) explica que o princípio impõe um dever de que os Estados-parte apliquem, na realização dos direitos econômicos, sociais e culturais, o máximo dos recursos disponíveis, a título próprio ou mediante cooperação internacional. Assim, só haveria o cumprimento desse dever, se, fosse devidamente comprovada a aplicação do máximo dos recursos disponíveis para a efetivação dos direitos econômicos, sociais e culturais (SGARBOSSA, 2010, p. 319-320).

O princípio impõe, portanto, a otimização na utilização dos recursos públicos destinados às prestações de direitos fundamentais, dentro dos recursos disponíveis ao Estado. Esse princípio guarda, ainda, consonância com a paradigmática decisão Numerus Clausus I, do Tribunal Constitucional Federal alemão, na medida em que, para decidir sobre a existência do direito definitivo dos autores das ações, aquela corte perquiriu se o Estado havia implementado todos os esforços necessários para a concretização do direito pleiteado. $\mathrm{Na}$ decisão consignou-se que o Estado já estava fazendo o máximo possível para tornar o ensino superior acessível, esgotando seus esforços.

Afirmar que os recursos públicos devem ser empregados no patamar máximo disponível para a efetivação dos direitos fundamentais sociais requer um exame do orçamento, tanto pelo aspecto da despesa quanto da receita. Do lado da despesa, implica a análise do emprego dos recursos sob o aspecto quantitativo e qualitativo. Sob a ótica da receita, vai exigir, por exemplo, a análise da existência de concessões e prorrogações de isenções fiscais, desproporcionais, não justificadas, ou ainda da inércia na cobrança de débitos fiscais, em desacordo com os parâmetros da Lei de Responsabilidade Fiscal, do contingenciamento indevido de recursos de fundos. Pode-se afirmar que essa análise implica a necessidade de adoção de critérios jurídicos racionais de aferição das alocações orçamentárias.

Ainda que ao legislador seja reservada uma margem considerável de discricionariedade na alocação dos recursos públicos, essa discricionariedade encontra limites constitucionais. Assim, o princípio da máxima aplicação dos recursos fornece importante diretriz para análise do caso concreto e que pode auxiliar o intérprete a aferir a confiabilidade epistêmica da premissa empírica do princípio da reserva do possível (ou seja, a escassez). 
Caso não seja comprovado que o Estado empreendeu os esforços necessários para a obtenção e destinação do máximo de recursos disponíveis ou potencialmente possíveis de serem auferidos para custear a prestação requerida, sem comprometer outros interesses igualmente relevantes, a confiabilidade epistêmica da premissa empírica do princípio (escassez) é mitigada.

A conexão do princípio da reserva do possível com o princípio da máxima aplicação dos recursos pode se explicar da seguinte forma. O princípio da reserva do possível exige a otimização da razoabilidade da prestação pleiteada pelo particular. Assim, a determinação daquilo que é razoável o indivíduo exigir da sociedade tem como um dos parâmetros a escassez de recursos. Por sua vez, a escassez de recursos também exige alocações racionais e razoáveis. A exigência de razoabilidade das alocações implica, além das considerações pertinentes à legalidade e à moralidade administrativa, verificar se os escassos recursos estão sendo destinados às prestações prioritárias. Assim, razoável será a alocação efetuada em observância ao princípio da máxima aplicação dos recursos na efetivação dos direitos fundamentais. Como princípio jurídico incorporado ao ordenamento pátrio, caberá ao Poder Público o ônus de provar que empreendeu todos os esforços de forma prioritária, no cumprimento do dever de efetivação dos direitos fundamentais ou de apresentar razões fortes e suficientes para que não tenha procedido dessa forma. Quando isso não ocorrer, haverá margem de dúvida quanto à ocorrência ou não de efetiva escassez de recursos públicos que inviabilize a oferta da prestação pleiteada e autorize a incidência do princípio da reserva do possível, pela dúvida quanto à efetiva escassez dos recursos públicos.

As medidas adotadas pelo Poder Público, além de adequadas e necessárias, devem ser suficientes. Essa análise leva em conta aspectos quantitativos e qualitativos do agir estatal para a verificação da desincumbência dos deveres de proteção que lhe cabem. O aspecto quantitativo refere-se ao universo dos titulares dos direitos fundamentais atendidos e o aspecto qualitativo volta-se à verificação se "a atuação estatal é eficiente e eficaz na tutela de tais direitos, ou se, contrariamente, a despeito do agir estatal, os direitos continuam em grande medida irrealizados" (SGARBOSSA, 2010, p. 286-287). Dessa forma, a ideia da máxima aplicação dos recursos é associada à verificação da proibição da proteção deficiente (Untermaß Verbot).

A suficiência da prestação ofertada é exigida tanto em termos tanto qualitativos quanto quantitativos. Quanto menos recursos empregados e/ou mais deficiente a prestação ofertada para a efetivação de um direito fundamental, tanto mais fortes deverão ser as razões para 
justificar a prevalência do princípio da reserva do possível em relação ao princípio colidente. Isso porque ao Estado Democrático de Direito, que declara direitos fundamentais, é vedado adotar medidas insuficientes para a proteção constitucionalmente determinada a tais direitos, inclusive alocar recursos insuficientes sem justa motivação, ainda mais quando o mínimo existencial ainda não está garantido a todos os cidadãos. SGARBOSSA (2010, p. 285), relembra as lições de Canotilho o qual, com base em Claus Wilhelm-Canaris, afirma que "o Untermaß Verbot implica a verificação da existência de condições mínimas de eficiência na proteção, bem como na aferição de inexistir sobreavaliação no que se refere aos bens jurídicos e aos interesses contrapostos ". Corroborando essa afirmação, o autor também traz as asserções de Paulo Gilberto Cogo Leivas sobre a compreensão da proibição de nãosuficiência:

\begin{abstract}
A proibição da não-suficiência exige que o legislador [e também o administrador], se está obrigado a uma ação, não deixe de alcançar limites mínimos. O Estado, portanto, é limitado de um lado, por meio dos limites superiores da proibição do excesso, e de outro, por meio de limites inferiores da proibição da não-suficiência. Como afirma Borowski: "A melhor realização possível do objeto da otimização dos princípios jusfundamentais-prestacionais é um objetivo prescrito pela constituição". (LEIVAS, apud SGARGOSSA, 2010, p. 282).
\end{abstract}

Assim, a utilização máxima dos recursos está associada à ideia da proibição da proteção deficiente. Sob essa ótica exige tanto a alocação de recursos quantitativamente suficientes, quanto qualitativamente, com a adoção de medidas materiais e normativas adequadas e suficientes para a proteção do direito fundamental. E as razões para justificar a priorização de outros interesses devem ser suficientemente fortes para que a deficiência da proteção estatal não seja uma omissão indevida e inconstitucional.

Sgarbossa (2010, p. 322) defende também que a interpretação do que seriam "recursos disponíveis" se dê no sentido da verificação da integralidade dos recursos orçamentários e a análise da proporção da distribuição dos recursos entre áreas não prioritárias e o montante das verbas destinado direta e efetivamente a programas sociais voltados à realização dos direitos fundamentais a prestações ${ }^{64}$. O autor rechaça o entendimento de que o total dos recursos disponíveis se refere somente ao montante alocado em cada rubrica, individualmente.

64 Para Sgarbossa: “[...] a expressão máximo dos recursos disponíveis, a despeito da indeterminação, serve de parâmetro hermenêutico mínimo de determinação de sentido, de modo a indicar que a parcela de recursos alocada para a consecução dos direitos econômicos, sociais e culturais deve ser significativa em comparação com as alocadas para outras finalidades, não assim írrita, ínfima ou muito diminuta, em montante que, comparativamente, possa demonstrar sua efetiva prioridade” (SGARBOSSA, 2010, p. 321-322). 
A comprovação de que o máximo de recursos foi destinado para a implementação dos direitos fundamentais, demanda não somente a verificação de que existe a destinação na lei orçamentária dos recursos para determinada finalidade. É necessário verificar também não haver a indisponibilidade desses recursos em razão de contingenciamentos imotivados ou com motivação desviante ou insuficiente. O contingenciamento de recursos orçamentários é feito por meio de ato administrativo e tem sua previsão na Lei de Responsabilidade Fiscal (BRASIL, 2000, LC n ${ }^{\circ}$ 101) somente em duas situações. A sindicância pelo Poder Judiciário da motivação e da legalidade do ato administrativo é juridicamente admitida. Em termos argumentativos, as razões para que um ato administrativo possa obstar a efetividade de um direito previsto em norma constitucional, cujos recursos foram aprovados pelo parlamento, devem possuir relevante força para justificar aquela intervenção.

Afirmar a máxima utilização dos recursos também demanda verificar se as possibilidades de flexibilização (transposição/remanejamento/transferências) das verbas orçamentárias são ou não admitidas. Em caso negativo, está comprovado o esgotamento de todas as possibilidades orçamentárias para o atendimento do direito fundamental.

Sob a ótica da receita, a máxima utilização dos recursos torna questionável a concessão de renúncias fiscais ${ }^{65}$ ou de benefícios de natureza tributária ou, ainda, a ausência de cobrança de valores inscritos na dívida ativa, principalmente quando associada à decretação recorrente de estado de calamidade pública pelo ente federativo. Essa situação pode agravar o endividamento público e diminuir o montante disponível para a concretização dos direitos fundamentais, em benefício de determinados setores. É, portanto, admissível ao Poder Judiciário a sindicância de ilegalidades orçamentárias, quando devidamente provocado, bem como para a determinação do que se entende juridicamente razoável em termos orçamentários apto a limitar uma prestação de direito fundamental.

Nesse aspecto, Élida Graziane Pinto (2017, p. 2-3) chama atenção para a necessidade do controle sobre a concessão de renúncias fiscais, sem lastro na correspondente medida compensatória, sobretudo as que são concedidas por prazo indeterminado. A autora esclarece que a Lei de Responsabilidade Fiscal (BRASIL, 2000, LC $\mathrm{n}^{\mathrm{o}}$ 101) exige no caput e no parágrafo $2^{\circ}$ do artigo 14 que a validade e o início da vigência da renúncia fiscal sejam condicionados à instituição efetiva de medida compensatória, com duração de três anos

${ }^{65}$ Segundo o $\S 1^{\circ}$ do artigo 14, da Lei Complementar $n^{\circ}$ 101/2000 (Lei de Responsabilidade Fiscal) renúncia compreende: "[...] anistia, remissão, subsídio, crédito presumido, concessão de isenção em caráter não geral, alteração de alíquota ou modificação de base de cálculo que implique redução discriminada de tributos ou contribuições, e outros benefícios que correspondam a tratamento diferenciado" (BRASIL, 2000, LRF). 
(exercício de instituição e nos dois seguintes) A ainda parcialmente vigente Lei Geral de Licitações e Contratos, Lei $n^{\circ}$ 8.666/1.993 veda expressamente a celebração de contratos com prazo de vigência indeterminado, que gerassem obrigações de gasto para o Estado ad aeternum $^{66}$. Portanto, a ausência de revisão do impacto orçamentário das renúncias fiscais, após o prazo previsto no artigo 14 da LRF, violando também o determinado no artigo 57, parágrafo $3^{\circ}$ da Lei $n^{\circ} 8.666 / 1993$ pode ser verificada para a formação do juízo de confiabilidade epistêmica quanto à efetiva existência de escassez de recursos públicos.

Não se defende que o Judiciário, no âmbito da análise da verificação da existência de escassez deva interferir nas decisões alocativas tomadas pelo Legislativo, substituindo-as por suas próprias decisões. O que se defende é que não constatação da utilização dos recursos disponíveis, de forma a não maximizar sua aplicação na concretização dos direitos fundamentais comparativamente a outras áreas não prioritárias, prejudica o juízo sobre o grau de confiabilidade epistêmica da premissa empírica do princípio da reserva do possível, por enfraquecer a força epistêmica do argumento da escassez de recursos. Esse ponto será melhor explicitado nos capítulos a seguir.

Em $1^{\circ}$ de abril de 2021, foi publicada a Lei ${ }^{\circ}$ 14.133/2021 que passa a disciplinar as licitações e contratos administrativos. O artigo 193, II da referida lei, dispõe que a Lei $n^{\circ}$ 8.666/93 terá sua vigência revogada somente no prazo de 2 anos após a publicação na nova lei. Estabelece, ainda, em seu artigo 193, I a revogação imediata dos artigos 89 a 108 que trata dos crimes e das penas cominadas às condutas descritas na lei revogada que passam a ser disciplinados no Código Penal. Assim, os artigos citados ainda estão vigentes por ocasião da elaboração da presente pesquisa. A nova Lei de Licitações e Contratos Administrativos prevê, como regra, a duração decenal dos contratos sem investimento e 35 anos como investimento, sendo o contrato por prazo indeterminado restrito à hipótese do artigo 109, da referida lei. 


\section{ASPECTOS JURÍDICO-ORÇAMENTÁRIOS DO PRINCÍPIO DA RESERVA DO POSSÍVEL}

No capítulo anterior, foi abordada a relação entre o princípio da reserva do possível e os direitos fundamentais. Extrai-se dessa análise que todos os direitos fundamentais, em alguma medida, demandam prestações positivas estatais, sejam elas materiais ou normativas. Sob o aspecto econômico ou pragmático, demonstrou-se não haver razões plausíveis para se limitar a possibilidade de colisão do princípio da reserva do possível somente com normas que veiculam direitos fundamentais sociais. Isso porque qualquer norma de direito fundamental que demandar para sua concretização a oferta de prestações materiais estatais, sejam elas assecuratórias de direitos fundamentais sociais ou individuais, vão exigir o aporte de recursos públicos e as devidas alocações orçamentárias, não havendo razões para que não estejam submetidas ao juízo de razoabilidade que o princípio da reserva do possível impõe às prestações pleiteadas pelo particular à sociedade.

Em consonância com a teoria dos princípios formulada por Robert Alexy, o princípio da reserva do possível, ao ser submetido a um juízo de ponderação com um princípio de direito fundamental, pode resultar em restrições às possibilidades jurídicas, externas ao conteúdo assegurado prima facie pela norma colidente. Por outro lado, o princípio da reserva do possível, como um mandamento de otimização, também vai admitir restrições naquilo que assegura prima facie. Dentre as restrições que a doutrina aponta ao princípio da reserva do possível foram relacionadas aquelas consideradas mais pertinentes ao objeto desta pesquisa. Em relação à possibilidade de restrição na dimensão jurídica do princípio da reserva do possível, destacaram-se o mínimo existencial; a proteção ao núcleo essencial dos direitos fundamentais e outras posições definitivas fixadas em precedentes judiciais, os quais têm a consequência de afastar a possibilidade de ponderação do princípio, por constituírem posições definitivas já reconhecidas pelo ordenamento jurídico. Por sua natureza, posições definitivas não estão sujeitas à ponderação e, por tal razão, não terão seu conteúdo afetado por eventuais restrições que o princípio da reserva do possível impõe a normas cujos mandamentos possuem natureza prima facie. Em relação à dimensão fática do princípio, foi identificada exigência da máxima utilização dos recursos, consagrada no Pacto Internacional de Direitos Econômicos, Sociais e Culturais, da ONU (1966) e reiterada no Protocolo de San Salvador (1988). A exigência de otimização/maximização dos recursos a serem utilizados na concretização dos direitos fundamentais pode auxiliar na aferição da efetiva existência de 
escassez de recursos, mesmo ante alocações orçamentárias distribuídas de forma razoável, em respeito aos direitos fundamentais. A escassez de recursos limita as possibilidades fáticas de concretização de prestações materiais de direitos fundamentais exigíveis pelo particular e, por via de consequência, orienta o juízo da razoabilidade dessa prestação.

Reconhecer que a concretização dos direitos fundamentais é condicionada pela escassez de recursos públicos para o atendimento das prestações, implica inferir que, somente a partir da demonstração da inexistência ou insuficiência de recursos para o atendimento dessas prestações e da ponderação dos princípios colidentes é que será possível ao intérprete extrair o que é definitivamente e razoavelmente devido ao indivíduo ${ }^{67}$. Assim, a escassez passa a constituir uma condicionante das possibilidades fáticas. Ou seja, a escassez será a premissa empírica subjacente à aplicação do princípio da reserva do possível.

A escassez de recursos públicos pode estar relacionada tanto à inexistência/insuficiência fática de recursos públicos, quanto decorrer da ausência de autorização orçamentária para determinado gasto em particular. A partir dessa constatação, a doutrina aponta que o princípio da reserva do possível apresentaria duas dimensões: uma fática e outra jurídica (BARCELLOS, 2011, p. 278). Entretanto, essa abordagem doutrinária decorre da identificação quase total do princípio da reserva do possivel com a escassez de recursos, acarretando esse tipo de conclusão.

Importa esclarecer que na abordagem já consagrada na doutrina analisada, o que se denomina de "dimensão jurídica" do princípio da reserva do possível - no sentido da indisponibilidade orçamentária de determinado recursos públicos, decorrente de opções alocativas do legislador e do administrador - inexoravelmente incidirá sobre as possibilidades fáticas de atendimento à prestação, ou seja, sobre a quantidade de recursos disponíveis e não sobre as possibilidades jurídicas de aplicação do princípio. Em consonância com a teoria dos princípios alexyana, a determinação das possibilidades jurídicas do que é definitivamente devido ao indivíduo é obtida na ponderação, pela consideração dos princípios colidentes, e protege o direito fundamental.

Parece, pois, mais adequado considerar que a ausência/insuficiência de autorização orçamentária para determinado gasto está relacionada ao nível de escassez de recursos, que é a premissa fática subjacente ao princípio da reserva do possível e não à dimensão jurídica do

67 No mesmo sentido: "Nesse contexto, a razoabilidade de uma exigência feita por um indivíduo à coletividade é influenciada pela quantidade de recursos efetivamente disponível (a qual termina por ser uma função da capacidade contributiva da população, da renda gerada por sua atividade produtiva) e pelas preferências que essa sociedade exprime no processo orçamentário” (MARINO, 2015, p. 173). 
princípio. Em outras palavras, o que se tem atribuído como dimensões fática e jurídica do princípio da reserva do possível, em verdade, refere-se somente a sua possibilidade fática. A escassez de recursos é que pode resultar de causas econômicas ou reais, ou ter natureza normativa, decorrente de decisões jurídico-valorativas orçamentárias que modelam as prioridades de alocação dos recursos públicos. Portanto, não se coaduna com a teoria dos princípios de Alexy atribuir como dimensão jurídica do princípio a indisponibilidade dos recursos pela decisão política de alocação orçamentária do legislador de não contemplar o suficiente para o atendimento às prestações de direitos fundamentais. Embora a alocação orçamentária se materialize por meio de leis e atos jurídicos, sua consequência é determinar a inexistência ou insuficiência de recurso (escassez de recursos) e não uma restrição jurídica à aplicação do princípio.

Esclarecido o entendimento a ser adotado nesta pesquisa sobre as dimensões do princípio da reserva do possível, passa-se à análise de alguns aspectos econômicos, jurídicos e orçamentários que permeiam a compreensão da escassez de recursos e o princípio da reserva do possível.

\subsection{O PRINCÍPIO DA RESERVA DO POSSÍVEL E A ESCASSEZ DE RECURSOS}

Embora a norma jurídica atue no âmbito do dever ser e, em alguns casos, destine-se a promover uma alteração da própria realidade, um comando jurídico pode-se tornar irrealizável pela ausência de condições materiais para sua concretização (BARCELLOS, 2011, p. 276). Assim também, em relação às possibilidades fáticas que permeiam a ponderação do princípio da reserva do possível, é preciso considerar as condições materiais e financeiras estatais que a realidade impõe como limite para a realização dos comandos normativos constitucionais. Isso significa, em termos práticos, perquirir a confiabilidade da alegação da existência ou não de recursos disponíveis para o atendimento das prestações positivas demandas do ente estatal. Tal procedimento é necessário porque pode fornecer ao intérprete da norma um parâmetro para dimensionar exigência da razoabilidade do que o particular está exigindo do Estado no caso concreto.

A alegada escassez que justifica o não atendimento da prestação requerida pelo particular pode ter causas e extensão diversas e, portanto, as consequências jurídicas também podem ser diversas. A escassez de recursos constitui fato jurídico a ser provado pela parte que o alegou em uma ação judicial. Para melhor compreensão do que se refere a afirmar a 
escassez dos recursos públicos, serão feitas considerações específicas para o contexto do Estado brasileiro, sobre alguns aspectos que envolvem a inexistência fática dos recursos públicos (exaustão orçamentária ou dimensão fática) e da escassez que decorre da escolha alocativa dos recursos públicos (dimensão jurídica) por parte dos gestores públicos.

\subsubsection{A dimensão fática: escassez fática de recursos ou exaustão orçamentária}

A análise da escassez, em sua dimensão fática, traz à tona a necessidade de o Direito se valer de outras ciências para a compreensão de um fenômeno empírico que foi tornado jurídico. Esse reconhecimento tem relevância quando se constata a constante utilização de argumentos empíricos para a justificação da omissão ou impossibilidade estatal em ofertar prestações materiais aos indivíduos relacionadas ao conteúdo de direitos fundamentais. A importância do tema se relaciona à análise da confiabilidade da premissa empírica do princípio da reserva do possível.

Em termos gerais, dizer que um bem é escasso significa afirmar que ele não existe em quantidade suficiente para satisfazer a todas as necessidades de sua utilização. A escassez também pode se apresentar em vários graus e por causas diferenciadas. Sobre essa gradação, Martins relembra a classificação de Jon Elster, o qual afirma que a escassez pode ser natural (que se divide em severa ou suave), quase natural ou artificial. E esclarece:

\footnotetext{
A escassez natural severa aparece quando não há nada que alguém possa fazer para aumentar a oferta. Pinturas de Rembrandt são um exemplo. A escassez natural suave ocorre quando não há nada que se possa fazer para aumentar a oferta a ponto de atender a todos. As reservas de petróleo são um exemplo, a disponibilização de órgãos de cadáveres para transplante é outro. A escassez quase natural ocorre quando a oferta pode ser aumentada, talvez a ponto da satisfação, apenas por condutas não coativas dos cidadãos. A oferta de crianças para adoção e de esperma para inseminação artificial são exemplos. A escassez artificial surge nas hipóteses em que o governo pode, se assim decidir, tornar o bem acessível a todos, a ponto da satisfação. A dispensa do serviço militar e a oferta de vagas em jardim da infância são exemplos (MARTINS, 2020, p. 145).
}

Barcellos (2011, p. 278) afirma que, em relação aos recursos auferidos pelo Poder Público, é possível se questionar a realidade dessa espécie de circunstância (a escassez natural), tendo em conta "a forma de arrecadação de recursos e a natureza dos ingressos públicos". Ou seja, como será adiante explicitado, a escassez que se alega para obstar a oferta de determinadas prestações de direitos fundamentais tem mais relação com a escassez do tipo 
artificial, fruto de opções alocativas orçamentárias, do que propriamente de uma escassez natural.

A afirmação de uma impossibilidade fática de realização de um direito fundamental pressupõe a efetiva inexistência/insuficiência de recursos estatais, de forma insuperável, para fazer frente às despesas públicas que concretizam os direitos fundamentais a prestações positivas, em determinado tempo e espaço. Para melhor compreensão da questão, há que se destacar dois aspectos: como o Estado aufere seus recursos e quando, economicamente, ocorreria a escassez fática desses recursos.

Para efetivar os seus gastos, além do poder de tributar e de planejar sua arrecadação, o Estado também pode dispor de receitas próprias, de mecanismos de financiamento público e da emissão de sua própria moeda. Esses instrumentos são complementares e apresentam vantagens e limites.

O primeiro instrumento de que o Estado brasileiro dispõe para a obtenção de recursos é a arrecadação tributária. Para tanto, o Poder Público pode-se valer tanto de aumento da carga tributária pela elevação de alíquotas e pela criação de novos tributos (no caso da União), quanto da utilização de instrumentos de tributação progressiva ${ }^{68}$. Esse último instrumento permite que o Estado aufira maiores receitas sem o consequente aumento da carga tributária, pois tem seu foco naquela parte dos contribuintes com maior capacidade contributiva. Por sua vez, a instituição de tributos ou sua majoração encontra limites na própria Constituição, a exemplo do chamado princípio da anualidade (BRASIL, 1988, art. 150, III), da vedação da utilização da tributação como confisco (BRASIL, 1988, art. 150, IV) e do princípio da capacidade contributiva (BRASIL, 1988, art. 145, $\S 1^{\circ}$ ). As receitas provenientes dos tributos são denominas receitas derivadas.

No Brasil, uma das principais fontes de custeio do gasto público advém dos tributos arrecadados. Identifica-se, contudo, forte limitação dessa fonte de recursos, porque, no Brasil, optou-se por um modelo de tributação regressiva ${ }^{69}$. Célia Lessa Kerstenetzk e Pedro Fandiño

\footnotetext{
${ }^{68}$ A tributação progressiva respeita o princípio constitucional da capacidade contributiva inserido no artigo 145 , $\S 1^{\circ}$, da Constituição e está relacionado com o princípio da isonomia em sua vertente apontada por Álvaro Rodríguez Brejeiro como "igualdade por meio dos impostos" e "que traduz a ideia de tributar mais a quem tem maior riqueza e menos a quem detém menor quantidade dela" (SCAFF, 2018, p. 282).

${ }^{69}$ Para melhor esclarecer: "A classificação de um tributo como regressivo ocorre na medida em que "cresce a onerosidade relativa em razão inversa da capacidade contributiva do contribuinte" (GASSEN, 2009). O sistema tributário brasileiro tem como característica fática e jurídica a regressividade (FERRAZ; GODOI. SPAGNOL, 2014), principalmente em razão da base de tributação se concentrar sobre a produção e o consumo (tributos indiretos), pois a incidência de tais tributos se realiza sobre fatos que pouco dizem sobre a capacidade de pagamento dos indivíduos. Em razão disso, inviabilizam-se mecanismos de diferenciação de cargas tributárias
} 
(2019, p. 325) afirmam que a análise das implicações do modelo tributário constitucional vigente, ajuda a compreender "por que tem sido tão difícil levar a cabo a consolidação dos serviços públicos sociais universais e a redução profunda e sustentável das desigualdades por ela almejados - em outras palavras, a economia política da desigualdade".

Aliado a essa modalidade de tributação regressiva, outro problema que vem minando as possibilidades de receitas do Estado é a concessão pouco criteriosa de isenções fiscais e renúncias fiscais. Emerson Affonso da Costa Moura e Jamil Calili Ribeiro relembram as lições de Frederico Breyner:

\begin{abstract}
Além da forma imprópria para arrecadação dos recursos, a regressividade do sistema pode ser agravada com o retorno social inadequado do uso dos recursos públicos, quando a apropriação dos recursos arrecadados é feita por grupo social diferente daqueles grupos que menos possuem capacidade contributiva. Consideramos neste artigo que tal gasto público deve ser considerado como um gasto regressivo, na medida em que reforça o caráter regressivo do sistema tributário e não se coaduna com os objetivos expressos no texto constitucional de construção de uma sociedade justa, extinção da pobreza, promoção do desenvolvimento nacional e redução das desigualdades. Isso vale, por exemplo, para os casos de benefícios fiscais concedidos pelo governo federal a pessoas com grande capacidade contributiva. Por benefícios fiscais entende-se aqui as exonerações tributárias, que são as isenções, as reduções de tributo e a remissão (BREYNER, 2016, p. 158 apud MOURA; RIBEIRO, 2017, p. 232).
\end{abstract}

A opção política pela manutenção de uma tributação regressiva obsta as possibilidades do Poder Público aumentar efetivamente suas receitas para fazer frente às prestações positivas materiais exigidas pelos direitos fundamentais. Isso porque esse modelo tem como base contributiva a renda da população menos favorecida ${ }^{70}$. Desse modo, esgota-se mais facilmente a possibilidade de geração de receitas para o financiamento, pelo Estado brasileiro, de serviços públicos de forma universal e adequada. Tal quadro se torna mais preocupante quando se constata que as isenções e renúncias fiscais concedidas pela União, por exemplo,

em compasso com a capacidade de pagamento, exceto no caso das alíquotas seletivas (função da essencialidade do produto)" (MOURA; RIBEIRO, 2017, p. 231).

${ }^{70}$ Celia Lessa Kerstenetzk e Pedro Fandiño advertem para o paradoxo da Constituição de 1988: firmar bases de um Estado Social sem a correspondente solidariedade fiscal. Nas palavras dos pesquisadores: "Enquanto em muitos países desenvolvidos a progressividade do sistema tributário esteve presente nas bases da construção de Estados do bem-estar social (Gobetti \& Orair, 2016), no Brasil observamos uma importante inflexão regressiva da arrecadação, promovida justamente pela Constituição de 1988, a mesma que nos aproximou do desenho de um Estado do bem-estar social universalista” (KERSTENETZK; FANDIÑO, 2019, p. 323). Nesse cenário, os pesquisadores concluem que "O processo de desconstrução das medidas de equidade sugere implícito pacto social, a hipótese política mencionada ao início: as forças conservadoras que dominaram a transição democrática e se fizeram representar intensamente no processo constituinte consentiram a expansão dos direitos fundamentais sociais, desde que não tivessem que arcar com a necessária elevação de recursos, no que se empenharam eficazmente" (Ibid., 2019, p. 324). 
atingem justamente os impostos que têm as receitas repartidas com Estados e Municípios, como o imposto sobre produtos industrializados (IPI) e sobre a renda (IR), diminuindo também o montante das transferências relativas à cota de participação desses entes na distribuição federativa dos recursos.

Todavia, a despeito da estruturação pouco eficiente do modelo arrecadatório, o Estado também pode contar com outras fontes de receita: aquelas provenientes de empresas públicas e sociedades de economia mista e demais empresas controladas pelo Estado, consideradas receitas originárias, pois decorrentes da exploração do próprio patrimônio, pelo exercício de atividades econômicas ou pela realização de operações financeiras (FERNANDES; SILVEIRA, 2016, p. 21). A opção por um modelo de Estado mínimo, com a privatização de estatais lucrativas, diminui as possibilidades do Estado de auferir esse tipo de receita para complementar os déficits de arrecadação.

A insuficiência do montante de receitas provenientes da arrecadação e das receitas originárias para custear os gastos públicos pode gerar um déficit orçamentário. Mesmo quando esse déficit também não puder ser coberto por superávits produzidos em outros exercícios financeiros, o Estado ainda possui outros meios para fazer frente às despesas públicas.

Assim, um terceiro instrumento de que o Estado pode-se valer para auferir recursos financeiros e custear as despesas não cobertas é o financiamento público junto a terceiros: pela emissão de títulos da dívida pública ou pelo financiamento direto junto às instituições financeiras. A Constituição autoriza expressamente que o Estado possa-se valer de fontes de financiamento, apresentando parâmetros ao endividamento estatal. "A dívida constitui uma das fontes de recursos fundamentais ao setor público, especialmente quando destinada para promover o desenvolvimento econômico" (DINIZ; LIMA, 2016, p. 338).

Essa opção do constituinte torna questionável a vinculação do princípio da reserva do possível à ideia de proteção do equilíbrio orçamentário no sentido clássico: igualmente entre despesas e receitas públicas. Embora Ricardo Lobo Torres (2000, p. 286) defenda que a Constituição fez uma opção pelo equilíbrio econômico, o autor afirma que, quanto ao equilíbrio orçamentário, previsto na legislação ordinária, "não lhe pretendeu atribuir eficácia vinculante, pois permitiu o endividamento, ainda que limitado".

Um primeiro problema que se destaca em se relacionar o princípio da reserva do possível ao equilíbrio orçamentário é que a Constituição Federal de 1988 não reproduziu os 
dispositivos presentes na Constituição anterior sobre a exigência do equilíbrio orçamentário. ${ }^{71}$

Diferentemente do Brasil, a Alemanha possui em sua Constituição Federal normas explícitas que tratam do equilíbrio econômico e determinam, dentre outras exigências, que o plano orçamentário deve ser equilibrado nas receitas e nas despesas (TORRES, 2000, p. 279), o que justifica a consideração pelo Tribunal Constitucional Federal alemão da necessidade de observância dessa norma constitucional na decisão paradigma do numerus clausus I. Contudo, mesmo com expressa disposição constitucional que determina o equilíbrio entre receitas e despesas, a Alemanha apresenta atualmente uma dívida pública em torno de 59,8\% do $\mathrm{PIB}^{72}$, patamar esse que não pode ser considerado irrelevante.

Outro problema que pode ser levantado é que a consideração da exigência de equilíbrio fiscal/orçamentário como parâmetro do princípio da reserva do possível implicaria afirmar que prestações materiais constitucionalmente exigidas não seriam razoáveis porque há um desequilíbrio entre receita e despesa no atual exercício, ainda que haja recursos potencialmente disponíveis ou com expectativa de serem auferidos em exercícios futuros. E considerando que a receita orçamentária é estimada, qualquer equívoco técnico no dimensionamento dessa receita por ocasião da elaboração da lei orçamentária - que a estabeleça em patamar inferior à despesa fixada para o mesmo exercício orçamentário também teria o condão de condicionar o atendimento às prestações materiais, porque tecnicamente haveria déficit. Essa posição ofende o princípio da máxima utilização dos recursos nos moldes já explicitados. A razoabilidade da pretensão à prestação material concretizadora de um direito fundamental não deve ser aferida, tendo como principal orientação a busca do equilíbrio orçamentário em determinado período, mas a quantidade de recursos potencial e efetivamente disponível ao Poder Público para concretizá-la.

Ademais, como anteriormente asseverado, não se pode aferir a razoabilidade da pretensão do particular baseada em limitações impostas por alocações orçamentárias

71 A Constituição de 1967 foi a primeira que registra em nível constitucional a exigência expressa de observância do equilíbrio orçamentário, a exemplo do art. 66, caput, que determinava: "Art 66 - o montante da despesa autorizada em cada exercício financeiro não poderá ser superior ao total das receitas estimadas para o mesmo período" e no $\S 3^{\circ}$ do mesmo artigo, que dispunha-" Se no curso do exercício financeiro a execução orçamentária demonstrar a probabilidade de deficit superior a dez por cento do total da receita estimada, o Poder Executivo deverá propor ao Poder Legislativo as medidas necessárias para restabelecer o equilíbrio orçamentário" (BRASIL, 1967). Esses dispositivos não foram repetidos pela Emenda Constitucional $n^{\circ} 1 / 69$ e também pelo texto da Constituição Federal de 1988. Ressalta-se que mesmo na Constituição de 1969 havia exceções à disposição constitucional de equilíbrio no parágrafo $1^{\circ}$ do artigo 66 (BRASIL, 1967), como por exemplo, a exclusão desse cálculo da despesa referente a créditos extraordinários.

72 Fonte: Trading Economics. Disponível em $<$ https://pt.tradingeconomics.com/country-list/government-debt-togdp $>$. Acesso em 25.10.20 
irrazoáveis. A razoabilidade na aplicação dos recursos públicos escassos não pode ser diretamente condicionada pela exigência de equilíbrio fiscal, porque a exigência de equilíbrio fiscal se refere somente a aspectos quantitativos da receita e da despesa e não se preocupa com os aspectos qualitativos das alocações orçamentárias, dos quais o juízo de razoabilidade não deve se afastar. Assim, é possível que os agentes públicos possam determinar alocações de recursos de forma desarrazoada, não priorizando a efetivação dos direitos fundamentais e destinando montantes de recursos proporcionalmente maiores para o custeio de despesas não prioritárias ou supérfluas, ao mesmo tempo em que mantêm contabilmente as despesas públicas igualadas com as receitas públicas (ou seja, o equilíbrio fiscal estar sendo observado).

A existência de desequilíbrio orçamentário ou fiscal implica que, para cobrir suas despesas, o Estado tenha que lançar mão de outras fontes de receitas de natureza não tributária, o que pode implicar aumento da dívida pública. Ressalte-se que não há consenso científico sobre o que seria um limite ideal de endividamento público, o que fica então à mercê de interpretações das mais diversas ordens. Os parâmetros de dívida pública são estabelecidos, geralmente, por organismos internacionais (e.g. OCDE, FMI e Banco Mundial), que visam alcançar objetivos próprios, sem a consideração do sistema jurídico constitucional dos países em que esses parâmetros são adotados, por imposição dessas instituições, para a concessão de recursos e financiamentos.

Outro ponto é que a questão do endividamento público deve ser tratada não somente em termos quantitativos, mas também qualitativos. Isso porque, no âmbito do endividamento, o que ocorre é uma antecipação da receita que será utilizada para a geração de serviços públicos, os quais serão gozados também pelas gerações futuras e, por estas, pagos, ocorrendo uma troca intergeracional. Por tal razão, Scaff $(2018$, p. 298) adverte que o texto constitucional veda que haja endividamento para a realização de despesas ou gastos correntes, mas não para a realização de investimentos públicos (BRASIL, 1988, art. 167, inc. III), uma vez que estes permitem que seus utentes tenham efetiva fruição dos serviços e bens por esses recursos custeados, da forma mais perene possível.

Isso não significa que a capacidade de endividamento estatal não possa ser considerada numa análise global ${ }^{73}$ das possibilidades estatais de gasto público, mas não como

\footnotetext{
${ }^{73}$ Isso porque "o limite ao financeiramente possível precisa considerar ainda a capacidade de endividamento do Estado, um recurso também limitado pela capacidade contributiva de sua população atual e futura" (MARINO, 2015, p. 273).
} 
premissa necessária do princípio da reserva do possível. Isso porque adotar essa posição poderia obstar avanços significativos no nível de concretização dos direitos fundamentais enquanto houvesse qualquer nível de déficit fiscal ${ }^{74}$, ou seja, enquanto houvesse dívida pública a ser paga, pois os juros da dívida passaram a integrar o somatório das despesas primárias.

O quarto instrumento de que o Estado dispõe para suprir suas despesas é a emissão de moeda. Essa emissão possibilita aumentar a quantidade de dinheiro em circulação. Não significa necessariamente a impressão de cédulas ou cunhagem de moeda metálica, que normalmente já é feita pela Casa da Moeda, mas também pode se dar mediante a efetivação de operações de crédito (compra de títulos) por meio do Banco Central e de outras instituições financeiras. Ao adquirir títulos de instituições financeiras, o Estado entrega recursos financeiros a essas instituições, que podem repassar mediante financiamentos e linhas de crédito a empresas e indivíduo, estimulando novos investimentos produtivos e o consumo.

A corrente do pensamento econômico atualmente dominante tem baseado suas análises nas premissas relacionadas à Teoria Quantitativa da Moeda. Mendonça (2011), inicialmente formulada por David Hume, no século XVIII, em dois de seus ensaios: Of Money e Of Interest, de 1752. Para essa teoria, os níveis de preço e de inflação têm relação com a oferta de moeda em uma economia. Para seus adeptos, a quantidade de moeda disponível determinaria diretamente o nível dos preços em uma economia. Se a quantidade de moeda em circulação for maior do que a capacidade produtiva de oferta de bens e serviços pode ocorrer o que se costuma denominar de inflação de demanda. Portanto, o aumento da quantidade de moeda determinaria diretamente a taxa de inflação. Essa seria a restrição invocada pelos economistas adeptos dessas premissas para o controle da emissão de moeda pelos Estados. Portanto, a quantidade de moeda emitida por um Estado seria limitada pela capacidade produtiva de um país, ou seja, pela quantidade de bens e serviços produzidos.

Essa teoria, embora com raízes no século anterior, é abraçada pela corrente econômica denominada de neoliberalismo, que nasce no final da II Guerra Mundial, a partir da obra de Frederich Hayeck intitulada $O$ caminho da servidão (1944). A partir dessa obra, começa a se difundir uma proposta de Estado que diverge diametralmente do Estado de Bem-Estar ou

\footnotetext{
${ }^{74}$ Bercovici chama a atenção para o fato de que, a partir da década de 1980, a retórica do controle do déficit público, vinculada ao discurso neoliberal de repúdio ao Estado, é acompanhada pelo aumento dos gastos públicos, não em razão da implementação dos direitos fundamentais, "mas graças às despesas com a política monetária, especialmente as altas taxas de juros. O déficit público defendido por autores como John Maynard Keynes e Michal Kalecki era o déficit público do pleno emprego. Hoje é o déficit público que garante a remuneração para o capital" (BERCOVICI; MASSONETTO, 2006, p. 55).
} 
Estado Social. Para os adeptos dessa corrente, o igualitarismo preconizado pelo modelo de bem-estar destrói a liberdade dos cidadãos ao afetar a vitalidade da concorrência, sendo que para essa corrente de pensamento econômico a desigualdade é um "fator positivo". Segundo Ferrari (2001, p. 164), essa corrente considera necessário manter um Estado "forte em sua capacidade de romper o poder dos sindicatos e no controle do dinheiro, mas parco em todos os gastos sociais e nas intervenções econômicas".

A ênfase está na estabilidade monetária como meta suprema de todo governo, nos moldes da Teoria Quantitativa da Moeda. Com base em suas premissas, para manter esse equilíbrio monetário, seria necessária "uma disciplina orçamentária, com a contenção dos gastos com bem-estar. Paralelamente, se propagava a restauração da taxa 'natural' de desemprego", criando uma reserva de desempregados para enfraquecer os sindicatos (FERRARI, 2001, p. 164). Além disso, o neoliberalismo apregoa serem necessárias "reformas fiscais para incentivar os agentes econômicos, o que se traduz por isenções e reduções de impostos sobre os rendimentos mais altos e sobre as vendas" (FERRARI, 2001, p. 164).

Modernamente, economistas que se dedicam ao estudo da Teoria Moderna da Moeda ${ }^{75}$ (Neo-Cartalismo ou Modern Money Theory, MMT) estão revendo suas premissas, que se amoldam ao modelo neoliberal acima descrito, o qual já tem seus fundamentos questionados. Principalmente após a crise de 2008, os pilares do modelo neoliberal e da Teoria Quantitativa da Moeda se demonstraram incapazes de reanimar a dinâmica das economias capitalistas que apresenta crises cíclicas ${ }^{76}$. A principal contribuição desta teoria para o tema do princípio da reserva do possível é que ela, ao questionar os tradicionais dogmas da Teoria Quantitativa, demonstra que os Estados que têm o poder de emitir sua moeda não estão sujeitos às mesmas restrições financeiras que os demais agentes na economia e, portanto, amplia o que se pode

${ }^{75}$ A Teoria Moderna da Moeda (ou Neo-Cartalismo ou de Modern Money Theory, MMT) foi incialmente proposta por Warren Mosler. Seu desenvolvimento conceitual "foi levado adiante por professores da Universidade de Missouri-Kansas, como L. Randall Wray e Stephanie Kelton. O livro de Wray, Modern Money Theory (2015), é a mais completa exposição dos princípios da MMT e de porque a má compreensão da moeda leva a uma série de equívocos na formulação de políticas macroeconômicas. Understanding Government Finance (2016), de Brian Romanchuk, é uma versão sintética, dirigida ao público não especializado, das razões pelas quais estados que têm o poder de emitir sua moeda não estão sujeitos às mesmas restrições financeiras que os demais agentes na economia” (RESENDE, 2019, p. 3).

76 Pedro Paulo Z. Bastos (2020, p. 3) esclarece que o "debate internacional sobre a emissão de moedas pelos países com soberania monetária inicia-se depois da crise financeira global de 2008-9, quando vários economistas rediscutiram a proposta feita para combater a depressão japonesa pelo presidente do Federal Reserve. Ben Bernanke, quando ainda era professor de Princeton em 1999 defendeu a emissão de moeda para financiar transferências para os cidadãos japoneses, não necessariamente através de um corte de impostos (Bernanke 1999, p. 21-22). Assim, Bernanke conferia conteúdo prático à metáfora do 'dinheiro de helicóptero', sugerida por Milton Friedman (1969, p. 4-5) ao cogitar sobre a transferência direta de dinheiro emitido pelo banco central para os cidadãos". 
entender como fático e economicamente possível a esses Estados.

Na Nota Técnica $n^{0}$ 15, do Centro de Estudos de Conjuntura e Política Econômica, da UNICAMP, o economista Pedro Paulo Zahluth Bastos (2020, p. 3-7), elenca vários argumentos favoráveis à utilização do mecanismo de emissão de moeda. Um deles consiste no fato de que o papel-moeda teria um custo fiscal desprezível se comparado com os encargos da dívida pública que contribuíram para o aumento do déficit primário a partir de 2016. Ressaltase que os juros e encargos da dívida pública compõem as despesas primárias e não sofreram limitações pela Emenda Constitucional n n 95/2016.

Um dos principais argumentos que os economistas ortodoxos opõem à emissão de moeda é o risco de aumento da inflação. Contudo, esse argumento tem sido desmistificado. Bastos (2020, p. 3) esclarece que, no atual contexto de recessão e pandemia da COVID-19, caso o aumento da moeda em circulação estimulasse o consumo dos cidadãos (por exemplo, mediante a distribuição do denominado auxílio emergencial) a ponto de gerar inclusive alguma inflação, a emissão monetária teria um efeito positivo, na medida em que permitiria superar a recessão, promovendo crescimento da economia. A consequência seria a elevação da arrecadação fiscal, em virtude do aumento do consumo dos cidadãos e do lucro das empresas. Assim, nem todo o déficit público necessariamente tem que se transformar em dívida pública quando se trabalha com a hipótese de emissão de moeda ${ }^{77}$.

Da mesma forma que a obra de Holmes e Sunstein trouxe um novo olhar sobre a diferenciação entre os direitos fundamentais individuais e os sociais no que tange ao seu custo à sociedade, a Teoria Moderna da Moeda pode significar uma nova concepção para abordagem dos efetivos limites estatais para implementar os direitos fundamentais, refletindo também no tratamento das premissas fáticas do princípio da reserva do possível. Os adeptos da Teoria Monetária Moderna têm defendido que um Estado que possui soberania monetária pode exercê-la dentro de certas condições, sem que isso implique aumento da inflação, ao contrário do que afirmava a Teoria Quantitativa da Moeda. Assim, a emissão de moeda seria uma opção viável e alternativa ao endividamento público junto às instituições financeiras ${ }^{78}$.

77 Bastos explica o impacto positivo na economia "Ao aumentar a renda dos cidadãos, a transferência governamental tende a estimular a demanda agregada, a arrecadação de impostos e os preços, além de desconcentrara distribuição de renda. O impacto favorável sobre o PIB e a relação dívida pública/PIB tende a ser tanto maior quanto menor a renda prévia dos cidadãos que receberem a transferência governamental (tendo maior a propensão a consumir), e quanto maior a tendência em usar papel-moeda ao invés de reservas bancárias" (BASTOS, 2020, p. 3).

78 Essa afirmação é corroborada pelo renomado economista André Lara Resende, que esclarece: "Como ao gastar o governo "emite" reservas bancárias, não é preciso que obtenha os recursos para gastar, nem através de impostos, nem através de qualquer fonte alternativa de financiamento. [...] Mais direto impossível: o 
Portanto, nem todo aumento no gasto público implica necessariamente aumento de tributos ou da dívida pública, principalmente se o gasto público estimular o crescimento econômico ${ }^{79}$. $\mathrm{O}$ economista André Lara Resende afirma a importância do gasto público para o desenvolvimento da economia:

Ao contrário do que se convencionou acreditar, o governo não tributa para obter dinheiro para gastar, pois quando gasta, sempre, cria dinheiro, ou dito de outra forma, credita as reservas bancárias das suas contrapartes. Do ponto de vista microeconômico, também a forma como o governo tributa, tem impactos redistributivos e alocativos importantes na economia (RESENDE, 2019, p. 9).

Contudo, Resende (2019, p. 10) adverte que existem premissas limitadoras da possibilidade de o Estado emitir sua própria moeda para custear suas despesas. A primeira, seria a possibilidade do acréscimo nos gastos do governo aumentar a demanda por produtos e serviços e pressionar a capacidade instalada das empresas que os fornecem, provocando o aumento dos preços e, consequentemente, inflação. Essa hipótese não se aplicaria aos países onde há capacidade ociosa tanto em relação à capacidade instalada da indústria, como em relação à mão de obra. A segunda hipótese se daria quando o Estado possuir dívida em moeda estrangeira. Como não é possível emitir moeda estrangeira, a dívida externa apresentaria o risco de não poder ser refinanciada, pois o governo neste caso sempre teria que adquirir moeda estrangeira para promover o pagamento de seus títulos. E poderia ocorrer de que nem sempre a moeda estrangeira fosse ofertada em quantidade suficiente no mercado, desvalorizando a moeda nacional. Um governo só não estaria sujeito à restrição financeira nos seus gastos quando estes são realizados em moeda nacional, pois neste caso não depende de adquirir moeda estrangeira no mercado para liquidar suas dívidas. $\mathrm{O}$ autor esclarece que a Grécia, assim como todos os países que adotaram o euro, abdicaram do poder de emitir a moeda nacional, o que transforma a dívida interna no equivalente a uma dívida externa fixada em moeda estrangeira (RESENDE, 2019, p. 10). Ou seja, a dívida desses países que era fixada na moeda nacional é transformada em euro.

banco central, o governo, não precisa de impostos para financiar seus gastos; basta creditar as reservas bancárias das suas contrapartes (RESENDE, 2019, p. 9).

79 Nesse sentido esclarece-se que "o argumento keynesiano segundo o qual os gastos do governo teriam a propriedade de provocarem crescimento econômico se aplica a situações de forte ociosidade do sistema produtivo, quando a economia ameaça entrar em colapso e a incerteza cresce a ponto de paralisar não apenas as decisões de investir, mas também a própria produção. Para se sair de uma depressão (1929-1933), ou quando se está à beira de uma (2008-2009), é justificável a realização de expressivos déficits orçamentários. Assim, em momentos de crises é que o gasto público tem sua importância de forma a possibilitar a injeção de recursos na economia" (MARINO, 2015, p. 177). 
O economista esclarece que embora o governo brasileiro não esteja sujeito a uma restrição financeira a preocupação dos formuladores de políticas não deve estar somente no financiamento das despesas públicas, mas sim na qualidade dessas despesas, pois a combinação dos gastos e das receitas tributárias é da mais alta importância para o bom funcionamento da economia (RESENDE, 2019, p. 10), consoante já asseverado.

É cediço que o Brasil possui soberania monetária para emitir sua própria moeda. Ademais, apresenta um parque industrial, com cerca de $66 \%$ de sua capacidade ociosa ${ }^{80}$ e um grande contingente de desempregados - elementos que indicam estar longe da situação de pleno emprego dos meios de produção. Atualmente, o país também não possui dívida em moeda estrangeira - ao contrário, possui um estoque considerável de reservas cambiais. Desse modo, não haveria restrições econômicas para que os gastos públicos pudessem ser custeados pela emissão de moedas. Assim, a opção pelo endividamento e por medidas de austeridade fiscal é política e não economicamente necessária. As limitações fiscais são autoimpostas e não decorrência necessária de fatores econômicos, a exemplo das restrições trazidas pela Lei de Responsabilidade Fiscal e da EC n ${ }^{\circ}$ 95/2016.

A Teoria Monetária Moderna - cujos pressupostos se mostraram mais próximos da realidade do que as teorias clássicas e neoliberais, principalmente após a crise de $2008^{81}$ coloca em xeque a afirmação de que os gastos governamentais implicam necessariamente um maior ônus aos contribuintes ${ }^{82}$ e que, ao atender uma pretensão individual, o Estado tem que abdicar, necessariamente, de atender a outras pretensões igualmente relevantes. Esse pressuposto decorre da teoria clássica da dívida e apoia a ideia de "equilíbrio orçamentário em que o financiamento por tributação é fonte necessária para os gastos correntes" (DINIZ;

\footnotetext{
${ }^{80}$ Segundo a pesquisa de Sondagem Industrial divulgada em 22 de maio de 2019, pela Confederação Nacional da Indústria $(\mathrm{CNI})$, desde janeiro daquele ano, o setor opera, em média, com $66 \%$ da utilização da capacidade instalada. $\mathrm{O}$ documento relatou que "O nível de atividade permanece baixo, com elevada ociosidade do parque produtivo e a indústria está trabalhando com estoques indesejados pelo terceiro mês consecutivo". Disponível em:https://www.em.com.br/app/noticia/economia/2019/05/22/internas_economia,1055743/cni-ociosidadeindustrial-continua-alta-com-uso-de-66-da-capacidade.shtml. Acesso em: 27 dez. 2019.

${ }^{81}$ Edilberto Carlos Pontes Lima afirma que "sem a ação dos governos, a economia teria entrado em colapso. Grandes bancos privados foram estatizados nos Estados Unidos, a regulação bancária tornou-se mais restritiva, amplos pacotes de apoio foram providenciados aos países em situação mais crítica como Portugal, Espanha e Grécia, reafirmando não apenas de instituições nacionais, mas de organismos supranacionais para assegurar a estabilidade. A crise - revelou mais uma vez - as fragilidades do liberalismo econômico [...] Tornou-se evidente que apenas mecanismos clássicos de intervenção estatal não são suficientes" (LIMA, 2015, p. 9).

82 Verifica-se que Robert Alexy também se vale dessa premissa para argumentar sobre as colisões de direitos fundamentais sociais, como se verifica do trecho a seguir: "Todos os direitos fundamentais sociais são extremamente custosos. Para a realização dos direitos fundamentais sociais o Estado pode apenas distribuir aquilo que recebe de outros, por exemplo na forma de impostos e taxas. Mas isso significa que os freqüentemente suscitados limites da capacidade de realização do Estado não decorrem apenas dos bens distribuíveis existentes, mas sobretudo daquilo que o Estado, para fins distributivos, pode tomar dos proprietários desses bens sem violar seus direitos fundamentais" (ALEXY, 2015, p. 510 - itálico nosso).
} 
LIMA, 2016, p. 340). Contudo, verifica-se que, jurídica e economicamente, essa premissa não é necessária - apesar de ser tratada como um "dogma financeiro", cujos fundamentos geralmente não são empiricamente comprovados. É postura estatal determinada por uma opção política e de autoimposições legislativas de não se valer dos demais instrumentos de geração de receitas menos onerosos para o Estado e para o cidadão e priorizar o endividamento junto ao setor financeiro privado ${ }^{83}$.

No entanto, os Estados e Municípios, que não dispõem de soberania monetária, dependem, para o custeio das despesas públicas, primordialmente dos recursos provenientes das transferências da União, que detém a maior parcela de tributos arrecadados (principalmente mediante contribuições). À União cabe promover sua repartição de forma a garantir a sustentabilidade financeira de todos os entes federados, suprindo as desigualdades regionais, proporcionalmente aos seus encargos na realização dos direitos fundamentais. Esse objetivo, muitas vezes, na prática, não tem se concretizado, o que agrava o problema da escassez de recursos nesses entes federados. No caso de prestações exigidas em face dos Estados e dos Municípios, a correta ponderação do princípio da reserva do possível, com base em premissas confiáveis, torna-se mais relevante tanto para evitar a concessão de prestações irrazoáveis, quanto para se evitar o indeferimento de prestações constitucionalmente devidas.

Com acerto, Barcellos adverte que

embora a ideia da escassez de recursos possa parecer verdadeiramente assustadora, é preciso recolocá-la em seus devidos termos. Isso porque, em primeiro lugar, afora países em que os níveis de pobreza da população sejam extremos, faltando mesmo capacidade contributiva, os Estados têm, em geral, uma capacidade de crédito bastante elástica, tendo em vista a possibilidade de aumento de receita. Em um curto espaço de tempo, pouco mais de um ano no caso brasileiro, a autoridade pública tem condições técnicas de incrementar suas receitas, com a majoração de tributos, por exemplo (BARCELLOS, 2011, p. 281-282).

No mesmo sentido, Marino afirma:

Outra razão para se colocar a limitação de recursos em perspectiva é o fato de que, ainda que falte capacidade contributiva no presente, os Estados possuem uma

\footnotetext{
${ }^{83}$ Pedro Paulo Zahluth Bastos afirma que: "A preferência política dos credores da dívida pública virou tabu inscrito no Artigo $164 \S 1^{\circ}$ da Constituição Federal, que proíbe o Banco Central de financiar diretamente o gasto público através da compra de emissões primárias de títulos públicos. Os credores, sobretudo aqueles da parcela mais rica entre os brasileiros, preferem que o governo gaste se endividando com eles com a taxa de juros mais alta possível, proibindo a emissão. Ao mesmo tempo, vetam politicamente impostos progressivos. Quando a dívida pública aumenta, a pressão política dos credores se exerce sempre para que o governo corte gastos para mitigar seu próprio medo de calote" (BASTOS, 2020, p. 10).
} 
capacidade de crédito bastante elástica, tendo em vista a possibilidade de aumento de receitas no futuro via elevação de tributos. Sob esse prisma, o "possível" não seria objetivamente aferível, pois o Estado poderia possibilitar sua atuação não só pela reorganização das prioridades orçamentárias e pela racionalização das despesas, mas também pela contração de novos empréstimos, criação de novos tributos ou majoração de alíquotas e redução da sonegação (MARINO, 2015, p. 173).

Extrai-se dessas assertivas que assiste razão à doutrina que afirma que o déficit de concretização dos direitos fundamentais sociais na realidade brasileira seria muito mais determinado por escolhas políticas alocativas feitas pelos governantes que determinam a distribuição de renda no país e a oferta de serviços públicos, do que pela escassez fática de recursos. Esse o fato pode ser aferido ao se verificar que, segundo a classificação de outubro de 2020, elaborada pelo Fundo Monetário Internacional (FMI) ${ }^{84}$, o Brasil ocupava a posição de $11^{\circ}$ em termos de Produto Interno Bruto (que mede a riqueza produzida em um país em determinado ano). Por sua vez, em relação ao Índice de Desenvolvimento Humano (IDH), o Brasil foi arrolado na $84^{\mathrm{a}}$ posição no Human Development Report 2020, elaborado pela Organização das Nações Unidas $(\mathrm{ONU})^{85}$. Da disparidade entre o potencial econômico do Estado brasileiro em gerar riquezas e o déficit de concretização dos direitos fundamentais infere-se que ao argumento do atingimento de um esgotamento econômico ou de uma escassez fática, que passível de limitar a oferta de prestações materiais estatais fundamentais , devem ser considerados com maior cautela, uma vez que, na maioria das vezes, carece comprovação empírica ${ }^{86}$.

Destarte, são diversas as possibilidades a que o Estado brasileiro pode recorrer visando à obtenção de recursos públicos para fazer frente ao custeio dos serviços públicos. Desse modo, a determinação do que é faticamente possível no Brasil é, pois, extremamente elástica e dificilmente seria aferível de forma objetiva, pois o que é faticamente possível depende da teoria econômica subjacente à análise dos conceitos jurídico-financeiros apropriados para aferir se a exaustão orçamentária realmente se deu, e se o Estado efetivamente esgotou as possibilidades de se valer de todos os instrumentos que lhe são disponíveis.

84 Fonte: World Economic Outlook Database. International Monetary Fund. Disponível em: $<$ https://www.imf.org/en/Publications/WEO/weo-database/2020/October>. Acesso em: 30 mar. 2021.

${ }^{85}$ Vide relatório completo. Disponível em $<\mathrm{http} / / \mathrm{hdr}$.undp.org/sites/default/files/hdr2020.pdf $>$. Acesso em: 30.03.2021. O IDH possibilita uma avaliação do desenvolvimento de um país não somente a partir do foco dos avanços econômicos, mas também a partir da avaliação dos avanços no bem-estar humano.

86 Nesse sentido, há certa razão na crítica formulada por José Afonso da Silva, em relação à reserva do possível, no sentido de que "seria uma teoria dogmática do neoliberalismo que dá muita munição aos adeptos dessa corrente ideológica e conservadores em geral contra a realização dos direitos fundamentais sociais" (SCAFF, 2018, p. 297). 
Defende-se que quando o Estado opta por políticas tributárias, econômicas e monetárias que não promovem adequadamente a distribuição do excedente econômico de forma que cada pessoa, por si mesma, obtenha no mercado bens e serviços suficientes para a satisfação de necessidades e interesses visando à concretização de sua dimensão de dignidade humana, esse Estado atrai para si o dever de oferecer prestações materiais e normativas para o suprimento da desigualdade distributiva gerada. Essa tarefa é realizada na medida em que as prestações relativas aos direitos fundamentais sociais forem adequadamente implementadas e garantidas a quem delas necessitar, cabendo aos agentes públicos se valerem de todos os instrumentos constitucionais e economicamente disponíveis para auferir os recursos necessários à oferta das prestações constitucionalmente devidas.

Dessa análise, pode-se inferir que a limitação de recursos causada pela dimensão fática da escassez é hipótese melhor aferível nos diversos países que sofrem as restrições acima expostas, como os países integrantes da União Europeia, que abriram mão da sua soberania monetária. Ressalta-se que o argumento empírico, como a escassez de recursos públicos, obriga o jurista aproximar-se da realidade e compreender, ainda que minimamente, a dinâmica de outras áreas do conhecimento científico. A correta compreensão da natureza e das dimensões fáticas e jurídicas que envolvem o princípio da reserva do possível pode evitar o seu tratamento, por vezes, retórico nas ações em que é trazido como argumento para obstar a efetivação de uma prestação material requerida pelo particular ao Estado. Nesse sentido, Sarlet ressalta que

[...] é certo que as limitações vinculadas à reserva do possível não são em si mesmas uma falácia - o que de fato é falaciosa é a forma pela qual o argumento tem sido por vezes utilizado entre nós, como óbice à intervenção judicial e desculpa genérica para uma eventual omissão estatal no campo da efetivação dos direitos fundamentais, especialmente daqueles de cunho social (SARLET, 2017a, p. 614).

Uma ressalva merece ser feita: tanto a Economia quanto o Direito são ciência sociais aplicadas, cujos conceitos e regras são culturalmente formulados e não realidades dadas. Assim, sendo os conceitos, uma produção cultural não deve ser tratada como fato da natureza ou fato necessário, incluindo o conceito de mercado, inflação ou de escassez. Percebe-se que, quando se trata da ponderação do princípio da reserva do possível, considerando sua dimensão fática, as premissas emprestadas da teoria econômica para fundamentar a análise jurídica do instituto não são devidamente aclaradas nas decisões judiciais e nem pela doutrina. 
E, a depender da teoria econômica adotada, as conclusões jurídicas podem-se apresentar em sentidos diversos, pois podem partir de premissas formuladas a partir de realidades sociais que guardam grande distância temporal da realidade em que será aplicada.

A crise financeira mundial que eclodiu em 2008, bem como a atual crise sanitária provocada pela pandemia COVID-19, tornaram evidente a importância do Estado para a estabilização da economia e para a garantia dos direitos fundamentais, demandando a revisão dos "dogmas" econômicos de vertente ortodoxa, como já começa a ser feito na própria teoria econômica com as análises da Moderna Teoria da Moeda. Na medida em que esses dogmas são questionados, outras possibilidades científicas começam a ser propostas, permitindo o avanço do conhecimento.

Portanto, o pesquisador deve evitar a naturalização dos conceitos econômicos que são transportados para o Direito, sem uma compreensão mínima das premissas que fundamentam suas análises. Isso porque, cada teoria econômica traz subjacente um determinado modelo de Estado, que, em alguns casos, pode não coadunar com o modelo inserido em cada Constituição. Ferrari (2001, p. 167), relembrando as lições de Migual Reale, afirma que a Constituição brasileira não consagrou um liberalismo contrário à justiça social. Ao contrário, a opção constitucional se deu em direção ao um balanceamento de valores diversos postos por conjunturas também diversificadas. Esse pensamento se assemelha com a posição defendida por Washington Albino Peluso de Souza sobre a ideologia constitucionalmente adotada ${ }^{87}$. Dessa forma, como em qualquer outro ramo da ciência, a naturalização das premissas de teorias econômicas sobre a teoria jurídica, especialmente, sobre a teoria dos direitos fundamentais, podem acarretar distorções em relação à análise jurídica da efetividade das normas constitucionais que asseguram esses direitos, pela sobreposição da dimensão econômica sobre a dimensão jurídica desses fenômenos. Quando essa sobreposição, ainda que de forma inconsciente, ocorre, o código lícito/ilícito ou justo/injusto passa a se submeter ao peso excessivo de razões pragmáticas/eficientistas que orientam o código do econômico.

A análise deste capítulo se propôs a demonstrar que há uma diversidade de instrumentos que possibilitam ao Estado auferir maior receita e que podem ser

87 Giovani Clark, Leonardo Alves Correa e Samuel Pontes Nascimento esclarecem que a "ideologia constitucionalmente adotada" é "um parâmetro hermenêutico segundo o qual o intérprete, ao analisar a juridicização da política econômica, deve condicionar-se aos fundamentos normativo-axiológicos positivados na Constituição Econômica. Inegavelmente deve-se admitir que a defesa de um parâmetro hermenêutico plural constitui um elemento estratégico contra as argumentações anarco-liberais que insistiam em promover uma interpretação 'mercadologicamente adequada' da Constituição Econômica" (CLARK; CORREA; NASCIMENTO, 2013, p. 269). 
compatibilizados com a realidade brasileira, mas não estão sendo utilizados. Essa constatação converge para as afirmações de Célia Lessa Kerstenetzk e Pedro Fandiño (2019, p. 325) sobre o modelo de tributação praticado no Brasil (já abordadas neste capítulo) e também de Olsen (2006, p. 191-192) no sentido de que, no Brasil, a "a escassez dos recursos econômicos destinados à realização destes direitos não é natural, essencial, mas artificial, fruto da escolha realizada pelos poderes públicos" 88 .

Disso decorre que a escassez de recursos públicos - quando alegada pelo Poder Público como obstáculo à efetivação de um direito fundamental pleiteado em juízo - não é algo que deve ser tratado como uma presunção legal (eis que não há norma jurídica que autorize tal presunção e somente as presunções legais podem ser juridicamente consideradas), ou como fato notório ou autoevidente, mas como fato alegado por uma das partes e que exige prova judicial de sua ocorrência e extensão de acordo com a lei processual vigente.

A seguir, adentrar-se-á na análise da dimensão jurídica da escassez, que, sob o ponto de vista da doutrina pesquisada, é resultado das escolhas alocativas orçamentárias e que neste trabalho também compõe a dimensão da premissa empírica do principio da reserva do possível.

\subsubsection{A dimensão jurídica da escassez de recursos: as escolhas alocativas orçamentárias}

Os direitos fundamentais a prestações fáticas vão demandar que o Estado estabeleça políticas públicas e direcione recursos públicos suficientes de forma a proporcionar meios materiais para a fruição dessas prestações por todos de que delas necessitarem. Contudo, a forma de sua satisfação não é predeterminada pela Constituição. Assim, abrem-se inúmeras possibilidades ao legislador e ao gestor de planejar e definir as prioridades de ação para levar a cabo essas prestações. Em um primeiro momento, definem-se a política pública a ser adotada e as metas a serem cumpridas, a exemplo do Plano Nacional de Educação (PNE) ${ }^{89}$.

88 No mesmo sentido Sgarbossa afirma que: "Ocorre que dificilmente se depara, na realidade concreta, com o caso-limite da escassez real ou econômica de tipo natural severo ou suave, por exemplo. Por outro lado, não se tem notícia, até o momento, de demandas em que se postula a outorga de prestações realizadoras dos direitos fundamentais sociais dependentes de bens cuja escassez seja econômica, real" (SGARBOSSA, 2010, p. 219).

89 Conforme o site do Ministério da Educação e Cultura, "o Plano Nacional de Educação para o decênio 2014/2024, instituído pela Lei $\mathrm{n}^{\circ}$ 13.005/2014 definiu 10 diretrizes que devem guiar a educação brasileira neste período e estabeleceu 20 metas a serem cumpridas na vigência. Essa mesma lei reitera o princípio de cooperação federativa da política educacional, já presente na Constituição Federal e na Lei de Diretrizes e Bases da Educação Nacional, ao estabelecer que "a União, os Estados, o Distrito Federal e os Municípios atuarão em regime de colaboração, visando ao alcance das metas e à implementação das estratégias objeto 
Num segundo momento, destinam-se recursos suficientes para efetivação das ações escolhidas.

Já foi analisado que, em relação aos recursos públicos, a escassez natural severa - na qual não há nada que se possa fazer para aumentar a oferta do bem - não é a regra, tendo em vista a diversidade de instrumentos que possibilitam ao Estado auferir maior receita e que podem ser compatibilizados com a realidade brasileira, mas não estão sendo utilizados por opções políticas do legislador e do administrador. Assim, a escassez que constitui premissa empírica da reserva do possível está muito mais relacionada ao tipo de escassez artificial, que se refere às hipóteses em que o governo pode, se assim decidir, tornar o bem acessível a todos a ponto da satisfação. Isso se verifica principalmente nos casos em que o recurso não está alocado em determinada rubrica orçamentária, mas há possibilidade de realocação da verba pública para o atendimento de um determinado direito fundamental, sem prejuízo a outros direitos fundamentais que igualmente demandam recursos públicos para a sua implementação. Nesses casos, não se pode falar em incidência do princípio da reserva do possível e sim de omissão estatal, por não se tratar de uma limitação orçamentária razoável, que constitui o pressuposto fático daquele princípio, como defendido.

Contudo, Sgarbossa (2010, p. 220) afirma que há situações em que os recursos materiais e financeiros podem ser faticamente existentes, muito embora sua "alocação em determinados setores acaba por implicar o não atendimento de outras necessidades, por uma decisão disjuntiva do órgão ou agente com competência em matéria alocativa". Assim, há situações em que um direito fundamental social pode colidir com outros direitos fundamentais e haverá a impossibilidade de remanejamento de verbas públicas sem o comprometimento de outros interesses relevantes ${ }^{90}$. Esse caso, sim, corresponde à premissa fática do princípio da reserva do possível, cuja alegação é, portanto, cabível.

Noutro giro, indaga-se se os governantes teriam discricionariedade ampla e irrestrita para decidir não tornar acessível a todos a satisfação um bem ou serviço que concretiza prestações de direitos fundamentais, mesmo havendo recursos à disposição do Estado, ou formas possíveis juridicamente de obtê-los. Ou seja, seria constitucionalmente permitido, por

deste Plano" e que "caberá aos gestores federais, estaduais, municipais e do Distrito Federal a adoção das medidas governamentais necessárias ao alcance das metas previstas neste PNE”. (Fonte: $<$ http://pne.mec.gov.br/>. Acesso em: 3 nov. 2020).

90 Scaff (2019, p. 297) afirma que a eleição de prioridades ocorre no âmbito orçamentário oriunda, como regra, da deliberação entre os poderes Executivo e Legislativo, não se refere propriamente à reserva do possível, mas ao conceito de escolhas públicas trágicas, que é eminentemente político. Segundo o autor, esse conceito refere-se às "opções políticas que são possíveis de serem realizadas com os recursos existentes". 
uma escolha pública, tornar indisponíveis os recursos públicos economicamente existentes e suficientes e destiná-los a outras finalidades, deixando de atender ou atendendo de forma insuficiente as demandas de prestações que efetivam os direitos fundamentais? É o que se pretende analisar.

3.1.2.1 As escolhas alocativas e a prioridade da proteção dos direitos fundamentais como ideia reguladora do sistema orçamentário

O princípio da reserva do possível exige a consideração de que: a) todos os direitos fundamentais gozam, em abstrato, de igual importância e devem ser realizados no maior grau possível; b) que a escassez dos recursos públicos constituir condição fática que impede a fruição simultânea e plena por todos os cidadãos de toda e qualquer prestação que a norma principiológica de direito fundamental assegura prima facie; c) que, por força de norma constitucional ${ }^{91}$ há proibição de se efetuarem gastos não previstos nas leis orçamentárias. $\mathrm{O}$ reconhecimento de que os recursos públicos são escassos exige a razoabilidade em sua aplicação, buscando os meios mais eficientes na consecução dos fins constitucionalmente estabelecidos.

Justamente por não serem ilimitados, Barcellos (2011, p. 284) defende que os recursos públicos disponíveis devem ser aplicados "prioritariamente no atendimento dos fins considerados essenciais pela Constituição até que eles sejam realizados. Os recursos remanescentes haverão de ser destinados de acordo com as opções políticas que a deliberação democrática apurar em cada momento". Dessa afirmação, extrai-se que a concretização dos direitos fundamentais é uma política de Estado e não uma política de governo. Por esse entendimento, garantir condições materiais essenciais à dignidade humana é prioridade imposta ao Estado brasileiro e deve, portanto, repercutir na forma de decisão sobre a aplicação dos recursos públicos.

Priorizar direitos fundamentais significa destinar recursos suficientes para determinada área, pois de nada adianta o estabelecimento de ações e metas se os recursos orçamentários e humanos não forem disponibilizados, o que implica despesas ao poder público ${ }^{92}$. O tema da

91 “Art. 167. São vedados: I - o início de programas ou projetos não incluídos na lei orçamentária anual” (BRASIL, 1988, CF).

92 Nesse sentido vale a afirmação de Osmir Antonio Globekner no sentido de que "implementar direitos implica alocar recursos, conquanto se reconheça também, como já exposto, que, no sentido contrário, alocar recursos significa selecionar quais direitos serão implementados" (GLOBEKNER, 2017, p. 138). 
definição dos gastos públicos de acordo com as prioridades constitucionais ganha maior relevo no contexto brasileiro atual, em que medidas de austeridade estão sendo constitucionalizadas, reduzindo a disponibilidade de recursos para implementação de direitos fundamentais. É o que se verifica desde a Emenda Constitucional n. 95/2016, que estipulou um teto para as despesas primárias pelo período de 20 anos, que tem o condão de inibir o avanço em qualidade e em conteúdo das prestações concretizadoras dos direitos fundamentais, ainda que haja demandas insatisfeitas e as receitas sejam suficientes para o custeio em maior extensão dos direitos.

As dificuldades para a efetivação satisfatória das prestações exigidas pelos direitos fundamentais podem ser agravadas quando se constatam decisões alocativas que promovem inversão das prioridades orçamentárias, com a realização de gastos menos relevantes ${ }^{93} \mathrm{em}$ detrimento das prestações de direitos fundamentais. Mendonça (2010, p. 161) chama a atenção para a coexistência de duas situações não raras - o custeio com verba pública de shows "gratuitos" na praia em contraposição à existência de hospitais em situação caótica -, o que evidenciaria uma incongruência, a exigir reflexão governamental e da sociedade. O autor não defende a inexistência de eventos culturais, mas que a destinação de verbas para essas atividades parece demonstrar que existe algum dinheiro passível de redistribuição. Outra situação é a concessão de isenções fiscais em período de calamidade pública ou o investimento em obras ou serviços menos prioritários, como obras de embelezamento urbano em detrimento de serviços públicos de saúde de saneamento básico (MENDONÇA, 2010, p. 174).

Élida Graziane Pinto (2019, p. 3) afirma que não há discricionariedade de realizar “despesas voluntariosas" quando ainda não estiverem cumpridas, por parte do Estado, as obrigações de fazer legais e constitucionais que amparam a eficácia de um direito fundamental $^{94}$. Tal situação geraria uma presunção relativa de irregularidade das despesas

93 Como exemplo dessa inversão de prioridades, Ana Paula Ávila e Daniella Bitencourt (2017, n.p.) chamam a atenção para o fato de que, em paralelo ao discurso que invoca a escassez de recursos públicos e a necessidade imperiosa de contenção de gastos, pode-se constatar a existência de "gastos antagônicos à exigência de austeridade fiscal, como, por exemplo, o gasto de 8 mil reais feito pelo governo Federal, em setembro de 2017, com apenas 7 caixas de bombons, cujas embalagens são folheadas a ouro, para presentear autoridades". Esse exemplo ilustra que nem sempre o problema da escassez está atrelado à inexistência ou insuficiência de recursos, mas à qualidade do gasto.

94 Élida Graziane Pinto aponta inúmeros atos discricionários de execução orçamentária presumidamente conflitantes com as prioridades constitucionais e legais que amparam especialmente os direitos fundamentais sociais à saúde e à educação e que, segundo ela, reclamam motivação circunstanciada. Dentre eles destacamse: "I - Realizar despesas com publicidade institucional dos atos, programas, obras, serviços e campanhas dos órgãos públicos municipais, ou das entidades da administração indireta, salvo em caso de grave e urgente 
discricionárias que constrangem a eficácia das normas de direito fundamental. Para a autora, em cada escolha estatal há um custo que deve ser analisado, bem como se deve verificar se essa escolha é constitucional e socialmente legítima à luz do ordenamento vigente.

Assevera-se que a discricionariedade atribuída aos órgãos estatais deve ser entendida como um espaço de liberdade para os órgãos agirem dentro do âmbito de suas competências na escolha dos meios lícitos, necessários e suficientes para o atingimento do fim comandado na norma constitucional ${ }^{95}$. A discricionariedade do legislador e do administrador público é, portanto, de natureza instrumental, no sentido de que sempre deve estar voltada ao atendimento do interesse público e dos fins que as normas constitucionais predeterminam e que vinculam todos os Poderes Públicos. Por tal razão, os atos exercidos no âmbito da competência discricionária podem ser sindicados quanto aos fins, motivação e também quanto à observância dos princípios constitucionais da legalidade administrativa, da moralidade pública, da impessoalidade ou isonomia, da eficiência e da publicidade inseridos no art. 37, caput (BRASIL, 1988), bem como da proporcionalidade da razoabilidade e da proibição do excesso (FERRARI, 2001, p. 185) ou da proteção deficiente.

É possível elencar algumas razões ou justificativas para que as normas de direitos fundamentais vinculem a elaboração das leis orçamentárias de forma prioritária. Primeiro, porque consoante assevera Torres (2000, p. 166), os direitos fundamentais têm uma relação profunda e essencial com o orçamento público, sendo dele dependentes para a sua integridade, "ao mesmo tempo em que lhe fornecem o fundamento da legalidade e da legitimidade". Segundo, porque a norma orçamentária é meio necessário para propiciar aos cidadãos o exercício da liberdade fática e por tal razão deve ser elaborada de forma a maximizar a

necessidade pública, assim reconhecida judicialmente, bem como ressalvada a propaganda de produtos e serviços que tenham concorrência no mercado;II - Custear parcial ou integralmente festividades e contratação de shows artísticos, ainda que, por meio de renúncia de receitas ou quaisquer outras formas de fomento; III - Assumir despesa com novos serviços e obras, sem que estejam assegurados os recursos destinados a cumprir obrigação formal preexistente para execução de obra ou serviço já em andamento e com cronograma prefixado, ressalvados os destinados a atender situações de emergência e de calamidade pública; IV - Conceder, majorar ou renovar renúncias de receitas sem lastro na correspondente e indispensável medida compensatória, sobretudo as que são concedidas por prazo indeterminado, diante do seu impacto fiscal desarrazoado em face das premissas contidas no artigo 14 da Lei de Responsabilidade Fiscal; V Reconhecer espontaneamente prescrição da dívida ativa, sem que se tenha buscado esgotar todas as formas lícitas de executá-la, como, por exemplo, o protesto extrajudicial, sob pena de dano ao erário, na forma do artigo 10, X da Lei 8.429/1992” (PINTO, 2019, p. 3-4).

95 Regina Ferrari relembra que, na Alemanha, o Tribunal Federal enfrentou o problema da discricionariedade do legislador e dos seus limites, concluindo que "é uma questão jurídica suscetível de aferição judicial”, estando vedado o excesso de poder. Lado outro, invocando o entendimento do Ministro Gilmar Mendes, Ferrari afirma que "o poder discricionário de legislar contempla, igualmente, o dever de legislar", constituindo uma liberdade "dentro da lei” (FERRARI, 2001, p. 184). 
proteção dos direitos fundamentais ${ }^{96}$. A previsão constitucional de proteção a um direito fundamental seria esvaziada sem a correspondente previsão orçamentária de recursos que permitam efetivar essa garantia de forma suficiente. É por meio do orçamento que se opera juridicamente a conexão entre a previsão legal protetiva de um direito à prestação positiva fática e sua efetivação. Assim, para a proteção dos direitos são necessárias não somente leis delimitando o conteúdo da proteção, mas também previsões orçamentárias aptas a demarcarem os programas específicos que serão executados (LEITE, 2011, p. 18).

$\mathrm{O}$ caminho entre a positivação de um direito fundamental e sua efetivação de forma satisfatória também passa pela elaboração de políticas públicas adequadas e eficazes, que ensejarão a aplicação de recursos públicos suficientes de forma a proporcionar meios materiais para a fruição dessas prestações por todos de que delas necessitarem. Disso decorre que, tanto o Poder Executivo quanto o Poder Legislativo devem tomar decisões que envolvem, desde a escolha dos meios mais eficientes para a concretização das prestações materiais necessárias (dimensão qualitativa), até a análise da suficiência dos recursos disponíveis, de forma a eleger as prioridades de alocações (dimensão quantitativa).

Cristina Queiroz (apud MOREIRA, 2011, p. 129) pontua que a concretização dos direitos fundamentais sociais - os quais demandam a oferta de prestações materiais - estaria intimamente ligada ao progresso alcançado pelos sistemas econômico e social de cada país, uma vez que essas condições influenciam de forma direta a execução da política pública que deve ser implementada, até que se satisfaça plenamente o interesse público que deu origem à sua formulação. Essas políticas públicas demandam uma estrutura normativa e organizacional que delimite a forma e a extensão de prestação dos serviços públicos e da entrega de bens necessários à concretização dos direitos fundamentais sociais. Tal estrutura passa, imprescindivelmente, pela inclusão de recursos suficientes para o custeio dessas prestações, em respeito à norma inserida no artigo 167, inciso I, da Constituição Federal (BRASIL, $1988)^{97}$.

Alinie Moreira (2011, p. 132) ressalta que, mesmo quando existentes, as políticas públicas, em muitos casos, não são capazes de atender à demanda de todos os indivíduos. Essa circunstância pode decorrer da insuficiência de recursos para a concretização das

\footnotetext{
96 A autora afirma, ainda, que no caso brasileiro, um conjunto de compromissos internacionais foram formalmente assumidos que determinam a obrigação dos Estados destinatários de "investirem o máximo de recursos disponíveis na promoção dos direitos previstos em seus textos” (BARCELLOS, 2011, p. 285).

97 "Art. 167. São vedados: I - o início de programas ou projetos não incluídos na lei orçamentária anual" (BRASIL, 1988, CF).
} 
prestações fáticas exigidas pelos direitos fundamentais. Contudo, o respeito à força normativa da Constituição exige a consideração de que, embora possa haver o condicionamento da efetivação dos comandos constitucionais pela realidade fática, a Constituição também orienta as possibilidades jurídicas de atuação dos agentes públicos, dessa mesma realidade de acordo com os valores socialmente eleitos. Dessa forma, a escassez de recursos ou sua insuficiência não desobriga o Estado e seus agentes a concretizar dos comandos veiculados nas normas de direito fundamental, mas sua realização na maior medida possível. Não se trata de uma opção discricionária dos gestores públicos, mas de um dever objetivo do Estado brasileiro, independentemente do governo de ocasião, principalmente quando se trata da garantia de mínimo existencial e do núcleo essencial dos direitos fundamentais.

A dimensão objetiva dos direitos fundamentais promove a irradiação sobre todo o ordenamento jurídico das normas constitucionais que os veiculam. A consequência desse fenômeno é que o sistema jurídico é substancialmente determinado e condicionado pela Constituição. Assim, os direitos fundamentais têm a função de orientar a elaboração do direito infraconstitucional de forma a excluir conteúdos "constitucionalmente impossíveis" e exigir alguns conteúdos "constitucionalmente necessários" (ALEXY, 2015, p. 543). Essa irradiação também deve atingir as decisões tomadas pelo legislador orçamentário e pelo gestor público.

Pode-se afirmar que os limites formais à discricionariedade do legislador orçamentário estão definidos nas normas constitucionais e infraconstitucionais que tratam do processo de elaboração das leis orçamentárias, da forma de aplicação dos recursos públicos, do nível de endividamento do Estado e de outros limites que devem ser observados pelo Poder Legislativo. O Poder Executivo também se submete às inúmeras regras constitucionais e infraconstitucionais para a execução do orçamento. Tais normas constitucionais são regulamentadas, principalmente, pelos dispositivos trazidos pela lei $n^{\circ} 4.320 / 64$ e pela lei complementar $n^{\circ}$ 101/2000 (Lei de Responsabilidade Fiscal).

Uma vez que as normas constitucionais relativas ao sistema orçamentário pouco delimitam o conteúdo das leis orçamentárias, estabelecendo em sua maioria vedações e regras procedimentais, os limites materiais à discricionariedade do legislador serão extraídos das normas constitucionais que veiculam direitos fundamentais. Isso porque o reconhecimento da dimensão objetiva dos direitos fundamentais implica a criação de deveres vinculantes a todos poderes constituídos, impondo-se limites materiais à discricionariedade de destinação de recursos públicos, situação que atinge o legislador orçamentário e os órgãos administrativos encarregados da execução orçamentária. Assim, na elaboração da lei orçamentária não 
somente as regras e princípios orçamentários devem ser observados, mas também as normas que veiculam deveres de efetivação dos direitos fundamentais, no maior patamar possível.

Ávila e Bitencourt (2017, n.p.) corretamente advertem que "nem tudo está resolvido pelo reconhecimento de que os direitos fundamentais oferecem limites à liberdade de disposição orçamentária, pois outros problemas se interpõem entre a previsão legal da verba e sua concretização efetiva". As decisões alocativas no planejamento orçamentário são materializadas em leis orçamentárias, enquanto sua concretização se dá por intermédio da função administrativa exercida por meio de atos administrativos ${ }^{98}$ que demandam motivação suficiente e devem ser baseados em premissas confiáveis. Essas funções deveriam se complementar.

Um problema que se identifica dentro da estrutura orçamentária brasileira é que a lei orçamentária ainda é concebida, na prática, somente como uma "autorização" de gastos públicos, sem caráter de obrigatório, de modo que uma das causas que se aponta para o déficit na "concretização dos direitos econômicos é justamente a ausência de impositividade dos gastos sociais previstos" (ÁVILA; BITENCOURT, 2017, n.p.). Assim, mesmo que haja decisões alocativas do legislador orçamentário que estabeleçam, ab initio, um limite ao que o administrador público pode dispor em determinado exercício financeiro-orçamentário para a efetivação de um determinado direito social e também haja o recurso em caixa, nem sempre essas alocações serão efetivamente executadas. Esses recursos por vezes ficam indisponíveis, não por ausência de previsão orçamentária, mas em razão de limitações impostas por uma decisão de contingenciamento do administrador público durante a execução do orçamento. A escassez de recursos, nesses casos, é provocada por ato administrativo que pode ter sua motivação e legalidade sindicadas, principalmente quando o ato obstar imotivadamente a liberação de recursos para áreas em que ainda não houve a oferta suficiente de prestações fáticas para o atendimento da demanda individual e social de forma a comprometer a proteção do mínimo existencial.

Eduardo Bastos Furtado de Mendonça (2010, p. 175) afirma que há que se ter em conta que as políticas públicas não se justificam por si mesmas, mas destinam-se a realizar os objetivos que são de observância obrigatória aos agentes eleitos, ainda que a sua extensão e

\footnotetext{
${ }^{98}$ Para Sagarbossa: "Vislumbra-se aqui a existência de uma escolha alocativa pelo órgão competente, notadamente pelos órgãos políticos e pela Administração Pública, privilegiando determinados setores com o investimento de recursos que não são escassos por natureza, em detrimento de outros. As escolhas revestem-se de nítido caráter político, eis que os recursos podem ou poderiam ser alocados de diferentes maneiras no caso concreto, segundo as prioridades definidas pelos órgãos com atribuição legal para tanto" (SGARBOSSA, 2010, p. 220).
} 
medida sejam discutíveis. E argumenta:

\begin{abstract}
Na raiz das políticas públicas de saúde ou educação há direitos assegurados pela Constituição e pelas leis, que, como tais não se encontram à disposição das maiorias políticas. A elas cabe a primazia na definição do conteúdo desses direitos e das medidas que devem ser implementadas, mas não se lhes reconhece a faculdade de ignorar a sua existência ou de concretizar tais comandos abaixo de certo patamar mínimo, que tenderá a ser identificável mesmo a partir de enunciados dotados de textura abeta, como o direito à saúde e à moradia (MENDONÇA, 2010, p. 175-176).
\end{abstract}

$\mathrm{Na}$ apuração da confiabilidade da premissa empírica do princípio da reserva do possível - relativamente à dimensão jurídica da escassez - importa aferir se existe ou não de um dever dirigido ao Poder Executivo de disponibilizar/executar o montante das verbas públicas da forma estabelecida pelo Poder Legislativo. Essa análise demanda um conhecimento básico da dinâmica orçamentária, o que passará a ser abordado a seguir.

\title{
3.2 O TRATAMENTO JURÍDICO-CONSTITUCIONAL DAS NORMAS ORÇAMENTÁRIAS
}

De maneira geral, a noção de orçamento está atrelada à ideia de um planejamento das finanças públicas, das receitas e despesas estatais, durante determinado período. Uadi Lammêgo Bulos (1998, p. 283) afirma que orçamento é “o instrumento que documenta a atividade financeira do Estado, contendo a receita e o cálculo das despesas autorizadas para o funcionamento dos serviços públicos e outros fins projetados pelos governos".

Inicialmente, o orçamento teria sido concebido como um documento contábil que materializava uma mera autorização de gastos. Contudo, para Bulos (1998, p. 284), com a evolução das sociedades de massa e com a crescente intervenção estatal na economia, o orçamento passou a refletir uma realidade mais ampla, agregando outros elementos em seu conteúdo, "além daqueles de índole contábil, exteriorizados pela estimativa da receita e pela autorização da despesa”. Dessa forma, o orçamento pode ser definido como:

O instituto de caráter jurídico, governamental, econômico e técnico, traduzido numa lei, cuja responsabilidade é programar, planejar e aprovar obras, serviços e encargos públicos, bem como estipular plano financeiro anual para as entidades constitucionais, com previsão da receita e autorização da despesa (BULOS, 1998, p. 284). 
O sistema orçamentário é disciplinado pelas normas constitucionais inseridas na Seção II, do Capítulo das Finanças Públicas (BRASIL, 1988, CF) e em dispositivos esparsos no texto constitucional. Trata-se, entre outros, das regras e princípios orientadores da elaboração das leis orçamentárias e das alocações, das vedações e limites de gastos, do procedimento de aprovação das leis orçamentárias, das competências e do controle externo. O que se denomina de "orçamento público" é, na verdade, um conjunto normativo, estruturado com base em três leis, consoante estabelecido no artigo 165 da Constituição Federal ${ }^{99}$ (BRASIL, 1988) ${ }^{\circ}$ Plano Plurianual (PPA) ${ }^{100}$, a Lei de Diretrizes Orçamentárias (LDO) ${ }^{101}$ e a Lei Orçamentária Anual $(\mathrm{LOA})^{102}$. Todas as leis orçamentárias são de iniciativa formal do Poder Executivo e possuem funções específicas ${ }^{103}$.

Fernando Facury Scaff (2018, p. 243) destaca que, quando se trata de "lei orçamentária", há que se ter em mente tanto a fase de planejamento, quanto a fase de execução. Por tal razão, não somente as três leis orçamentárias (PPA, LDO e LOA) fazem parte do sistema de planejamento orçamentário. Para o autor, quando se tratar de orçamento público deve-se também levar em consideração todas as leis posteriores que modificam e ajustam, durante a sua execução, o conteúdo das leis orçamentárias inicialmente aprovadas para o exercício financeiro. Essa alteração ocorre por meio de dos mecanismos jurídicos de

99 “Art. 165. Leis de iniciativa do Poder Executivo estabelecerão: I - o plano plurianual; II - as diretrizes orçamentárias; III - os orçamentos anuais” (BRASIL, 1988, CF).

100 O PPA tem a função de concretizar a política pública através dos programas que estabelecem as diretrizes, objetivos e metas a serem alcançados pela Administração Pública, referentes às despesas de capital e programas de duração continuada, por mais de um exercício financeiro. Seu planejamento abrange um período de quatro anos e essa programação abrange o segundo ano do governo atual, até o primeiro ano do governo subsequente (art. 35, §2 , I, do ADCT [Citação ABNT]). Os planos e programas setoriais e regionais previstos na Constituição devem guardar consonância com o conteúdo do PPA, conforme determina o art. $165, \S 4^{\circ}$, da Constituição Federal (BRASIL, 1988).

101 A LDO também está prevista em norma constitucional e ainda possui disciplina específica na Lei $n^{\circ} \mathrm{XX}$ (BRASIL, XX), denominada Lei de Responsabilidade Fiscal, que determina, dentre outras regras, a elaboração de três anexos para comporem a LDO: o de Metas Fiscais, o de Riscos Fiscais e outro que trate da indicação dos objetivos das políticas monetária, creditícia e cambial, os parâmetros e projeções para os principais agregados e variáveis, e as metas de inflação (SCAFF, 2018, p. 241).

102 A Lei Orçamentária Anual (LOA) é o dispositivo legal que contém efetivamente as receitas e despesas para um exercício financeiro e será enviada ao Legislativo até 31 de agosto de cada ano e aprovada até o final da sessão legislativa, nos termos do artigo 57 da Constituição Federal (BRASIL, 1988).

${ }^{103}$ Quanto à iniciativa da lei orçamentária não são admitidos para sua aprovação projetos de lei de iniciativa popular, lei delegada, medidas provisórias ou o mecanismo do plebiscito, conforme artigo 14, I, II e III; artigo 68, $\S 1^{\circ}$ e artigo $62 \S 1^{\circ}$, I, “d” da Constituição Federal (BRASIL, 1988) (SCAFF, 2018, p.235). Os Poderes Legislativo e Judiciário, o Ministério Público, Tribunais de Conta e Defensoria Pública gozam de autonomia financeira e devem encaminhar sua programação orçamentária, dentro dos parâmetros e limites constitucionais, ao Chefe do Executivo, que é responsável pela consolidação em peça única. 
flexibilização orçamentária ${ }^{104}$.

Bulos (1998, p. 286-287) informa que também há que ser considerada na composição desse sistema orçamentário a lei complementar prevista no art. $165, \S 9^{\circ}$, incisos I e II da Constituição Federal (BRASIL, 1988), que estabeleceria as normas gerais de direito financeiro, orientando a feitura das demais leis orçamentárias. Essa lei seria permanente, ao contrário das demais leis orçamentárias, que têm vigência temporária. Enquanto a lei complementar não for editada, vigorará a Lei Federal n 4.320/64, que dispõe sobre finanças públicas, exercício financeiro, vigência, prazos, elaboração e organização de planos, diretrizes, atos normativos orçamentários, no que não for contrária aos dispositivos constitucionais.

Atualmente, existe a exigência constitucional de que tanto as três leis orçamentárias apresentem compatibilidade entre si, quanto emendas ao projeto de lei orçamentária anual (LOA) guardem consonância ao projeto de lei de diretrizes orçamentárias (LDO) (BRASIL, 1988, art. 166, $\S 3^{\circ}$ e $\left.\S 4^{\circ}\right)$. Em relação à realização de despesas, Scaff $(2018$, p. 239) afirma que essa compatibilidade é reforçada nos art. $16, \S 1^{\circ}$, II e art. $17, \S 4^{\circ}$, da Lei Complementar $n^{\circ} 101$ (BRASIL, 2000), denominada Lei de Responsabilidade Fiscal (LRF).

A Constituição inaugura no sistema jurídico a ideia de orçamento-programa, que se extrai a partir da "nítida preocupação em se fixar um planejamento de estruturas, pois todos estes planos e programas nacionais, regionais e setoriais, que são apreciados pelo Congresso Nacional, devem estruturar-se de acordo com o plano plurianual (art.165, $\S 4^{\circ}$ )" (BULOS, 1998, p. 290) ${ }^{105}$. Pela disciplina constitucional, o correto seria falar em "orçamentos", uma vez que da dicção do artigo 165, (BRASIL, 1988), são previstas “as seguintes espécies do gênero orçamento público: orçamento financeiro, orçamento plurianual, orçamento das diretrizes, orçamento anual, compreendendo este o orçamento fiscal, o orçamento de investimento e o orçamento da seguridade social” (BULOS, 1998, p. 286, itálico no original).

${ }^{104}$ Dentre os mecanismos de flexibilização orçamentária, destacam-se os créditos adicionais previstos no artigo 40, da Lei $n^{\circ} 4.320$ (BRASIL, 1964), o contingenciamento ou limitação de empenho e movimentação financeira (art. $9^{\circ}$, da Lei Complementar $\mathrm{n}^{\circ} 101$ (BRASIL, 2000) a reserva de contingência, prevista no artigo 91, do Decreto-Lei 200 (BRASIL, 1967) e os instrumentos de remanejamento, transferências e transposição de recursos previstos no artigo $167, \S 5^{\circ}$ (BRASIL, 1988) e artigo $7^{\circ}$, I, da Lei ${ }^{\circ} 4.320$ (BRASIL, 1967).

105 Bulos (1998, p. 290) acrescenta que dessa estrutura de planejamento revela o liame entre o orçamento público e o fator econômico, estudado por Keynes. "Este elo entre ambos fornece-nos a compreensão orçamentoprograma na Constituição, pois garante a coordenação necessária entre a política físcal (intervencionismo indireto) e a política econômica (intervencionismo direto), proporcionando o equilíbrio financeiro com o equilíbrio econômico geral, integração esta relevante e indispensável, não sendo mera justaposição de planos, mas uma vinculação permanente e continuada, "que não admite interrupção, de sorte que os planos mais gerais ou globais abrangem os mais concretos e a execução destes leva à materialização daqueles'" (BULOS, 1998, p. 290). 
As leis orçamentárias informam à sociedade as decisões políticas sobre as metas e prioridades eleitas para as ações estatais, em determinado período de tempo, "de forma a evidenciar a política econômica financeira e o programa de trabalho do governo" (BRASIL, 1964, art. $2^{\circ}$ ) mediante as alocações orçamentárias a elas destinadas, possibilitando seu controle democrático por meio dos instrumentos de transparência previstos na Lei de Responsabilidade Fiscal e do controle externo a cargo do Congresso Nacional, com o auxílio do Tribunal de Contas (BRASIL, 1988, art. 71).

No que se refere à análise da vinculatividade do Poder Executivo ao que foi estabelecido nas leis orçamentárias, a discussão adentra em uma tormentosa seara que se relaciona ao debate teórico sobre o caráter autorizativo ou impositivo do orçamento público. Por sua vez, esse debate tem como base a discussão sobre a natureza meramente formal ou material da lei orçamentária ${ }^{106}$.

Ferreira (2018) relembra que essa controvérsia tem raízes na formulação teórica de Paul Laband, em sua obra "Direito Orçamentário" (1871). O autor afirmava que o orçamento público, apesar de veiculado na forma de lei, consistiria em uma mera autorização do Poder Legislativo ao Executivo para gastar até determinado limite ${ }^{107}$. Em consequência, na fase de execução do orçamento, o Executivo poderia tomar quaisquer decisões, uma vez que a matéria estaria inserida em sua competência exclusiva. As alterações que o Executivo promovesse ao longo da execução orçamentária não seriam um problema, pois se trataria apenas de alterações de um documento contábil, sem efeitos gerais e abstratos. Não haveria sequer a necessidade de fundamentar as retenções (MENDONÇA, 2010, p. 74). Sua responsabilidade seria apenas perante o parlamento, de natureza política e não jurídica ${ }^{108}$.

106 Francisco G. B. Carvalho Ferreira (2018, p. 68) resume a discussão sobre quais os efeitos da lei orçamentária produzidos após sua aprovação e sanção, com a seguinte indagação [Isso não é uma indagação, é uma afirmação. Está um pouco confuso.]: "Em outros termos: o orçamento público é lei material, gerando direitos subjetivos e vinculando sua realização (caráter impositivo), ou, por ser um instrumento estatal de cunho programático, tem a lei orçamentária uma natureza diversa, relacionando-se à mera autorização para realizar gastos públicos, mas sem produzir direitos subjetivos nem vincular o poder público ao seu efetivo cumprimento.

107 Segundo Ferreira (2018, p. 69), os pilares da discussão sobre a natureza jurídica do orçamento encontram-se nas posições defendidas por Paul Laband, Gaston Jèze, Léon Duguit e Myrbah-Rheinfeld. Suas posições são as seguintes: a) teoria da lei formal (Laband), segundo a qual o orçamento é lei somente em sentido formal; b) teoria do ato-condição (Gaston Jèze), segundo a qual o orçamento é condição para alocação dos recursos, sendo apenas uma lei formal; c) teoria da lei "sui generis" (León Duguit), pela qual o orçamento é mero ato administrativo no que se refere às despesas e lei em sentido material no tangente às receitas; d) teoria da lei material (Myrbah-Rheinfeld), segundo a qual o orçamento é lei tanto em sentido formal quanto em sentido material, não havendo que se questionar sobre sua substância, uma vez que originária do órgão legiferante.

108 As teorias formalistas, como a de Laband, concebem que os efeitos jurídicos da lei orçamentária não seriam os mesmos de uma lei em sentido material. O orçamento aprovado seria meramente um ato de previsão e de autorização da receita e da despesa pública para um determinado período. 
Mendonça (2010, p. 75) esclarece que essa teoria tem servido ao objetivo de negar que direitos subjetivos possam ser extraídos da lei orçamentária e embasar pretensões em face do Estado. "O orçamento funcionaria como formalidade necessária, como pressuposto para a realização da despesa pública. A efetiva liberação dos recursos, porém, ficaria a critério do Poder Executivo".

Ferreira (2018, p. 72-73) afirma que a posição doutrinária majoritária no Brasil defende que o orçamento teria natureza autorizativa, no sentido de que "o fato de a verba estar nele prevista não obriga à sua realização, nem confere, de pronto, direito subjetivo ao seu recebimento". Portanto, a destinação da verba pública seria considerada apenas uma “intenção política”, permitindo, portanto, sua inexecução imotivada. Segundo Leite (2011, p. 66), os que defendem a natureza autorizativa do orçamento público se baseiam na afirmação de que o texto constitucional teria utilizado em alguns dispositivos ${ }^{109}$ a palavra "autorização" para ser referir ao ato do legislativo em relação a algumas despesas. Contudo, o autor afirma que essa expressão foi utilizada em situações específicas, excepcionando outras normas, do que se infere que existe um dever de execução orçamentária nos moldes aprovados pelo Poder Legislativo e que as exceções tiveram que ser explicitadas.

Contudo, entende-se que a concepção do orçamento público como lei meramente formal, embora ainda encontre grandes defensores, apresenta dissonância com o texto constitucional brasileiro. Primeiro, porque conforme se depreende da diç̧ão do art. 59 (BRASIL, 1988, CF) e seus incisos - que trata do processo legislativo brasileiro -, a Constituição de 1988 não acolheu a distinção das espécies normativas como leis materiais ou leis formais. No Brasil, a lei ou é lei ordinária, ou lei complementar ou lei delegada, cuja diferenciação não se dá pela força normativa, mas por matéria e pelo procedimento legislativo.

A adoção desse entendimento levaria também à conclusão de que qualquer dispositivo que eventualmente que determinasse a obrigatoriedade de alguns gastos ou permitisse emendas ao projeto de lei orçamentária - que é de iniciativa do Poder Executivo - seria inconstitucional, por desvirtuar o que foi proposto por esse Poder, em ofensa ao princípio da separação dos poderes. Ocorre que se pode argumentar justamente ao contrário em relação à

109 Dentre os dispositivos constitucionais que fazem referência à palavra "autorização", podem ser citados: "Art. $165, \S 8^{\circ}$. A lei orçamentária anual não conterá dispositivo estranho à previsão da receita e à fixação da despesa, não se incluindo na proibição a autorização para abertura de créditos suplementares e contratação de operações de crédito, ainda que por antecipação de receita, nos termos da lei" (BRASIL, 1988, CF). Também: "Art. 167. São vedados: [...] V - a abertura de crédito suplementar ou especial sem prévia autorização legislativa e sem indicação dos recursos correspondentes" (BRASIL, 1988, CF). 
violação do princípio da separação dos poderes. Isso porque a defesa do caráter meramente autorizativo da lei orçamentária permite que as decisões politicamente produzidas no processo deliberativo democrático sejam inteiramente esvaziadas e substituídas por decisões unilaterais e imotivadas do Poder Executivo. Do mesmo modo, permite que políticas públicas relevantes, eleitas pelo processo majoritário, sejam desconsideradas (MENDONÇA, 2010, p. 90-91).

A Constituição não quedou inerte quanto à possibilidade de haver imprevistos e concedeu uma margem de flexibilização na execução do orçamento. Para tanto, instrumentos de flexibilização orçamentária foram instituídos, tais como: os créditos suplementares (que visam a reforçar dotações insuficientes), os créditos especiais (que permitem a realização de despesas não previstas inicialmente na lei orçamentária) e os créditos extraordinários (que possibilitam fazer frente às despesas urgentes e imprevisíveis). Contudo, verifica-se que nessas hipóteses, em que o Poder Executivo teve permissão constitucional para alterar as opções orçamentárias originais, foram expressamente previstas tanto na Constituição quanto na Lei de Responsabilidade Fiscal e dependem, como regra, de nova autorização legislativa (com exceção dos créditos extraordinários), podendo constituir crime de responsabilidade sua inobservância.

A possibilidade de flexibilizar a execução orçamentária por meio dos instrumentos constitucionalmente previstos não torna o orçamento meramente autorizativo. A dependência de nova autorização legislativa como regra para as alterações orçamentárias denota que o Executivo não pode alterar ao seu arbítrio o que foi democraticamente aprovado para o orçamento, permitindo-se, desse modo, o questionamento judicial da alteração realizada. $\mathrm{O}$ reconhecimento de que o orçamento público constitui um instrumento de Estado para a concretização dos direitos fundamentais e para a consolidação da democracia também fomentou os argumentos a favor de um maior grau na sua impositividade ao Poder Executivo (FERREIRA, 2018, p. 72-73).

Inicialmente, a posição tradicional do Supremo Tribunal Federal (STF) encontrava-se no sentido da impossibilidade de impugnação em sede de controle abstrato de constitucionalidade do orçamento público em razão da natureza de lei formal e por ser norma de "efeitos concretos"" (FERREIRA, 2018, p. 117). Esse entendimento começa a ser modificado também na jurisprudência do STF, a partir de 2003, na ADI n ${ }^{\circ}$ 2.925/DF, de

110 Lei de efeito concreto consiste naquela que, por exigência formal, ingressam no ordenamento jurídico por meio de um procedimento legislativo formal, mas veicula conteúdo direcionado a sujeitos individualizáveis e não mandamentos genéricos ou abstratos. 
relatoria da Ministra Ellen Gracie. Na ocasião, “ficou assentada a possibilidade de a lei orçamentária trazer densidade normativa abstrata suficientemente hábil a ensejar ação de controle, cabendo o exame de constitucionalidade, mesmo em sendo lei formal de efeitos concretos", entendimento este que foi consolidado posteriormente em outros julgados do Supremo Tribunal Federal (FERREIRA, 2018, p. 116).

Posteriormente, no julgamento da medida cautelar na ADI n 4.048/DF, de relatoria no ministro Gilmar Mendes, o Supremo Tribunal Federal reviu sua orientação a respeito do tema e passou a admitir o controle de constitucionalidade das leis orçamentárias, em sede abstrata, independentemente do caráter geral ou específico, concreto ou abstrato de seu objeto. Corroborando o novo entendimento, o STF também se manifestou no mesmo sentido, na medida cautelar decidida no âmbito da ADI $n^{\circ} 4.049 / \mathrm{DF}$, de relatoria do ministro Carlos Britto, reforçando o posicionamento acerca da legitimidade do controle de leis orçamentárias (FERREIRA, 2018, p. 116-117).

Uma posição intermediária pode ser encontrada em parte da doutrina que defende a natureza híbrida do orçamento. Isso porque uma parte das normas constitucionais orçamentárias seria impositiva (vinculante) e outra, seria autorizativa. Esse argumento se desenvolve a partir da constatação de que existe certo grau de rigidez do orçamento no âmbito da União, que limita a discricionariedade do administrador público na elaboração e execução orçamentária. Nesse sentido, Silveira (2015, p. 65-66) constata que um elevado percentual de receitas já se encontra comprometido com rubricas predeterminadas, divididas em dois arranjos normativos: as despesas obrigatórias (e quase obrigatórias) e as receitas vinculadas.

A vinculação dessas receitas foi escolha política, em âmbito constitucional, especialmente visando a resguardar mecanismos de financiamento e custeio dos direitos fundamentais. Dentre as receitas vinculadas, o autor cita aquelas advindas de contribuições, cuja destinação justifica sua instituição, não podendo ser aplicadas em outras áreas. Por sua vez, as despesas obrigatórias encontram-se disciplinadas em normas constitucionais que determinam os valores mínimos (pisos) a serem aplicados na área da saúde (BRASIL, 1988, art. 198, $\$ 3^{\circ}$ e $\S 2^{\circ}$ ) e de educação (BRASIL, 1988, art. 212), as despesas correntes obrigatórias (como as despesas com o pagamento dos servidores públicos) e o pagamento dos juros da dívida ${ }^{111}$.Assim, para esses autores, já haveria uma reduzida margem de

${ }^{111}$ No mesmo sentido, defende Venâncio (2018, p. 127): as vinculações constitucionais de percentuais mínimos de gastos com saúde e educação e de emendas parlamentares, até atingir o mínimo, tornam a LOA impositiva e não meramente autorizativa. Despesas obrigatórias e contínuas como o gasto com pessoal, no caso 
discricionariedade do Executivo para deixar de executar as despesas inicialmente estabelecidas na LOA ou para alterar o conteúdo das dotações orçamentárias, restringindo-se às denominadas despesas discricionárias, estas, sim, teriam um caráter autorizativo.

Constata-se, ainda, que o caráter vinculante do orçamento vem sendo reforçado no sistema jurídico-constitucional por meio de sucessivas emendas constitucionais. A Emenda Constitucional $\mathrm{n}^{\mathrm{o}} 86$ (BRASIL, 2016), que trouxe alterações importantes no texto constitucional, expressamente estabelece a impositividade para a execução das emendas parlamentares individuais, na medida em que torna obrigatória a execução da programação orçamentária que essas emendas dispõem, salvo nos casos especificados. Assim, passa a exigir justificativa para o contingenciamento dos recursos empenhados para tais emendas, o que será feito por projeto de lei encaminhado pelo Executivo ao Legislativo e não mais por mero ato administrativo (LOCHAGIN, 2016, p. 2.686).

No mesmo sentido, a Emenda Constitucional $n^{0} 100$ (BRASIL, 2019) amplia a impositividade às emendas de bancadas, com a ressalva de que só não haverá execução obrigatória nos casos de impedimentos de ordem técnica que não permitam a realização do empenho da despesa (BRASIL, 1988, art. 166, §13). Mas a principal alteração introduzida pela EC nº 100 (BRASIL, 2019) no sistema jurídico-constitucional brasileiro em relação ao tema foi a inserção do parágrafo 10 , no artigo 165 , da Constituição Federal, que recebeu a seguinte redação:

Art. 165. [...]

§10. A administração tem o dever de executar as programações orçamentárias, adotando os meios e as medidas necessários, com o propósito de garantir a efetiva entrega de bens e serviços à sociedade (BRASIL, EC n.100, 2019).

Esta mudança no texto constitucional torna insustentável defender o caráter meramente "autorizativo" do orçamento público no ordenamento jurídico brasileiro, porque reconhece, de maneira expressa, o modelo de execução obrigatória integral do orçamento público, na medida em que não discrimina quais as programações a que se refere esse dever, abrangendo, portanto, todas as despesas ${ }^{112}$. Esse dever somente seria excepcionado por

concreto, eliminam qualquer resquício de discricionariedade do Administrador.

112 Nesse sentido também é o entendimento de Marcus Abraham (2019, p. 2): "não obstante sempre termos nos manifestado pela obrigatoriedade da execução orçamentária na sua integralidade desde o texto original da Constituição Federal de 1988 (exceto nos casos de restrições financeiras, legais, técnicas ou materiais), a nós nos parece que esta mudança constitucional afasta de vez qualquer dúvida sobre o caráter meramente 'autorizativo' do orçamento público, como muitos sustentavam, e reconhece, de maneira expressa e literal, o 
questões de impossibilidade técnica.

Parte do orçamento constitui-se de receitas vinculadas cuja destinação não pode ser alterada, a exemplo dos fundos públicos. Outra grande parte é formada de despesas constitucionalmente obrigatórias como os percentuais mínimos de gastos estabelecidos constitucionalmente com as áreas da saúde e de educação, despesas obrigatórias como as despesas com salários e encargo de servidores públicos. Por fim, inclui-se nesse rol o serviço da dívida pública. Todas essas situações limitam a discricionariedade do legislador tanto na elaboração do projeto de lei orçamentária quanto do administrador na execução do orçamento aprovado de destinação dos recursos públicos.

Considerando que os gastos obrigatórios já possuíam uma natureza de dever, alguns autores concluem que o novo dispositivo vem reforçar a ideia da obrigatoriedade de execução das despesas discricionárias, a que são destinadas as emendas parlamentares. Conclui-se que há fundamento constitucional para defender um dever objetivo de execução das disposições das leis orçamentárias, extraído de uma norma constitucional expressa, pois as exceções já foram explicitamente consignadas no texto constitucional. A alteração da estrutura dos gastos originalmente aprovados de forma democrática pelo Legislativo que não passar pelos instrumentos jurídicos de flexibilização previstos na Constituição e na Lei de Responsabilidade Fiscal, bem como a inércia imotivada no âmbito da execução orçamentária, podem ser, portanto, judicialmente sindicáveis para se exigir o devido cumprimento do dever estipulado.

Uma natureza de normas "não vinculantes" é incompatível com o estabelecimento de sanções para o descumprimento de normas orçamentárias e, mais ainda, incompatível com o próprio conceito de normas jurídicas. Conclui-se, pois, que das leis orçamentárias podem ser extraídos deveres objetivos vinculantes, sejam de caráter prima facie sejam de caráter definitivo, a depender da norma em que são fundamentados ${ }^{113}$.

Contudo, mesmo com as alterações introduzidas pela EC nº 86 (BRASIL, 2015) e

modelo de execução obrigatória integral do orçamento público, tradicionalmente conhecido por 'orçamento impositivo"".

113 Ademais, em nosso ordenamento jurídico, inúmeras normas preveem sanções para o descumprimento de regras orçamentárias. A exemplo, pode ser citado o artigo 85, inciso V, da Constituição Federal (BRASIL, 1988) que estabelece que são crimes de responsabilidade os atos do Presidente da República que atentem contra a Constituição Federal e, especialmente, contra: a lei orçamentária. De igual modo, na legislação infraconstitucional, pode ser citado o artigo 73, da LRF, o qual prevê que as infrações aos dispositivos daquela lei serão punidas segundo o Código Penal brasileiro (BRASIL, 1940); Lei n ${ }^{\circ} 1.079$ (BRASIL, 1950), denominada Lei dos Crimes de Responsabilidade; a Lei n ${ }^{\circ} 8.429$ (BRASIL, 1992), denominada Lei de Improbidade Administrativa; Decreto-Lei no 201 (BRASIL, 1967), que_trata da responsabilidade de Prefeitos e Vereadores e demais normas da legislação pertinente. 
pela EC n ${ }^{\circ} 100$ (BRASIL, 2019), ainda se propaga que a mudança trazida pela norma não diluiu a celeuma da facultatividade versus impositividade (AVILA, BITENCOURT, 2017, n.p.). Nesta pesquisa, conclui-se, após a nova redação do artigo $165, \S 10$, da Constituição Federal (BRASIL, 1988), pelo caráter vinculante das normas orçamentárias, sendo, portanto, os atos administrativos que concretizam a execução orçamentária plenamente justiciáveis.

\subsection{O PRINCÍPIO DA RESERVA DO POSSÍVEL E OS DESVIOS DE PODER ORÇAMENTÁRIO}

Os desvios ou vícios orçamentários ${ }^{114}$ constituem obstáculos substanciais à aferição da efetiva limitação orçamentária. São perpetrados mediante atos administrativos revestidos de uma aparência de legalidade, mas que, materialmente, estão desconformes com o ordenamento jurídico. O vício do desvio de poder, em geral, ocorre quando a autoridade administrativa se vale do poder que lhe foi constitucionalmente conferido para alcançar um objetivo diferente daquele estabelecido por lei, colocando em prática um provimento diferente de sua função típica institucional (VENÂNCIO, 2016, p. 15).

A análise das possibilidades fáticas na ponderação do princípio da reserva do possível exige a consideração da realidade financeira estatal. Não há como olvidar que a confiabilidade dessa análise dependerá de que esse procedimento seja feito com base em um orçamento real e "que verdadeiramente indique o que está sendo feito pelo Poder Público e a que custo" (MENDONÇA, 2010, p. 173).

Venâncio (2016, p. 181) esclarece que a existência dos desvios orçamentários pode implicar, na prática, a execução de um orçamento paralelo ${ }^{115}$, diverso do que foi autorizado pelo Poder Legislativo. O autor afirma que isso pode ocorrer porque

[...] há margem de atuação ao administrador na execução do orçamento, principalmente porque sempre terá dotações para anular, total ou parcialmente, para respaldar a abertura de créditos adicionais em face da expectativa artificial de entrada de recursos sem concretização, dando enorme margem de manipulação com esteio em dados irreais de entrada de receita, acabando sempre na realização de despesas sem base financeira e instituindo novas dívidas, comprometendo

114 O termo "desvio orçamentário" ou "desvio de poder orçamentário" será utilizado nesta pesquisa no sentido de qualquer ato praticado pelo Poder Público que incida em ilegalidade ou desvio de poder no âmbito do planejamento ou da execução orçamentária.

115 Outro exemplo: “A sobrevalorização da previsão de receita, que se sabe que não se efetivará constitui um dos métodos mais comuns para facilitar o desvio de poder orçamentário, criando um orçamento paralelo" (VENANCIO, 2016, p. 181). 
orçamentos futuros em detrimento do princípio do equilíbrio orçamentário (VENÂNCIO, 2016, p. 181-182).

Esses mecanismos podem restringir (de forma não autorizada pelo ordenamento jurídico) as possibilidades de efetivação de um direito fundamental. Isso porque, caso não tivesse ocorrido determinada ilegalidade ou desvio de poder, a insuficiência orçamentária poderia não ter ocorrido e o princípio da reserva do possível não seria aplicável ao caso.

SILVEIRA (2014, p. 80) adverte que o contingenciamento não pode alcançar os denominados gastos ou despesas obrigatórias, mas somente poderia recair sobre despesas discricionárias. $\mathrm{O}$ autor fundamenta essa afirmação na própria conceituação de contingenciamento formulada pela Secretaria de Orçamento Federal que de forma expressa refere-se à possibilidade de contingenciar somente despesas discricionárias ou não legalmente obrigatórias ${ }^{116}$.

Em termos gerais, pode-se afirmar que a execução da lei orçamentária tem os mesmos objetivos da execução de qualquer lei (LORETTO, 2016, p. 1.259). O exercício da atividade administrativa concretizadora da execução orçamentária demanda a prática de atos administrativos. Melhor esclarecendo:

\begin{abstract}
A LOA se executa por meio de atos e procedimentos administrativos, tais como: empenho de despesa; nota de empenho; liquidação de despesa; ordem de pagamento; abertura de créditos adicionais, suplementar e especial. Estados e Municípios que não editam medidas provisórias, ainda abrem créditos extraordinários, por meio de decreto. O contingenciamento de despesa também se dá por meio de decreto; as operações de crédito, empréstimos e endividamento público são processadas mediante atos administrativos ou atos da Administração Pública. A arrecadação de receitas se vale de lançamento, que são procedimentos administrativos (VENÂNCIO, 2016, p. 131).
\end{abstract}

Esses atos administrativos praticados na fase de execução deverão ter conteúdo adstrito aos limites da lei inicialmente aprovada, conforme artigo 165, §10, da Constituição Federal (BRASIL, 1988) e os parâmetros mínimos constitucionalmente delimitados. É também em norma constitucional que se encontra previsto o dever do Presidente da República

\footnotetext{
116 Silveira (2014, p. 80) traz a definição de contingenciamento extraída do site oficial da Secretaria do Orçamento Federal, o qual consistente "no retardamento ou, ainda, na inexecução de parte da programação de despesa prevista na Lei Orçamentária em função da insuficiência de receitas". E esclarece que "no início de cada ano, o Governo Federal emite um Decreto limitando os valores autorizados na LOA, relativos às despesas discricionárias ou não legalmente obrigatórias (investimentos e custeio em geral)".
} 
de "expedir decretos e regulamentos para sua fiel execução" (BRASIL, 1988, art. 84, IV), o que, em princípio não admite seu desvirtuamento imotivado. Sobre os desvios do ato administrativo, Leite afirma que:

\begin{abstract}
Ato individual e concreto discrepante da norma significa apenas que o ato foi efetuado sem o amparo jurídico. Trata-se de ato irregular, que deve ser, dentro do período de tempo previsto pelo Direito, revogado ou anulado. Afirmação em sentido contrário mostra-se flagrante retrocesso da doutrina dominante, pois analisa $\mathrm{o}$ orçamento apenas do ponto de vista da ciência financeira, como atividade prénormativa, pertencente mais ao mundo da economia e dos fenômenos sociais que ao mundo jurídico. Cada ação deve ser meticulosamente analisada a fim de averiguar seu ajuste ao prescrito no orçamento, tendo em vista que a Administração está obrigada a agir de acordo com a lei, no caso, a lei orçamentária. Se, porventura, o Executivo age diferentemente da lei que lhe ordenou (LOA), diz-se que agiu com desvio de finalidade. Do mesmo modo, cabe o raciocínio para determinação judicial impositiva de gasto não previsto no orçamento, uma vez que, se realizado, significa desvio de finalidade, pois aplicou recursos em fins diversos dos previstos em lei (LEITE, 2011, p. 69).
\end{abstract}

Especialistas chamam a atenção para a utilização do orçamento como meio de barganha pelo qual Poder Executivo pressiona os integrantes do Poder Legislativo para votar de acordo com seus interesses. Os ministérios são ocupados por indicações de partidos políticos com os quais são negociadas as prioridades para a pasta. Segundo o autor, os mecanismos na execução orçamentária que mais costumeiramente têm sido utilizados para essa finalidade são: a implementação seletiva do orçamento e a execução dos Restos a Pagar (LIMA, 2015, p. 141).

A prevalência do entendimento de que o orçamento não apresenta execução obrigatória nos moldes aprovados pelo Poder Legislativo dá um espaço de ação para o Poder Executivo efetivar, preferencialmente, as emendas individuais dos parlamentares que apoiam o governo nos projetos do seu interesse. No segundo caso, o Legislativo amplia artificialmente as receitas na Lei Orçamentária Anual (LOA), permitindo que o Poder Executivo execute parte das emendas parlamentares que selecionar e inscreva em Restos a Pagar a outra parcela. Esse artifício é possível porque o ato de empenhar despesas não implica que as mesmas serão pagas no mesmo exercício. A despesa pode ser empenhada e até liquidada em um exercício, mas o pagamento pode ser adiado pelo período de tempo estabelecido no cronograma segundo a conveniência do Executivo (LIMA, 2015, p. 142).

O que é politicamente conveniente pode não ser juridicamente sustentável, como no caso dos contingenciamentos fora das hipóteses legais, em prejuízo da efetivação das 
prestações concretizadoras dos direitos fundamentais. Esse é um grande problema que se levanta com a defesa de um caráter autorizativo do orçamento e que Mendonça denominou de “o poder de não fazer nada” (MENDONÇA, 2010, p. 78). Sustentar tal prerrogativa reforça um desprestígio da lei, que Binenbojm denominou de "deslegalização", a qual se refere à cada vez maior autonomia normativa atribuída ao Executivo e seus decretos (GOMES, 2013, p. 89).

A Constituição não autoriza ao Poder Executivo modificar livremente o que foi estabelecido na lei orçamentária, bem como não autoriza a realização de despesa sem previsão orçamentária formal. Contudo, Mendonça (2010, p. 79) adverte que há um silêncio em relação à decisão de não gastar e que quando o Poder Executivo não libera as verbas referentes à determinada dotação orçamentária ou não efetiva seu remanejamento, parte da receita arrecadada fica em um "limbo orçamentário". Ocorre que o que justifica a arrecadação é justamente o destino que será dado aos recursos, de modo que todos os recursos devem receber alguma destinação (MENDONÇA, 2010, p. 83). A decisão de não gastar, portanto, não está sujeita à vedação expressa na Constituição. Contudo, o autor reforça que essa decisão não é banal e deveria ser motivada, porque uma atividade tão relevante quanto o complexo e democrático procedimento de elaboração e aprovação do orçamento não poderia ser superado por conveniência política unilateral, sem a devida motivação (MENDONÇA, 2010, p. 81-82).

O contingenciamento de despesas ou limitação de empenho e de movimentação financeira, embora seja mecanismo amplamente utilizado pelo Poder Executivo, tem sua previsão somente para uma única hipótese na Lei de Responsabilidade Fiscal (LRF) ${ }^{117}$, o que denota que sua aplicação para outros fins é, no mínimo, questionável. Somente quando o contingenciamento for devidamente motivado, com razões fortes o suficiente para justificar a interferência no direito fundamental, não se tratará de uma violação inconstitucional, o que somente poderá ser aferido no caso concreto e a partir de uma motivação.

Em obra específica sobre o tema, intitulada "Desvio de Poder Orçamentário", Denilson Venâncio (2016, p. 159-161) traz um levantamento minucioso sobre as possíveis modalidades de desvio de poder orçamentário, as quais podem servir de parâmetro à análise judicial na verificação da prova da escassez de recursos. Esses desvios de poder orçamentário

117 Da dicção do artigo $9^{\circ}$ da LRF (BRASIL, 2000), a suspensão da execução das despesas por ato do Poder Executivo (contingenciamento) somente é autorizada no caso de frustração do fluxo de receitas, permitindo o contingenciamento da despesa de forma a adequar o resultado orçamentário ao cumprimento das metas fiscais. 
podem ocorrer: a) na elaboração da lei; b) na execução orçamentária; c) nas receitas pela sua superestimação ou sua subestimação intencional; d) na constituição de dívidas para fins diversos do previsto em lei sem a observância de vedações e do procedimento; e) no contingenciamento de despesas visando à obtenção dos créditos anulados para abertura de créditos adicionais e aplicação em outros fins não previstos na LOA; f) na anulação de valores empenhados com deliberada intenção de obter créditos adicionais; g) na instituição excessiva de fundos; h) no emprego de créditos vinculados i) na desvirtuação dos fins de aplicação de recursos provenientes de transferência; i) na renúncia de receitas; 1) por omissão. Para o autor, qualquer desvio de poder constitui um vício objetivo e o ponto de partida da sua averiguação reside na comparação entre o fim da norma e a divergência do fim atingido pelo ato praticado, prescindindo de uma avaliação da motivação interna do agente.

Venâncio (2016, p. 117-118) também relaciona o que denominou de "figuras sintomáticas" criadas pela doutrina e jurisprudência italianas e que são acatadas pelo ordenamento jurídico e pela doutrina de diversos países, como prova indireta do vício de desvio de poder. Dentre os mais pertinentes para o tema abordado, relacionamos: a) declaração falsa e errônea na avaliação ("travisamento") dos fatos ${ }^{118}$; b) contradição ou ilogicidade na motivação ${ }^{119}$; c) motivação inexistente ou insuficiente ${ }^{120}$; d) motivação excessiva $^{121}$; e) inobservância de norma interna ${ }^{122}$; f) precipitação na edição do ato $^{123}$; g)

118 “Ocorre quando se emite um ato que considera um fato existente ou inexistente ou dá ao fato um significado errôneo ou irracional, dos quais são exemplos, pagamentos de notas fiscais 'frias' de produtos ou serviços, não entregues e não prestados; nomeação sabidamente de pessoa morta para ocupar cargo público, com pagamento mensal regular, em ambos com fim de desviar recursos públicos” (VENÂNCIO, 2016, p.117 ).

119 "Verifica-se quando a motivação do ato for ilógica ou contraditória em partes, mormente nos 'considerandos' ou quando o preâmbulo é contraditório à justificação, ou quando é contrária ao dispositivo final, que se denomina de 'decisão suicida', por exemplo, quando um relatório final de uma comissão de disciplina em processo administrativo disciplinar reconhece a culpa, mas ao final opina pela absolvição para favorecer o servidor acusado, ou vice e versa, quando motiva pela inocência e conclui pela condenação para perseguir o acusado" (VENÂNCIO, 2016, p. 117).

120 Configura-se “quando o ato é praticado sem qualquer motivação ou com ínfima motivação, no estilo 'defiro', 'indefiro por falta de amparo legal', 'fi-lo porque qui-lo"” (VENÂNCIO, 2016, p. 117).

121 Ocorre "em casos de textos retóricos intermináveis, com transcrição de doutrina e jurisprudência, sem abordar os fatos e sem concatenar fato e direito num discurso retórico, com finalidade de impressionar pela suposta erudição ou como mecanismo de desencorajar a leitura, o que se dá também em projetos de engenharia que se perdem em fotos, estatísticas, e números sem fins para acobertar o direcionamento da licitação, com questões altamente técnicas, mas irrelevantes, em manifesto desvio de poder" (VENÂNCIO, 2016, p. 117).

122 Ocorre "quando a Administração Pública difere da própria diretriz que tenha comunicado de forma geral ou de uma circular interna da autoridade superior, que deve valer de modo igual a todos, não podendo ser derrogada para atender caso particular" (VENÂNCIO, 2016, p. 118).

123 Figura sintomática que se caracteriza "no apressamento na emissão de atos, tanto para favorecimento como para perseguição de terceiro". Situações extremamente comuns no início de mandatos eletivos com instauração de processos licitatórios, não raro na modalidade convite para pagar dívidas de campanha, ou, após as eleições e antes do término do mandato, para procurar deixar a documentação em dia, ou para desvio 
excesso de publicidade da Administração direta e indireta ${ }^{124}$ e h) falta de predeterminação dos critérios na atribuição de benefícios e na atividade de fomento econômico ou social ${ }^{125}$.

A existência de contas rejeitadas pelo respectivo Tribunal de Contas e de recomendações não atendidas, também podem indicar a contumácia nas irregularidades orçamentárias. Essas "figuras sintomáticas" constituem no âmbito processual espécies de indícios $^{126}$ e não podem ser tomadas isoladamente, de maneira superficial, como meio de prova idôneo capaz de comprovar o desvio de poder como vício de ilegalidade. Assim, terão seu peso avaliado no caso concreto e somente ter-se-á como provado o desvio orçamentário no caso de existência de, ao menos, um indício necessário ou de vários indícios homogêneos contingentes e convergentes $^{127}$. Ou seja, se houver indícios de que a insuficiência de recursos se deu em razão de desvios orçamentários praticados tanto no âmbito da previsão da receita ou da fixação das despesas, ou por contingenciamentos imotivados ou de motivação questionável, a confiabilidade epistêmica da premissa empírica que sustenta o princípio da reserva do possível fica comprometida.

No próximo capítulo, será abordado o tratamento do princípio da reserva do possível na ponderação, nos moldes da teoria de Alexy.

de dinheiro público (VENÂNCIO, 2016, p. 118).

124 Consiste na "propaganda do governo de plantão e também das empresas estatais, mesmo quando esta mantém o 'monopólio da atividade' em propagandas sem qualquer finalidade social ou de interesse público em horários nobres em todas as emissoras de televisão, jornais revistas, rede de comunicação informatizada, com gastos demasiados de dinheiro público" (VENÂNCIO, 2016, p. 118).

${ }^{125}$ Ocorre "quando a Administração por atos ampliativos ou de incentivo à atividade particular, seja por subvenções, empréstimos subsidiários ou concessão de benesses sem predeterminar os critérios gerais e sem parâmetros e critérios básicos para conceder benefícios, deixando com ampla liberdade para quem quer favorecer" (VENÂNCIO, 2016, p. 118).

126 Guilherme Marinoni e Sérgio Cruz afirmam que: "As presunções não se confundem com os indícios, uma vez que as primeiras devem ser valoradas para a formação do juízo de mérito, ao passo que o indício e a prova indiciária devem ser valorados para a elaboração da presunção" (MARINONI; ARENHART, 2009, p. 135).

127 Relembra a classificação dos indícios de Fabiana Del Padre Tomé que, do ponto de vista do valor probatório, são de duas espécies: “(I) necessários, que revelam com elevado grau de probabilidade determinada situação; e (II) contingentes, que indicam de forma mais ou menos provável certo acontecimento. Quanto ao grau de probabilidade, destaca: (I) indícios homogêneos, de conteúdos convergentes, todos conduzindo a um mesmo resultado; e (II) indícios heterogêneos, indicativos de fatos diversos, a demandar do julgador apreciação conjunta, pesando todos os fatores para construir sua convicção. Os indícios necessários e homogêneos integram um conjunto harmônico, que conduz univocamente a determinada conclusão, configuram os indícios veementes e axiologicamente fortes. Os indícios contingentes e heterogêneos compõem um grupo de elementos contraditórios entre si, quebrando a univocidade, com valor axiológico fraco, denominados indícios insuficientes. Indício é prova e esta, por sua vez, é indício de um fato. A força probatória de qualquer indício deve ser avaliada no caso concreto. Havendo um único indício necessário ou vários indícios contingentes e convergentes, ter-se-á provado o fato" (TOMÉ apud VENANCIO, 2016, p. 119-120). 


\section{A TEORIA dOS PRINCÍPIOS DE ROBERT ALEXY E A ANÁliSE DA RESERVA DO POSSÍVEL NA PONDERAÇÃO: UMA PROPOSTA DE CRITÉRIOS PARA ANÁLISE DA CONFIABILIDADE EPISTÊMICA DE PREMISSAS EMPÍRICAS E NORMATIVAS DO PRINCÍPIO}

Tanto os direitos fundamentais quanto o orçamento público têm seus vetores normativos extraídos de normas constitucionais, entre as quais não há como se estabelecer, $a$ priori, uma relação de primazia. Embora seja defensável a ideia regulativa de que a priorização do compromisso constitucional de concretização dos direitos fundamentais possa atribuir maior legitimidade às opções políticas que orientam o orçamento público ${ }^{128}$, esse aspecto não é suficiente para se determinar, de forma abstrata, qual norma deverá prevalecer em todos os conflitos apresentados à solução do Poder Judiciário. Isso porque há uma gama de situações fáticas e de arranjos orçamentários possíveis, que podem ser estabelecidos para a efetivação das prestações materiais devidas pelo Estado ao cidadão. Por esta razão, o exame da proporcionalidade será necessário quando o princípio da reserva do possível for invocado nas ações judiciais ${ }^{129}$ e estiver em colisão com um princípio que veicula a proteção de um direito fundamental. Como visto, a ponderação é uma técnica adequada para se extrair a máxima efetividade/efetivação possível dos direitos fundamentais e outros valores veiculados através de normas principiológicas que se encontram em situação de colisão no caso concreto.

É inquestionável que as principais decisões sobre as escolhas financeiras estatais cabem precipuamente ao Legislativo em diálogo com o Executivo. Ambos detêm a prerrogativa de modificar as definições globais das despesas e ampliar a receita. Portanto, algumas zonas de decisão seriam impenetráveis ao Poder Judiciário. Por isso mesmo, os poderes políticos possuem as maiores responsabilidades na aferição sistêmica das possibilidades financeiras e definição de prioridades, cabendo ao Judiciário considerar esse espaço de deliberação. Por outro lado, cabe também ao Poder Judiciário assegurar a preservação do conteúdo dos direitos que não se encontram na esfera de disposição das maiorias (MENDONÇA, 2010, p. 192).

${ }^{128}$ Segundo Ricardo Lobo Torres (2000, p. 166): “Os direitos fundamentais têm uma relação profunda e essencial com o orçamento público. Dependem, para a sua integridade e defesa, da saúde e do equilíbrio da atividade financeira do Estado, ao mesmo tempo em que lhe fornecem o fundamento da legalidade e da legitimidade".

129 Para Eduardo Cambi (2016, p. 283), cabe ao Judiciário verificar, no caso concreto, se o conteúdo de um direito fundamental deve ser restringido em face da prevalência de outro princípio que apresente peso concreto maior, cuja restrição somente pode se dar por razões partilháveis por qualquer pessoa racional e não somente por uma concepção dos titulares do poder. 
Mendonça (2010, p. 164) afirma enfaticamente que "é preciso desconstruir o mito de que os juízes não devem intervir nas decisões sobre a alocação dos recursos públicos". A assertiva é correta. Primeiro, porque a jurisdição é indispensável no Estado Democrático de Direito. Muito embora o Judiciário não tenha a função precípua do controle externo e de redistribuição dos bens na sociedade por meio das escolhas orçamentárias, no Estado Democrático de Direito, o direito fundamental de acesso à justiça assenta-se na possibilidade de o indivíduo submeter à apreciação do Poder Judiciário qualquer violação ou ameaça de violação a seus direitos (BRASIL, 1988, CF, art. 5, XXXV). A inafastabilidade da submissão à apreciação do Poder Judiciário das lesões e ameaças de lesões a direitos traz para os órgãos jurisdicionais a possibilidade de exercer uma espécie de controle jurídico-financeiro do orçamento público (SCAFF, 2018, p. 464).

Nestes casos, o Judiciário atua como garantidor da efetivação das normas constitucionais, inclusive, do direito do cidadão-contribuinte, ao zelar pela legalidade, moralidade, razoabilidade, proporcionalidade e eficiência dos meios empregados pelas opções públicas que são concretizadas nas leis orçamentárias e nos respectivos atos administrativos. Ademais, esse poder possui uma função contramajoritária (CAMBI, 2010, p. 282), servindo de garantia dos direitos fundamentais e da própria democracia contra decisões da maioria violadoras de direitos das minorias. No entanto, como adverte Cambi, a atuação judicial é subsidiária e limitada. Em suas palavras:

\footnotetext{
Todavia, tal intervenção não pode ser irrestrita nem irresponsável, devendo ocorrer somente quando há um dever legal ou constitucional violado. Trata-se, pois, de intervenção derivada ou subsidiária. Logo, a liberdade do juiz não é absoluta, estando limitada pelas potencialidades da interpretação sistemática da Constituição ou das leis e a solução da situação fática emoldurada no caso concreto (CAMBI, 2016, p. 360-361).
}

Ressalta-se que, pelo princípio da inércia, o Judiciário não pode adentrar na análise da constitucionalidade dos atos praticados pelos demais poderes constituídos a não ser que devidamente provocado para tanto. Mas quando esta provocação ocorre, segundo Olsen (2006, p. 310), é porque se verificou "uma pretensão resistida", ou seja, no caso dos direitos fundamentais a prestações, verificou-se uma potencial omissão violadora do Estado em cumprir tarefa prevista na Constituição Federal. Nesta condição, o Judiciário é convocado a fazer valer a norma constitucional de forma a aferir se a atuação política dos demais poderes deixou de atender pretensões jusfundamentais, de modo garantir que a não satisfação do 
direito fundamental não implique "a exclusão social de seu titular" (OLSEN, 2006, p. 310).

Nessas ações, ao lado do princípio da reserva do possível, uma das objeções que tem sido costumeiramente invocada para afastar as decisões alocativas da sindicabilidade judicial é a violação do princípio da separação dos poderes. Contudo, como destaca Mendonça (2010, p. 164), o Judiciário já atua em questões que afetam as finanças públicas, de forma cotidiana, como nas demandas tributárias ${ }^{130}$ que atingem a receita e, indiretamente, alteram os limites dos gastos públicos. Outro momento de intervenção nas finanças públicas ocorre quando o Judiciário é chamado a julgar reparações civis do Estado por conta de danos provocados pelas condutas dos agentes públicos e nem por isso uma eventual decisão condenatória é reconhecida como ilegítima por intervir na esfera política (MENDONÇA, 2010, p. 164).

A possibilidade de se valer de uma prestação jurisdicional para análise de lesão ou ameaça de lesão a direitos é decorrência do Estado de Direito que também vincula todos os poderes constituídos e agentes públicos à observância da ordem jurídica constitucional. Mendonça (2010, p. 166) ainda destaca que o argumento da interferência indevida do Poder Judiciário na competência dos Poderes Legislativo e Executivo é mais utilizado quando estão em jogo a efetivação de prestações sociais, ao contrário do que ocorre nas ações tributárias e de reparação de danos que também atingem a seara das finanças públicas. Essa postura revelaria o caráter ideológico que está velado e que impinge somente na efetivação dos direitos prestacionais a "percepção difusa de que se estaria diante de uma decisão governamental exclusivamente política ou mesmo e uma 'liberalidade estatal', a ser concedida na extensão da generosidade dos agentes eleitos" (MENDONÇA, 2010, p. 166).

Pode-se afirmar que os Poderes Legislativo, Executivo e Judiciário constituem braços de um poder uno, cujas atividades são orientadas pelos objetivos impostos ao Estado pela Constituição, principalmente, no tocante à garantia dos direitos fundamentais. Em uma concepção mais compatível com as funções estatais de concretização de direitos fundamentais por meio de ações positivas, a atuação desses poderes deve se dar de "forma coordenada e não antagônica" (MENDONÇA, 2010, p. 191).

Não há como deixar de reconhecer que, em nosso ordenamento jurídico, está atribuída ao Poder Judiciário a competência de apreciação da circunstância em que um ato discricionário foi praticado - se nos limites da competência e em conformidade com os

130 MENDONÇA (2010, p. 164) destaca que "não se sustenta seriamente que os juízes estejam proibidos ou devam ser parcimoniosos no controle da tributação, sob o argumento de que essa seria uma forma inválida de intromissão na seara política", apesar de sem receita não haver verba pública e sem verba não haver gasto. 
parâmetros constitucionais -, mesmo nas demandas individuais. Obviamente, desde que o Judiciário seja devidamente provocado para essa apreciação. Diferentemente de outros países, em que a apreciação dos atos administrativos não se dá perante o Poder Judiciário, mas em Tribunais Administrativos, não existe no direito brasileiro norma constitucional que afaste expressamente as decisões orçamentárias de controle jurisdicional, mesmo porque a maioria das sanções previstas no caso de descumprimento das normas orçamentárias depende de apreciação judicial para ser aplicada.

Contudo, a fim de inibir decisões casuístas que desequilibram a atuação dos poderes constituídos e comprometem a segurança jurídica, a atuação jurisdicional deve ser orientada pela capacidade de justificação racional de suas decisões ${ }^{131}$. Principalmente quando incidir sobre escolhas legislativas referentes ao orçamento e às políticas públicas essa postura jurisdicional pode constituir "um mecanismo propulsor de melhores deliberações, inclusive para que o regime democrático não seja apenas uma forma de separar maiorias de minorias, mas também de discernir entre os melhores argumentos" (CAMBI, 2016, p. 275).

\subsection{RESERVA DO POSSÍVEL E A PONDERAÇÃO EPISTÊMICA}

O ordenamento jurídico pátrio impõe a exigência de que o juiz justifique, racionalmente, o seu convencimento quando interpreta as leis e no momento em que valora as provas, evitando fundamentos genéricos (BRASIL, 2002, art. 489, §1. ${ }^{\circ}$ ). A lei processual civil vigente determina, ainda, que "no caso de colisão entre normas, o juiz deve justificar o objeto e os critérios gerais da ponderação efetuada, enunciando as razões que autorizam a interferência da norma afastada e as premissas fáticas que fundamentam a conclusão" (BRASIL, 2002, art. 489, §2º).

Toledo (2017, p. 39) ressalta que "conferir objetividade aos julgamentos é não apenas proporcionar sua controlabilidade, mas promover a justiça das decisões tomadas”. E prossegue afirmando que: "Uma vez que objetividade controlável é a antítese de subjetividade arbitrária, indubitavelmente, uma decisão será tão mais justa quanto mais critérios objetivos tiver para a justificação das escolhas feitas" (TOLEDO, 2017, p. 39).

\footnotetext{
131 Nesse sentido, é a posição de Olsen (2006, p. 364): "Por outro aspecto, a reserva do possível, se devidamente analisada em cada caso concreto, em respeito à especial hierarquia das normas de direitos fundamentais, pode contribuir para uma maior racionalidade das decisões judiciais, na medida em que exige do intérprete a observância das circunstâncias da realidade que o cerca (a chamada 'reserva de consistência'), de modo a evitar sentenças de impossível execução, que comprometem a dignidade do Direito".
} 
Embora a norma processual não indique especificamente a forma da ponderação que o juiz pode efetuar, cumpre assinalar que seu comando encontra consonância com a máxima da proporcionalidade nos moldes da teoria de Robert Alexy. A proposta do jusfilósofo alemão traz a possibilidade de um maior controle da discricionariedade judicial, por meio da racionalidade no uso da ponderação, uma vez que discrimina, passo a passo, o raciocínio a ser adotado pelo intérprete da norma. A adoção desse procedimento possibilita um melhor controle dos fundamentos das decisões judiciais. A ponderação, neste caso, é uma das etapas que compõe a técnica de decisão utilizada no caso de colisão de princípios jurídicos, denominada máxima da proporcionalidade.

$\mathrm{O}$ processo de cognição ${ }^{132}$ judicial ínsito à ponderação que envolva o princípio da reserva do possível, ao ser informado por parâmetros objetivos, atende ao dever de motivação racional das decisões exigido pelo Estado Democrático de Direito e em norma constitucional (BRASIL, 1988, art. 93, IX), afastando decisões baseadas na íntima convicção do magistrado. Cambi (2016, p. 432) adverte que o magistrado deve preocupar-se com a motivação tanto das questões jurídicas quanto das questões fáticas, devendo ser combatido o que denominou de "fenômeno da motivação fictícia","

Ao tratar do pensamento de Alexy, Camargo (2018, p. 74) afirma:

\begin{abstract}
A ênfase do posfácio recai sobre a tentativa de provar que o discurso jurídico foge à irracionalidade, à subjetividade e ao relativismo, sendo passível de controle. "As suposições, que estão na base das sentenças sobre a intensidade da intervenção e do grau de importância não são arbitrárias", diz-nos Alexy, "porque são argumentos que expressam publicamente reflexão". Dessa forma, o juiz assume claramente o peso valorativo dos argumentos que organizam o seu discurso e que servem de justificativa para a decisão.
\end{abstract}

Ao contrário de alguns autores que atribuem à proporcionalidade a natureza de princípio, Alexy demonstra, de forma analítica, que a proporcionalidade é uma espécie de

132 A cognição é prevalentemente um ato de inteligência, consistente em considerar, analisar e valorar as alegações e as provas produzidas pelas partes, vale dizer, as questões de fato e as de direito que são deduzidas no processo e cujo resultado é o alicerce, o fundamento do judicium do julgamento do objeto litigioso do processo (WATANABE, 1987, p. 41).

133 O autor esclarece: "com o intuito de não prejudicar a autoridade das decisões, confecciona-se um discurso que não contém nenhuma justificação racional ou, simplesmente, omite-se a justificação da decisão sobre as questões fáticas, ao tentar suprir esta omissão com uma abundante motivação das questões jurídicas. Isso, aliás, é muito comum em decisões que se valem de expressões que, sem qualquer nexo com o caso concreto, nada explicam (v.g., 'prova para condenar tem que ser robusta'; 'a palavra da vítima assume especial relevância nos crimes sexuais'; 'a boa-fé do litigante sempre se presume’ etc.). [...] Combater o arbítrio judicial é evitar os discursos jurídicos assentados na intime conviction, a qual se manifesta tanto nas decisões sem qualquer motivação como naquelas em que a motivação é fictícia” (CAMBI, 2016, p. 432). 
metarregra (ou máxima), que é demandada pela exigência de racionalidade no tratamento das colisões entre os princípios jurídicos. O jusfilósofo esclarece que a aplicação da técnica da proporcionalidade é efetuada a partir da análise sucessiva de três submáximas (ou máximas parciais): a adequação, a necessidade e a proporcionalidade em sentido estrito (ALEXY, 2018, p. 5).

Um dos argumentos para excluir o tratamento da proporcionalidade como um princípio jurídico é que suas máximas parciais devem sempre ser satisfeitas de forma total ("tudo ou nada"), e o não atendimento a qualquer uma delas implicaria o reconhecimento de uma intervenção não autorizada em um princípio constitucional. A análise dessas máximas parciais deve ser feita sequencialmente. Somente se prossegue à análise da etapa seguinte, caso a máxima parcial anterior seja atendida. Primeiramente, são avaliadas as máximas parciais da adequação e da necessidade, as quais se referem à otimização das possibilidades fáticas com o objetivo de afastar os “custos evitáveis" (ALEXY, 2018, p. 5). Quando houver colisão de princípios, a ponderação - que é objeto da máxima parcial da proporcionalidade em sentido estrito - torna-se necessária. Nesta fase é feita a análise da otimização em relação às possibilidades jurídicas e ela constitui a etapa final da máxima da proporcionalidade (ALEXY, 2018, p. 5).

Alexy explicou como se realiza uma ponderação mediante o que denominou de lei da ponderação, expressa da seguinte forma: "Quanto maior o grau de não cumprimento ou de restrição de um princípio, maior deve ser a importância do cumprimento do outro" (ALEXY, 2018, p. 6). A descrição mais precisa da estrutura da ponderação é dada pela fórmula do peso que é representada pela equação abaixo ${ }^{134}$ :

$$
W_{i j}=\frac{I_{i} \cdot W_{i} \cdot R_{i}}{I_{j} \cdot W_{j} \cdot R_{j}}
$$

Em seguida, aprimorando seu raciocínio, introduz variáveis epistêmicas na ponderação e enuncia o que chamou de lei da ponderação epistêmica, segundo a qual "quanto mais pesada for uma interferência em um direito fundamental, maior deve ser a certeza das premissas que a justificam" (ALEXY, 2018, p. 7).

\footnotetext{
$134 \mathrm{Na}$ fórmula do peso Alexy (2018, p. 6) utiliza as variáveis peso (W), intensidade (I) e certeza ou confiabilidade (R), que em alemão são representadas, respectivamente, pelas vogais G (Gewight), I (Intensität) e S (Sichernheit), razão pela qual pode-se encontrar a fórmula do peso representada por outros autores com estas variáveis.
} 
Em 2014, ressaltando a importância sistemática da distinção entre discricionariedade epistêmica empírica e discricionariedade epistêmica normativa, Alexy complementou a fórmula do peso. O jusfilósofo alemão afirmou que, quando se trata de premissas justificadoras da interferência, deve-se abranger tanto premissas normativas quanto premissas empíricas, o que foi traduzido pelo que denominou de "equação da certeza" cuja fórmula é assim representada: $\mathrm{R}=\mathrm{R}^{\mathrm{n}} \times \mathrm{R}^{\mathrm{e}}$ (ALEXY, 2018, p. 8). $\mathrm{O}$ autor chegou, então, ao que denominou de "fórmula do peso completa refinada", representada conforme abaixo:

$$
W_{i j}=\frac{I_{i} \cdot W_{i} \cdot R_{i}^{e} \cdot R_{i}^{n}}{I_{j} \cdot W_{j} \cdot R_{j}^{e} \cdot R_{j}^{n_{j}}}
$$

Para uma melhor compreensão da fórmula do peso refinada, Alexy (2018, p. 6) esclarece que a variável $\mathrm{W}_{\mathrm{ij}}$ representa o peso concreto do princípio $\mathrm{P}_{\mathrm{i}}$ em relação ao princípio colidente $\left(\mathrm{P}_{\mathrm{j}}\right)$ que é o quociente dos fatores em cada lado da ponderação. $\mathrm{I}_{\mathrm{i}}$ refere-se à intensidade da interferência em $P_{i}$ (caso $P_{j}$ seja atendido) e $I_{j}$ representa a importância do cumprimento do princípio colidente ou a intensidade da interferência em $\mathrm{P}_{\mathrm{j}}$ (caso $\mathrm{P}_{\mathrm{i}}$ seja atendido). $\mathrm{W}_{\mathrm{i}}$ e $\mathrm{W}_{\mathrm{j}}$ representam os pesos abstratos dos princípios em colisão. Alexy (2018, p. 6) esclarece que as variáveis $I_{i}$ e $I_{j}$, bem como $W_{i}$ e $W_{j}$, referem-se "à dimensão material da ponderação". Por sua vez, $\mathrm{R}_{\mathrm{i}}^{\mathrm{n}}, \mathrm{R}_{\mathrm{i}}^{\mathrm{e}}$ e $\mathrm{R}_{\mathrm{j}}^{\mathrm{n}}$ e $\mathrm{R}_{\mathrm{j}}^{\mathrm{e}}$ referem-se à certeza das suposições empíricas e normativas de cada princípio e se inserem na dimensão epistêmica da ponderação. Essas premissas justificam a interferência no princípio colidente. $\mathrm{Na}$ análise da confiabilidade epistêmica das premissas empíricas e normativas, podem ser atribuídas as seguintes gradações: não evidentemente falso; plausivel e confiável ou certo ${ }^{135}$. O grau em que a confiabilidade epistêmica é mais fraca é definido como "não evidentemente falso" e o grau mais forte é definido como "certo" ou "confiável"136.

135 Esses níveis correspondem a valores de confiabilidade que pode ser substituídos na fórmula do peso da seguinte forma: $2^{-2} ; 2^{-1}$ e $2^{0}$, sendo que o maior valor de confiança (confiável ou certo) corresponde a $2^{0,}$ ou seja, ao valor 1. Esse valor é obtido pelo preenchimento de todos os parâmetros para cada premissa. Cada parâmetro não preenchido diminui no expoente o valor (-1). Assim, o preenchimento de somente 2 parâmetros (para cada premissa) corresponde ao valor de $2^{-1}$ e o preenchimento de somente um parâmetro corresponde a $2^{-2}$. Uma qualidade epistêmica baixa pode reduzir os valores materiais da equação (ou seja I x W). Ou seja, um valor menor do que 1, atribuído às premissas empíricas e normativas do princípio da reserva do possível poderá acarretar a prevalência do direito fundamental, se os valores atribuídos a $\mathrm{I}_{\mathrm{i}} \cdot \mathrm{W}_{\mathrm{i}}$ e $\mathrm{I}_{\mathrm{j}} \cdot \mathrm{W}_{\mathrm{j}}$ forem iguais. O menor valor a ser obtido é $2^{-4}$, ou $1 / 16$ (isso se dá, quando $R e=2^{-2}$ e $R n=2^{-2}$ ). (ALEXY, 2018, p. 9)

136 Para melhor utilização da fórmula acima, Alexy sugeriu uma gradação triádica da confiabilidade das premissas, à qual podem ser acrescentadas outras gradações, caso seja necessário. 
Alexy $(2018$, p. 7) explica que a certeza ou confiabilidade não é um fator ôntico, ou seja, que se refere a coisas (interferência e pesos abstratos), mas ao conhecimento das coisas. Por isso se trata de um fator epistêmico. Esse raciocínio demonstra dois tipos de dúvidas ou incertezas que podem surgir na ponderação de princípios. Camargo $(2018$, p. 79) afirma que o primeiro tipo de dúvida refere-se a qual peso abstrato se pode atribuir aos princípios (e com isso identificar qual a norma deve ser aplicada). O segundo, a qual grau de credibilidade se pode conferir às informações capazes de demonstrar "as consequências da medida e permitir a avaliação, a partir daí, do verdadeiro grau de interferência (intensidade) em um direito fundamental" (CAMARGO, 2018, p. 79-80).

Apenas a análise dos elementos integrantes da norma não é suficiente para a correta utilização da ponderação, sendo igualmente necessária a consideração das premissas empíricas (relativas às condições fáticas do caso concreto), principalmente quando há dúvidas quanto aos meios adequados e necessários avaliados nas duas primeiras etapas da máxima da proporcionalidade ${ }^{137}$. É certo que a importância do cumprimento de um princípio $\left(\mathrm{I}_{\mathrm{i}}\right)$ e a intensidade da interferência que seu cumprimento acarreta sobre o princípio colidente $\left(\mathrm{I}_{\mathrm{j}}\right)$ podem ser melhor aferidas quando se têm como base premissas empíricas e normativas cuja verdade esteja assegurada em nível confiável.

Premissas empíricas relacionam-se ao conhecimento de fatos relevantes e necessários para se estabelecer a intensidade da interferência no direito fundamental e a importância de satisfação do princípio colidente, no caso, o princípio da reserva do possível. Um problema que se coloca é que, se for permitido fundamentar a interferência em direitos fundamentais com base em premissas empíricas incertas relativas aos princípios colidentes, então se torna possível a recusa da proteção aos direitos fundamentais com base em suposições falsas. Consequentemente, possibilitar-se-ia a indevida violação de direitos fundamentais. Por tal razão, o jusfilósofo alemão afirma que os direitos fundamentais exigem não somente uma otimização material, mas também uma otimização epistêmica e na medida em que a verdade das premissas está assegurada, a realização dos direitos fundamentais é aumentada (ALEXY, 2018, p. 17).

\footnotetext{
137 Alexy (2018, p. 16) destaca que "a incerteza empírica pode ser um problema nos três estágios do exame da proporcionalidade". Isso porque, embora a confiabilidade epistêmica esteja inserida na etapa da ponderação, a análise das circunstâncias fáticas e de argumentos empíricos é efetuada no âmbito das máximas parciais da adequação e da necessidade. Assim, a incerteza sobre os meios adequados e a existência de meios menos gravosos também influencia na confiabilidade epistêmica das premissas empíricas relacionadas com o caso concreto em análise.
} 
Em uma ponderação que envolva o princípio da reserva do possível, a escassez de recursos públicos é suposição ou premissa empírica que interfere na realização do direito fundamental assegurado no princípio colidente, na medida em que estabelece um limite às possibilidades fáticas de oferta estatal da prestação material requerida pelo indivíduo, titular do direito subjetivo pleiteado. O nível de escassez dos recursos públicos atua como parâmetro para se avaliar tanto a razoabilidade da pretensão quanto o grau de interferência ou afetação do princípio colidente, bem como a importância em se satisfazer o princípio da reserva do possível. Quanto menos recursos à disposição para a efetivação dos direitos fundamentais, mais dramáticas serão as disputas orçamentárias para a concretização desses direitos. Em um contexto de escassez econômica ou financeira, a satisfação de uma pretensão individual pode significar, ainda, a interferência em outro(s) princípio(s) de direito fundamental, o que aumenta a exigibilidade de alto grau de razoabilidade da pretensão do autor em face de alocações orçamentárias também razoáveis. A escassez de recursos, portanto, o fato empírico mais relevante a ser provado pelo Poder Público, quando se trata da negativa de satisfação de um direito fundamental com base no princípio da reserva do possível.

Na medida em que a escassez de recursos constitui a premissa empírica subjacente ao princípio da reserva do possível, ela passa a constituir um fato a ser provado pela parte que alegou. Sua existência ou extensão não podem ser presumidas, por não haver norma jurídica que autorize essa presunção. Na comprovação das premissas empíricas que sustentam razões para interferência em um princípio de direito fundamental, uma série de procedimentos podem ser usados, como métodos das ciências empíricas, máximas de presunção racional e regras de distribuição do ônus de prova em um processo (MOTA; PEREIRA, 2012, p. 29).

A certeza do conhecimento relativo às premissas empíricas é decisiva para atribuir maior ou menor força tanto às razões que justificam a intervenção no direito fundamental ou a importância de satisfação do princípio da reserva do possível. Quando a escassez de recursos públicos para atender ao direito fundamental - ou o impacto que o atendimento da prestação teria para outros direitos igualmente relevantes - não for devidamente comprovada, podem surgir dúvidas quanto à sua existência, sua extensão ou sua insuperabilidade. Essa dúvida poderá comprometer a correção do resultado da ponderação, porque tem relevância para a correta apuração do grau de interferência no princípio de direito fundamental colidente e do grau de importância de satisfação do princípio da reserva do possível. Alexy afirma que "quanto mais pesada for a intervenção em um direito fundamental, maior terá que ser a certeza das premissas nas quais essa intervenção se baseia" (ALEXY, 2015, p. 618). Isso 
porque, conforme esclarece Alexy, "uma qualidade epistêmica baixa destrói quase completamente o poder até mesmo de razões materialmente mais fortes para a interferência em direitos fundamentais" (ALEXY, 2018, p. 9). Portanto, diferentes intensidades de intervenções em um princípio colidente com o princípio da reserva do possível, vão exigir diferentes graus de certeza das premissas em que se fundamentam tais intervenções.

Desse modo, pode-se afirmar que a confiabilidade epistêmica também é uma exigência da ideia regulativa da pretensão de correção ${ }^{138}$ que é levantada pelo próprio Direito e orienta a fundamentação do discurso jurídico, sob o ponto de vista formal e material.

Assim, na ponderação, é importante considerar não só a confiabilidade do conhecimento dos fatos empíricos relevantes, a partir da cognição das provas trazidas aos autos. É necessário também aferir-se a confiabilidade do conhecimento daquilo que a ordem jurídica determina como o mais relevante e que justifica a intervenção em um princípio de direito fundamental. A certeza epistêmica das proposições normativas refere-se, portanto, à confiabilidade do conhecimento daquilo que, na ordem jurídica, justifica a intervenção no princípio de direito fundamental.

Não obstante, nem sempre se pode ter a plena certeza sobre o que essa ordem jurídica determina, abrindo-se um espaço de incerteza epistêmica normativa. A inflação normativa em nosso sistema jurídico, bem como a presença de conceitos jurídicos abertos e indeterminados podem criar dúvidas quanto à confiabilidade das proposições normativas que autorizam a intervenção em um direito fundamental. Esses fatores podem atingir a certeza sobre qual a forma correta para ponderar os princípios em jogo, sobre qual peso deve ser atribuído a cada princípio ou qual justificativa para a intervenção (CAMARGO, 2018, p. 80). Assevera-se, pois, que essa valoração pelo Poder Judiciário deve ser feita prioritariamente por critérios jurídicos e não políticos, como o faz o legislador.

Em geral, a justificação normativa ocorre quando se demonstra que determinada norma atende aos critérios de validade da ordem jurídica (MOTA; PEREIRA, 2012, p. 29), o

${ }^{138}$ Cláudia Toledo (2021, p. 3), ao analisar a evolução do pensamento de Robert Alexy, destaca que o jusfilósofo inicialmente expôs a ideia de pretensão de correção em sua renomada obra Teoria da Argumentação Jurídica. Esse conceito foi "progressivamente construído, enriquecido e aperfeiçoado em diferentes textos desde a década de 1970". Em apertada síntese, a autora expõe que essa "trajetória pode então ser descrita com a apresentação da pretensão de correção (i) do ponto de vista formal, como pretensão de validade do discurso prático, ideia regulativa satisfeita mediante a justificação argumentativa dos enunciados normativos afirmados; (ii) do ponto de vista material, como pretensão de justiça, que, não obstante tenha conteúdo moral (correção moral ou correção de primeira ordem, própria do discurso prático geral), necessariamente integra a correção jurídica (correção de segunda ordem), sendo necessariamente formulada pelo Direito ou pelo discurso jurídico, segundo a tese do caso especial" (TOLEDO, 2021, p. 20-21, itálicos no original). 
que pode ser extraído tanto das normas gerais criadas pelo legislador, quanto de normas individuais (precedentes) extraídas de decisões judiciais (TRIVISONNO, 2017, p. 99). No caso da confiabilidade epistêmica normativa em relação ao princípio da reserva do possível, há que se aferir se esse princípio está sendo aplicado no âmbito de situações em que juridicamente lhe é permitido incidir. Essa análise pode ser feita tanto a partir da consideração das restrições impostas pelo ordenamento jurídico ao princípio, como já visto no segundo capítulo dessa dissertação, quanto pela importância de satisfação do princípio colidente.

Note-se que, da combinação da lei de ponderação e da lei da ponderação epistêmica, enunciadas por Alexy, pode-se inferir a seguinte formulação: quanto mais pesada for a interferência em um princípio de direito fundamental, maior deve ser a importância do cumprimento do princípio colidente e a confiabilidade das premissas que justificam essa interferência.

Isso significa que, para que o princípio da reserva do possível prevaleça na ponderação, a importância de seu cumprimento e a confiabilidade das premissas que justificam a intervenção no princípio de direito fundamental colidente devem se apresentar em grau mais elevado do que aquele atribuído às mesmas variáveis relativas ao princípio colidente, qual seja, o princípio de direito fundamental. A compreensão dessa estrutura argumentativa é necessária para a correta utilização da ponderação que envolve o princípio da reserva do possível.

A seguir serão explicitados e propostos parâmetros que podem auxiliar na aferição da confiabilidade epistêmica das premissas empíricas e normativas quando se aplicar o princípio da reserva do possível.

\subsection{PARÂMETROS PARA ANÁLISE DA CONFIABILIDADE DA PREMISSA EMPÍRICA DO PRINCÍPIO DA RESERVA DO POSSÍVEL}

Consoante já explicitado, a identificação de parâmetros objetivos que possam ser utilizados nas ações judiciais de modo a orientar com maior correção e racionalidade a ponderação do princípio da reserva do possível é medida necessária para que a aplicação deste princípio não seja banalizada por sua invocação meramente erística. Ao mesmo tempo, contribui para que as decisões possam oferecer uma fundamentação mais objetiva e consistente, em prol da otimização do princípio da segurança jurídica.

Como resultado da pesquisa bibliográfica, procurou-se identificar alguns parâmetros 
para subsidiar a análise do julgador quanto à confiabilidade da premissa empírica subjacente ao princípio da reserva do possível e que determina a intensidade da intervenção no direito fundamental: a escassez ou insuficiência de recursos públicos. Foram identificados três parâmetros principais, a seguir explicitados. Propõe-se que o valor atribuído à confiabilidade epistêmica das premissas empíricas aumente na medida em que os respectivos parâmetros forem atendidos, de forma dar maior força argumentativa à prevalência do princípio da reserva do possível sobre o princípio de direito fundamental colidente.

Outra questão a se destacar é a relevância da análise adequada das premissas empíricas e dos argumentos empíricos pelos juízes e tribunais a quo, uma vez que no âmbito dos recursos especiais e extraordinários somente questões de direito serão apreciadas, não sendo permitido aos tribunais superiores, no âmbito desses recursos, revolverem matéria fática. Essa limitação não se aplica às ações originárias interpostas perante o STF, cuja cognição é ampla, a exemplo da ação direta de inconstitucionalidade (ADI), arguição de descumprimento de preceito fundamental (ADPF) e ação declaratória de constitucionalidade (ADC).

\subsubsection{Existência da prova documental suficiente à comprovação do impacto orçamentário e/ou da inexistência ou da insuficiência do crédito orçamentário para o atendimento da prestação do autor}

A finalidade geral do processo de conhecimento é a obtenção de uma declaração, consistente em conferir-se certeza jurídica à existência ou inexistência do direito afirmado pelo autor na petição inicial. Igualmente, a mesma análise jurídica é feita em relação aos fatos

que podem obstar ao reconhecimento do direito pleiteado. Conforme assevera Camargo (2018, p. 72), "fatos suficientemente comprovados mostram-se determinantes para aquilo que 'deve ser'”. Para prolatar a decisão apta ao alcance desse desiderato é preciso que o juiz examine, valore as alegações e as provas produzidas no processo e fundamente sua decisão, em um procedimento dialógico.

Toda prova possui uma função demonstrativa (cognoscitiva), no sentido de que se destina a demonstrar, a partir de um raciocínio formal, a existência ou inexistência de um fato ou a verdade ou falsidade de uma afirmação sobre esse fato, fornecendo ao julgador elementos para motivar sua decisão. Depreende-se, pois, que o grau de confirmação das premissas fáticas é o resultado de inferências lógicas que decorrem da qualidade e da quantidade do conhecimento produzido pelas provas disponíveis no processo (OLIVEIRA, 
2016, p. 132).

A distribuição do ônus probatório tem, em regra, que observar o disposto no artigo 373 e parágrafos, da Lei n ${ }^{\circ}$ 13.105/2015 (NCPC), o qual estabelece que incumbe ao autor, quanto ao fato constitutivo de seu direito (BRASIL, 2015, art. 373, I ) e ao réu, quanto à existência de fato impeditivo, modificativo ou extintivo do direito do autor (BRASIL, 2015, art. 373, II). Nas ações que demandam uma prestação do poder público para atendimento a um direito fundamental, supostamente violado pela conduta omissiva do ente público, incumbe ao autor demonstrar a existência do direito e a razoabilidade da sua pretensão. Em decorrência, deve demonstrar haver a violação ou a ameaça de violação decorrente da ausência ou da insuficiência de uma prestação estatal específica que seja adequada, necessária e suficiente para efetivação do direito fundamental. Por sua vez, ao ente público que figurar como réu (ou requerido) cabe provar as alegações que trouxer em sua defesa.

Na pesquisa empírica realizada, verificou-se que, de modo geral, o ente público, ao qual se demanda a realização de obrigações de fazer ou pagar, tem utilizado em sua defesa argumentos institucionais (lei, precedentes, dogmática jurídica ou doutrina) e argumentos empíricos ${ }^{139}$. No âmbito das ações em que o poder público é demandado para efetivar prestações positivas de direitos fundamentais, os argumentos institucionais, em geral, giram em torno da negativa de efetivar a prestação requerida pela suposta violação dos princípios da reserva do possível e da separação dos poderes. Além da violação de princípios jurídicos, outros argumentos institucionais são invocados, como a suposta violação de normas constitucionais e das leis orçamentárias, vez que, depois de feitas as escolhas de alocações orçamentárias, não caberia ao Executivo alterá-las sem autorização legislativa, a não ser nos casos autorizados na Lei Orçamentária Anual (LOA) e na Lei de Diretrizes Orçamentárias (LDO). Os argumentos empíricos, por sua vez, relacionam-se à inexistência ou à insuficiência fática dos recursos públicos para a concretização do direito pleiteado, justificando que o atendimento à prestação requerida pelo autor da ação prejudicaria o atendimento a outros direitos e interesses relevantes.

Na medida em que não há norma jurídica que autorize a presunção da escassez dos recursos públicos, ela se qualifica como um fato jurídico a ser provado - com meios de provas idôneos - pela parte que trouxe argumentativamente aos autos a alegação de sua ocorrência. Ao alegar a impossibilidade orçamentária em atender à prestação requerida pelo autor, o

${ }^{139}$ Os conceitos de argumentos institucionais e argumentos empíricos são tomados de acordo com a Teoria da Argumentação Jurídica proposta por Robert Alexy (2017, p. 223-263). 
Poder Público atrai para o Poder Judiciário o dever de efetuar a análise da verdade ou da plausabilidade de sua alegação. Neste caso, não há intervenção indevida do Judiciário, uma vez que provocado pelo próprio ente público que poderia ter alegado outros fatos em sua defesa.

Não é qualquer prova que pode ser admitida no processo. Pelo teor do artigo 369 da Lei $\mathrm{n}^{\mathrm{o}} 13.105 / 15$ (NCPC), as partes têm o direito de empregar todos os meios legais, bem como os moralmente legítimos, ainda que não especificados na norma processual, para provar a verdade dos fatos em que se funda o pedido ou a defesa e influir eficazmente na convicção do juiz. Para ter em eficácia como meio de prova, qualquer documento trazido aos autos não pode apresentar dúvidas sobre sua autenticidade e integridade, ou possuir outros vícios. Caso contrário o documento pode descartado e ter comprometida sua aptidão para influir sobre o juízo sobre as alegações e sobre os fatos aos quais se destinavam provar. Os documentos públicos em geral gozam de presunção de veracidade. A prova da limitação orçamentária, incorporando-se ao processo por meio documental, submete-se às regras acima.

A lei orçamentária é documento, por excelência, apto à demonstração das possibilidades orçamentárias de qualquer ente estatal demandado. Possui natureza de prova documental e é meio necessário para subsidiar a prova da escassez de recursos. Importante ressaltar que, em relação aos meios de prova, não há hierarquia, uma vez que o Código de Processo Civil não adotou o sistema de provas tarifadas. Assim, o juiz tem margem de liberdade para apreciação do elemento de prova e motivadamente estabelecer o seu peso probatório de acordo com o conjunto dos demais elementos trazido aos autos.

A LOA é o documento em que se materializa a distribuição de recursos orçamentários de cada ente da federação. Nela é discriminada a estimativa das receitas e são fixadas as despesas do respectivo exercício financeiro, de acordo com o programa de governo (BRASIL, 1964, Lei n. 4.320 , art. $\left.2^{\circ}\right)^{140}$. Nesta lei orçamentária estarão previstos os créditos orçamentários discriminados por natureza de despesa e que receberão a dotação correspondente. Por sua vez, a execução da programação financeira e o cronograma de desembolso $^{141}$ são fixados por decreto do Poder Executivo. Assim, o detalhamento das despesas que serão executadas, com a especificação de seus elementos, é efetuado nesta fase,

140 "Art. $2^{\circ}$. A Lei do Orçamento conterá a discriminação da receita e despesa de forma a evidenciar a política econômica financeira e o programa de trabalho do Governo, obedecidos os princípios de unidade universalidade e anualidade" (BRASIL, Lei $\left.\mathrm{n}^{\mathrm{0}} 4.320,1964\right)$.

141 "Art. $8^{\circ}$. Até trinta dias após a publicação dos orçamentos, nos termos em que dispuser a lei de diretrizes orçamentárias e observado o disposto na alínea $c$ do inciso I, do art. $4^{\circ}$ o Poder Executivo estabelecerá a programação financeira e o cronograma de execução mensal de desembolso" (BRASIL, 2000, LRF). 
diretamente no sistema de execução orçamentária do Governo Federal, razão pela qual alguns especialistas consideram ser este o "verdadeiro orçamento" (LIMA, 2015).

Tratando-se a execução orçamentária de um processo contínuo e dinâmico pela possibilidade de alteração pelo Poder Público daquilo que foi inicialmente planejado, somente a apresentação da LOA e de seus anexos no processo judicial é insuficiente para a devida apuração da limitação orçamentária, pois esta retrata uma situação estática e inicial do planejamento orçamentário. Assim, para melhor demonstração dessa dinâmica orçamentária, o Poder Público deve se valer de alguns instrumentos previstos pela Lei de Responsabilidade Fiscal (Lei Complementar $n^{\circ}$ 101/2000). Em seu artigo 48, a referida lei determinou a obrigação de disponibilizar alguns instrumentos de transparência da gestão fiscal, dentre eles: a Lei de Diretrizes Orçamentárias (LDO), as prestações de contas e pareceres prévios, o Relatório Resumido da Execução Orçamentária (RRO), o Relatório de Gestão Fiscal (RGF) e as versões simplificadas desses documentos ${ }^{142}$. A esses documentos deverá ser dada ampla divulgação, inclusive em meios eletrônicos de acesso público.

A qualidade e suficiência da prova apresentada será base para aferição do grau de confiabilidade epistêmica da premissa empírica invocada: a escassez de recursos públicos. A juntada aos autos dos documentos acima relacionados permite ao juiz atribuir um grau mínimo - correspondente ao "não evidentemente falso" na escala triádica supramencionada à confiabilidade epistêmica da premissa empírica alegada. Ao mesmo tempo, garante a observância do dever de transparência do governo na gestão dos recursos públicos. Ao contrário, sem a juntada dos documentos orçamentários, restará prejudicado qualquer juízo sobre a confiabilidade da premissa empírica que autorize a atribuição de grau elevado (grave) à importância de satisfação do princípio da reserva do possível e consequente fixação de grau grave de intervenção no princípio de direito fundamental colidente. Neste caso, seria temerária a atribuição de peso grave à importância de sua satisfação sem que se conheça a real situação fática.

Assim, defende-se que é necessário ao ente público apresentar, no mínimo, as leis orçamentárias vigentes e os respectivos relatórios e anexos, a partir dos quais possam ser verificados os valores das alocações, comprovando a inexistência ou insuficiência de dotações nas respectivas rubricas orçamentárias para o atendimento ao direito pleiteado. E, quando se

\footnotetext{
142 “Art. 48. São instrumentos de transparência da gestão fiscal, aos quais será dada ampla divulgação, inclusive em meios eletrônicos de acesso público: os planos, orçamentos e leis de diretrizes orçamentárias; as prestações de contas e o respectivo parecer prévio; o Relatório Resumido da Execução Orçamentária e o Relatório de Gestão Fiscal; e as versões simplificadas desses documentos” (BRASIL, 2000, LRF).
} 
alegar prejuízo a outros direitos ou a outros interesses relevantes, os documentos orçamentários devem ser analisados, preferencialmente, em conjunto com um laudo do impacto orçamentário da prestação pleiteada sobre o orçamento e sobre a afetação dos outros direitos, a ser juntado pela parte a quem couber a prova ${ }^{143}$. Isso porque a boa-fé objetiva no âmbito processual exige uma postura colaborativa das partes para a busca da solução jurídica mais adequada. Assim, a despeito de eventuais deficiências institucionais na detenção de conhecimento empírico e técnico pelo órgão julgador - que pode não contar com o recursos humanos, materiais ou tempo necessários para esquadrinhar os documentos orçamentários, extraindo as informações necessárias para aferir as possibilidades orçamentárias estatais -, nada impede que esclarecimentos sejam fornecidos por quem tem condições de fazê-lo, cabendo à parte reunir dados consistentes que respaldem sua alegação.

Aliás, Carmargo (2018, p. 71) afirma que tem sido prática cada vez mais constante nos tribunais a busca de apoio em argumentos científicos para decidirem com maior segurança. Em suas palavras:

\begin{abstract}
Procura-se, assim, por um lado, na expertise de especialistas, a ampliação do conhecimento sobre os problemas submetidos a julgamento, enquanto, por outro lado, são recebidas informações por aparte de grupos de interesse, sobre fatos, cujo conhecimento proporcionaria às Cortes um melhor e mais adequado esclarecimento da matéria sob julgamento. É o que ocorre nas audiências públicas realizadas pelo Supremo Tribunal Federal brasileiro (CAMARGO, 2018, p. 71-72).
\end{abstract}

Assim, ante a alegação da insuficiência de recursos, cabe ao ente público, que figura como réu, expor de forma compreensível e objetiva as opções de gasto priorizadas e as justificativas para tanto, impedindo-se a invocação do princípio da reserva do possível, de forma genérica, no âmbito de uma escassez de recursos nunca comprovada (MENDONÇA, 2010, p. 189-190). A garantia de um equilíbrio probatório entre as partes impõe aos agentes públicos o dever de que estejam prontos a apresentar informações, esclarecimentos e documentos aos órgãos de controle, prestando conta de sua atividade (VENÂNCIO, 2016, p. 124). Caso não apresentados todos os documentos comprobatórios, o juiz poderá ordenar à parte, se entender necessário, que proceda à exibição parcial dos livros e dos documentos,

\footnotetext{
${ }^{143}$ A comprovação de potencial impacto orçamentário apresenta relevância principalmente quando se utilizam argumentos consequencialistas, discutindo-se a possibilidade de universalização da prestação requerida também a outros que se encontrem na mesma situação do autor ou em demandas estruturais que visam à implementação ou a adequação de políticas públicas de caráter universal.
} 
extraindo-se deles a suma que interessar ao litígio, bem como reproduções autenticadas (BRASIL, 2002, art. 421).

A escassez dos recursos públicos ou o impacto orçamentário que o deferimento da prestação requerida pode causar no orçamento público e no atendimento de outras prestações e interesses relevantes não é acobertada por presunção legal que isente o Poder Público de sua prova. Assim, recorrente crítica feita pela doutrina às decisões judiciais que afastam a incidência do princípio da reserva do possível e deferem as prestações pleiteadas em juízo, desconsideram que, por vezes, o Poder Público não se desincumbiu de provar suas alegações. Por mais distorções que tais decisões possam acarretar na tutela de direitos à prestação em nível social, tal problema não pode simplesmente ser classificado/taxado de "ativismo judicial". Não cabe ao juiz desconsiderar o que a lei processual determina e julgar de acordo com as próprias convicções, negando a regra jurídica de que a prova dos fatos incumbe a quem o alegar. Por se tratar de regra processual válida, somente pode ser afastada nos casos já previstos em lei, a saber: fatos notórios; os afirmados por uma parte e confessados pela parte contrária; admitidos, no processo, como incontroversos; em cujo favor milita presunção legal de existência ou de veracidade (BRASIL, 2015, NCPC, art. 374).

Tanto as possibilidades orçamentárias e a necessidade de se preservarem outros interesses relevantes devem ser devidamente consideradas pelo julgador, quanto a Administração Pública deve também levar a sério a comprovação de suas alegações. Ao argumentar, a parte atrai para si o ônus de provar. Disponibilizados os documentos necessários pelo ente público, é importante o estabelecimento de parâmetros auxiliares que possibilitem uma melhor apuração do grau de confiabilidade epistêmica da premissa empírica. É o que se verá a seguir.

\subsubsection{Possibilidade de utilização dos instrumentos de flexibilização orçamentária (como créditos especiais, créditos suplementares, transposição e remanejamentos) e da reserva de contingência}

Um critério que pode auxiliar o juiz na atribuição do grau de confiabilidade epistêmica empírica se relaciona com a possibilidade de utilização dos instrumentos de flexibilização orçamentária. A inexistência de dotação em determinada rubrica na lei orçamentária inicialmente aprovada nem sempre vai implicar, por si só, indisponibilidade financeira 
intransponível. Isso porque as alocações podem ser remanejadas ou transpostas e a receita ampliada (MENDONÇA, 2010, p. 172) ${ }^{144}$.

Abraham (2017, p.7) ressalta que o Ministro Luiz Fux, em relatoria na ADI $n^{\circ}$ 4.633/SP (BRASIL, STF, 2018), reafirmou a jurisprudência do Supremo Tribunal Federal, iniciada na ADI n. 4.048/DF (BRASIL, STF, 2011), que reconheceu a possibilidade de controle formal e material das espécies legislativas orçamentárias, em sede de controle abstrato de constitucionalidade, rompendo com o anterior paradigma. A ampliação do controle das leis orçamentárias, aliada à ampliação do controle dos atos administrativos para além da legalidade, incluídos os praticados no âmbito da competência discricionária, expande a possibilidade de cognição por parte do Poder Judiciário em relação às escolhas públicas veiculadas por meio das leis orçamentárias e dos atos administrativos que executam o orçamento.

Assim, na análise da efetiva ocorrência da escassez dos recursos públicos para o atendimento da prestação demandada pelo autor da ação, o juiz pode seguir alguns passos, como verificar: (a) a existência ou não de verba suficiente prevista em rubrica própria; (b) se a prestação pleiteada está ou não em consonância com o planejamento e os programas constantes no Plano Plurianual; (c) se há previsão suficiente da Reserva de Contingência que possa ser destinada ao custeio da prestação pleiteada e se Lei de Diretrizes Orçamentárias autoriza a sua utilização para alocação na rubrica orçamentária pretendida pelo autor; d) se existe ou não norma orçamentária expressa que pró́be o uso dos mecanismos de flexibilização orçamentária para o custeio da prestação pleiteada pelo autor.

Constatada a insuficiência de verba em rubrica própria para o atendimento da prestação requerida, é possível analisar a possibilidade de utilização da denominada Reserva de Contingência ${ }^{145}$. Não sendo esta suficiente ou, não autorizado o seu uso pela LDO, ainda assim, o Judiciário pode chegar à conclusão de que determinada prestação estatal é taxativamente imposta pela ordem jurídica e determinar que seja fornecida, cabendo aos demais poderes reorganizar as finanças públicas ou modificar validamente o direito vigente (MENDONÇA, 2010, p. 172). Essa reorganização pode se dar tanto do lado da receita quanto

\footnotetext{
${ }^{144}$ A análise da possibilidade ou não de remanejamento, transposição de verbas alocadas nas leis orçamentárias para a efetivação de prestações não previstas inicialmente nas leis orçamentárias tem íntima relação com o que a doutrina costumou denominar de reserva do possível jurídica.

${ }^{145}$ A reserva de contingência tem previsão na Lei de Responsabilidade Fiscal (BRASIL, 2000, art. 50, III). Eduardo Varela de Gois Filho $(2009$, p. 4) assevera que a reserva de constitui provisões ou fundos tanto para a abertura de créditos adicionais, quanto para o atendimento dos riscos fiscais, passivos contingentes e imprevistos, em razão de projeções equivocadas das receitas públicas.
} 
da despesa. Neste último caso, o que é mais comum, a própria Constituição previu instrumentos de flexibilização que autorizam a modificação do que foi inicialmente previsto na lei orçamentária, uma vez que gastos não previstos ou urgentes sempre podem ocorrer, bem como uma falha no planejamento tanto da estimativa do quantum da receita quanto dos gastos no exercício financeiro.

Para Mendonça (2010, p. 171), o Judiciário poderia determinar a realização de despesas que ainda não estejam providas de lastro orçamentário, se reconhecida a imprescindibilidade da efetivação do direito fundamental. Neste caso, o ônus argumentativo do juiz será maior do que, e.g., quando os recursos estão previstos, mas imotivadamente contingenciados. Não se olvida que a "opção por determinada forma de concretização cabe precipuamente às instâncias majoritárias" (MENDONÇA, 2010, p. 169). Contudo, para o autor, o reconhecimento dessa prerrogativa não pode se dar sem "prejuízo da inafastabilidade do controle jurisdicional para avalizar a razoabilidade das escolhas realizadas ou mesmo atuar de forma mais incisiva nos casos de inércia" (MENDONÇA, 2010, p. 171). No mesmo sentido, George M. Lima afirma que

[...] não há vedação para que o juiz ordene ao Poder Público a realização de despesas para fazer valer um dado direito constitucional, até porque as normas em colisão (previsão orçamentária versus direito fundamental a ser concretizado) estariam no mesmo plano hierárquico, cabendo ao juiz dar prevalência ao direito fundamental dada a sua superioridade axiológica em relação à regra orçamentária. (LIMA apud LEITE, 2011, p. 237).

No entanto, essa posição não é pacífica. Ao considerar que o princípio da legalidade orçamentária é o informador do orçamento público, as normas dos artigos 15 a 17, da LRF (BRASIL, 2000) determinam que serão tidas por não autorizadas, irregulares ou lesivas ao patrimônio público a geração de despesas ou assunção de obrigações que não tenham estimativa do impacto orçamentário-financeiro no exercício que devam entrar em vigor. As referidas normas determinam, ainda, a necessidade de que haja declaração do ordenador de despesas no sentido de que estas despesas estão em conformidade com a LOA, com o PPA e com a LDO. Tratam-se, pois, de condições prévias para o empenho e licitação de serviços fornecimento de bens ou execução de obras. "Não existe despesa juridicamente válida que não seja submetida ao crivo orçamentário" (VENANCIO, 2016, p. 146).

Nesse raciocínio, a decisão judicial que determina a realocação dos recursos públicos 
acabaria por violar tanto o princípio da legalidade orçamentária quanto o da separação dos poderes. Outro problema é que, ainda que haja dotação suficiente na rubrica orçamentária, outras prestações anteriormente planejadas pela Administração Pública estariam comprometidas. Ou seja, para se atender ao pedido do demandante, outras prestações seriam preteridas pela limitação do recurso naquela rubrica e o Poder Judiciário estaria sobrepondo suas prioridades à dos poderes constitucionalmente legitimados para eleição das prioridades das políticas públicas.

Para Leite (2011, p.186), o orçamento não poderá ser alterado por decisão judicial, ainda que para a concretização de um direito fundamental e a realocação orçamentária não estaria no âmbito da competência do Poder Judiciário, caso o orçamento estivesse constitucionalmente adequado. Tais decisões colocariam a Administração Pública na difícil posição de escolher entre cumprir a decisão judicial ou observar o plexo de normas constitucionais orçamentárias que veda despesas sem previsão legal, ou, pior, quando não pode cumprir a decisão por ausência efetiva de recursos para atendimento do decisório.

No entanto, os que sustentam tal argumento desconsideram que a previsão dos mecanismos de flexibilização tem assento constitucional e que esses mecanismos já são constantemente utilizados pelo Poder Executivo fora das situações de concretização de direitos fundamentais sociais ou por exigência de decisão judicial. Nesse sentido, Nascimento (2019, p. 498) destaca que "apenas no dia 30/12/2014, foram publicadas 12 normas alterando a Lei de Orçamento do ano de 2014 para formalizar créditos especiais ou suplementares no valor total de R \$ 1,5 bilhão". O autor chama a atenção para o caráter retórico de algumas das objeções quanto a eventuais impactos negativos da interferência judicial no orçamento e acrescenta que "não parece razoável supor que o cumprimento de ordens judiciais poderia desorganizar aquele orçamento. Afinal, apenas é possível desorganizar algo previamente organizado - o que certamente não parece ser o caso do orçamento brasileiro" (NASCIMENTO, 2019, p. 498).

Cabe, portanto, ao ente público demandado o ônus demonstrar a impossibilidade de cumprir uma eventual decisão que reconheça o direito subjetivo do autor a uma prestação material de direito fundamental. E, no caso de haver recursos comprometidos em outras finalidades, incumbe ao Estado demonstrar que eventual remanejamento dos mesmos implicaria a ocorrência de considerável impacto na prestação de serviços em áreas igualmente prioritárias, de modo a não justificar a hipótese excepcional de transposição desses recursos de forma imediata. Outro ponto a ser considerado em relação às possibilidades orçamentárias 
de satisfação dos direitos fundamentais é que, na prática, os ingressos no caixa estatal são constantes e há sempre a possibilidade de se valer das diversas fontes de obtenção de recursos públicos analisadas no terceiro capítulo.

Moreira (2011, p. 130) afirma que não se pode admitir o mero argumento de que a Administração Pública não conta com recursos suficientes para a realização de determinado direito prestacional, na medida em que existe uma série de medidas, com custos dos mais variados, que podem dar início ao processo de satisfação do direito fundamental, determinado pela ordem constitucional. A exemplo, na hipótese o fornecimento direto da prestação material diretamente pelo Poder Público não seja possível pelas circunstâncias financeiras, pode-se analisar a possibilidade de convênios com entidades particulares, como a viabilização de acesso de estudantes à universidade. Caberia, portanto, ao Estado demonstrar o efetivo empenho no oferecimento de prestações fáticas adequadas e suficientes, de acordo com as circunstâncias sociais e econômicas demonstrando que já envidou todos os esforços possíveis.

Não se defende que o Judiciário possa estabelecer, em abstrato, a ordem de prioridades orçamentárias, desconsiderando e substituindo as decisões políticas majoritárias sempre que estas caracterizem a preterição de objetivos que o julgador entendeu mais relevantes. O que se entende razoável é afirmar que a sindicabilidade das opções orçamentárias pelo Poder Judiciário pode contribuir para identificar a presença de opções constitucionalmente impossíveis e a ausência de opções constitucionalmente necessárias. Em relação ao proposto nesta pesquisa, a análise das possibilidades de remanejamento e transposição das verbas públicas permite identificar se a insuficiência de recurso para o atendimento à prestação requerida pode ser superada pela utilização de instrumentos constitucionalmente previstos, ainda que demande nova autorização legislativa. Ademais, permite identificar se o eventual limite efetivo à possibilidade de atendimento da pretensão da parte requerente ocorre em virtude de uma questão fática ou se decorre das escolhas orçamentárias dos demais Poderes, as quais se realocadas, poderiam atender a prestação pleiteada entendida como devida, razoável.

O grau de exigência de deferência do Poder Judiciário às decisões orçamentárias dos demais poderes será determinado na medida em que não sejam constatadas decisões orçamentárias constitucionalmente impossíveis e também a observância daquelas constitucionalmente necessárias.

Portanto, se a insuficiência dos recursos puder ser superada, ainda que hipoteticamente, pela utilização dos mecanismos de flexibilização ou dos recursos destinados 
à reserva de contingência - por não existir regra proibitiva dessa medida -, o valor atribuído à confiabilidade epistêmica da premissa empírica será diminuído. Isso porque, se a escassez de recursos não é demonstrada como insuperável, a intervenção no direito fundamental pela recusa estatal em fornecer a prestação requerida não é constitucionalmente necessária e sim, conveniente, do ponto de vista político-administrativo. Ao contrário, caso seja adequadamente demonstrada a impossibilidade jurídica de utilização desses mecanismos, sem prejuízo a outros direitos e interesses relevantes, a confiabilidade epistêmica da premissa empírica será reforçada.

\subsubsection{Inexistência de violação dever jurídico ou desvios de poder orçamentário que ocasionaram a insuficiência do recurso público}

Conquanto seja lugar comum se afirmar que o Judiciário deva atentar para as possibilidades financeiras do Estado, é certo que essa exigência somente pode ser cumprida a partir da análise de um "orçamento real, que verdadeiramente indique o que está sendo feito pelo Poder Público e a que custo" (MENDONÇA, 2010, p. 173). Esse aspecto remete a outro parâmetro de aferição da confiabilidade epistêmica empírica.

Ainda que os documentos orçamentários sejam apresentados na ação, há que se ressaltar que a presença de indícios de desvio de poder orçamentário pode influir no grau de confiabilidade epistêmica da premissa empírica do princípio da reserva do possível - a escassez - que terá seu valor diminuído. Melhor esclarecendo. A irregularidade nos procedimentos orçamentários impede a correta verificação das possibilidades financeiras estatais. Constatados indícios de desvios orçamentários, a confiabilidade da alegação de limitação orçamentária restará prejudicada, uma vez que não há como proceder a um juízo de valor sobre uma peça de ficção, cujo conteúdo está eivado de ilicitudes.

A exigência de que o orçamento seja um instrumento confiável para avaliação das opções políticas de gasto também pode inibir a utilização de argumento ad terrorem nas contestações da Fazenda Pública, principalmente no sentido de que intervenções do Poder judiciário poderiam prejudicar o financiamento de outros serviços públicos, sem a demonstração da confiabilidade das premissas em que se baseiam esse argumento (MENDONÇA, 2010, p. 173).

$\mathrm{O}$ princípio da reserva do possível não considera somente o respeito às decisões alocativas feitas pelo legislador ou pelo gestor público. Em seu conceito original, a aplicação 
do princípio contém também a exigência de que o Estado demonstre que já envidou todos os esforços na concretização do direito fundamental que está sendo pleiteado pelo particular ou que a política pública ofertada é suficiente, ao menos para o atendimento ao mínimo existencial ou ao núcleo do direito fundamental. Somente após essa constatação, poderia afirmar-se que exigir maior destinação de recursos a uma determinada finalidade poderia constranger a efetivação de outros direitos fundamentais igualmente garantidos por normas constitucionais, constituindo um limite à razoabilidade da pretensão do particular. Por tal razão, a higidez orçamentária à luz das normas constitucionais e infraconstitucionais que orientam a elaboração das leis orçamentárias é imprescindível para a análise da razoabilidade das alocações e da utilização máxima dos recursos possíveis.

Em consonância com a proposta desta pesquisa, estão as afirmações de Ávila e Bitencourt sobre o papel do pesquisador, diante deste quadro. Para as autoras, seu papel é o de garantir que não se perca o sentido original da reserva do possível, para que não seja invocada para negar ao cidadão inclusive aquilo que lhe seja razoável exigir do Estado, especialmente no que toca à satisfação do mínimo existencial. "Convalidar tal ato quando notoriamente são constatados gastos públicos esdrúxulos, equivale não somente a negar o próprio sistema constitucional, como também o dos direitos humanos" (AVILA; BITENCOURT, 2017, n.p.).

Isso porque a aplicação não só formalmente irregular, mas também, materialmente não justificada, obscurecem a certeza a respeito dos limites financeiros estatais e demonstra a desproporcionalidade das alocações pela sua utilização para fins não autorizados, uma vez que o gasto ilegal dificilmente passaria no teste das máximas da adequação ou da necessidade. Além disso, o ente estatal não poderia se beneficiar da torpeza de seus agentes em detrimento do seu dever de proteção dos direitos fundamentais.

Na mesma linha defendida por Luís Carlos Martins Alves Júnior e Alexandre Santos Sampaio (2003, p. 236), assevera-se também que o princípio da reserva do possível não deve ser oponível ao princípio de direito fundamental se existe, indícios de malversação de recursos públicos e desvio de poder orçamentário. Isso porque o abuso/desvio de poder no exercício da competência orçamentária do gestor público também impede a verificação da efetiva limitação de recursos que subjacente à análise do que é razoável exigir-se do Poder Público. Assim, não seria racional justificar-se a prevalência de uma decisão alocativa antijurídica frente à força normativa do comando constitucional, que assegura o direito fundamental. Nesse sentido, Moreira (2011, p. 189) assevera que 
Apenas a reserva do possível proporcional e razoável pode ser aceita como argumento para que a alocação de recursos e a postulação de direitos fundamentais sociais não sejam atendidas de forma uniforme e imediata (MOREIRA, 2011, p. 189).

Normas extraídas de atos administrativos que veiculem decisões em desacordo com as leis orçamentárias ou com a Constituição, por estarem fora do âmbito de competência dos órgãos estatais ou extrapolarem tal competência, não têm força normativa suficiente para restringirem as posições prima facie dos princípios que garantem os direitos fundamentais. Por isso não podem ser consideradas como aptas a sustentarem razões fortes para autorizar a interferência do princípio da reserva do possível no âmbito de proteção da norma de direito fundamental. No mesmo sentido encontra-se a posição de Olsen:

Logo, há que se diferenciar entre o que não é possível porque não há,
comprovadamente, meios suficientes, mesmo depois de atendidas as normas
constitucionais que determinam alocação de recursos, e o que não é possível porque
os meios suficientes foram alocados para outras prioridades. Neste diapasão, assume
especial relevância a questão de escolha alocativa de recursos, responsável pela
decisão sobre "quanto disponibilizar e a quem atender". Para tanto, a própria
Constituição fornece parâmetros a serem respeitados, como já analisado. Uma
escolha alocativa de recursos, dentro da chamada discricionariedade administrativa,
deverá sempre respeitar os mínimos já fixados na Constituição, bem como as
prioridades por ela enumeradas. Não se trata de aprisionar as decisões políticas, mas
condicioná-las em conformidade com os valores presentes como um todo na
sociedade - e neste diapasão, todos os direitos fundamentais merecem satisfação
(OLSEN, 2006, p. 223-224).

O cerne da questão que se coloca no enfrentamento da ponderação do princípio da reserva do possível, como já asseverado, é a necessidade de se diferenciar entre o que não é "possível” porque não há, comprovadamente, recursos orçamentários suficientes, mesmo depois de atendias as normas constitucionais que determinam as alocações de recursos, e o que não é possível porque os recursos foram alocados indevidamente para outras áreas. $\mathrm{O}$ argumento genérico de insuficiência de recursos públicos não deve ser aceito quando há como pano de fundo uma ineficiência na gestão orçamentária. Para Ferreira (2018, p. 52) a “incômoda saída para inexecução das políticas públicas aponta para a invocação da reserva do possível, em flagrante desrespeito aos ditames constitucionais aos quais se encontra adstrita a emanação de todo e qualquer poder". Ressalta-se, outrossim, que a determinação judicial de alteração de uma alocação orçamentária que não atende formal e materialmente a 
Constituição e as leis orçamentárias, obstando a concretização de um direito fundamental é situação bem diferente da pretensão do requerente ou do Poder Judiciário de ver prevalecer seu posicionamento no emprego do dinheiro público.

Não sendo constatados indícios de irregularidades nas peças orçamentárias e demais documentos probatórios e, comprovado, ainda, o relevante impacto orçamentário da prestação pleiteada pelo autor, a prova documental é apta a reforçar o convencimento do julgador sobre o atingimento do limite das possibilidades financeiras do Estado para o cumprimento da prestação requerida. Nessa hipótese o valor atribuído à confiabilidade epistêmica empírica é aumentado ao máximo, o que consequentemente, reforçará o peso concreto do princípio da reserva do possível quanto utilizada a fórmula do peso refinada.

\subsection{PARÂMETROS PARA ANÁlise DA CONFIABILIDADE DA PREMISSA NORMATIVA DO PRINCIIPIO DA RESERVA DO POSSÍVEL}

Além da avaliação da confiabilidade epistêmica da premissa empírica, a adequada fundamentação da ponderação do princípio da reserva do possível vai exigir a otimização epistêmica das premissas normativas invocadas. Segundo a teoria da argumentação proposta por Alexy, o discurso jurídico, como caso especial do discurso prático geral, é limitado pelo que determina a ordem jurídica, ou seja, à Constituição, às leis e à dogmática. Não obstante, nem sempre eu juiz vai ter a certeza sobre o que essa ordem jurídica determina (TRIVISONNO, 2017, p. 124).

A incerteza sobre as premissas normativas surge quando há dúvidas sobre qual a forma correta para ponderar os princípios em jogo e qual grau de importância de satisfação deve ser atribuído a um dos princípios ou, ainda, qual o grau de intervenção sofrida pelo princípio oposto. Um dos critérios sugeridos é que quanto mais um direito fundamental que colidir com o princípio da reserva do possível for delimitado pela ordem jurídica constitucional e infraconstitucional, maior a certeza se pode extrair de que esse direito deve prevalecer, reduzindo o valor sobre a certeza epistêmica normativa do princípio da reserva do possível. Contudo, a inflação legislativa e a opacidade do direito minam o conceito de certeza jurídica e, por vezes, os próprios especialistas não estão em condições de conhecer todo o direito em vigor. Ademais, mesmo quando aplicado racionalmente, o direito pode gerar decisões diversas sobre idênticas questões jurídicas (CAMBI, 2016, p. 192).

A existência de certo consenso jurídico sobre a importância da satisfação de 
determinado bem protegido por um direito fundamental e sobre o reconhecimento de uma adequada delimitação de seu conteúdo pela ordem jurídica, reforçaria o peso do princípio colidente. Neste caso, será exigido um grau maior na valoração epistêmica do princípio da reserva do possível para que este restrinja as posições jurídicas prima facie daquele direito fundamental. Por outro lado, quanto maiores as controvérsias em torno das questões normativas do princípio colidente, da delimitação de seu conteúdo e da importância em sua satisfação, maior o grau de confiabilidade epistêmica normativa atribuída ao princípio da reserva do possível, aumentando o seu peso concreto.

A consideração a priori de todas as restrições e interferências impostas pelos princípios colidentes ao princípio da reserva do possível, seria tarefa inatingível no âmbito desta pesquisa, vez que haveria uma gama de possibilidades jurídicas que seriam determinadas, caso a caso, de acordo com as especificidades jurídicas do princípio colidente. Assim, o que se entende possível neste trabalho é determinar o grau de confiabilidade da premissa normativa a partir da exclusão de conteúdos constitucionalmente impossíveis ou conteúdos proibidos e de conteúdos constitucionalmente necessários para a prevalência do princípio da reserva do possível. Constatadas essas hipóteses proibidas e impossíveis, esse princípio não deve prevalecer. Consequentemente, o valor epistêmico atribuído às premissas que reforçam a satisfação deste princípio e, portanto, do grau de intervenção no direito fundamental será reduzido, reforçando o peso concreto do princípio colidente. No caso dos conteúdos necessários há um reforço do valor epistêmico atribuído às premissas a favor do princípio da reserva do possível, diminuindo o peso concreto do princípio colidente. Essas hipóteses denotam os espaços normativos excluídos da discricionariedade do legislador orçamentário. Em razão das limitações acima referidas e da proposta desta pesquisa bibliográfica, puderam ser extraídos dois critérios ou parâmetros objetivos para a valoração da confiabilidade da premissa normativa do princípio da reserva do possível, a seguir analisados.

\subsubsection{A aplicação do princípio da reserva do possível não obsta a efetivação de prestações inseridas no mínimo existencial e outros direitos subjetivos reconhecidos pela ordem jurídica}

Como já explicitado no segundo capítulo, a inoponibilidade da reserva do possível ao conteúdo do mínimo existencial é aceita tanto na doutrina quanto na jurisprudência brasileira 
bem como a exigência de proteção ao núcleo essencial dos direitos fundamentais, muito embora, neste último caso, pela adoção da teoria externa, em alguns casos ele poderia ser atingido. Pela aplicação da Teoria dos Princípios de Alexy, parte-se da premissa que o princípio da reserva do possível não vai incidir sobre posições definitivas e sim sobre as posições prima facie do princípio colidente, ou seja, "naquilo que, no âmbito de proteção do princípio jurídico, corresponda a algo de excedente e que pode ser restringido e extraído do acervo de normas constitucionais" (ALEXY, 2011, p. 280). Dessa forma, a maior delimitação jurídica do conteúdo de um direito fundamental, aproximando de sua caracterização como direito subjetivo definitivo, diminui a confiabilidade epistêmica normativa em relação à importância da satisfação do princípio da reserva do possível.

Como as prestações referentes ao mínimo existencial tratam de posições definitivas do indivíduo perante o Estado, afasta-se, nestes casos, a possibilidade de ponderação com o princípio da reserva do possível, constituindo um limite do sistema jurídico-constitucional à incidência do princípio. Para Moreira (2017, p.190), a necessidade de preservação do mínimo existencial constitui limite ao princípio da reserva do possível, que reforça a existência de um núcleo intangível relacionado com a dignidade humana, que deve ser promovido pelo Estado a despeito da escassez de recursos. Segundo Alexy, "a dignidade humana tem precedência sobre as possibilidades financeiras quando o mínimo existencial não se vê garantido" (ALEXY, 2015a, p.177). Na prática, é como se houvesse uma presunção da suficiência de recursos para o atendimento das prestações do mínimo existencial.

Noutro giro, a dimensão objetiva dos direitos fundamentais, traz aos poderes públicos a obrigatoriedade de garantia do núcleo dos direitos fundamentais sociais. Essa obrigação irradia sobre as decisões do legislador orçamentário e do administrador público e deve se refletir no orçamento público que é a peça em que serão concretizadas as escolhas políticas fundamentais da sociedade (MOURA E RIBEIRO, 2017, p. 230). Defende-se, pois, que são razoáveis as alocações financeiras quando o mínimo existencial e o núcleo essencial dos direitos fundamentais estiverem pelas escolhas alocativas resguardados.

Moreira (2017, p. 177) afirma, com base nas lições de Jane Reis Gonçalves Pereira, que quanto mais severa for uma restrição a direito fundamental, atingindo seu núcleo essencial, menores as chances de que a importância da implementação de um princípio antagônico seja apta a justificar a restrição. Isso significa que, quanto mais se afastar um princípio jurídico, mais resistente ele se torna, de modo que, em certas situações, a extrema gravidade da restrição a um princípio exigirá a correspondente extrema gravidade da 
importância de satisfação do princípio colidente.

Quanto mais extremado o grau (tanto de restrição de um princípio, quanto de importância de satisfação do outro), mais excepcional é a circunstância de sua ocorrência. Assim, quanto maior o grau de afetação do direito fundamental, maior deve ser a importância de satisfação do princípio da reserva do possível. Portanto, quanto mais próxima às prestações do mínimo existencial ou do núcleo essencial do direito fundamental protegido for a restrição, menor valor deve ser atribuído à confiabilidade epistêmica normativa da importância de satisfação do princípio da reserva do possível. Isso significa que menores são as chances de preponderância desse princípio quanto mais as intervenções se aproximam do núcleo essencial dos direitos fundamentais e do mínimo existencial. Ao contrário, quanto mais a prestação pleiteada se afastar do núcleo essencial de um direito e, mais ainda, das prestações que compõe o mínimo existencial, maior grau de confiabilidade deve ser atribuído à premissa normativa do princípio da reserva do possível.

Por fim, se as prestações requeridas estiverem inseridas no âmbito do mínimo existencial, não mais se procede à ponderação, pois, como essas prestações constituem direito definitivo, possuem estrutura de aplicação binária e não gradual, sendo excluída a priori $a$ possibilidade de prevalência do princípio da reserva do possível. Nesse caso, o valor a ser atribuído à confiabilidade epistêmica da premissa normativa é nulo ou não comprovado, pois neste caso o princípio não é ponderável.

\subsubsection{Existência de decisão anterior vinculante do tribunal ou precedente judicial que tenha estabelecido regra de precedência do princípio da reserva do possível, nas mesmas condições, em relação ao mesmo princípio colidente}

O respeito aos precedentes como condição de segurança jurídica é mais tradicionalmente utilizado nos países com o sistema jurídico common law, mediante o instituto stare decisis ${ }^{146}$. Em países ligados ao sistema jurídico civil law, como é o caso do Brasil, os precedentes judiciais, em regra, não são vinculantes, mas assumem um caráter

\footnotetext{
${ }^{146}$ Sobre o stare decisis, Porto afirma que "na proposta clássica, encerra a ideia: stare decisis et non quieta movere, ou, deixe-se a decisão firmada e não altere-se [sic] as coisas que foram assim dispostas, ou, ainda, ficar com o que foi decidido e não mover o que está em repouso". Esclarece, ainda, que a proposta é que "a decisão jurisdicional assuma a função não apenas de dirimir determinada controvérsia posta à apreciação do juízo, mas, além disto, também desempenhe a tarefa de estabelecer um precedente com força vinculante, de modo a assegurar que no futuro, em caso análogo, venha a ser decidido da mesma forma" (PORTO, 2006, p. $7-8)$
} 
persuasivo (CAMBI, 2016, p. 193). Contudo, a doutrina defende que existem boas razões para que os precedentes sejam observados, dentre eles os princípios da segurança jurídica, da isonomia ou da igualdade formal, além de razões pragmáticas como a possibilidade de promover a duração razoável dos processos judiciais e, inclusive, inibir potencialmente as demandas temerárias.

Primeiramente, destaca-se que precedentes judiciais se diferem do que se denomina de jurisprudência - como um conjunto de decisões no mesmo sentido sobre determinada questão jurídica - na medida em que aqueles são decisões aptas a definirem o sentido do direito, mediante as melhores razões (razões determinantes ou ratio decidendi) necessárias para servirem de orientação para os juízes e tribunais ordinários, bem como para a sociedade (CAMBI, 2016, p. 187). Alexy (2017, p. 259) afirma que uma teoria da argumentação jurídica que não considere o papel dos precedentes omitiria seus aspectos essenciais. Para ele, o fundamento do uso dos precedentes se baseia no princípio da universalidade, relacionado à concepção formal de justiça de "tratar de igual maneira ao igual”. Assim, possuem um caráter universalizante, na medida em que servem para casos similares, evitando-se decisões distintas. Alexy formula duas regras gerais para o uso do precedente: “(J.13) Quando se puder citar um precedente a favor ou contra uma decisão, deve-se fazê-lo" e "(J.14) Quem quiser se afastar de um precedente, assume a carga da argumentação" (ALEXY, 2017, p. 262).

No Brasil, a Lei 13.105/2015 (CPC), em consonância com as alterações introduzidas pela EC no 45/2004, ampliou de forma significativa a força dos precedentes judiciais como fonte de direito, estabelecendo inúmeras regras, dentre elas a que determina que "não se considera fundamentada a decisão que "deixar de seguir enunciado de súmula, jurisprudência ou precedente invocado pela parte, sem demonstrar a existência de distinção no caso em julgamento ou a superação do entendimento" (BRASIL, 2015, art. 489, §1 ${ }^{\text {o }}$, VI). Incumbem ao STF e ao STJ a função de unificar a interpretação da Constituição e das leis, sendo, portanto, consideradas com o status de "Cortes de Precedentes" (CAMBI, 2016, p. 206). Ressalta-se que, em regra, as decisões do STF e do STJ não vinculam a Administração Pública, com exceção dos casos de decisões proferidas em ações declaratórias de constitucionalidade (ADC), de ações diretas de inconstitucionalidade (ADI) e as súmulas vinculantes. Nos casos em que a norma jurídica processual atribui vinculatividade à decisão, o peso da confiabilidade epistêmica normativa é reforçado, se a decisão paradigma tiver reconhecido no âmbito da ponderação a prevalência do princípio da reserva do possível. Não se pode olvidar que nem sempre dois casos serão exatamente iguais, cabendo nessas hipóteses 
a utilização das técnicas do distinguishing (distinção) e overruling (superação) para justificar o afastamento do precedente (ALEXY, 2017, p. 263). Para Cambi (2016, p. 206), fora dessas hipóteses, a não observância dos precedentes judiciais pode caracterizar arbítrio judicial.

$\mathrm{O}$ uso do precedente significa a aplicação da norma que subjaz à decisão do precedente e pode também pode contribuir para a segurança jurídica e para a proteção da confiança na aplicação do Direito (ALEXY, 2017, p. 260-261). Exige, ainda, "verificar se os mesmos fatos que deram suporte para as decisões estão presentes no caso a ser julgado" (CAMBI, 2016, p. 191). Da ratio decidendi extrai-se a regra de direito que foi utilizada como fundamento direto da decisão sobre os fatos específicos do caso em que se fixou a decisãoparadigma. Difere-se dos argumentos obter dictum na medida em que estes não influenciam significativamente na solução encontrada, não fazendo parte do fundamento jurídico, embora úteis ao raciocínio (CAMBI, 2016, p. 194-195). Daí a importância da motivação das decisões que exigem, para sua melhor compreensão, tanto uma justificação interna, que corresponde à relação lógica entre as premissas de direito e de fato que se põe como fundamentação, como uma justificação externa que diz respeito à justificação das próprias premissas, com o objetivo de verificar sua correção (ALEXY, 2017, p. 213).

Com base na lei de colisão formulada por Alexy, pode-se afirmar que a existência de precedentes ou decisões vinculantes que já estabeleceram a prevalência do princípio da reserva do possível em relação a outros princípios de direito fundamental é razão que deve ser considerada na valoração epistêmica da premissa normativa, pois deles se poderá extrair uma regra que determina que, presentes semelhantes condições, o princípio terá prevalência, aumentando consideravelmente o grau de confiabilidade e, consequentemente, do peso relativo do princípio da reserva do possível. Neste caso, não havendo razões para se justificar que a regra extraída do precedente está superada ou não se aplica ao caso em análise, o peso maior atribuído à confiabilidade epistêmica normativa do princípio da reserva do possível é exigência dos princípios da segurança jurídica e da isonomia. 


\title{
PARTE II - PESQUISA EMPÍRICA - PARÂMETROS DE CONFIABILIDADE EPISTEMICA DO PRINCÍPIO DA RESERVA DO POSSÍVEL $E$ A JURISPRUDÊNCIA DO STF E DO STJ
}

\section{METODOLOGIA}

A pesquisa empírica, há muito disseminada nas ciências sociais, tem ganhado espaço e importância no campo da ciência jurídica. Segundo Roberto Kant de Lima:

\begin{abstract}
Promover a pesquisa empírica no campo das práticas judiciárias, por exemplo, pode explicitar paradoxos cuidadosamente ocultos, como aqueles que estão presentes no sistema de Justiça criminal, no qual a prática dos atores do sistema está submetida a uma teoria distinta daquela explicitamente proposta pelos livros e ensinada nos cursos jurídicos (LIMA, apud COACCI, 2013, p. 88).
\end{abstract}

O desenho da pesquisa é um guia que orienta o pesquisador no desenvolvimento de um problema de pesquisa sólido, permitindo mobilizar corretamente a teoria que lhe serve de base, selecionar dados de qualidade e realizar articulações válidas entre dados e teoria (KING; KEOHANE; VERBA, apud COACCI, 2013, p. 89).

O objetivo traçado para a presente pesquisa foi identificar quantitativamente a ocorrência dos parâmetros de confiabilidade epistêmica empírica e normativa relacionados ao princípio da reserva do possível nos acórdãos proferidos pelo Supremo Tribunal Federal (STF) e pelo Superior Tribunal de Justiça (STJ), em determinado período de tempo. A partir da análise qualitativa desses acórdãos, seria possível correlacionar a ocorrência dos parâmetros com o grau de confiabilidade epistêmica das premissas normativas e empíricas com que os tribunais estão trabalhando para decidir sobre a prevalência ou não do princípio da reserva do possível em relação a um princípio colidente, questão esta que deve ser relevante para a solução da controvérsia.

Visando à consecução do objetivo traçado, foi eleito o método de análise documental. A pesquisa de acórdãos e de peças processuais é uma das modalidades de pesquisa documental e possui como fonte principal de dados documentos escritos oficiais do poder judiciário (mesmo inseridos no ambiente virtual). A análise do conteúdo desses documentos permitiria extrair a forma como determinado instituto jurídico está sendo tratado pelos atores do processo - autor, réu e juiz. Nesta pesquisa, foi efetuada a análise do conteúdo das peças 
processuais e acórdãos referentes aos processos judiciais eletrônicos disponíveis para a consulta e que atendiam os critérios fixados para a pesquisa, adiante especificados.

Foram necessários os seguintes recortes: institucional, temático, processual e temporal. A impossibilidade fática em se analisarem todos os processos em todos os Tribunais brasileiros determinou necessidade de realizar um recorte institucional do órgão julgador. Foram estabelecidos os seguintes critérios para a seleção do órgão julgador: a relevância decisória no ordenamento jurídico-constitucional nacional, a disponibilidade para a consulta dos processos e peças processuais relacionados ao objeto de pesquisa na forma virtual e a competência para uniformização de jurisprudência em âmbito nacional. Assim, o recorte institucional foi adstrito aos acórdãos do Supremo Tribunal Federal (STF) e do Superior Tribunal de Justiça (STJ).

O Supremo Tribunal Federal possui atribuições definidas na Constituição Federal, nas quais estão inseridas funções jurisdicionais para análise da constitucionalidade de leis e atos normativos federais e estaduais, em âmbito recursal, mediante recurso extraordinário e, originariamente, em ações de controle concentrado de constitucionalidade, como ação direta de inconstitucionalidade (ADI), ação direta de constitucionalidade (ADC) e arguição de descumprimento de preceito fundamental (ADPF). Com a Emenda Constitucional 45/2004, foi introduzida a possibilidade de o Supremo Tribunal Federal aprovar, após reiteradas decisões sobre matéria constitucional, súmulas com efeito vinculante em relação aos demais órgãos do Poder Judiciário e à administração pública direta e indireta, nas esferas federal, estadual e municipal (art. 103-A, da CF/1988). Portanto, constitui órgão de cúpula, que orienta a interpretação e definição do conteúdo das normas constitucionais, dentre elas, as normas de caráter principiológico, como é o caso do objeto desta pesquisa. O Supremo Tribunal Federal é composto pelos seguintes órgãos: o Plenário, as Turmas e o Presidente (BRASIL, 1980, RISTF, art. $3^{\circ}$ ). Cada uma das duas Turmas é constituída por cinco Ministros e presidida pelo mais antigo dentre seus membros, por um período de um ano, sendo somente permitida a recondução após todos os seus integrantes terem exercido a Presidência, observada a ordem decrescente de antiguidade (BRASIL, 1980, RISTF, art. $4^{\circ}, \S 1^{\circ}$ ).

Por sua vez, o Superior Tribunal de Justiça (STJ) constitui órgão responsável por uniformizar a interpretação das leis federais em todo o Brasil. É responsável pela solução definitiva dos casos civis e criminais que não envolvam matéria constitucional nem a justiça especializada. O recurso especial é prioritariamente o tipo de ação que possibilita ao STJ uniformizar as interpretações divergentes sobre um determinado dispositivo de lei federal. 
Quando há múltiplos recursos com fundamento na mesma questão legal (recursos repetitivos), o STJ pode determinar a suspensão dos processos que tratem da mesma matéria, até que julgue um recurso selecionado como representativo da controvérsia. Tomada tal providência e decidida a controvérsia, fixa-se a orientação a ser adotada pelos demais tribunais em relação aos recursos pendentes. Assim, caso a decisão do tribunal local não esteja conforme a orientação firmada pelo STJ no recurso repetitivo, o tribunal local vai julgar novamente o caso. A decisão do STJ nestes casos tem eficácia vinculante. Na hipótese do tribunal local insistir em interpretar a lei de forma divergente do acórdão-paradigma, o recurso especial terá continuidade e poderá ser apreciado pelo STJ, nos termos do artigo 1.041 do Código de Processo Civil vigente. Nestes casos, na justificativa da decisão de manutenção do entendimento contrariamente à orientação do STJ, o tribunal local terá que demonstrar o distinguishing ou o overruling, ou seja, enquanto a decisão-paradigma do STJ não for superada, os casos semelhantes julgados pelos tribunais locais devem obrigatoriamente, pelo art. 1.040 do CPC, segui-la. São precedentes dotados de vinculatividade, consoante se extrai do artigo 927, inciso III, do CPC, embora não vincule a Administração Pública diretamente.

Quanto à visualização das peças processuais no site desse tribunal, é informado que, de acordo com a Resolução $n^{\circ}$ 427/2010 do STF e da Resolução $n^{\circ}$ 121/2010 do Conselho Nacional de Justiça, consideram-se públicas as certidões e atos decisórios produzidos pelo Tribunal, bem como os dados básicos do processo. Tais certidões e atos decisórios estão disponíveis para consulta, na página eletrônica do STF, no menu "acompanhamento processual". Contudo, a visualização das peças eletrônicas dos feitos, desde 22/11/2010, passou a ser realizada apenas por meio do Portal do Processo Eletrônico. Essa consulta atualmente exige o credenciamento do consulente e a utilização de certificação digital nos padrões definidos pela ICP-Brasil. As ações de controle concentrado de constitucionalidade, bem como os recursos extraordinários paradigmas de repercussão geral, por serem de interesse coletivo, estão disponibilizados para consulta irrestrita, no sítio do STF. Os feitos que tramitam em segredo de justiça poderão ser acessados somente pelos advogados e partes cadastrados no processo ${ }^{147}$. Essa exigência limitou a análise das peças nesta pesquisa a somente aquelas que estavam disponíveis publicamente.

147 Informações mais detalhadas podem ser obtidas no portal do STF. Disponível em: $<$ http://portal.stf.jus.br/textos/verTexto.asp?servico=jurisprudenciaRepercussaoGeral\&pagina=apresentacao $>$ , Acesso em: 4 dez.2020. 
Os 33 ministros do STJ dividem-se internamente para julgar a maioria das matérias em órgãos especializados. O Plenário é composto por todos os ministros do STJ que também possui competência administrativa. A Corte Especial é composta pelos 15 ministros mais antigos do Tribunal e julga as ações penais contra governadores e outras autoridades. A Corte também é responsável por decidir recursos quando há interpretação divergente entre os órgãos especializados do Tribunal. O STJ conta com três Seções que são especializadas para julgar, dentre outros, mandados de segurança, reclamações e conflitos de competência. Elas também são responsáveis pelo julgamento dos recursos repetitivos. Cada Seção reúne os ministros de duas Turmas, também especializadas. As Seções são compostas por dez ministros e as Turmas por cinco ministros cada. Nas Turmas são julgados, por exemplo, os recursos especiais sem caráter repetitivo, os habeas corpus criminais, recursos em habeas corpus e recursos em mandado de segurança.

Em relação ao recorte temático, a pesquisa empírica limitou-se à busca, nos sites dos tribunais selecionados, da jurisprudência catalogada, a partir da expressão de busca reserva adj do adj possível. Essa opção metodológica abrange os vários tratamentos terminológicos que foram identificados na pesquisa bibliográfica como: reserva do possível, princípio da reserva do possível, cláusula da reserva do possível e reserva do financeiramente possível, possibilitando que a busca realizada compreendesse todas as denominações incorporadas pelo Tribunal em sua jurisprudência. Posteriormente, verificaram-se alterações no mecanismo de busca de resultados de ambos os sites, razão pela qual foi necessária a adaptação da expressão de busca ao novo sistema, culminando na alteração do termo de busca para "reserva do possível" (entre aspas duplas), que possibilitou obter os mesmos resultados da busca inicial em ambos os sites.

O resultado retornado pelo site incluiu todos os acórdãos em que a expressão de busca foi identificada, tanto no corpo dos acórdãos (votos), quanto nas ementas. Tal metodologia se faz necessária pelo procedimento por meio do qual os acórdãos são produzidos pelos tribunais brasileiros, ou seja, de forma agregativa. Isso significa que cada Ministro emite seu voto sobre a lide. A ementa é formulada após a juntada de todos os votos, da deliberação e decisão dos Ministros sobre as questões da lide postas pelo Relator. A aprovação pode se dar por maioria ou por unanimidade ou, ainda, com quórum qualificado eventualmente exigido pela legislação. $\mathrm{Na}$ ementa, também são indicados os votos vencidos, que também são incluídos nos resultados da busca. 
Dos resultados retornados, foram excluídas as decisões monocráticas, as decisões interlocutórias, incluídas as decisões de mera admissibilidade de recursos, as decisões não definitivas de mérito (como decisões suspensivas de liminares e em tutela antecipada), bem como as decisões em que o termo de busca não foi tratado como questão relevante para a solução da controvérsia processual. A partir desses critérios, foram mantidos os acórdãos, proferidos pelos órgãos colegiados de ambos tribunais superiores (Tribunal Pleno, Turmas e Seções), referentes a decisões definitivas de mérito, em que o princípio da reserva do possível era questão necessária para a solução da lide, o que possibilitou extrair a posição final de cada Tribunal sobre o tema abordado, excluindo-se entendimentos isolados dos Ministros não ratificados pelo Tribunal.

O termo inicial do recorte temporal foi fixado em 2010, ano em que a visualização das peças eletrônicas dos processos passou a ser realizada apenas por meio do Portal do Processo Eletrônico, de modo a possibilitar o máximo levantamento possível de peças processuais e documentos probatórios. Verificou-se que os primeiros peticionamentos, via processo eletrônico, iniciaram-se no âmbito dos Recursos Extraordinários, instituídos pela Resolução $n^{0} 350 / 2007$. Com a Resolução $n^{0} 417 / 2009$, o peticionamento eletrônico foi ampliado, tornando-se obrigatório para algumas classes.

A partir de 1/2/2010, não só o peticionamento, mas as seguintes classes processuais tiveram o seu trâmite em formato exclusivamente eletrônico no STF: Ação Direta de Inconstitucionalidade (ADI); Ação Direta de Inconstitucionalidade por Omissão (ADO); (Ação Declaratória de Constitucionalidade (ADC); Arguição de Descumprimento de Preceito Fundamental (ADPF); Reclamação (Rcl) e Proposta de Súmula Vinculante (PSV). Após $1^{\circ}$ de agosto de 2010, nos termos do art. 32, da Resolução $n^{\circ}$ 427/2010, novas classes processuais foram acrescidas ao rol do peticionamento e trâmite em meio exclusivamente eletrônico: Ação Rescisória (AR); Ação Cautelar (AC); Habeas Corpus (HC); Mandado de Segurança (MS); Mandado de Injunção (MI); Suspensão de liminar (SL); Suspensão de Segurança (SS) e Suspensão de Tutela Antecipada (STA). Ainda, em qualquer classe de processo, a requerimento da parte ou de ofício por determinação do Ministro Relator, a resolução autorizou a conversão de processos físicos em eletrônicos. Nesse sentido, a partir de 2010, um grande volume de feitos de natureza recursal teve seu trâmite convertido para o meio eletrônico. Para abarcar o maior número possível de visualização de peças processuais, não houve a fixação de termo final no levantamento, tendo sido analisadas todas as peças 
relativas às ações que retornaram da busca e que atendiam aos critérios fixados, quando se passou para a etapa de redação da dissertação.

A seguir serão apresentados os resultados alcançados nesta pesquisa documental.

\subsection{PESQUISA EMPÍRICA}

Foi realizada análise qualitativa das decisões, com a identificação dos critérios adotados pela pesquisa. A análise quantitativa dos dados deu-se posteriormente, no momento da tabulação cruzada.

A partir dos critérios delineados, o corpus para análise inicial foi composto da seguinte forma, em cada Tribunal:

a) resultados da pesquisa no Supremo Tribunal Federal: no site oficial do STF (https://stf.jus.br) foi acessado o link de Jurisprudência > Pesquisa avançada. Foi selecionada a opção Acórdãos. O termo de busca inserido foi "reserva do possível". No campo Data foi incluída a referência inicial 01/01/2010 ${ }^{148}$. A seguir, foram selecionadas, no campo Base, a opção Acórdãos e, no campo Órgão Julgador, a opção Tribunal Pleno. Com esses parâmetros fixados, foram retornados 38 resultados, distribuídos nas seguintes classes, classificados pelo próprio site em: $18 \mathrm{RE}, 6 \mathrm{AD}, 4 \mathrm{SL}, 3 \mathrm{STA}, 2 \mathrm{ADPF}, 2 \mathrm{ARE}, 1 \mathrm{ACO}, 1 \mathrm{ADC}$ e $1 \mathrm{ADO}$.

Desse total foram excluídas decisões de admissibilidade, interlocutórias de tutelas antecipadas e liminares, embargos de declaração rejeitados, agravos negados (impedindo o prosseguimento dos recursos), decisões de mérito em que o princípio da reserva do possível foi citado, mas não era relevante para a solução da lide. Totalizaram 30 decisões excluídas a partir da aplicação desses critérios. Foram analisados 9 acórdãos que atendiam aos critérios fixados para a pesquisa.

b) resultados da pesquisa no Superior Tribunal de Justiça - STJ: no site oficial do STJ (https://https://www.stj.jus.br) foi acessado o link de Jurisprudência do STJ > Pesquisa avançada. O termo de busca inserido foi "reserva adj do adj possível"149. No campo "Data" foi incluída somente a referência ao termo inicial 01/01/2010. Foram retornados 127 acórdãos como resultado da busca. Desse total, foram excluídas decisões de admissibilidade, interlocutórias, embargos de declaração rejeitados ou sem efeitos infringentes, agravos

\footnotetext{
${ }^{148}$ Considerando as recentes mudanças no sistema de busca do site o mesmo resultado pode ser obtido, a título de reprodução da metodologia, adicionando-se no campo Data de julgamento a data final 30/06/2020 e preenchendo o campo Data de publicação com os seguintes parâmetros: 01/01/2010 e 11/09/2020.

$149 \mathrm{O}$ operador adj é utilizado para que se indiquem quantas palavras pode haver entre aquelas integrantes do termo de busca; a não colocação de nenhum número após o conector significa que não deve haver nenhuma palavra entre aquelas do próprio termo, que deve ser buscado então na sua literalidade.
} 
regimentais e internos negados, decisões de mérito em que o princípio da reserva do possível foi citado, mas não era relevante para a solução da lide e, ainda, as ações em que o principio foi alegado pela parte, mas na decisão foi afastada de plano sua incidência ${ }^{150}$. Totalizaram 70 decisões excluídas a partir da aplicação desses critérios. Foram analisados 56 acórdãos que atendiam, inicialmente, aos requisitos fixados para a pesquisa. Iniciada a leitura dos acórdãos no âmbito do STJ, constatou-se que a ponderação do princípio da reserva do possível deixou de ser realizada em alguns casos porque o princípio ou direito colidente possuía natureza constitucional, afastando a competência daquele tribunal para essa análise ${ }^{151}$. Essas ações também foram excluídas do cômputo geral.

De igual modo, nas ações de mandado de segurança analisadas no âmbito do STJ, cujo objeto era o cumprimento da obrigação estatal de fazer consistente no dever de indenizar os anistiados políticos nos termos da Lei $n^{\circ} 10.559 / 2002$, o tribunal entendeu que a obrigação de fazer consistente no pagamento determinado nas respectivas Portarias que concederam a anistia e determinaram o pagamento dos valores aos anistiados e seus retroativos não estaria "cingido à reserva do possível". Assim, analogamente ao que ocorre com a confrontação do principio da reserva do possível com prestações relativas ao mínimo existencial, foi afastada de plano a possibilidade de ponderação em sede de Mandado de Segurança, prevalecendo o direito líquido e certo dos anistiados em 100\% dessas ações. Essas ações foram retiradas do cômputo total, muito embora os precedentes delas extraídos constituem dado relevante para o tema, não levantado na pesquisa bibliográfica. Assim, foi consolidada nesses precedentes a prevalência do direito líquido e certo à indenização de valores retroativos aos anistiados políticos, afastando de plano a possibilidade de ponderação com o principio da reserva do possível nestas ações, principalmente quando demonstrado que houve a consignação de créditos orçamentários específicos para o pagamento dos valores e decorrido o prazo fixado na Lei $n^{\circ} 10.559 / 2002$.

É importante ressaltar que as ações de mandado de segurança demandam a exigência de prova pré-constituída do direito líquido e certo, reduzindo a amplitude da cognição tanto

\footnotetext{
${ }^{150}$ Um exemplo dessa situação pode ser constatada no RESP $n^{\circ}$ 962934/MS que tratava do direito à indenização de encarcerados em situação desumana. O STJ na ementa do acórdão consignou não se tratar de assegurar o mínimo existencial nem de adequação da alegação do principio da reserva do possível (BRASIL, STJ, 2010, p. 1).

${ }^{151}$ No Recurso Especial n. 1.771.912/PR julgado pela $2^{\text {a }}$ Seção do STJ, o Ministro Herman Benjamim, relator do processo, afirmou que "a matéria foi debatida com fundamento eminentemente constitucional, sendo a sua apreciação de competência exclusiva do Supremo Tribunal Federal, conforme dispõe o art. 102, III, do permissivo constitucional. Assim, não é possível analisar a tese recursal sob pena de usurpar a competência do Supremo Tribunal Federal estabelecida nas alíneas do inciso III do artigo 102 da Constituição Federal" (BRASIL, STJ, MS 1.771.912/PR, 2011, p. 5).
} 
do direito quanto da prova da escassez de recursos ou do impacto orçamentário. Em alguns julgados, a $1^{\text {a }}$ Seção do STJ entendeu que não seria possível realizar a ponderação do princípio da reserva do possível no âmbito de mandados de segurança. Comprovado o direito líquido e certo, o pedido deveria ser concedido ${ }^{152}$. Foram computadas 41 ações desta natureza no STJ no período analisado e excluídas no total de ações, restando o total de 15 ações que preenchiam os requisitos da presente pesquisa e consideradas nos resultados finais.

Os documentos utilizados como fonte da pesquisa foram o acórdão do julgamento e as peças processuais disponíveis que compuseram o respectivo processo, uma vez que a investigação procurou verificar se houve ou não juntada de provas das alegações trazidas pelas partes. Os dados colhidos desses documentos foram catalogados em uma tabela-padrão (Apêndice A) que continha as seguintes variáveis, identificadas como relevantes a partir da pesquisa bibliográfica realizada:

- Dados do processo;

- Descrição do caso;

- Principais razões da decisão;

- Parâmetros da confiabilidade epistêmica empírica;

- Parâmetros da confiabilidade epistêmica normativa.

A cada processo judicial corresponde uma tabela padrão. Ao final, os dados de todas as tabelas-padrão foram reunidos em uma tabulação cruzada por tribunal (Apêndices B e C), viabilizando-se a análise quantitativa do material levantado. Essa organização permitiu realizar as inferências sobre o tratamento da confiabilidade epistêmica das premissas empíricas e normativas do instituto jurídico eleito como objeto da presente pesquisa: o princípio da reserva do possível.

O foco da análise dos dados se ateve à verificação da ocorrência dos parâmetros de confiabilidade das premissas empíricas e normativas que foram divididas em dois blocos de variáveis. Cada variável recebeu uma das três respostas/um dos três enquadramentos abaixo de acordo com a observação realizada:

${ }^{152}$ Um exemplo dessa afirmação se deu no Mandado de Segurança n. 15.612-DF, apreciado pelo STJ, em que o Ministro Humberto Martins, relator do processo, afirmou que “[...] é impossível realizar uma ponderação, em sede de mandamus, para decidir se o alegado direito do impetrante deve ser provido em detrimento de outros programas sociais. Assim, não cabe ao Poder Judiciário decidir tendo em consideração que a potencial satisfação de um direito poderá gerar prejuízos na gestão de outros programas. A análise dar-se-á unicamente em termos jurídicos, ou seja, se existe o direito do impetrante, e, logo, se deve ser provido" (BRASIL, STJ, MS 15.612/DF, d.j. 24.08.2011, p. 16-17). 
- NR (não referenciado): marcado quando a ocorrência do respectivo parâmetro não foi passível de verificação, seja porque as peças processuais estavam indisponíveis para a visualização, seja porque não houve menção de sua existência no acórdão;

- NÃO: quando a ocorrência do parâmetro não foi comprovada pelas peças processuais; ou não foi reconhecida a comprovação pelos Ministros no acórdão, ou, ainda, quando as provas trazidas aos autos provaram o oposto daquilo a que se refere o parâmetro;

- SIM: quando a ocorrência do parâmetro foi comprovada pelas peças processuais ou reconhecida a sua comprovação pelos Ministros nos votos que fundamentaram o acórdão.

A partir da análise de cada resposta atribuída às variáveis dos parâmetros da confiabilidade empírica e normativa, foi utilizada a escala triádica proposta por Alexy aos níveis epistêmicos utilizados na fórmula do peso ("não evidentemente falso", "plausível”, "certo ou confiável") aos quais foram acrescidos os itens "prejudicado" e "não comprovado", não constantes da proposta do jusfilósofo, mas que se fizeram necessários para a realidade desta pesquisa ${ }^{153}$. Em relação ao grau "não comprovado" associa-se o valor ínfimo ou zero para o grau de certeza da premissa epistêmica que sustenta a intervenção no principio colidente com o principio da reserva do possível. O grau prejudicado somente está sendo incorporado à pesquisa em razão da impossibilidade de acesso a todas as peças processuais, o que em um caso concreto não ocorreria.

No que tange à confiabilidade epistêmica empírica, o enquadramento em uma das cinco possibilidades descritas foi realizado a partir da verificação da prova do impacto orçamentário, da insuficiência (escassez) de recursos e da intransponibilidade da escassez (seja por impossibilidade de utilização dos instrumentos de flexibilização ou da impossibilidade de auferir novos recursos orçamentários), conforme se expõe abaixo:

- Prejudicado: quando não há elementos nos autos ou na decisão para afirmar a ocorrência ou não dos parâmetros indicados, seja pela indisponibilidade de visualização das peças processuais, seja porque não houve menção no acórdão de sua ocorrência. Em suma, quando houve dúvida sobre a juntada ou não da prova;

153 Alexy (2015, p. 619) afirma que os três níveis epistêmicos são passíveis de refinamento. Para o autor, o modelo triádico é dotado de plausabilidade intuitiva em relação ao escalonamento material. Esclarece, ainda, que nos casos de uma intervenção de alta intensidade deve ser exigida uma grande certeza das premissas empíricas que a sustentam. Os graus "prejudicado" ou "não comprovado" foram inseridos, no primeiro caso, porque por se tratar de pesquisa on line, nem todas as peças processuais estavam disponíveis em relação a algumas ações, inviabilizando qualquer afirmação sobre a comprovação ou não dos documentos que subsidiem os parâmetros analisados. No caso do critério "não comprovado", Robert Alexy não inclui essa possibilidade no modelo triádico, mas esta foi hipótese presente nos dados da pesquisa, considerando que a invocação do principio se deu em diversas ações, como mera alegação e despida de qualquer respaldo em prova documental de suas premissas. 
- Não comprovado: assinalado nas seguintes situações: a) quando os documentos necessários à comprovação do impacto orçamentário da prestação requerida ou de que não havia recursos suficientes para o atendimento da prestação requerida não foram juntados pela parte que alegou e b) quando a decisão proferida expressamente afirmou ou os documentos juntados comprovaram haver os recursos suficientes para o atendimento da prestação, sendo o contingenciamento (indisponibilidade) imotivado ou de motivação questionada pelos Ministros, convergindo a prova documental para o contrário da alegação de escassez fática de recursos;

- Não evidentemente falso: quando os documentos orçamentários foram juntados, mas foram considerados insuficientes na decisão para demonstrar o impacto orçamentário, a insuficiência do recurso ou a impossibilidade de utilização dos mecanismos de flexibilização;

- Plausível: quando houve a juntada de documentos orçamentários ou de parecer que indicasse de forma suficiente o impacto orçamentário da prestação pleiteada (escassez), mas que não comprovaram a impossibilidade de utilização dos mecanismos de flexibilização e a impossibilidade de auferir outros recursos para o custeio da prestação (intransponibilidade da escassez);

- Certo ou confiável: quando houve a juntada de documentos orçamentários suficientes para aferir o impacto orçamentário da prestação pleiteada, a insuficiência de recursos atual e futura e a impossibilidade de utilização de mecanismos de flexibilização ou de obtenção de receitas futuras para custear a prestação. Ou seja, quando foi comprovada de forma suficiente a escassez e a intransponibilidade dessa escassez de recursos.

No tocante à confiabilidade epistêmica normativa, o enquadramento em uma das cinco possibilidades acima descritas foi realizado a partir da análise da proximidade da prestação pleiteada com as prestações relativas ao mínimo existencial e da existência de precedentes judiciais ou decisões do Tribunal que dessem prevalência ao princípio da reserva do possível em relação ao princípio colidente na ação examinada, conforme se expõe abaixo:

- Prejudicado: assinalado quando: a) não havia elementos nos autos que possibilitassem verificar se a prestação requerida referia-se ou não conteúdo de mínimo existencial ou b) os Ministros não mencionaram se havia ou não precedentes que indicassem a prevalência de um ou outro princípio ou direito em colisão;

- Não comprovado: assinalado quando foi reconhecido na decisão que a prestação requerida estaria inserida no âmbito do mínimo existencial ou que havia precedente ou decisão anterior do Tribunal, adotada como paradigma, que indicou a prevalência do princípio ou direito 
colidente com o princípio da reserva do possível. Não sendo esta a situação constatada, a classificação foi estabelecida de acordo com os parâmetros a seguir.

- Não evidentemente falso: assinalado quando não houve indicaçãode precedente ou decisão do Tribunal que tivesse atribuído a prevalência ao princípio ou direito colidente.

- Plausível: assinalado quando houve indicação de decisão anterior do Tribunal, de natureza não vinculante, que atribuísse prevalência ao princípio da reserva do possível em relação ao colidente.

- Certo ou confiável: assinalado quando houve a indicação de precedente do Tribunal ou de súmula, de natureza vinculante, que atribuísse prevalência ao princípio da reserva do possível sobre o princípio colidente.

Com o objetivo de garantir o tratamento mais imparcial possível na análise dos parâmetros sugeridos, principalmente nos casos em que não foi possível o acesso a todos os dados do processo, não foi considerado o conceito doutrinário adotado pela pesquisa em relação aos institutos jurídicos do mínimo existencial e do núcleo essencial para aferir os parâmetros, mas o entendimento esboçado pelo próprio Tribunal. Assim, as respostas atribuídas às variáveis foram dadas a partir das afirmações dos Ministros em relação à situação da prestação pleiteada estar ou não inserida no conteúdo do mínimo existencial ou no núcleo essencial de um direito fundamental. De igual modo, foram tomadas como base as afirmações dos Ministros sobre a existência de precedentes ou de decisões anteriores do Tribunal, aplicáveis ao caso, reconhecidas pelo julgador.

Esclarecidos os procedimentos e os critérios de avaliação dos parâmetros passa-se à análise dos resultados.

\subsection{ANÁLISE DOS RESULTADOS}

Os resultados da frequência das ocorrências dos parâmetros de confiabilidade epistêmica empírica no STF e no STJ são ilustrados nos gráficos a seguir. Para melhor visualização, aos parâmetros de confiabilidade epistêmica empírica foram atribuídas letras para sua identificação, da seguinte forma: 
- A1 - Existência da prova documental que comprove o impacto orçamentário e/ou a inexistência ou insuficiência do crédito orçamentário para o atendimento da prestação do autor $^{154}$;

- A2 - Não observância de dever jurídico orçamentário em relação a despesas, que contribuiu para a insuficiência do recurso;

- A3 - Não observância de dever jurídico orçamentário em relação à receita, que contribuiu para a insuficiência do recurso;

- A4 - Impossibilidade normativa de utilização dos instrumentos de flexibilização orçamentária e da reserva de contingência para a despesa que o autor pleiteiava ${ }^{155}$.

Gráfico 1 - Parâmetros da confiabilidade epistêmica empírica - STF

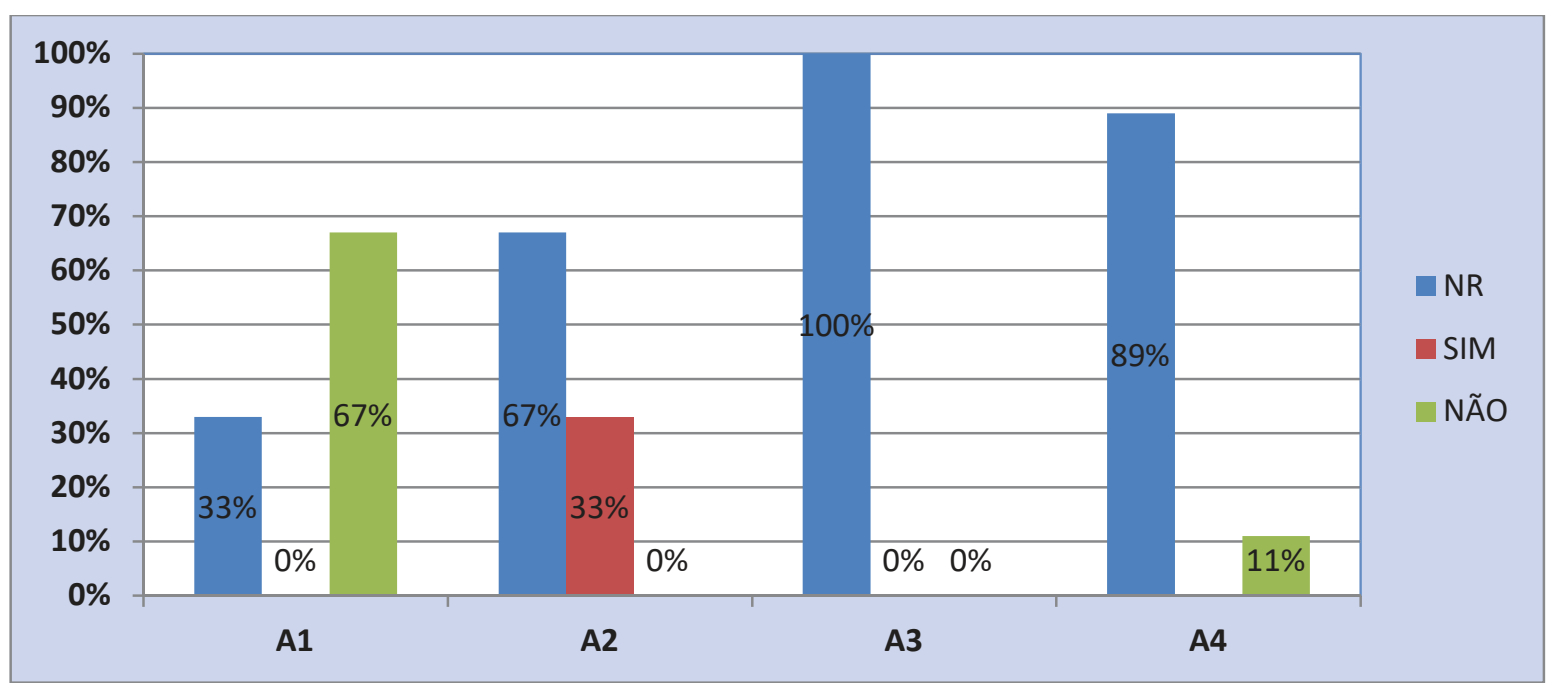

Fonte: elaborado pela autora (2021)

\footnotetext{
${ }^{154} \mathrm{O}$ atributo "NÃO" foi utilizado neste parâmetro quando não havia a prova documental da insuficiência do recurso público ou, quando apresentada, demonstrou efetivamente o contrário do que se alegou, ou seja, a existência de recursos suficientes para o custeio da prestação.

${ }^{155} \mathrm{O}$ atributo "NÃO" foi utilizado neste parâmetro quando na decisão era afirmada a possibilidade de se utilizar instrumentos de flexibilização orçamentária ou de reserva de contingência para o custeio da despesa que o autor pleiteava, o que se deu somente em 1 (um) caso analisado.
} 
Gráfico 2 - Parâmetros da confiabilidade epistêmica empírica - STJ

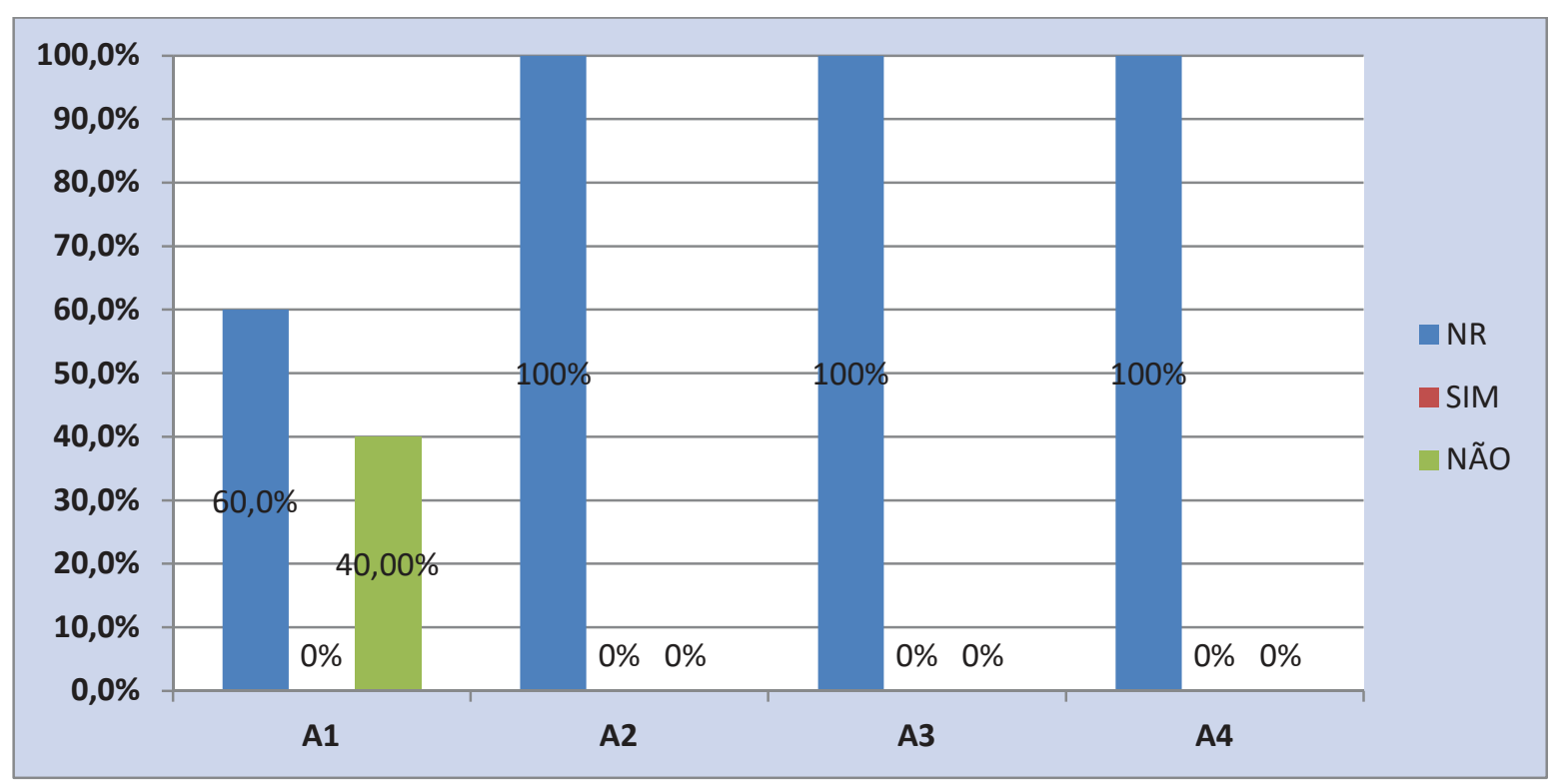

Fonte: elaborado pela autora (2021)

Um dos resultados que chama a atenção na presente pesquisa, por sua recorrência mais evidente, é a ausência da juntada de documentos comprobatórios do impacto orçamentário e/ou de documentos que comprovassem a inexistência ou insuficiência do crédito orçamentário para o atendimento da prestação relativa ao princípio de direito fundamental colidente. Esse evento ocorreu em 40\% das decisões analisadas no STJ e em 67\% das ações do STF. Nos demais casos, não foi possível aferir se houve ou não a juntada dos documentos, por não ter havido menção nas decisões dos processos em que os documentos probatórios estavam indisponíveis para visualização, o que resultou no prejuízo dessa verificação.

A despeito da importância das regras que tratam do ônus probatório das partes, a pesquisa empírica realizada demonstrou que somente em um número ínfimo de ações judiciais foi identificada a apresentação das leis orçamentárias ou de outro documento que pudesse comprovar o impacto orçamentário para fundamentar a impossibilidade de atendimento da prestação pleiteada pelo autor e sustentar a confiabilidade da premissa empírica. Esse dado chama a atenção porque os documentos que detalham a previsão e planejamento orçamentários - como o PPA, LDO e LOA -, quanto à execução orçamentária a exemplo do Relatório Resumido de Execução Orçamentária (RREO) -, são de elaboração obrigatória por parte dos entes públicos. E nos casos em que os documentos orçamentários foram juntados, o tribunal constatou que havia o recurso, mas que este estava sendo 
contingenciado de forma imotivada ou indevida. Essa ocorrência foi constatada nas seguintes ações: RE n. 592.581/RS e no RE n. 580.252/MS ${ }^{156}$.

Pode-se inferir que a ausência da prova documental da insuficiência de recurso constitui uma das variáveis que pode estar correlacionada diretamente com o não acolhimento do princípio da reserva do possível. E na presente pesquisa, esses dados apresentam relevância, ao se constatar que em ambos os tribunais, na totalidade dos casos, o princípio da reserva do possível não prevaleceu em relação ao princípio ou direito colidente.

Ainda, no âmbito do STJ, em 100\% dos casos analisados não houve menção à possibilidade de utilização de instrumentos de flexibilização orçamentária ou da regularidade ou não das alocações orçamentárias em relação à despesa ou à receita. De qualquer modo, em $40 \%$ dos casos essa análise ficaria prejudicada ante a ausência de qualquer prova documental que comprovasse a distribuição alocativa do orçamento ou a insuficiência efetiva dos recursos públicos.

No âmbito dos recursos especiais e extraordinários - nos quais o objeto central da lide são as questões de direito - a análise das questões de fato ocorre somente em situações excepcionais. Esta característica impede que o tribunal promova uma cognição probatória ampla e tais questões são tomadas a partir do que os tribunais e juízes locais decidiram sobre as questões de fato.

Portanto, é de fundamental importância que a prova da escassez de recursos e do impacto orçamentário seja devidamente analisada pelas instâncias inferiores, uma vez que é com base nessa cognição que os ministros do STF e do STJ fundamentarão suas decisões nos recursos extraordinário e especial que lhes são submetidos. Ou seja, a confiabilidade epistêmica empírica nestes casos está atrelada à escorreita apreciação das provas produzidas nas instâncias inferiores, evidenciando a importância do conhecimento, por parte desses magistrados, das premissas empíricas subjacentes ao princípio da reserva do possível. Assim, reforça-se a importância da identificação de parâmetros objetivos para auxiliar tanto juízes quanto tribunais no procedimento da ponderação, principalmente no tocante à análise das provas e da confiabilidade epistêmica das premissas empíricas invocadas, quando o princípio da reserva do possível é alegado.

\footnotetext{
${ }^{156}$ A mesma ocorrência foi constatada na apreciação da tutela liminar requerida na ADPF n. 347/DF, a qual não foi computada por se tratar de decisão interlocutória e que pode ser reformada.
} 
Em relação à confiabilidade epistêmica normativa, foram definidos dois parâmetros para sua análise. Para melhor visualização no gráfico, aos parâmetros de confiabilidade epistêmica empírica foram atribuídas letras para sua identificação, da seguinte forma:

- B1- A alegação de insuficiência de recursos obsta prestações relativas ao mínimo existencial;

- B2 - Existência de acórdão do Tribunal ou precedente judicial que tenha estabelecido precedência do princípio da reserva do possível, nas mesmas condições, em relação ao mesmo princípio colidente ${ }^{157}$.

Os gráficos a seguir ilustram o nível de ocorrência dos parâmetros de confiabilidade epistêmica normativa, em ambos os tribunais.

Gráfico 3 - Parâmetros de confiabilidade epistêmica normativa - STF

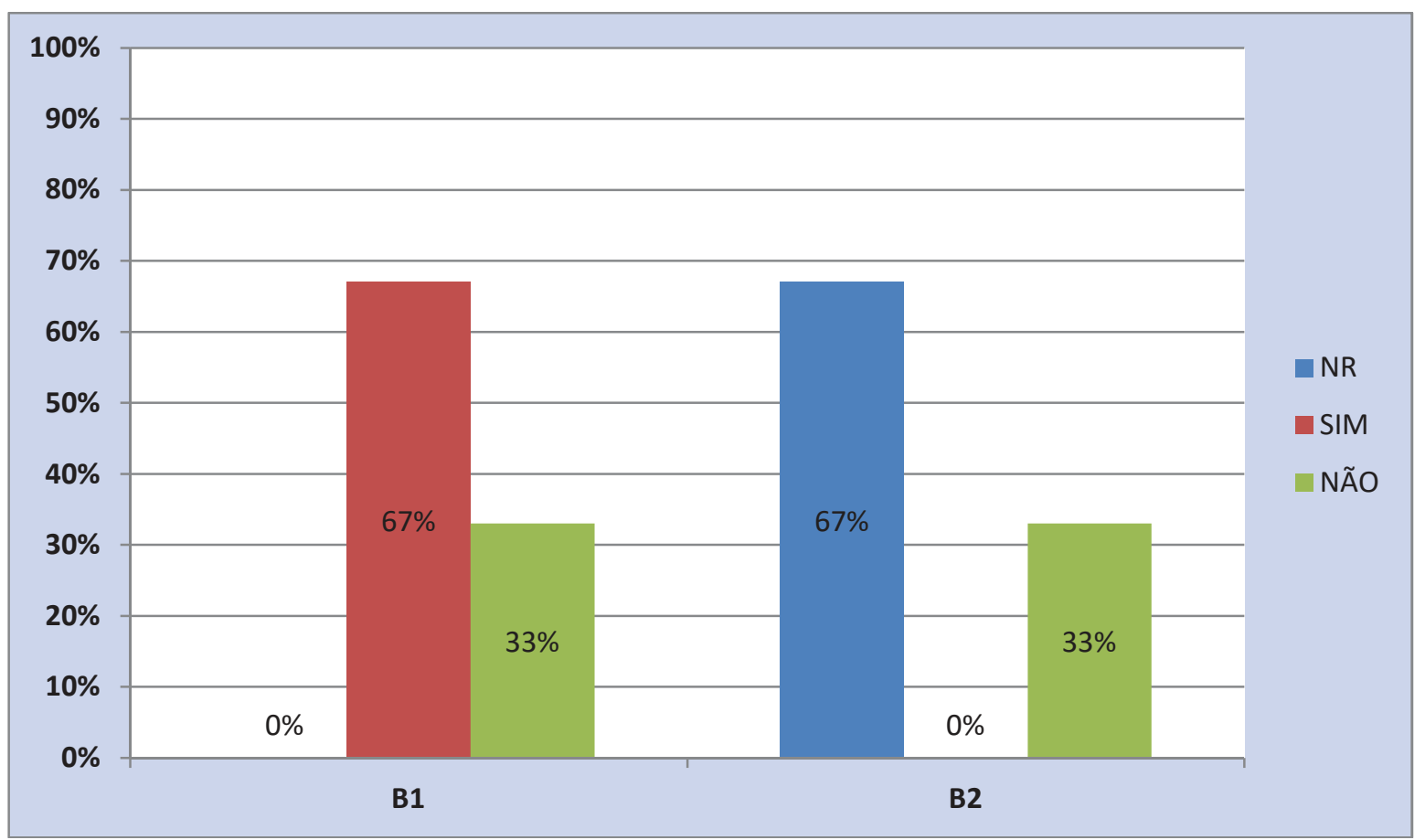

Fonte: elaborado pela autora (2021)

No caso dos parâmetros de confiabilidade das premissas normativas, no âmbito do STF, em $67 \%$ dos casos, a prestação pleiteada inseria-se no conteúdo do mínimo existencial

157 O atributo "NÃO" foi utilizado quando foi citado de acórdão do Tribunal ou precedente judicial que tenha estabelecido precedência do princípio colidente, nas mesmas condições, em relação princípio da reserva do possível. O atributo "NR" foi utilizado quando não havia referências a de acórdão do Tribunal ou precedente judicial que tenha estabelecido precedência do princípio da reserva do possível ou do princípio colidente. 
(de acordo com o entendimento do tribunal sobre quais prestações compõem o mínimo existencial), o que ocasionou a preterição do princípio da reserva do possível nesses processos. No tocante à verificação da citação de precedentes judiciais que davam prevalência ao principio da reserva do possível, verificou-se que essa situação não ocorreu em nenhuma decisão. Constatou-se, ainda, que em $67 \%$ dos casos fundamenta a decisão em acórdãos que dão prevalência ao princípio colidente, mas este princípio ou direito fundamental não se identifica com o princípio ou direito colidente no caso concreto. Nessa situação, inclui-se os acórdãos em que o tribunal enquadrou o direito colidente nas prestações do mínimo existencial e invocou precedentes sobre a prevalência do mínimo existencial sobre o princípio da reserva do possível, mas o julgado tratava de outros direitos ou princípios de direito fundamental. Nestes casos, foi atribuído o valor "NR" à confiabilidade epistêmica do principio da reserva do possível em relação ao critério de existência de precedente. $\mathrm{O}$ percentual de precedentes invocados que não reconhecem a prevalência do princípio da reserva do possível, mas a prevalência do mesmo princípio colidente no caso analisado, perfaz o montante de $33 \%$ dos acórdãos.

Desses resultados, extrai-se que, nos acórdãos analisados, não se pode identificar qualquer regra extraída de precedente judicial que esteja se consolidando na jurisprudência pátria, em relação à prevalência do princípio da reserva do possível sobre um principio colidente. Desse fato, infere-se que a confiabilidade epistêmica da premissa normativa em que se basearam as decisões do STF é reduzida em relação à aplicação do princípio da reserva do possível, uma vez que ainda não se estabeleceu regra jurídica para a sua prevalência e que sirva de parâmetro para casos futuros.

O quadro a seguir demonstra o apurado no âmbito do STJ em relação aos parâmetros de confiabilidade epistêmica normativa: 
Gráfico 4 - Parâmetros de confiabilidade epistêmica normativa - STJ

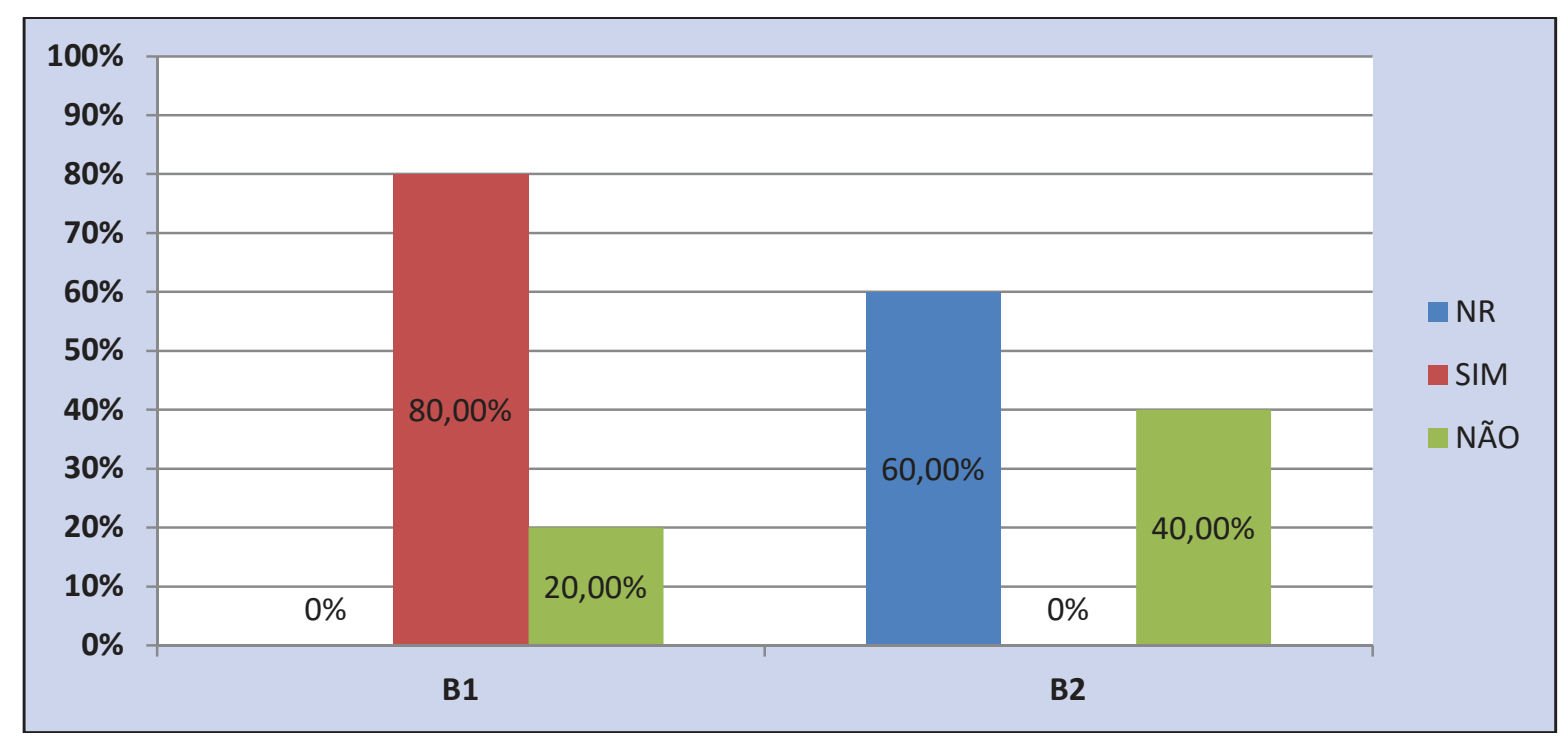

Fonte: elaborado pela autora (2021)

No âmbito do STJ esses percentuais apresentam-se pouco diferenciados. A maior distinção se deu em relação à frequência da alegação do princípio da reserva do possível em contraposição à efetivação de prestações inseridas no conteúdo do mínimo existencial, que totalizou $80 \%$ dos casos. Por sua vez, foi apurado que $40 \%$ das decisões citavam precedentes que atribuíam expressamente a prevalência do princípio ou direito colidente. Em $60 \%$ dos casos, os precedentes citados não tratavam da prevalência do princípio da reserva do possível para fundamentar a decisão adotada pelo Tribunal, ou a invocação do precedente no processo analisado se deu para afirmar outros direitos que não especificamente aqueles que colidiam com princípio da reserva do possível. Da mesma forma que no âmbito do STF, nessa situação foram incluídos os casos em que o tribunal enquadrou o direito colidente nas prestações do mínimo existencial e invocou precedentes sobre a prevalência do mínimo existencial sobre o princípio da reserva do possível, mas o julgado tratava de outros direitos ou normas de direito fundamental que não aquele colidente no caso concreto. Essas ocorrências fizeram aumentar os casos em que o valor "NR" foi atribuído à confiabilidade epistêmica do princípio da reserva do possível em relação ao critério de existência de precedente.

A partir da análise conjunta dos resultados atribuídos à ocorrência dos parâmetros de confiabilidade epistêmica empírica e normativa em cada tribunal, procedeu-se à elaboração da distribuição dos níveis ou graus constatados à confiabilidade epistêmica das premissas empíricas e normativas, o que resultou nos gráficos abaixo: 
Gráfico 5 - Graus de confiabilidade epistêmica sugeridos - STF

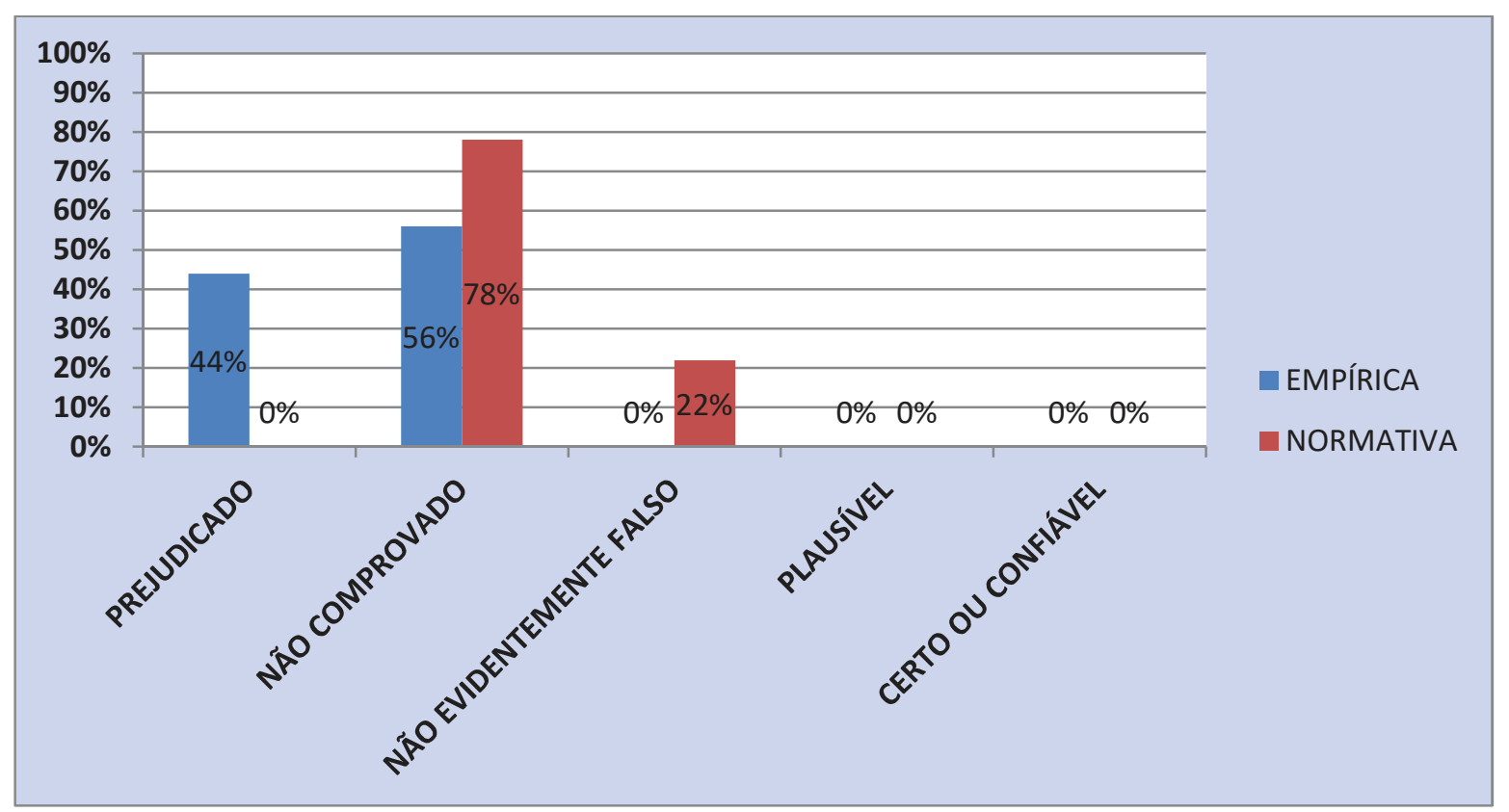

Fonte: elaborado pela autora (2021)

Gráfico 6 - Graus de confiabilidade epistêmica sugeridos - STJ

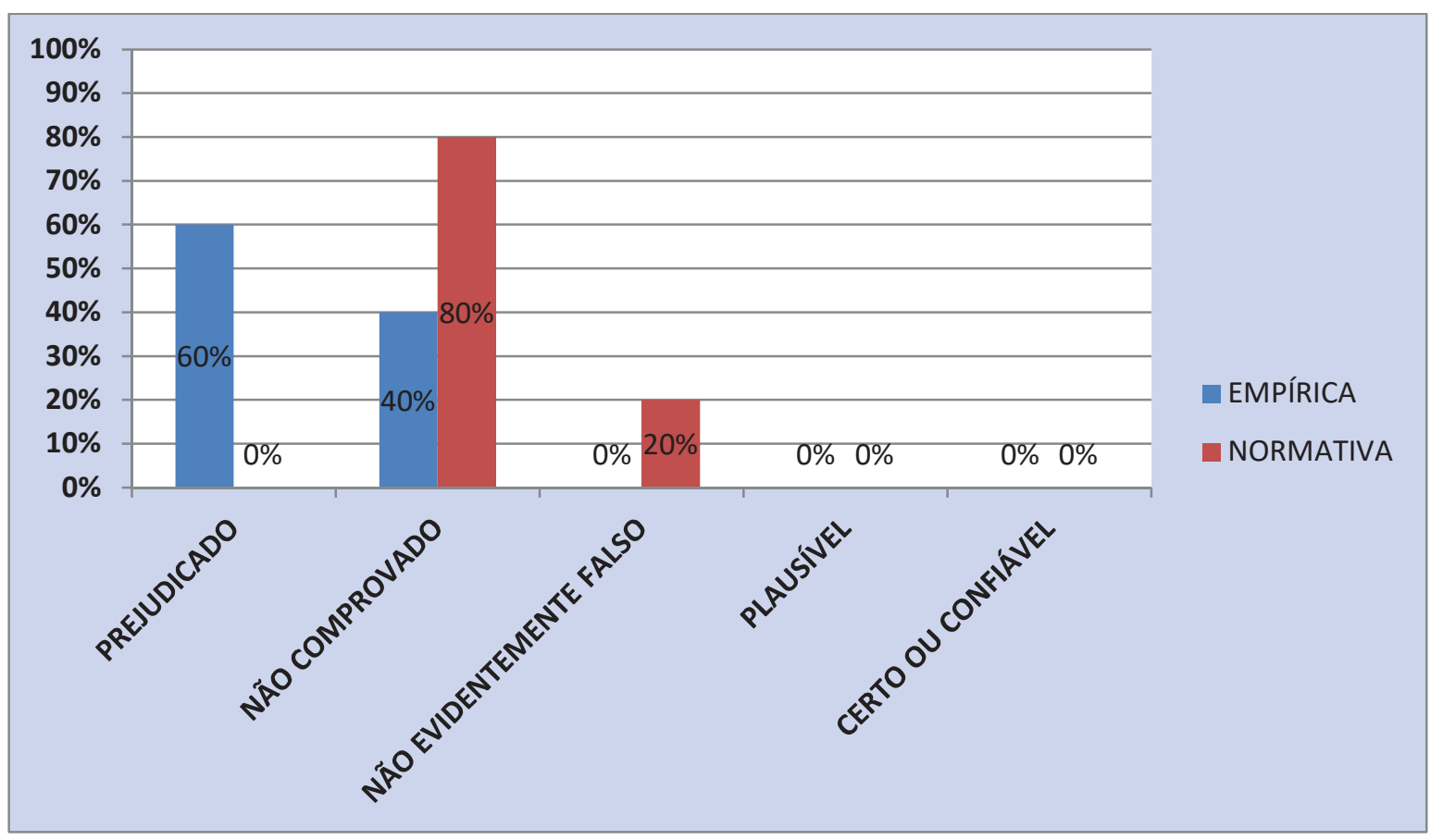

Fonte: elaborado pela própria autora (2021)

O primeiro gráfico demonstra que em $56 \%$ nos acórdãos do STF a confiabilidade epistêmica empírica não está assentada em bases documentalmente comprovadas e em 44\% 
dos casos foi considerada prejudicada essa análise por não haver referência à juntada destes documentos. No caso do STJ, em 40\% dos casos a confiabilidade epistêmica empírica não estava assentada em fundamentos comprovados e em $60 \%$ dos casos, a comprovação foi considerada prejudicada. Disso resulta que a alegação de ofensa ao princípio da reserva do possível feita pelo órgão estatal que figurava como demandado da prestação estatal positiva, sem a respectiva juntada de documentos probatórios da alegação, prejudica a confiabilidade da premissa empírica subjacente ao princípio da reserva do possível e pode indicar que a esse princípio vem sendo atribuído um tratamento meramente retórico, uma vez que se trata de alegação sem o respaldo em razões baseadas em premissas empíricas confiáveis.

Da compilação da distribuição dos parâmetros no STF resultou que a confiabilidade epistêmica normativa não foi comprovada em $78 \%$ dos casos; em $22 \%$, foi enquadrada como não evidentemente falso. Já no âmbito do STJ, da análise da ocorrência desses parâmetros resultou que, em $20 \%$ dos casos analisados, o grau de confiabilidade epistêmica normativa foi classificado como não evidentemente falso e em $80 \%$ dos casos foram classificados como não comprovado. Em nenhum dos tribunais houve a classificação da confiabilidade epistêmica empírica ou normativa como plausível ou confiável. Constata-se a proximidade nos resultados dos parâmetros em cada tribunal em relação à confiabilidade das premissas normativas.

Considerando que o objeto da pesquisa é o tratamento destinado ao princípio da reserva do possível pelos tribunais selecionados independentemente de qual seja o princípio ou interesse com ele colidente, observou-se que, no âmbito do STJ, na maioria das ações em que o princípio da reserva do possível foi alegado, a norma em oposição a esse princípio não veiculava um princípio de direito fundamental, mas um direito líquido e certo à reparação econômica retroativa de anistiados políticos. Isso contribuiu para que, em poucas ações, as prestações relativas ao mínimo existencial fossem discutidas em oposição ao princípio da reserva do possível.

Nos gráficos acima, pode-se verificar que não houve atribuição dos graus confiável ou plausível para a confiabilidade epistêmica empírica e normativa em nenhuma das decisões de ambos os tribunais. A partir desse dado, pode-se concluir que, quando se trata de ações em que o princípio da reserva do possível é invocado, tanto o STF quanto o STJ têm fundamentado seus acórdãos com base em razões cujas premissas relativas à incidência do princípio da reserva do possível possuem graus de confiabilidade relativamente baixos. Essa constatação é preocupante, especialmente pelo fato de que as asserções feitas em juízo devem ser comprovadas pelas partes, bem como devem ser fundamentadas. Nem provas, nem razões 
assentadas em bases confiáveis, são trazidas aos autos, uma vez que a prova documental da insuficiência de recursos não foi apresentada.

Não obstante, nos acórdãos analisados do âmbito do STF esse risco acabou por ser afastado porque em nenhuma das ações o princípio da reserva do possível prevaleceu, demonstrando o correto tratamento pelos Ministros no tocante às regras processuais de distribuição do ônus da prova, bem como a preocupação inserida no entendimento destas cortes em se garantir a proteção do mínimo existencial e de direitos líquidos e certos contra omissões estatais desprovidas de justificação suficiente e racional. No STJ houve uma única decisão compilada no ano de $2019^{158}$ em que o direito pleiteado não prevaleceu. A ação tratava-se de recurso em Mandado de Segurança e o objeto versava sobre a impugnação de ato de juiz-auditor que determinava a designação de Defensor Público para exercer atribuições perante o juízo-auditor dos Conselhos de Justiça Militar do Distrito Federal e patrocinar os interesses de acusados (bombeiros e policiais militares) nos autos dos processos em trâmite perante o Juízo presidido pela autoridade apontada como coatora. Neste caso, a decisão reconheceu a inexistência de profissionais concursados em número suficiente para atender toda a população do DF, e considerou razoáveis os critérios indicados pelo Conselho Superior da Defensoria Pública do DF para a alocação e distribuição dos Defensores Públicos (locais de maior concentração populacional e de maior demanda, faixa salarial familiar até cinco salários mínimos, consideradas as limitações orçamentárias daquele órgão (BRASIL, STJ, RMS 59.413/DF, 2019). Contudo, a decisão não indicou que tenha havido a apresentação de estudos ou de relatórios orçamentários que pudessem subsidiar tais conclusões, prejudicando a valoração do grau de confiabilidade da premissa empírica.

Trivisonno (2018, p. 39) afirma que quanto maior a certeza das premissas empíricas e normativas referentes à lesão a um direito fundamental mais se justifica a atuação da corte constitucional. A pesquisa constata que os princípios de direitos fundamentais têm sido massivamente preponderantes sobre o princípio da reserva do possível nas decisões analisadas. Entretanto, esse entendimento quase unitário e uniforme de ambos os tribunais superiores brasileiros STF e STJ não decorre de efetiva demonstração por provas trazidas aos

\footnotetext{
158 A decisão não foi computada uma vez que o principal fundamento do indeferimento do pedido foi o fato de que "a Emenda Constitucional n ${ }^{\circ}$ 80, de 4/6/2014, conferiu nova redação ao art. 98 do Ato das Disposições Constitucionais Transitórias estabelecendo um prazo de 8 (oito) para instalação de serviços mínimos prestados pela Defensoria, que se esgota em 2022. Por esse motivo, a jurisprudência do STF tem entendido que a exigibilidade de atendimento integral da população pela Defensoria Pública está condicionada ao transcurso do prazo estabelecido na EC 80/2014", bem como da interferência na autonomia funcional e administrativa constitucionalmente asseguradas à Defensoria Pública. (BRASIL, STJ, RMS 59.413/DF, 2019, p. 3-4).
} 
autos ou de detida análise do maior grau de confiabilidade epistêmica empírica e normativa dos princípios de direitos fundamentais em relação à confiabilidade epistêmica empírica e normativa do princípio da reserva do possível, a partir da utilização de claros e objetivos parâmetros de mensuração daquela confiabilidade. Embora esteja comprovada a baixa confiabilidade epistêmica empírica e normativa do principio da reserva do possível, as decisões não adentram na consideração destas variáveis de forma explícita na ponderação do principio da reserva do possível. 


\section{CONCLUSÃO}

O objetivo da presente pesquisa foi aferir cientificamente se as decisões das cortes superiores brasileiras (STF e STJ), nas ações em que o princípio da reserva do possível é invocado pelo Poder Público, têm sido proferidas com fundamento em premissas suficientemente comprovadas e com grau de confiabilidade epistêmica empírica e normativa suficiente para justificar adequadamente intervenções em direitos fundamentais.

A resposta ao problema proposto demandou a busca de parâmetros objetivos para subsidiar a análise de tal confiabilidade epistêmica empírica e normativa das premissas subjacentes ao princípio da reserva do possível e que pudessem auxiliar o intérprete a efetuar racionalmente a aplicação desse princípio quando em colisão com princípios de direitos fundamentais. Isso porque, tanto na doutrina, quanto na jurisprudência, referidos parâmetros ainda não estavam devidamente aclarados, pela diversidade de tratamento do princípio da reserva do possível como uma "condição da realidade", como postulado, como causa de exclusão de ilicitude.

Fez-se necessário o desenvolvimento da dissertação em duas partes: a primeira, referente à pesquisa teórico-bibliográfica e a segunda, à pesquisa empírico-documental.

Na primeira parte, verificou-se que o princípio da reserva do possível não possui tratamento uniforme, nem na doutrina, nem na jurisprudência brasileiras. Constatou-se que, na abordagem pátria, foi dada ênfase ao aspecto da escassez de recursos (dimensão fática), ao contrário da concepção originária do direito alemão, que enfatiza a razoabilidade da pretensão do particular em face do Estado. Assim, primeiramente, foi necessária a elaboração de um conceito adequado do princípio da reserva do possível, que delimitasse sua natureza jurídica e possibilitasse a coerência de sua aplicação pelos tribunais, mitigando possíveis distorções no seu tratamento. Nesta fase, a elaboração conceitual do princípio da reserva do possível trouxe a delimitação de sua natureza como princípio jurídico material, cujo objeto de otimização se refere a um determinado conteúdo, especificamente, à razoabilidade de uma pretensão positiva material frente ao Estado tendo como parâmetro limitador dessa pretensão as possibilidades fáticas decorrentes de alocações orçamentárias que também se deve exigir que sejam razoáveis, de acordo com o explicitado no primeiro capítulo.

A seguir, foi analisada a relação do princípio da reserva do possível com as normas de direitos fundamentais, concluindo que esse princípio pode constituir razão para a restrição do 
conteúdo das normas de direitos fundamentais, em suas posições prima facie, limitando-lhes as possibilidades jurídicas em situações concretamente analisadas pelos tribunais. Ao mesmo tempo, o princípio da reserva do possível sofre restrições em seu âmbito de aplicação, tendo sido identificados os seguintes: a) o direito ao mínimo existencial; b) a proteção do núcleo essencial e demais posições definitivas reconhecidas por precedentes judiciais ou por decisões com efeitos vinculantes; c) o princípio da máxima aplicação dos recursos disponíveis. Restou ainda demonstrado que não somente os direitos fundamentais sociais demandam a destinação de recursos públicos à sua efetivação. Assim, afastar uma possível colisão do princípio da reserva do possível, ab initio, no caso de normas de direitos fundamentais individuais, que também demandam ações positivas estatais, significaria o estabelecimento de uma prioridade orçamentária não constitucionalmente autorizada - pois as futuras pretensões positivas assecuratórias de direitos individuais estariam excluídas da exigência de ponderação e da razoabilidade que o princípio da reserva do possível determina às pretensões individuais. Essa situação deixa então clara a improcedência ou falsidade do argumento de que somente os direitos fundamentais sociais entrariam em colisão com o princípio da reserva do possível, em razão de serem mais "custosos” aos cofres públicos.

Revisitando a doutrina pátria, que apregoa a existência de dimensões do princípio da reserva do possível, foi analisada que a dimensão fática - atribuída à inexistência real de recursos para o atendimento às prestações de direitos fundamentais - e a dimensão jurídica que se relaciona à indisponibilidade de recursos em razão de decisões alocativas orçamentárias - tratam especificamente de um aspecto que envolve o tema do princípio da reserva do possível: a escassez.

Extrai-se que a escassez de recursos públicos constitui uma premissa empírica subjacente à aplicação do princípio da reserva do possível e que limita as possibilidades fáticas ao cumprimento de uma prestação positiva de direito fundamental protegida por uma norma principiológica constitucional colidente. A limitação de recursos públicos em determinado exercício orçamentário pode constituir um limite para a verificação da medida de razoabilidade da pretensão de obtenção de prestações materiais em face do Estado. Ao mesmo tempo, a existência de escassez de recursos impõe a razoabilidade na alocação dos recursos públicos, cuja ideia regulativa consiste na priorização da concretização dos direitos fundamentais sobre outros interesses. Isso porque não se poderia recusar o atendimento a prestações devidas e razoáveis com base em limitações impostas por um orçamento elaborado de forma desarrazoada e eivado de vícios. 
No tocante à escassez e suas dimensões, demonstrou-se que o Estado possui inúmeros instrumentos de obtenção de recursos para a concretização de suas finalidades e que, em alguns casos, esses instrumentos não têm sido adequadamente utilizados. As opções políticas que dão ênfase à obtenção de recursos mediante tributação regressiva e do financiamento junto ao setor privado (aliada às políticas de austeridade fiscal) têm minado as possibilidades estatais de obtenção de receitas suficientes para o atendimento, em maior extensão, das prestações de direitos fundamentais. Assim, a doutrina tem reconhecido que a questão da escassez é menos provocada por questões fáticas e econômicas e mais por opções políticas dos governantes.

Percebeu-se ainda que, quando se trata da análise do princípio da reserva do possível, em sua dimensão fática, as premissas emprestadas da teoria econômica para fundamentar a análise jurídica do instituto não são devidamente aclaradas nas decisões judiciais e nem na doutrina. E, a depender da teoria econômica adotada, as conclusões jurídicas podem se apresentar em sentidos diversos, pois partem de premissas, por vezes, contrapostas. A imposição e naturalização das premissas de teorias econômicas pragmáticas, de vertente neoliberal, sobre a teoria jurídica, especialmente, sobre a teoria dos direitos fundamentais, podem acarretar distorções em relação à análise jurídica da efetividade das normas constitucionais que asseguram esses direitos, pela sobreposição da dimensão econômica sobre o jurídico. Ao pesquisador, inclusive no Direito, incumbe evitar a naturalização dos conceitos econômicos sem uma compreensão mínima das premissas que fundamentam sua análise, uma vez que cada teoria econômica traz subjacente um determinado modelo de Estado que, em alguns casos, pode não coadunar com o modelo inserido em nossa Constituição. A dimensão fática da escassez é quase impossível de ser devidamente aferida, na concepção de um real esgotamento das possibilidades estatais de satisfação da pretensão do requerente, porque o estabelecimento desses limites vai depender da teoria econômica adotada para a avaliação das possibilidades estatais de forma técnica e não ideologizada.

Emerge, pois, que a escassez dos recursos econômicos destinados à realização dos direitos fundamentais é fundamentalmente determinada pela escolha alocativa realizada pelos poderes públicos. Disso decorre que a escassez de recursos públicos - quando alegada pelo Poder Público como obstáculo à efetivação de um direito fundamental pleiteado em juízo não é algo que deva ser tratado como uma presunção jurídica (eis que não há norma jurídica que autorize ou determine tal presunção legal) ou como fato notório ou autoevidente. Trata-se de fato alegado por uma das partes, que exige prova judicial de sua ocorrência e extensão de 
acordo com a lei processual.

Demonstrou-se, ainda, que em alguns casos a indisponibilidade de recursos públicos se dá em razão de uma decisão unilateral do Poder Executivo, que obsta a aplicação das verbas públicas destinadas pelo Poder Legislativo a certas áreas, na forma de contingenciamento de despesas. Assim, passou-se à discussão sobre a vinculatividade do Poder Executivo em relação ao aprovado pelas leis orçamentárias. Verificou-se que após a edição da Emenda Constitucional n 100/2019, há incompatibilidade em se defender o caráter meramente autorizativo das leis orçamentárias, ainda mais por se tratar de norma jurídica veiculada por regra constitucional, cujas exceções foram devidamente explicitadas no texto constitucional. Contudo, essa vinculatividade deve ser interpretada em conjunto com as normas que permitem, em determinadas circunstâncias, a flexibilização do orçamento durante sua execução, que em regra, demanda nova autorização legislativa.

Um ponto de grande relevância envolvendo o tema da reserva do possível é a possibilidade de desvios de poder na elaboração e na execução orçamentárias. Esses desvios constituem óbices para se aferirem adequadamente as efetivas e legítimas limitações estatais para o atendimento às prestações de direitos fundamentais. A existência de desvios de poder e vícios orçamentários impedem o estabelecimento de um parâmetro racional para a aferição da razoabilidade de pretensão individual ou de razoabilidade das alocações orçamentárias, porque acaba submetendo o julgador à avaliação de uma peça orçamentária fíctícia e eivada de ilegalidades.

A busca por um tratamento mais racional na abordagem do princípio da reserva do possível, quando em colisão com normas de direitos fundamentais, exigiu a adoção de um fundamento teórico sólido e sistêmico, como o fornecido pela obra de Robert Alexy, marco teórico dessa investigação. Com base nos fundamentos da Teoria da Argumentação Jurídica, Teoria dos Direitos Fundamentais e da Teoria dos Princípios pelo autor elaborada, realizou-se o levantamento de parâmetros que pudessem ser utilizados na denominada fórmula do peso refinada, a qual considera, na ponderação de princípios, não somente os pesos das intervenções e o grau de importância de satisfação dos princípios em colisão, mas também a medida da qualidade epistêmica com base na qual os pesos dessas intervenções são avaliados.

Dessa análise, resultou a identificação de alguns parâmetros para a aferição da confiabilidade epistêmica tanto das premissas empíricas e normativas do princípio da reserva do possível. No primeiro caso, elegeram-se os seguintes parâmetros: a) existência de prova documental suficiente à comprovação do impacto orçamentário e/ou da inexistência ou da 
insuficiência do crédito orçamentário para o atendimento da prestação do autor; b) inobservância ou não de dever jurídico orçamentário que contribuiu para a insuficiência do recurso; c) impossibilidade normativa de utilização dos instrumentos de flexibilização orçamentária (como créditos especiais, créditos suplementares, transposição e remanejamentos) e da reserva de contingência para a despesa que o autor pleiteia.

Quanto aos parâmetros para análise do grau de confiabilidade epistêmica normativa, optou-se pela consideração daqueles que pudessem indicar o grau de confiabilidade da premissa normativa a partir da exclusão de conteúdos constitucionalmente impossíveis ou conteúdos proibidos e de conteúdos constitucionalmente necessários para a prevalência do princípio da reserva do possível. Isso porque consideração a priori de todas as restrições e interferências impostas por cada princípio potencialmente colidentes ao princípio da reserva do possível e de suas possíveis premissas, deveria ser feita caso a caso, de acordo com as especificidades jurídicas do conteúdo prima facie de cada norma principiológica colidente, o que seria tarefa inatingível no âmbito desta pesquisa. Assim, foram selecionados os seguintes parâmetros para a análise da confiabilidade epistêmica normativa: a) se a invocação do princípio se deu frente a prestações relativas ao mínimo existencial; b) se havia decisão vinculante anterior do Tribunal ou precedente que tenha estabelecido regra de precedência do princípio da reserva do possível, nas mesmas condições, em relação ao mesmo princípio colidente.

Eleitos os parâmetros, passou-se à investigação empírica das decisões do STF e do STJ a partir do marco temporal inicial de 01/01/2010. O recorte temporal foi escolhido por corresponder à instrumentalização dos processos eletrônicos nos tribunais indicados, permitindo a consulta das decisões e das peças processuais. Estabeleceram-se critérios de descarte de decisões, principalmente com vista a preservar a análise de decisões definitivas e colegiadas.

Quantificando a ocorrência desses parâmetros nas decisões, observou-se ao final, que em nenhuma das decisões analisadas o princípio da reserva do possível prevaleceu. Foi constatado, ainda, que na maioria dos casos não houve qualquer comprovação documental que corroborasse a invocação do princípio por parte do Poder Público.

Conclui-se que a problemática da aplicação do princípio da reserva do possível se inicia na diversidade de sua conceituação, o que acarreta tratamentos diferenciados do instituto jurídico pelos tribunais e pela doutrina. Mas, dramática, é a constatação de que, muito embora constantemente invocado pelo Poder Público como argumento de defesa nas 
ações em que figura como demandado, a comprovação dos fatos e premissas invocadas para a aplicação do princípio não têm sido devidamente efetivada. E isso tem ocorrido, muito embora os documentos probatórios destinados a comprovação da premissa empírica da escassez de recursos públicos (como as leis orçamentárias, demonstrativos e anexos) sejam de elaboração obrigatória pelo ente Estatal e deveriam estar disponíveis ao Poder Judiciário no momento da cognição judicial da ponderação do princípio da reserva do possível. Esse fato tente a promover uma distorção na tutela dos direitos fundamentais assegurados na Constituição de 1988. Isso porque a insuficiência na comprovação das premissas que autorizam a aplicação do princípio da reserva do possível leva o Judiciário a proferir decisões baseadas em argumentos com baixo grau de confiabilidade epistêmica, aumentando a zona de incerteza quanto à racionalidade e objetividade dos fundamentos de tais decisões. Assim, compromete-se a segurança jurídica, o controle do subjetivismo das decisões, a isonomia, impedindo a adequada tutela dos direitos fundamentais, valores prestigiados no Estado Democrático de Direito.

A utilização da técnica da ponderação pode ser aprimorada a partir da identificação de parâmetros objetivos para se aferir a confiabilidade das premissas empíricas e normativas subjacentes ao princípio da reserva do possível. Esses parâmetros possibilitam orientar, com maior correção e racionalidade a fundamentação das decisões que envolvam esse princípio. É, portanto, medida necessária para que a utilização do princípio da reserva do possível não seja banalizada por sua invocação erística, sustentada em presunções não autorizadas em lei, de forma a contribuir para que as decisões possam oferecer uma fundamentação mais objetiva e consistente, baseadas em premissas confiáveis, inibindo intervenções indevidas em um direito. Por outro lado, também pode evitar que o princípio da reserva do possível seja preterido sem a devida fundamentação argumentativa que deve justificar a não prevalência de qualquer princípio jurídico, especialmente aqueles assegurados em âmbito constitucional. Inegavelmente, não há pretensão neste trabalho de esgotar o tema, mas de contribuir, em alguma medida, para o avanço do debate acadêmico no tocante à identificação dos parâmetros mínimos para assegurar a confiabilidade das premissas em que se fundamentam as decisões dos tribunais brasileiros que aplicam o princípio da reserva do possível, possibilitando auxiliar o seu adequado tratamento jurídico. 


\section{REFERÊNCIAS}

ABRAHAM, Marcus. O controle de constitucionalidade das leis orçamentárias. GEN Jurídico, fev., 2017. Disponível em: http://genjuridico.com.br/2017/02/21/o-controle-deconstitucionalidade-das-leis-orcamentarias. Acesso em: 29 dez. 2020.

ABRAHAM, Marcus. Sobre a Emenda Constitucional $n^{\circ}$ 100: a certeza da impositividade orçamentária. GEN Jurídico. 2019. Disponível em:

https://genjuridico.jusbrasil.com.br/artigos/730468230/sobre-a-emenda-constitucional-n-100a-certeza-da-impositividade-orcamentaria. Acesso em: 10 mar. 2020.

ALEMANHA. Tribunal Constitucional Federal (BVerfG). 1 BvL 20/84. j. 29.05.1990.

BVerfGE 82, 60. NJW 1990, 2869. Disponível em: https://servat.unibe.ch/dfr/bv082060.html. Acesso em: 29 set. 2020.

ALEMANHA, Tribunal Constitucional Federal (BVerfG). 1 BvL 51/86 e 50/87; 1 BvR 873/90, 761/91. j. 07.07.1992. BVerfGE 87, 1. NJW 1992, 2213. Disponível em: https://www.servat.unibe.ch/dfr/bv087001.html. Acesso em 29 set. 2020.

ALEMANHA. Tribunal Constitucional Federal (BVerfG). 1 BvR 178-97. j. 10.03.1998. BVerfGE 97, 332. NJW 1998, 2128. Disponível em:

https://servat.unibe.ch/dfr/bv097332.htm. Acesso em: 29 set. 2020.

ALEMANHA. Tribunal Constitucional Federal (BVerfG). 1 BvR 1629/94.d. j. 3 abr. 2001. BVerfGE 103, 242. NJW 2001, 1712. Disponível em: https://www.servat.unibe.ch/dfr/bv103242.html. Acesso em: 29 set. 2020.

ALEMANHA. Tribunal Constitucional Federal (BVerfG). 1 BvR 684/98. j. 09.11.2004. BVerfGE 112, 50. NJW 2005, 1413. Disponível em: https://www.servat.unibe.ch/dfr/bv112050.html. Acesso em: 29 set. 2020.

ALEXY, Robert. Teoria dos Direitos Fundamentais. Tradução: Virgílio Afonso da Silva. $2^{\text {a }}$ ed., $4^{\mathrm{a}}$ tiragem. São Paulo: Malheiros, 2015.

ALEXY, Robert. A dignidade humana e a análise da proporcionalidade. In: ALEXY, Robert; BAEZ, Narciso Leandro Xavier; SILVA, Rogério Luiz Nery da (org.). Dignidade humana, direitos sociais e não-positivismo inclusivo. Florianópolis: Qualis, p.13-38, 2015.

ALEXY, Robert. Princípios Formais. In: TRIVISONNO, Alexandre Travessoni Gomes; SALIBA, Aziz Tuffi; LOPES, Mônica Sette (org.). Princípios formais e outros aspectos da teoria discursiva do direito/ Robert Alexy. $2^{\mathrm{a}}$ ed. Rio de Janeiro: Forense, p. 3-25, 2018.

ALVES JÚNIOR, Luís Carlos Martins; SAMPAIO, Alexandre Santos. Parâmetros de atuação do Poder Judiciário nas políticas públicas. A\&C - Revista de Direito Administrativo \& Constitucional. Belo Horizonte, ano 18, n. 74, p. 217-245, out./dez. 2018.

BAPTISTA, Antônio Luis Silva; SILVA, Carolina de Freitas. O tratamento das omissões inconstitucionais no âmbito dos direitos fundamentais sociais em Portugal e no Brasil.In: 
Revista da Faculdade de Direito da Universidade de Lisboa - RFDUL/LLR, v. LVIX, p.193-234, 2018.

BERCOVICI, Gilberto; MASSONETTO, Luís Fernando. A constituição dirigente invertida: a blindagem da Constituição Financeira e a agoniada Constituição Econômica. Boletim de Ciências Econômicas, v. XLIX. Coimbra: Impactum.uc.pt., p.57-77, 2006.

BARCELLOS, Ana Paula de. A eficácia jurídica dos princípios constitucionais: o princípio da dignidade da pessoa humana. Rio de Janeiro, Renovar, 2011.

BARROSO, Luís Roberto. Os princípios da razoabilidade e da proporcionalidade no direito constitucional. Boletim de Direito Administrativo, mar., p.156-166, 1997. Disponível em: $\mathrm{https} / /$ www.google.com/url? sa $=\mathrm{t} \& \mathrm{rct}=\mathrm{j} \& \mathrm{q}=\& \mathrm{esrc}=\mathrm{s} \&$ source $=$ web\& $\mathrm{cd}=\& \mathrm{ved}=2 \mathrm{ahUKEwiG}$ yX3-

fxAhVJq5UCHaBWA6UQFjABegQICxAD\&url=https\%3A\%2F\%2Fwww.portaldeperiodicos .idp.edu.br\%2Fcadernovirtual\%2Farticle \%2Fdownload\%2F544\%2F358\&usg=AOvVaw229S _N8H0qjzsipZXSm357. Acesso em: 13 jul. 2021.

BASTOS, Pedro Paulo Zahluth. Pandemia, emissão de moeda e dívida pública no Brasil: uma contribuição para o debate. Nota do Cecon n.15. Campinas: Centro de Estudos de Conjuntura e Política Econômica - IE/UNICAMP, jun., 2020.

BRASIL. Conselho Nacional de Justiça. Judicialização da saúde no Brasil: dados e experiência. ASENSI, Felipe Dutra; PINHEIRO, Roseni (org). Brasília: Conselho Nacional de Justiça, 2015. Disponível em: https://www.cnj.jus.br/wpcontent/uploads/2018/01/4292ed5b6a888bdcac178d51740f4066.pdf. Acesso em: 11 jul. 2021

BRASIL. Conselho Nacional de Justiça. Resolução n. 121, de 5 de outubro de 2010. Dispõe sobre a divulgação de dados processuais eletrônicos na rede mundial de computadores, expedição de certidões judiciais e dá outras providências. DJE/CNJ n ${ }^{0} 187 / 2010$, de 11/10/2010, p. 4 - 6. Disponível em: https://atos.cnj.jus.br/atos/detalhar/atosnormativos?documento=92. Acesso em 24 set. 2020 .

BRASIL. Conselho Nacional de Justiça. Judicialização e saúde: ações para o acesso à saúde pública de qualidade. Brasília: Conselho Nacional de Justiça, 2021. Disponível em: https://www.cnj.jus.br/wp-content/uploads/2021/06/Relatorio_Judicializacao-eSociedade.pdf. Acesso em 12 jul. 2021

BRASIL. Constituição da República Federativa do Brasil. 1988. Brasília, DF: Presidência da República, [2020]. Disponível em: http://www.planalto.gov.br/ccivil_03/Constituicao/ Constituiçao.htm. Acesso em: 20 nov. 2020.

BRASIL, Congresso Nacional. Constituição da República Federativa do Brasil. 1967. Disponível em: http://www.planalto.gov.br/ccivil_03/constituicao/constituicao67.htm. Acesso em 15 mar. 2021.

BRASIL. Lei n. 4.320, de 17 de março de 1964. Estatui Normas Gerais de Direito Financeiro para elaboração e controle dos orçamentos e balanços da União, dos Estados, dos 
Municípios e do Distrito Federal. Brasília, DF: Presidência da República, [1964]. Disponível em: http://www.planalto.gov.br/ccivil_03/leis/14320.htm. Acesso em: 13 mar. 2021.

BRASIL. Lei Complementar n. 101, de 4 de maio de 2000. Estabelece normas de finanças públicas voltadas para a responsabilidade na gestão físcal e dá outras providências. Brasília, DF: Presidência da República, [2000]. Disponível em:

http://www.planalto.gov.br/ccivil_03/leis/lcp/lcp101.htm. Acesso em: 24 set. 2020.

BRASIL. Decreto-Lei $\mathbf{n}^{0}$ 200, de 25 de fevereiro de 1967. Dispõe sobre a organização da Administração Federal, estabelece diretrizes para a Reforma Administrativa e dá outras providências. Brasília, DF: Presidência da República, [1967]. Disponível em: http://www.planalto.gov.br/ccivil_03/decreto-lei/del0200.htm. Acesso em: 24 set. 2020.

BRASIL. Decreto-Lei $\mathbf{n}^{0}$ 201, de 27 de fevereiro de 1967. Dispõe sobre a responsabilidade dos Prefeitos e Vereadores, e dá outras providências. Brasília, DF: Presidência da República, [1967]. Disponível em: http://www.planalto.gov.br/ccivil_03/decreto-lei/del0201.htm. Acesso em: 24 set. 2020.

BRASIL. Decreto-Lei no 2.848, de 7 de Dezembro de 1940. Código Penal. Brasília, DF: Presidência da República. Disponível em: http://www.planalto.gov.br/ccivil_03/decretolei/del2848compilado.htm. Acesso em: 24 set. 2020.

BRASIL. Emenda Constitucional no 86, de 17 de março de 2015. Altera os arts. 165, 166 e 198 da Constituição Federal, para tornar obrigatória a execução da programação orçamentária que especifica. Disponível em:

http://www.planalto.gov.br/ccivil_03/constituicao/emendas/emc/emc86.htm. Acesso em: 24 set. 2020.

BRASIL. Emenda Constitucional n 100, de 26 de junho de 2019. Altera os arts. 165 e 166 da Constituição Federal para tornar obrigatória a execução da programação orçamentária proveniente de emendas de bancada de parlamentares de Estado ou do Distrito Federal. Brasília, DF. Disponível em:

http://www.planalto.gov.br/ccivil_03/constituicao/emendas/emc/emc100.htm. Acesso em: 24 set. 2020.

BRASIL. Lei $\mathbf{n}^{\mathbf{0}}$ 8.429, de 2 de junho de 1992. Dispõe sobre as sanções aplicáveis aos agentes públicos nos casos de enriquecimento ilícito no exercício de mandato, cargo, emprego ou função na administração pública direta, indireta ou fundacional e dá outras providências. Brasília, DF: Presidência da República. Disponível em: http://www.planalto.gov.br/ccivil_03/leis/18429.htm . Acesso em: 24 set. 2020.

BRASIL. Lei n. 1.079 de 10 de abril de 1950. Define os crimes de responsabilidade e regula o respectivo processo de julgamento. Brasília, DF: Presidência da República. Disponível em: http://www.planalto.gov.br/ccivil_03/leis/11079.htm. Acesso em: 24 set. 2020.

BRASIL. Lei n. 8.666 de 21 de junho de 1993. Regulamenta o art. 37, inciso XXI, da Constituição Federal, institui normas para licitações e contratos da Administração Pública e dá outras providências. Disponível em: http://www.planalto.gov.br/ccivil_03/leis/18666cons.htm. Acesso em: 20 jul 2021. 
BRASIL. Lei n. 14.133 de $\mathbf{1}^{\circ}$ de abril de 2021. Lei de Licitações e Contratos Administrativos. Disponível em: http://www.planalto.gov.br/ccivil_03/_Ato20192022/2021/Lei/L14133.htm\#art193. Acesso em 20 jul 2021.

BRASIL. Lei n. 13.105, de 16 de março de 2015. Código de Processo Civil. Brasília, DF: Presidência da República. Disponível em: http://www.planalto.gov.br/ccivil_03/_ato20152018/2015/lei/113105.htm. Acesso em: 24 set. 2020.

BRASIL. Superior Tribunal de Justiça. (2. Turma). Recurso Especial 1.389.952/MT. Constitucional e Administrativo. Cadeia Pública. Superlotação. Condições Precárias. Ação Civil Pública para obrigar o Estado a adotar providências administrativas e apresentar previsão orçamentária para reformar ou construir nova unidade prisional. Alegação de ofensa ao Princípio da Separação de Poderes e de necessidade de prévia dotação orçamentária (Arts. $4^{\circ}, 6^{\circ}$ e 60 da Lei 4.320/64). Controle Judicial de Políticas Públicas em casos excepcionais. Possibilidade. Caso concreto cuja moldura fática evidencia ofensa à garantia constitucional do respeito à integridade física e moral dos presos e aos princípios da dignidade da pessoa humana e do mínimo existencial, contra o qual não se pode opor a Reserva do Possível. [...] . Recurso Especial não provido. Relator: Min. Herman Benjamin, 3 de junho de 2014. Disponível em:

https://scon.stj.jus.br/SCON/jurisprudencia/toc.jsp?i=1\&b=ACOR\&livre=((\%27RESP\%27.cl as.+e+@num=\%271389952\%27)+ou+(\%27REsp\%27+adj+\%271389952\%27.suce. $)) \&$ thesau rus=JURIDICO\&fr=veja . Acesso em: 17 ago. 2020.

BRASIL. Superior Tribunal de Justiça (2. Turma). Agravo Regimental no Agravo em Recurso Especial 790.767/MG. Administrativo e constitucional. Acesso à creche aos menores de zero a seis anos. Direito subjetivo. Reserva do possível. Teorização e cabimento. Impossibilidade de arguição como tese abstrata de defesa. Escassez de recursos como o resultado de uma decisão política. Prioridade dos direitos fundamentais. Conteúdo do mínimo existencial. Essencialidade do direito à educação. Precedentes do STF e STJ [...].Agravo regimental improvido. Relator: Min. Humberto Martins, 3 de dezembro de 2015. Disponível em:

https://processo.stj.jus.br/processo/revista/documento/mediado/? componente=ITA\&sequencia $\mathrm{l}=1473142 \&$ num_registro $=201502487840 \&$ data $=20151214 \&$ peticao_numero $=20150048737$ 4\&formato=PDF. Acesso em: 15 ago. 2020.

BRASIL. Superior Tribunal de Justiça (2. Turma). Agravo Regimental no Recurso Especial 1.107.511/RS. Administrativo. Controle judicial de políticas públicas. Possibilidade em casos excepcionais - direito à saúde. Fornecimento de medicamentos. Manifesta necessidade. Obrigação solidária de todos os entes do poder público. Não oponibilidade da reserva do possível ao mínimo existencial. Não há ofensa à súmula 126/STJ. Relator: Min. Herman Benjamin, 21 de novembro de 2013, Disponível em:

https://scon.stj.jus.br/CON/GetInteiroTeorDoAcordao?num_registro=200802653389\&dt_pub licacao=06/12/2013. Acesso em: 15 ago. 2020.

BRASIL. Superior Tribunal de Justiça. Mandado de Segurança 18.286/DF. Administrativo e processo civil. Mandado de segurança. Anistia política. Militar. Marinha. Indenização. Pagamento. Retroativos. Litispendência afastada pelo stf. Demais preliminares rejeitadas. 
Ausência de firma do termo de acordo da lei n. 11.354, de 2006. Mera faculdade. Existência de previsão orçamentária. Matéria pacificada na primeira seção do STJ. Questão de ordem. Ressalvada. Relator: Min. Humberto Martins, 27 de maio de 2015.

Disponível em:

https://scon.stj.jus.br/SCON/GetInteiroTeorDoAcordao?num_registro=201200475225\&dt_pu blicacao=02/06/2015. Acesso em: 13 jul. 2020.

BRASIL. Superior Tribunal de Justiça. Mandado de Segurança 21.456/DF. Administrativo. Mandado de segurança. Anistiado político. Efeitos retroativos da reparação econômica. Decadência não configurada. Cabimento do writ. Previsão dos recursos mediante rubrica própria nas leis orçamentárias. Possibilidade de execução contra a fazenda pública, por meio de precatórios, caso não seja possível o pagamento em uma única parcela, em dinheiro. Omissão configurada. Direito líquido e certo ao integral cumprimento da portaria, enquanto não cassada ou revogada. Segurança concedida. Relator: Min. Napoleão Nunes Maia Filho, 25 de fevereiro de 2016. Disponível em:

https://scon.stj.jus.br/SCON/GetInteiroTeorDoAcordao?num_registro=201403333960\&dt_pu blicacao=03/03/2016. Acesso em: 11 jun. 2020.

BRASIL. Superior Tribunal de Justiça. Mandado de Segurança 21.479/DF. Administrativo e processual civil. Mandado de segurança. Anistia política. Militar. Pagamento de reparação econômica retroativa. Cabimento. Ato omissivo continuado. Decadência. Não configuração. Não incidência das súmulas 269 e 271/SET. Descumprimento do prazo previsto na lei 10.559/2002. Previsão dos recursos, mediante rubrica própria, nas leis orçamentárias. Omissão configurada. Precedentes do STJ e do STF, em regime de repercussão geral (re 553.710/df - tema 394). Direito líquido e certo ao integral cumprimento da portaria anistiadora, enquanto não cassada ou revogada. Precedentes. Segurança concedida. Relatora: Min. Assusete Magalhães, 14 de dezembro de 2016. Disponível em: https://scon.stj.jus.br/SCON/GetInteiroTeorDoAcordao?num_registro=201403406910\&dt_pu blicacao=19/12/2016. Acesso em: 14 jun. 2020.

BRASIL. Superior Tribunal de Justiça. (2. Turma). Recurso Especial 1.185.474/SC. Administrativo E Constitucional - Acesso à creche aos menores de zero a seis anos - Direito Subjetivo - Reserva Do Possível - Teorização e Cabimento - Impossibilidade de arguição como tese abstrata de defesa - Escassez de recursos como o resultado de uma decisão política - Prioridade dos Direitos Fundamentais - Conteúdo do mínimo existencial - Essencialidade do direito à educação - Precedentes do STF e STJ. [...] . Recurso Especial improvido. Relator: Min. Humberto Martins, 20 de abril de 2010. Disponível em:

https://scon.stj.jus.br/SCON/GetInteiroTeorDoAcordao?num_registro=201000486284\&dt_pu blicacao $=29 / 04 / 2010$. Acesso em: 22 abr. 2020.

\section{BRASIL. Supremo Tribunal Federal. (2. Turma). Agravo Regimental no Recurso}

Extraordinário com Agravo 1.189.014/SP. Recurso extraordinário com agravo - Ação civil pública para reforma em prédio do Departamento Regional de Saúde - Obrigação jurídicoconstitucional que impõe ao poder público o dever de observância do direito constitucional de acessibilidade às pessoas com deficiência (cf, art. $\left.227, \S 2^{\circ}\right)$ - implementação de políticas públicas - Violação aos princípios da separação dos poderes e da reservado possível Inocorrência - Decisão que se ajusta à jurisprudência prevalecente no Supremo Tribunal Federal - Consequente inviabilidade do recurso que a impugna - sucumbência recursal (CPC, art. 85, § 11) - Não decretação, no caso, ante a ausência de condenação em verba 
honorária na origem - Agravo interno improvido. Relator: Min. Celso de Mello, 27 de setembro de 2019. Disponível em:

http://redir.stf.jus.br/paginadorpub/paginador.jsp?docTP=TP\&docID=751098039. Acesso em: 24 mar. 2020.

BRASIL. Supremo Tribunal Federal (STF). Regimento interno [recurso eletrônico]. Supremo Tribunal Federal. - Brasília: STF, Secretaria de Altos Estudos, Pesquisas e Gestão da Informação, 2020. Disponível em:

http://www.stf.jus.br/arquivo/cms/legislacaoRegimentoInterno/anexo/RISTF.pdf . Acesso em: 24 set. 2020.

BRASIL. Supremo Tribunal Federal (Tribunal Pleno). Intervenção Federal 470-5/SP. Intervenção Federal. 2. Precatórios judiciais. 3. Não configuração de atuação dolosa e deliberada do Estado de São Paulo com finalidade de não pagamento. 4. Estado sujeito a quadro de múltiplas obrigações de idêntica hierarquia. Necessidade de garantir eficácia a outras normas constitucionais, como, por exemplo, a continuidade de prestação de serviços públicos. 5. A intervenção, como medida extrema, deve atender à máxima da proporcionalidade. 6 . Adoção da chamada relação de precedência condicionada entre princípios constitucionais concorrentes. 7. Pedido de intervenção indeferido. Relator: Min. Marco Aurélio. Relator para Acórdão: Min. Gilmar Mendes, 26 de fevereiro de 2003. Disponível em: http://redir.stf.jus.br/paginadorpub/paginador.jsp?docTP=AC\&docID=81042. Acesso em: 29 set. 2020.

BRASIL. Supremo Tribunal Federal (Tribunal Pleno). Recurso Extraordinário 592.581/RS. Repercussão Geral. Recurso do MPE contra acórdão do TJRS. Reforma de sentença que determinava a execução de obras na casa do albergado de Uruguaiana. Alegada ofensa ao princípio da separação dos poderes e desbordamento dos limites da reserva do possível. Inocorrência. Decisão que considerou direitos constitucionais de presos meras normas programáticas. Inadmissibilidade. Preceitos que têm eficácia plena e aplicabilidade imediata. Intervenção judicial que se mostra necessária e adequada para preservar o valor fundamental da pessoa humana. Observância, ademais, do postulado da inafastabilidade da jurisdição. Recurso conhecido e provido para manter a sentença cassada pelo Tribunal. Relator: Min. Ricardo Lewandowski, 13 de agosto de 2015. Disponível em:

https://redir.stf.jus.br/paginadorpub/paginador.jsp?docTP=TP\&docID=10166964. Acesso em 30 set. 2020 .

BRASIL. Supremo Tribunal Federal (Tribunal Pleno). Recurso Extraordinário 553.710/DF. Direito Constitucional e Administrativo. Mandado de segurança. Anistiado político. Pagamento retroativo de prestação mensal concedida. Norma que torna vinculante requisição ou decisão administrativa de órgão competente que determina o pagamento pela União. Dívida da Fazenda Pública que não foi reconhecida por decisão do Poder Judiciário. Afastamento do regime do art. 100 da Constituição Federal. Obrigação de fazer que está sendo descumprida. Repercussão geral reconhecida. Recurso extraordinário a que se nega provimento. Tese fixada. [...]. Relator: Min. Dias Toffoli, 23 de novembro de 2016. Disponível em: http://redir.stf.jus.br/paginadorpub/paginador.jsp?docTP=TP\&docID=13499625. Acesso em: 9 maio 2019.

BRASIL. Supremo Tribunal Federal (Tribunal Pleno). Recurso Extraordinário 580.252/MS. Recurso extraordinário representativo da controvérsia. Repercussão Geral. Constitucional. 
Responsabilidade civil do Estado. Art. $37, \S 6^{\circ} .2$. Violação a direitos fundamentais causadora de danos pessoais a detentos em estabelecimentos carcerários. Indenização. Cabimento. $\mathrm{O}$ dever de ressarcir danos, inclusive morais, efetivamente causados por ato de agentes estatais ou pela inadequação dos serviços públicos decorre diretamente do art. $37, \S 6^{\circ}$, da Constituição, disposição normativa autoaplicável. Ocorrendo o dano e estabelecido o nexo causal com a atuação da Administração ou de seus agentes, nasce a responsabilidade civil do Estado. 3. "Princípio da reserva do possível". Inaplicabilidade. O Estado é responsável pela guarda e segurança das pessoas submetidas a encarceramento, enquanto permanecerem detidas. É seu dever mantê-las em condições carcerárias com mínimos padrões de humanidade estabelecidos em lei, bem como, se for o caso, ressarcir danos que daí decorrerem. [...]. Relator: Min. Teori Zavascki. Relator para Acórdão: Min. Gilmar Mendes, 16 de fevereiro de 2017. Disponível em:

http://redir.stf.jus.br/paginadorpub/paginador.jsp?docTP=TP\&docID=13578623. Acesso em: 22 maio 2020.

BRASIL. Supremo Tribunal Federal (Tribunal Pleno). Recurso Extraordinário 587.970/SP. Assistência Social - Estrangeiros Residentes no País - Artigo 203, Inciso V, da Constituição Federal - Alcance. Relator: Min. Marco Aurélio, 20 de abril de 2017. Disponível em: http://redir.stf.jus.br/paginadorpub/paginador.jsp?docTP=TP\&docID=13649377. Acesso em: 1 maio 2020.

BRASIL. Supremo Tribunal Federal (Tribunal Pleno). Recurso Extraordinário 567.985/MT. Benefício assistencial de prestação continuada ao idoso e ao deficiente. Art. 203, V, da Constituição.A Lei de Organização da Assistência Social (LOAS), ao regulamentar o art. 203, $\mathrm{V}$, da Constituição da República, estabeleceu os critérios para que o benefício mensal de um salário mínimo seja concedido aos portadores de deficiência e aos idosos que comprovem não possuir meios de prover a própria manutenção ou de tê-la provida por sua família. 2 . Art. $20, \S$ $3^{\circ}$, da Lei 8.742/1993 e a declaração de constitucionalidade da norma pelo Supremo Tribunal Federal na ADI. 232. [...].O requisito financeiro estabelecido pela lei teve sua constitucionalidade contestada, ao fundamento de que permitiria que situações de patente miserabilidade social fossem consideradas fora do alcance do benefício assistencial previsto constitucionalmente[...] O Supremo Tribunal Federal, em decisões monocráticas, passou a rever anteriores posicionamentos acerca da intransponibilidade dos critérios objetivos. Verificou-se a ocorrência do processo de inconstitucionalização decorrente de notórias mudanças fáticas (políticas, econômicas e sociais) e jurídicas (sucessivas modificações legislativas dos patamares econômicos utilizados como critérios de concessão de outros benefícios assistenciais por parte do Estado brasileiro). 4. Declaração de inconstitucionalidade parcial, sem pronúncia de nulidade, do art. $20, \S 3^{\circ}$, da Lei 8.742/1993.5. Recurso extraordinário a que se nega provimento. Relator: Min. Marco Aurélio. Redator: Min. Gilmar Mendes, 18 de abril de 2013. Disponível em: http://redir.stf.jus.br/paginadorpub/paginador.jsp?docTP=TP\&docID=4614447. Acesso em 20 mar. 2020.

BRASIL. Supremo Tribunal Federal (Tribunal Pleno). Recurso Extraordinário 641.320/RS. Constitucional. Direito Penal. Execução penal. Repercussão geral. Recurso extraordinário representativo da controvérsia. 2. Cumprimento de pena em regime fechado, na hipótese de inexistir vaga em estabelecimento adequado a seu regime. Violação aos princípios da individualização da pena (art. 5\%, XLVI) e da legalidade (art. 5, XXXIX). [...] Apelo ao legislador para que avalie a possibilidade de reformular a execução penal e a legislação 
correlata, para: (i) reformular a legislação de execução penal, adequando-a à realidade, sem abrir mão de parâmetros rígidos de respeito aos direitos fundamentais; (ii) compatibilizar os estabelecimentos penais à atual realidade; (iii) impedir o contingenciamento do FUNPEN[...] 6. Decisão de caráter aditivo. [...] 7. Estabelecimento de interpretação conforme a Constituição para (a) excluir qualquer interpretação que permita o contingenciamento do Fundo Penitenciário Nacional (FUNPEN), criado pela Lei Complementar 79/94; b) estabelecer que a utilização de recursos do Fundo Penitenciário Nacional (FUNPEN) para financiar centrais de monitoração eletrônica e penas alternativas é compatível com a interpretação do art. $3^{\circ}$ da Lei Complementar 79/94 [...]. Relator: Min. Gilmar Mendes, 11 de maio de 2016. Disponível em:

http://redir.stf.jus.br/paginadorpub/paginador.jsp?docTP=TP\&docID=11436372. Acesso em: 20 mar. 2020.

BRASIL. Supremo Tribunal Federal. Resolução n. 427 de 20 de abril de 2010. Regulamenta o processo eletrônico no âmbito do Supremo Tribunal Federal. Brasília: DJE/STF, n. 72, 26 abr., 2010. Disponível em: http://www.stf.jus.br/ARQUIVO/NORMA/RESOLUCAO4272010.PDF. Acesso em: 3 abr. 2021.

BRASIL. Tribunal de Contas da União. Relatório de auditoria (RA) 018047/2018-1. Relatório de Auditoria Integrada (Operacional e Conformidade). Fiscalização de Orientação Centralizada. Avaliação da Regularidade dos Repasses Obrigatórios de Recursos do Fundo Penitenciário Nacional (FUNPEN) às Unidades Federativas. Insuficiência dos Repasses Obrigatórios do FUNPEN diante da realidade do sistema. Atrasos nos cronogramas das obras. Baixo ritmo de criação de vagas prisionais. Deficiências no planejamento orçamentário do Fundo. Atrasos e omissões no envio de documentos. Determinações. Recomendações. Ciência. Relatora: Min Ana Arraes, 03 de julho de 2019. Disponível em: https://pesquisa.apps.tcu.gov.br/\#/documento/acordaocompleto/1804720181.PROC/\%2520/DTRELEVANCIA \%2520desc\%252C\%2520NUMACO RDAOINT\%2520desc/0/\%2520. Acesso em 20 dez. 2020.

BULOS, Uadi Lammêgo. Finanças públicas e orçamento. Rio de Janeiro: Revista de Direito Administrativo, v. 211, p. 281-299, jan./mar. 1998.

CAMARGO, Margarida Maria Lacombre. O peso da argumentação empírica na jurisdição constitucional. In: ALEXY. R., TREVISONNO, A. T. G.; SALIBA, A. T.; LOPES, M. S. (orgs.). Princípios formais e outros aspectos da teoria discursiva do direito. $2^{\mathrm{a}}$ ed. Rio de Janeiro: Forense, p. 71-76, 2018.

CAMBI, Eduardo. Neoconstitucionalismo e Neoprocessualismo. São Paulo: Almedina Brasil, 2018.

CANOTILHO, J.J. Gomes. Direito Constitucional e Teoria da Constituição. $7^{\mathrm{a}}$ ed., $21^{\mathrm{a}}$ reimp., Coimbra: Edições Almedina. 2013.

CARNEIRO, Wálber Araújo. Escassez, eficácia e direitos sociais. In: Revista do Programa de Pós-Graduação em Direito da UFBA. Salvador: Faculdade de Direito: EDUFBA, p. 371 388, jan-dez, 2004.

CLARK, Giovani, CORREA, Leonardo Alves, NASCIMENTO, Samuel Pontes. Ideologia 
constitucional e pluralismo produtivo. Revista da Faculdade de Direito UFMG: número Especial em Memória do Prof. Washington Peluso. Belo Horizonte, p. 265-300, 2013.

COACCI, Thiago. A pesquisa com acórdãos nas ciências sociais: algumas reflexões metodológicas. Dossiê - métodos e fontes de pesquisa em ciências sociais. v. 18, n.2, p.86$109,2013$.

DINIZ, Josedilton Alves e LIMA, Severino Cesário. Contabilidade Pública. Análise financeira governamental. São Paulo: Atlas, 2016.

FANDIÑO, Pedro; KERSTENETZKY, Célia Lessa. O paradoxo constitucional brasileiro: direitos fundamentais sociais sob tributação regressiva. Revista de Economia Política, v. 39, n. 2, São Paulo, p. 306-327, jun. 2019. Disponível em:

http://www.scielo.br/scielo.php?script=sciarttext\&pid=S0101-

$31572019000200006 \& \operatorname{lng}=$ en\&nrm=iso. Acesso em: 25 out. 2020.

FERNANDES, Andressa Guimarães Torquato; SILVEIRA, Alexandre Coutinho. Capítulo 1 Receitas Públicas. In: OLIVEIRA, Regis Fernandes; HORVATH, Estevão; CONTI, José Maurício; SCAFF, Fernando Facury. Lições de Direito Financeiro. São Paulo: Editora Revista dos Tribunais, p. 19-35, 2016.

FERRARI, Regina Maria Macedo Nery. Normas constitucionais programáticas.

Normatividade, operatividade e efetividade. São Paulo: Ed. Revista dos Tribunais Ltda., 2001.

FERREIRA, Francisco Gilney Bezerra de Carvalho. Orçamento público e separação de poderes no estado constitucional democrático brasileiro. Rio de Janeiro: Lumen Juris, 2018.

GAIER, Reinhard. Pretensões positivas contra o Estado e a Reserva do Possível na jurisprudência do Tribunal Constitucional Federal. In: SEMINÁRIO INTERNACIONAL BRASIL - ALEMANHA: THOMPSON FLORES (PORTUGUÊS - ALEMÃO), 2., 2011, Florianópolis. Série Cadernos do CEJ, n. 27. Brasília: CJF, p.13-21, 2011.

GALDINO, Flávio. O custo dos direitos. In: BARCELLOS, Ana Paula de; et al. TORRES, Ricardo Lobo (org.). A legitimação dos direitos humanos. Rio de Janeiro: Renovar, p. 139222, 2002. Disponível em:

https://edisciplinas.usp.br/pluginfile.php/765022/mod_resource/content/2/Aula\%2012.pdf. Acesso em:13 jul 2021.

GLOBEKNER, Osmir Antonio. Racionalidade econômica, escolhas trágicas e o custo dos direitos no acesso à saúde. Dikè - XVI. Revista Jurídica do Curso de Direito da UESC, p. 120-149, 2017.

GOIS FILHO, Eduardo Antônio Varela de. Reserva de contingência pública. Jus Navigandi, Teresina, n. 14, n. 2142, 13 maio 2009. Disponível em:

http://jus.uol.com.br/revista/texto/12848. Acesso em: 16 ago. 2019. 
GOMES, Mário Soares Caymmi. Apontamentos para uma análise retórica da reserva do possível como limitador da eficácia dos direitos fundamentais. Entre Aspas: Revista da Unicorp/Tribunal de Justiça do Estado da Bahia. v. 3. Salvador - Universidade Corporativa do TJBA, p. 80-98, mar. 2013.

GRINOVER, Ada Pellegrini. O controle de políticas públicas pelo Poder Judiciário. Revista do Curso de Direito da Faculdade de Humanidades e Direito. v. 7, n. 7. p. 9-37, 2010.

HESSE, Konrad. Elementos de Direito Constitucional da República Federal da Alemanha (tradução da $20^{\mathrm{a}}$ edição alemã). HECK, Luís Afonso (trad.). Porto Alegre: Sergio Antonio Fabris Editor, 1998.

HOLMES, Stephen; SUNSTEIN, Cass R. O custo dos direitos: porque a liberdade depende os impostos. Trad. Marcelo de Brandão Cipolla. São Paulo: Editora WMF Martins Fontes. [livro eletrônico. Kindle], 2019.

KLATT, Mathias. Direitos a prestações positivas: quem deve decidir? Controle judicial ponderado. In: ALEXY, Robert; BAEZ, Narciso Leandro Xavier; SILVA, Rogério Luiz Nery da (org.). Dignidade humana, direitos sociais e não-positivismo inclusivo. Florianópolis: Qualis, p. 215-266, 2015.

KRELL, Andreas Joachim. Direitos sociais e Controle Judicial no Brasil e na Alemanha: os (des)caminhos de um Direito Constitucional "Comparado". 1. ed. Porto Alegre: SAFE, 2002.

LEITE, Harison Ferreira. Autoridade da lei orçamentária. Porto Alegre: Livraria do Advogado Editora Ltda. [livro digital], 2011.

LIMA, Edilberto Carlos Pontes. Curso de finanças públicas. Uma abordagem contemporânea. São Paulo: Atlas S.A., 2015.

LOCHAGIN, Gabriel Loreto. A execução do orçamento público: flexibilidade e orçamento impositivo. [livro eletrônico].São Paulo: Blucher, 2016

MARINO, Leonardo Romero. Moldando a "reserva do possível" no tempo: a sustentabilidade fiscal como direito difuso fundamental. Revista Brasileira de Políticas Públicas. v. 5, n.1, jan./jun., 2015.

MARINONI, Luis Guilherme; ARENHART, Sérgio Cruz. Prova. São Paulo: RT, 2009.

MARTINS, Flávio. Direitos sociais em tempos de crise econômica. São Paulo: Saraiva Educação. [livro eletrônico], 2020.

MENDONÇA, Eduardo Bastos Furtado de. A constitucionalização das finanças públicas no Brasil. Devido processo orçamentário e democracia. Rio de Janeiro: Renovar, 2010.

MENDONÇA, Mário Jorge. Uma análise crítica da teoria quantitativa da moeda. Economia \& Tecnologia - ano 07, vol. 25, abr./jun., 2011. Disponível em: 
http://www.economiaetecnologia.ufpr.br/revista/25\%20Capa/Mario\%20Jorge\%20Mendonca. pdf . Acesso em: 16 jan 2021.

MOREIRA, Alinie da Matta. As restrições em torno da reserva do possível: uma análise crítica. Belo Horizonte: Fórum, 2011.

MOURA, Emerson Affonso da Costa; RIBEIRO, Jamir Calili. Direitos fundamentais sociais, orçamento público e reserva do possível: o dever de progressividade nos gastos públicos. São Paulo: Revista de Direito Brasileira. v. 16, n. 7, jan./abr., p. 225-241, 2017.

MOTA, Mauricio Jorge Pereira da; PEREIRA, Daniel Queiroz. Argumentação jurídica, ponderação e representatividade argumentativa na obra de Robert Alexy. Revista Quaestio Iuris, v.5, n. 1, p.21-50, 2012.

NASCIMENTO, Assis José Couto do. O estado da luxúria: a parábola do BMW e a real dimensão do debate sobre a reserva do possível: escassez de recursos ou ordenação de prioridades?. Revista

Brasileira de Políticas Públicas, v. 9, n.1, p. 483-500, abr. 2019.

NEVES, Vítor. Custos sociais: onde para o mercado?. Revista Crítica de Ciências Sociais [online], n. 95, p. 55-68, 2011. Disponível em: http://journals.openedition.org/rccs/4368. Acesso em: 23 out. 2019.

NOVAIS, Jorge. Direitos fundamentais: trunfos contra a maioria.Coimbra Editora, 2006.

NUNES JÚNIOR, Vidal Serrano. A cidadania social na Constituição de 1988 - Estratégias de positivação e exigibilidade judicial dos direitos sociais. São Paulo: Ed. Verbatim, p.176$177,2009$.

OLIVEIRA, André Luis Morais. O princípio da livre convicção motivada no processo do trabalho: a argumentação jurídica e o domínio da racionalidade do juízo de convencimento. Dissertação (Mestrado) - Universidade Federal de São Paulo, Programa de Pós-Graduação em Direito, da Faculdade de Direito da Universidade de São Paulo, 2016.

OLSEN, Ana Carolina Lopes. A eficácia dos direitos fundamentais sociais frente à reserva do possível. Dissertação (Mestrado) - Universidade Federal do Paraná, Faculdade de Direito. Programa de Pós-Graduação em Direito do Setor de Ciências Jurídicas, 2006.

PERLINGEIRO, Ricardo. É a reserva do possível um limite à intervenção jurisdicional nas políticas públicas sociais? Revista de Direito Administrativo Contemporâneo, São Paulo, v. 2, p. 163-185, set./out. 2013.

PINHEIRO, Victor Sales; NEIVA, Horácio Lopes Mousinho. Razão prática, direito e bem comum na teoria da lei natural de John Finnis. Queastio Iuris, vol. 12, nº. 02, Rio de Janeiro, pp. 240-265. 2019. DOI: 10.12957/rqi.2019.39074. Disponível em: https://www.epublicacoes.uerj.br/index.php/quaestioiuris/article/view/39074/32547. Acesso em: 13 jul 2021.

PINTO, Elida Graziane. Eficácia dos direitos fundamentais sociais por meio do controle judicial da legalidade orçamentária e da sua adequada execução. Revista Fórum de Direito Econômico e Financeiro - RFDFE, Belo Horizonte, ano 3, n. 5, p. 71-100, mar./ago. 2014. 
PINTO, Élida Graziane. Indicação judicial de fonte de custeio desvendará penumbras.

ConJur - Revista Consultor Jurídico. 23 abr. 2019. Disponível em:

https://www.conjur.com.br/2019-abr-23. Acesso em: 24 jul. 2019.

PINTO, Élida Graziane. Controle judicial dos orçamentos públicos em prol dos direitos fundamentais. Consultor Jurídico. ago. 2017. Disponível em: https://www.conjur.com.br/2016-ago-17/elida-pinto-controle-orcamentario-prol-direitosfundamentais?imprimir=1. Acesso em: 10 set. 2019.

PORTO, Sérgio Gilberto. Sobre a common law, civil law e o precedente judicial. In: MARINONI, Luiz Guilherme (org.). Estudos de direito processual civil - Homenagem ao Professor Egas Dirceu Moniz de Aragão, São Paulo: Editora Revista dos Tribunais, 2006. Disponível em: http://www.abdpc.org.br/abdpc/artigos/Sergio\%20porto-formatado.pdf. Acesso em: 31 dez. 2020.

RESENDE, André Lara. Consenso e Contrassenso: déficit, dívida e previdência. Texto para discussão n ${ }^{0} 47$. IEPE/CdG, fev, 2019. Disponível em: http://iepecdg.com.br/wpcontent/uploads/2019/02/Consensoecontrasenso.docx..pdf. Acesso em: 25 out. 2020.

SARLET, Ingo Wolfgang. Teoria geral dos direitos fundamentais. In: SARLET, Ingo Wolfgang; MARINONI, Luiz Guilherme; MITIDIERO, Daniel. Curso de direito constitucional. $6^{\text {a }}$ ed. rev. ampl., São Paulo: Saraiva, p. 301-398, 2017.

SARLET, Ingo Wolfgang. Direitos fundamentais em espécie. In: SARLET, Ingo Wolfgang; MARINONI, Luiz Guilherme; MITIDIERO, Daniel. Curso de direito constitucional. $6^{\mathrm{a}}$ ed. rev. ampl., São Paulo: Saraiva, p. 402-764, 2017a.

SARLET, Ingo Wolfgang. Direitos sociais como direitos subjetivos: a nova decisão da corte alemã. Revista Consultor Jurídico, jun., 2017b. Disponível em: https://www.conjur.com.br/2017-jun-02/direito-fundamentais-direitos-sociais-subjetivosanova-decisao-corte-alema. Acesso em: 12 jul. 2021.

SARLET, Ingo Wolfgang. O Tribunal Constitucional Federal da Alemanha e o direito ao ensino superior. Revista Consultor Jurídico, jan., 2018. Disponível em: https://www.conjur.com.br/2018-jan-05/direitos-fundamentais-tribunal-constitucionalalemanha-direito-ensino-superior . Acesso em: 12 jul 2021.

SARLET, Ingo Wolfgang; FIGUEIREDO, Mariana Filchtiner. Reserva do Possível, mínimo existencial e direito à saúde: algumas aproximações. In: SARLET, Ingo Wolfgang; TIMM, Luciano Benetti (org). Direitos Fundamentais, orçamento e "reserva do possível". $2^{\mathrm{a}}$ ed. rev. ampl. $2^{\mathrm{a}}$ tiragem. Porto Alegre: Livraria do Advogado, p. 13-50, 2013.

SARMENTO, Daniel. O mínimo existencial. Revista de Direito da Cidade, v. 8, n.4, p. 1644-1689, 2016.

SCAFF, Fernando Facury. O orçamento republicano e a busca da liberdade igual. In: SCAFF, Fernando Facury. Orçamento republicano e liberdade igual - Ensaio sobre Direito Financeiro, República e Direito Fundamentais no Brasil. Belo Horizonte: Fórum, 2018. 
SCAFF, Fernando Facury. Você nem sabe, mas vive entre a reserva do possível e as escolhas trágicas. Conjur - Revista Consultor Jurídico. 23 jan. 2018. Disponível em: https://www.conjur.com.br/2018-jan-23/contas-vista-vivemos-entre-reserva-possivelescolhas-tragicas. Acesso em: 9 jun. 2019.

SCHWABE, Jürgen. Cinquenta anos de jurisprudência do Tribunal Constitucional Federal Alemão. v. 2, Tradução MARTINS, Leonardo et al. Montevideo: Fundação Konrad Adenauer, 2005. Disponível em:

https://www.kas.de/c/document_library/get_file?uuid=c0b3d47d-beba-eb55-0b11df6c530ddf52\&groupId=252038. Acesso em: 12 jul. 2021.

SGARBOSSA. Luís Fernando. Crítica à teoria dos custos dos direitos: Volume 1. Reserva do Possível. Porto Alegre: Sérgio Antônio Fabris Editora, 2010.

SILVA, Carlos Augusto Lima Vaz da. O Princípio da Reserva do Possível na Jurisprudência do Supremo Tribunal Federal. Dissertação (Mestrado) - Universidade Federal de Juiz de Fora, Faculdade de Direito. Programa de Pós-Graduação em Direito e Inovação, 2019.

SILVA, Virgílio Afonso. O conteúdo essencial dos direitos fundamentais e a eficácia das normas constitucionais. Revista de Direito do Estado. p 23-51, 2006. Disponível em: https://constituicao.direito.usp.br/wp-content/uploads/2006-RDE4-Conteudo_essencial.pdf. Acesso em 12 fev. 2021.

SILVA, Virgílio Afonso. O proporcional e o razoável. Revista dos Tribunais, n 798. p 23-50, 2002. Disponível em: https://constituicao.direito.usp.br/wp-content/uploads/2006-RDE4Conteudo_essencial.pdf. Acesso em 12 fev. 2021.

SILVEIRA, Francisco Secaf Alves. A concretização do direito financeiro: os efeitos do contingenciamento na execução orçamentária. 2014. Dissertação (Mestrado) - Faculdade de Direito, Universidade de São Paulo, São Paulo, 2014.

SILVEIRA, Francisco Secaf Alves. Problemas e diagnósticos na execução do planejamento orçamentário. Revista Fórum de Direito Financeiro e Econômico- RFDFE. Belo Horizonte, ano 4, n. 6, p. 59-78, set/fev, 2015.

STEINMET, Wilson Antônio. O dever de aplicação imediata de direitos e garantias fundamentais na jurisprudência do Supremo Tribunal Federal e nas interpretações da literatura especializada. In: Encontro Nacional do CONPEDI, 19., Fortaleza, Anais [...], p. 4488-4499, 2010. Disponível em:

http://www.publicadireito.com.br/conpedi/manaus/arquivos/anais/fortaleza/3105.pdf. Acesso em: 10 set. 2020.

TOLEDO, Cláudia et al. Direitos fundamentais sociais e mínimo existencial na realidade latino-americana - Brasil, Argentina, Colômbia e México. Direitos Fundamentais \& Justiça. Belo Horizonte, ano 13, n. 41, p. 213-239, jul./dez. 2019.

TOLEDO, Cláudia. O pensamento de Robert Alexy como sistema - argumentação jurídica, 
direitos fundamentais, conceito e validade do Direito. In: TOLEDO, Cláudia (org.). $\mathbf{O}$ pensamento de Robert Alexy como sistema. Rio de Janeiro: Forense Universitária, p. 29-47, 2017.

TOLEDO, Cláudia. Pretensão de Correção no Pensamento de Robert Alexy - Da necessária formulação da pretensão de correção pelo Direito e da necessária conexão entre Direito e Moral. [s.1.: s.n..], 2021.

TORRES, Ricardo Lobo. O mínimo existencial e os direitos fundamentais. Revista de Direito Administrativo. Rio de Janeiro, n.177, p. 29-49, jul./set.1989.

TORRES, Ricardo Lobo. O mínimo existencial os direitos sociais e os desafios de natureza orçamentária. In: SARLET, I. W ; TIMM, L . B. (org.). Direitos fundamentais, orçamento e "reserva do possível". Porto Alegre: Livraria do Advogado, p. 63-78, 2013. Disponível em: http://bibliotecadigital.fgv.br/ojs/index.php/rda/article/view/46113/44271. Acesso em: 22 abr. 2020.

TORRES, Ricardo Lobo. Tratado de direito financeiro e tributário. Volume V: o orçamento na Constituição. $2^{\mathrm{a}}$ ed. rev. e atual. Rio de Janeiro: Renovar, 2000.

TRIVISONNO, Alexandre Travessoni Gomes. A distinção entre discricionariedade legislativa e judicial: uma proposta a partir das teorias de Kelsen e Alexy. In: TOLEDO, Cláudia (org.). O pensamento de Robert Alexy como sistema. Rio de Janeiro: Forense Universitária, p. 99$128,2017$.

TRIVISONNO, Alexandre Travessoni Gomes. O problema do conhecimento pra'tico na teoria discursiva do Direito de Alexy. In: TRIVISONNO, Alexandre Travessoni Gomes; SALIBA, Aziz Tuffi; LOPES, Mônica Sette (org.). Princípios formais e outros aspectos da teoria discursiva do direito/ Robert Alexy. $2^{\mathrm{a}}$ ed. Rio de Janeiro: Forense, p.27-47, 2018.

VENÂNCIO, Denilson Marcondes. O desvio de poder orçamentário. Rio de Janeiro: Lumen Juris, 2016.

WANG, Daniel Wei Liang. Escassez de recursos, custos dos direitos e reserva do possível na jurisprudência do STF. In: SARLET, Ingo; TIMM, Luciano Benetti (org.). Direitos Fundamentais, Orçamento e Reserva do Possível. $2^{\mathrm{a}}$ ed. Porto Alegre: Livraria do Advogado, p. 368-369, 2013.

WATANABE, Kazuo. Da cognição no processo civil. São Paulo: Revista dos Tribunais, 1987.

World Inequality Lab. World Inequality Report 2018. Disponível em: https://wir2018.wid.world/files/download/wir2018-full-report-english.pdf. Acesso em: 25 out. 2019. 


\section{APÊNDICES}

\section{APÊNDICE A - Ficha-Padrão para análise de decisões judiciais}

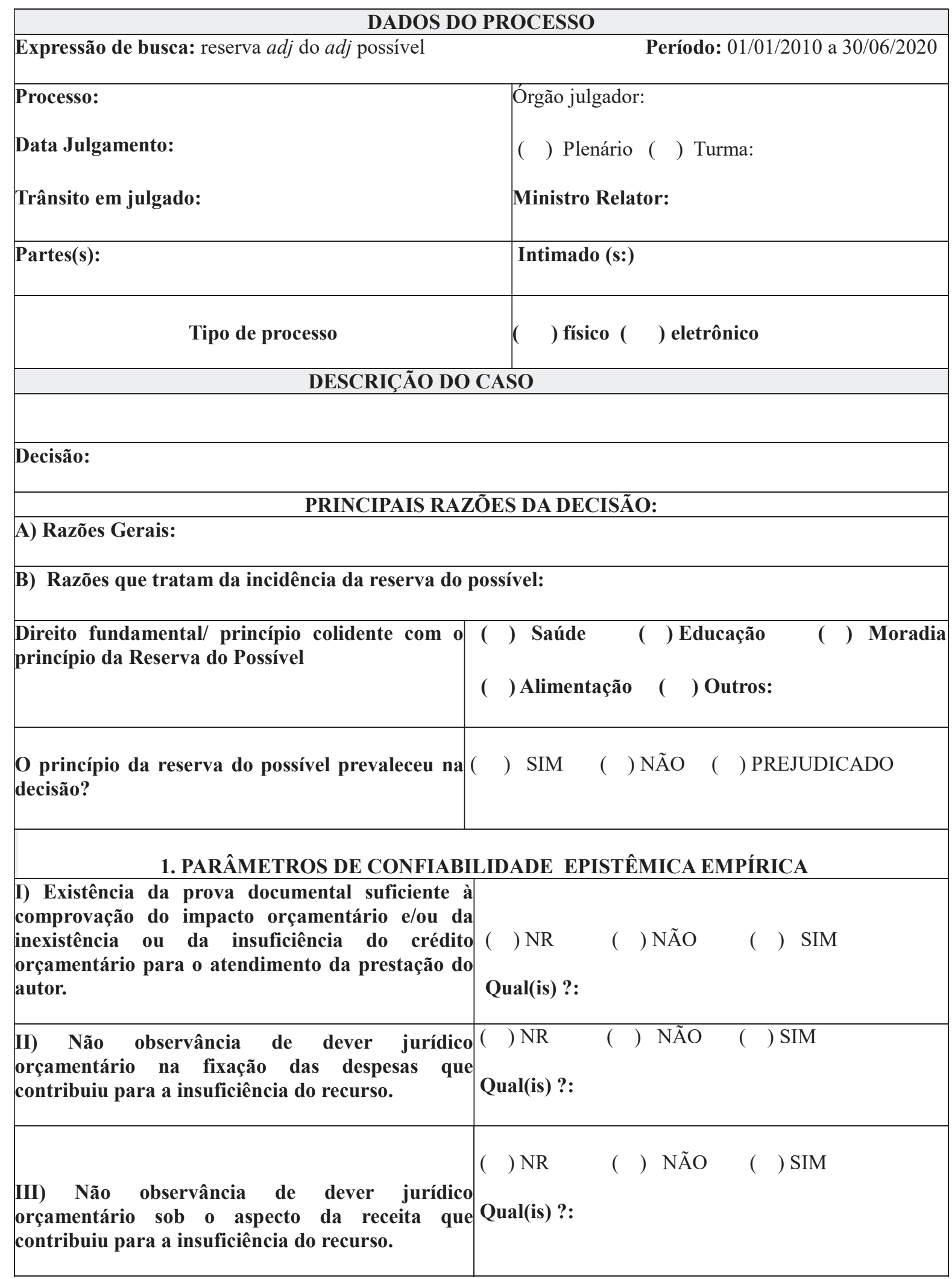




\begin{tabular}{|c|c|}
\hline $\begin{array}{l}\text { IV) Existe impossibilidade normativa de utilização } \\
\text { dos instrumentos de flexibilização orçamentária e } \\
\text { da reserva de contingência para a despesa que o } \\
\text { autor pleiteia? }\end{array}$ & $\begin{array}{l}\text { ( ) NR ( ) NÃO （ ) SIM } \\
\text { Qual(is) ?: }\end{array}$ \\
\hline $\begin{array}{c}\text { Grau de confiabilidade sugerido às premissas } \\
\text { empíricas }\end{array}$ & $\begin{array}{l}\text { ( ) prejudicado ( ) não comprovado } \\
(\text { ) não evidentemente falso ( ) plausível } \\
\text { ( ) confiável ou certo }\end{array}$ \\
\hline \multicolumn{2}{|c|}{ 2. PARÂMETROS DE CONFIABILIDADE EPISTÊMICA NORMATIVA } \\
\hline $\begin{array}{l}\text { I) A alegação de insuficiência de recursos é oposta a( } \\
\text { prestações relativas ao mínimo existencial? }\end{array}$ & $\begin{array}{l}(\quad) \text { NR ( ) NÃO ( ) SIM } \\
\text { Qual(is) ? }\end{array}$ \\
\hline $\begin{array}{l}\text { II) Existe de decisão anterior do Tribunal ou } \\
\text { precedente que tenha estabelecido regra de } \\
\text { prevalência do princípio da reserva do possível, nas } \\
\text { mesmas condições, em relação ao mesmo princípio } \\
\text { colidente? }\end{array}$ & $\begin{array}{l}\text { ( ) NR ( ) NÃO （） SIM } \\
\text { Qual(is) ?: }\end{array}$ \\
\hline $\begin{array}{c}\text { Grau de confiabilidade sugerido às premissas } \\
\text { normativas }\end{array}$ & $\begin{array}{l}\text { ( ) prejudicado } \quad \text { ( ) não comprovado } \\
(\text { ) não evidentemente falso ( ) plausível } \\
\text { ( ) confiável ou certo }\end{array}$ \\
\hline
\end{tabular}

Fonte: elaborado pela própria autora (2021) 


\section{APÊNDICE B - Quadros da Tabulação cruzada quantitativa das decisões}

Quadro 1 - Tabulação cruzada - pesquisa jurisprudencial STF

TABULAÇAO CRUZADA - PESQUISA JURISPRUDENCIAL STF - RESERVA DO POSSIVEL

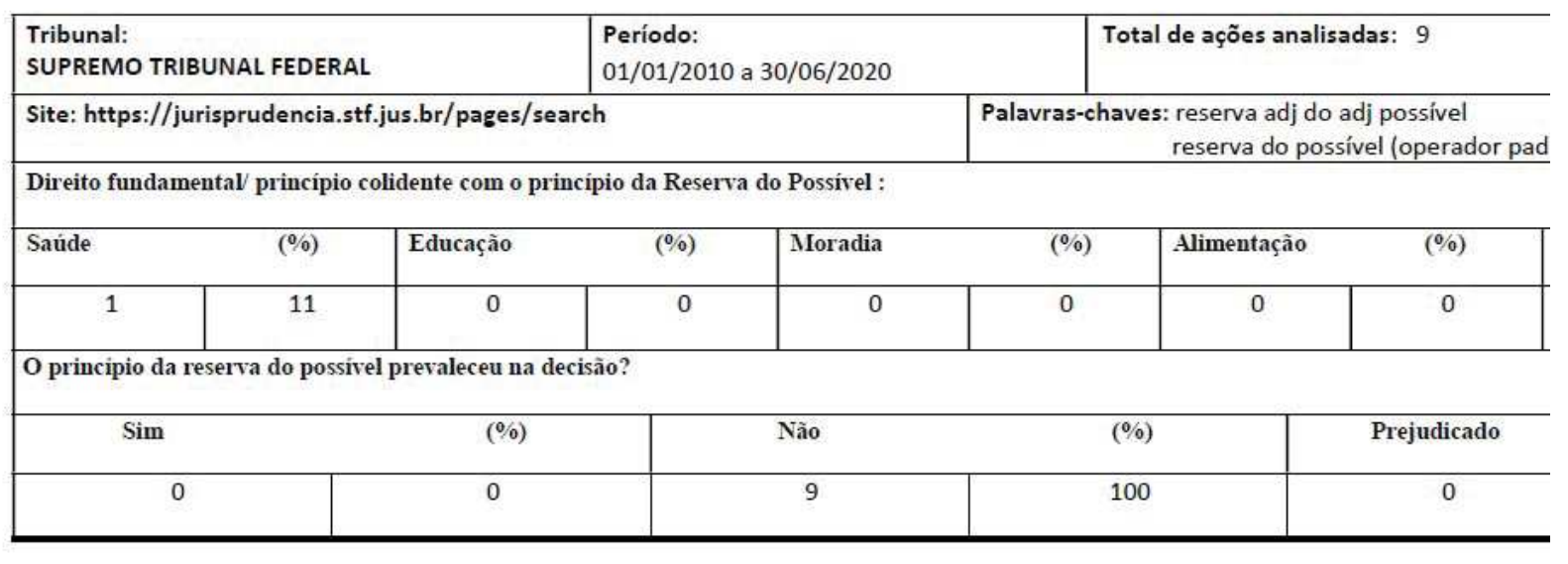

PARÂMETROS DE CONFIABILIDADE EPISTÊMICA EMPÍRICA

Existência da prova documental que comprove o impacto orçamentário e/ou da inexistência ou insuficiência do crédito orçamentário para o at

\begin{tabular}{|c|c|c|c|c}
\hline \multicolumn{2}{|c|}{$(\%)$} & Sim & (\%) & Não \\
\hline 3 & 33 & 0 & 0 & 6 \\
\hline
\end{tabular}

Não observância de dever jurídico orçamentário em relação à fixação das despesas que contribuiu para a insuficiência do recurso.

\begin{tabular}{|c|c|c|c|cc}
\hline \multicolumn{2}{|c|}{$(\%)$} & \multicolumn{2}{|c|}{$\operatorname{Sim}$} & $(\%)$ & Não \\
\hline 6 & 67 & 2 & 22 & $n$ \\
\hline
\end{tabular}

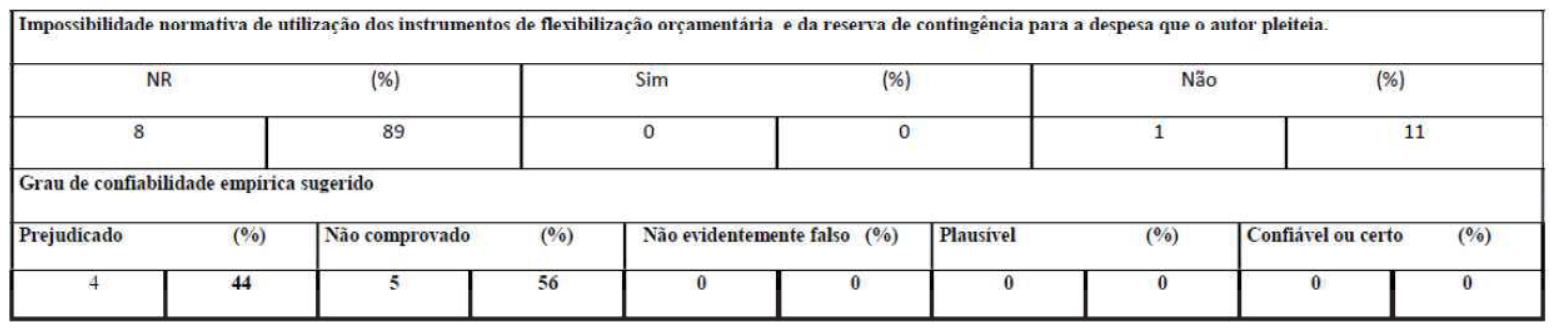

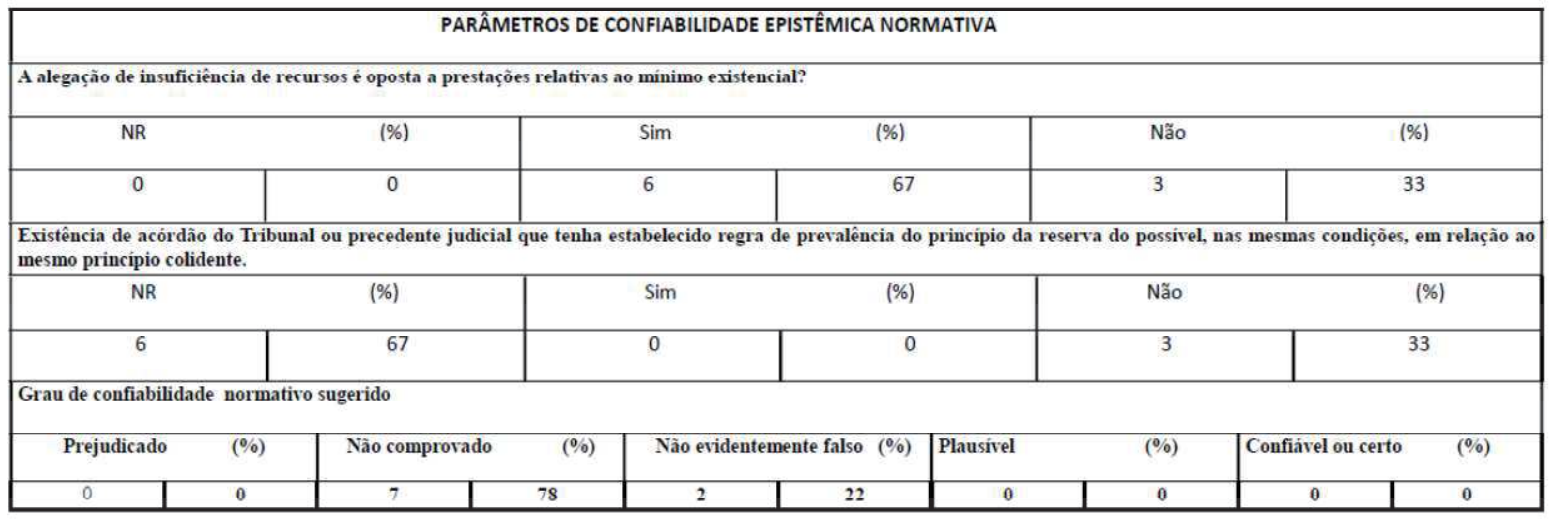

Fonte: elaborado pela autora (2021) 
Quadro 2 - Tabulação cruzada - pesquisa jurisprudencial STJ

\begin{tabular}{|c|c|c|c|c|c|c|c|c|c|}
\hline \multicolumn{5}{|c|}{$\begin{array}{l}\text { Tribunal } \\
\text { SUPERIOR TRIBUNAL DE JUSTIÇA }\end{array}$} & \multicolumn{3}{|c|}{$\begin{array}{l}\text { Período: } \\
\text { 01/01/2010 a 30/06/2020 }\end{array}$} & \multicolumn{2}{|c|}{ Total de ações analisadas: 15} \\
\hline \multicolumn{5}{|c|}{ Site: https://scon.sti.jus.br/SCON/ } & \multicolumn{5}{|c|}{$\begin{array}{l}\text { Palavas chaves: reserva adj do adj possivel } \\
\text { reserva do possivel (operador padrão: adj) }\end{array}$} \\
\hline \multicolumn{10}{|c|}{ Direito fundamental/ principio colidente com o principio da Reserva do Possivel } \\
\hline Saúde & (\%) & Educação & (\%) & Moradia & $(\%)$ & Alimentaç & (\%) & Outros & (\%) \\
\hline 4 & 27 & 5 & 33 & 0 & 0 & 0 & 0 & 6 & 40 \\
\hline \multicolumn{10}{|c|}{ O princípio da reserva do possivel prevaleceu na decisão? } \\
\hline \multirow{2}{*}{\multicolumn{2}{|c|}{ Sim }} & $(\%)$ & Não & & \multicolumn{2}{|l|}{ (\%) } & Prejudicado & \multicolumn{2}{|c|}{$(\%)$} \\
\hline & & 0 & & 15 & 100 & & 0 & ) & 0 \\
\hline
\end{tabular}

PARÂMETROS DE CONFIABILIDADE EPISTÊMICA EMPÍRICA

Existência da prova documental que comprove o impacto orçamentário e/ou da inexistência ou insuficiência do crédito orçamentário para o atendimento da prestação do autor.

\begin{tabular}{|c|c|c|c|c|c|}
\hline NR & (\%) & Sim & (\%) & Não & (\%) \\
\hline 9 & 60 & 0 & 0 & 6 & 40 \\
\hline \multicolumn{6}{|c|}{ Não observância de dever jurídico orçamentário em relação à fixação das despesas que contribuiu para a insuficiência do recurso. } \\
\hline NR & (\%) & Sim & (\%) & Não & (\%) \\
\hline 15 & 100 & 0 & 0 & 0 & 0 \\
\hline \multicolumn{6}{|c|}{ Não observância de dever jurídico orçamentário sob o aspecto da receita que contribuiu para a insuficiência do recurso } \\
\hline NR & (\%) & Sim & (\%) & Não & (\%) \\
\hline 15 & 100 & 0 & 0 & 0 & 0 \\
\hline
\end{tabular}

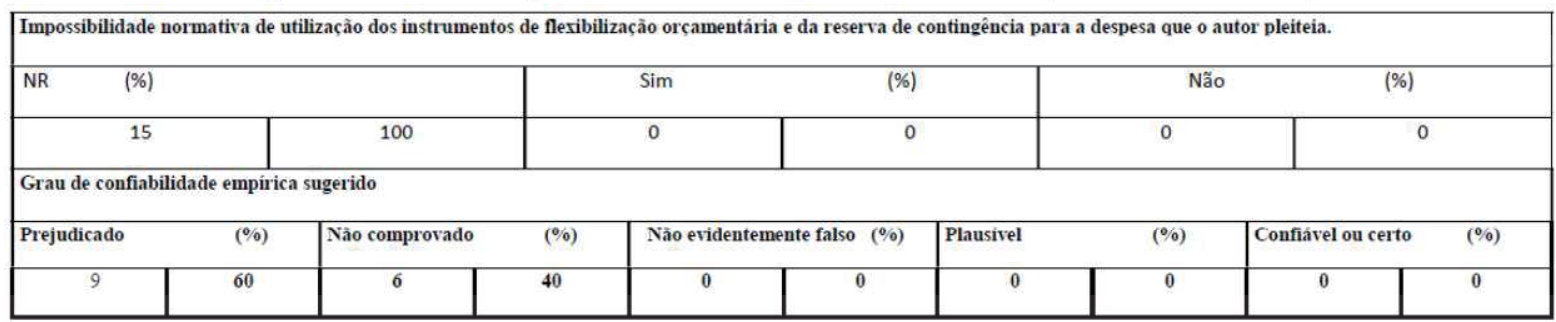

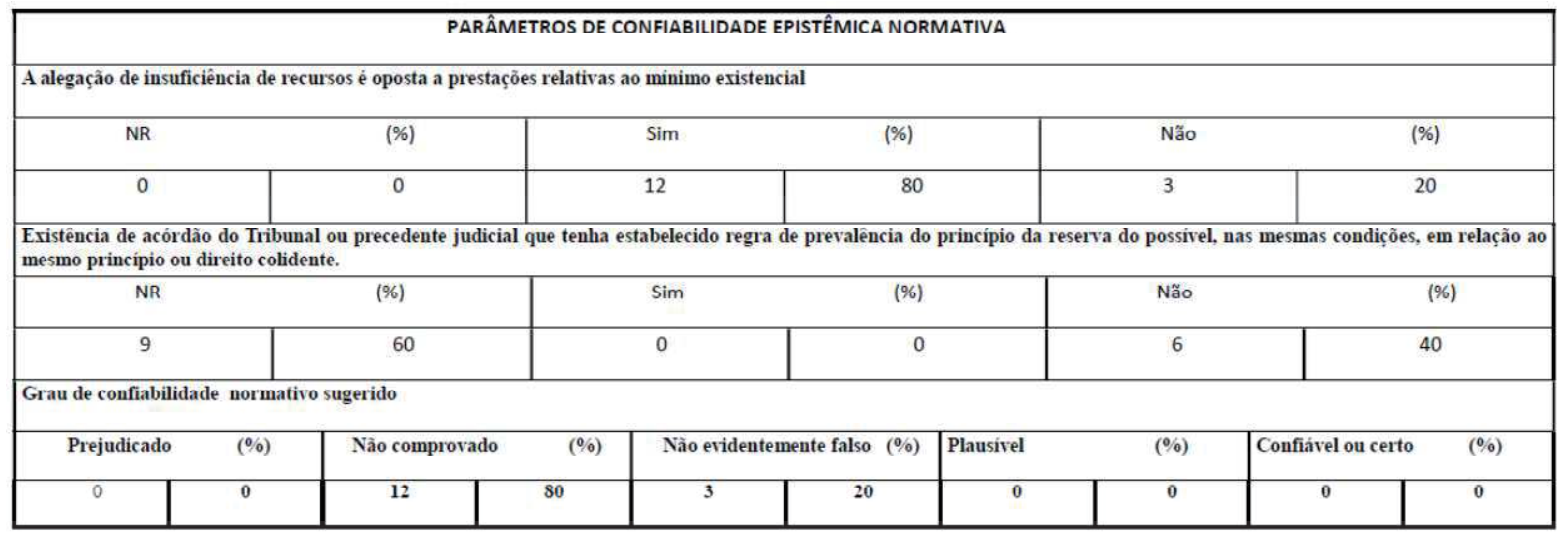

Fonte: elaborado pela autora (2021) 


\title{
APÊNDICE C - Exemplos de fichas de análise de acórdãos no âmbito do STF
}

\author{
Ficha 1 - Análise do acórdão do RE nº $592.581 /$ RS
}

\begin{tabular}{|c|c|}
\hline \multicolumn{2}{|c|}{ DADOS DO PROCESSO } \\
\hline Expressão de busca: reserva adj do adj possível & Período: 01/01/2010 a 30/06/2020 \\
\hline $\begin{array}{l}\text { Processo nº: Recurso Extraordinário } 592.581 / \text { RS } \\
\text { Repercussão Geral: Tema no } 220 \\
\text { Data Julgamento: } 13 / 08 / 2015 \\
\text { Trânsito em julgado: n/i (opostos embargos de declaração } \\
\text { ainda não julgados - conclusos para o relator em } \\
02 / 12 / 2020)\end{array}$ & $\begin{array}{l}\text { Òrgão Julgador: STF } \\
\text { ( X ) Plenário （ ）Turma: } \\
\text { Ministro Relator: Min. Ricardo Lewandowski }\end{array}$ \\
\hline $\begin{array}{l}\text { Partes(s): } \\
\text { Reclamante: Ministério Público do Estado do Rio Grande } \\
\text { do Sul } \\
\text { Reclamado: Estado do Rio Grande do Sul }\end{array}$ & $\begin{array}{l}\text { Intimado (s:) } \\
\text { Amici Curiae : } \\
\text { - União } \\
\text { - Distrito Federal } \\
\text { - Estado do Santa Catarina; Estado do Amapá; } \\
\text { Estado do Acre; Estado de Minas Gerais; Estado do } \\
\text { Roraima; Estado do Piauí; Estado do Amazonas; } \\
\text { Estado da Rondônia; Estado da Bahia; Estado do } \\
\text { Espírito Santo; Estado de São Paulo; Estado do } \\
\text { Pará; Estado do Pará; Estado do Mato Grosso do Sul }\end{array}$ \\
\hline Tipo de processo: & $\begin{array}{l}\text { ( ) físico ( } \mathbf{x} \text { ) eletrônico * (existem peças e } \\
\text { documentos com acesso restrito) }\end{array}$ \\
\hline
\end{tabular}

Recurso extraordinário interposto pelo Ministério Público Federal contra acórdão exarado pelo Tribunal de Justiça do Rio Grande do Sul que reformou decisão de primeiro grau aduzindo como razão para a reforma que "não compete ao Judiciário determinar ao Executivo a realização de obras em estabelecimento prisional, sob pena de indevida e invasão de campo decisório reservado à Administração Pública". Por outro lado, "o próprio Tribunal de Justiça reconheceu "que a precariedade das condições a que estão submetidos os detentos do Albergue Estadual de Uruguaiana, constitui violação de sua integridade física e moral, vedada, como se sabe, pela Constituição da República". (p.5)

A controvérsia central deste recurso extraordinário foi definida pelo relator no sentido de definir "se cabe ao Judiciário impor à Administração Pública a obrigação de fazer, consistente na execução de obras em estabelecimentos prisionais, a fim de garantir a observância dos direitos fundamentais de pessoas sob custódia temporária do Estado [...]”. (p.9)

Dispositivos constitucionais invocados: art. $1^{\circ}$, III e $5^{\circ}$, XLIX, da Constituição Federal.

Decisão: "Vistos, relatados e discutidos estes autos, acordam os Ministros do Supremo Tribunal Federal, em Sessão Plenária, sob a Presidência do Senhor Ministro Ricardo Lewandowski, na conformidade da ata de julgamentos e das notas taquigráficas, por unanimidade e nos termos do voto do Relator, apreciando o tema 220 da repercussão geral, dar provimento ao recurso extraordinário para cassar o acórdão recorrido, a fim de que se mantenha a decisão proferida pelo juízo de primeiro grau".

Ainda, por unanimidade, assentou-se a seguinte tese: “É lícito ao Judiciário impor à Administração Pública obrigação de fazer, consistente na promoção de medidas ou na execução de obras emergenciais em estabelecimentos prisionais para dar efetividade ao postulado da dignidade da pessoa humana e assegurar aos detentos o respeito à sua integridade física e moral, nos termos do que preceitua o art. $5^{\circ}$, XLIX, da Constituição Federal, não sendo oponível à decisão o argumento da reserva do possível nem o princípio da separação dos poderes". Ausente, justificadamente, o Ministro Teori Zavascki" (p.3). 
A) Razões Gerais:

A1) Foi reconhecido que "a situação em que se acha o Albergue Estadual de Uruguaiana é efetivamente atentatória à integridade física e moral de seus detentos. E não foi objeto de controvérsia nos autos "a afirmação segundo a qual os detentos estão permanentemente expostos a risco de morte em razão das péssimas condições da fiação elétrica do citado Albergue, havendo notícia, inclusive, de que um dos presos perdeu a vida por eletrocussão" (p.10), "os telhados caindo, umidade, esgoto a céu aberto" (Min. Ricardo Lewandowski, p.64).

A2) Contrariamente ao sustentado pelo acórdão recorrido, não se está diante de normas meramente programáticas e não se trata de hipótese na qual o Judiciário estaria ingressando indevidamente em seara reservada à Administração Pública. (Min. Ricardo Lewandowski, p.33)

A3) No caso dos autos, trata-se de "violação a direitos fundamentais, praticada pelo próprio Estado contra pessoas sob sua guarda, cumprindo ao Judiciário, por dever constitucional, oferecer-lhes a devida proteção". (Min. Ricardo Lewandowski, p.33)

A4) "Existe todo um complexo normativo de índole interna e internacional, que exige a pronta ação do Judiciário para recompor a ordem jurídica violada, em especial para fazer valer os direitos fundamentais - de eficácia plena e aplicabilidade imediata - daqueles que se encontram, temporariamente, repita-se, sob a custódia do Estado" (p.45).

A5) "A reiterada omissão do Estado brasileiro em oferecer condições de vida minimamente digna aos detentos exige uma intervenção enérgica do Judiciário para que, pelo menos, o núcleo essencial da dignidade da pessoa humana lhes seja assegurada, não havendo margem para qualquer discricionariedade por parte das autoridades prisionais no tocante a esse tema" (Min. Ricardo Lewandowski, p.45).

A6) A intervenção judicial neste caso vai além de determinar a mera execução de uma obra para garantia da incolumidade física. Visa a impedir um excesso de execução, que "na realidade nada mais é do que a expressão do inaceitável comportamento ilícito do Estado na execução da pena, autoriza a intervenção judicial" (Min. Celso de Mello, p.60).

A7) $\mathrm{O}$ direito previsto no art. 5 XLIX impõe uma conduta ao Estado que possui parâmetros legais infraconstitucionais nítidos, precisos e não são novos (Min. Edson Fachin, p.83).

A8) No caso, não há "qualquer abuso, ou desvio, ou violação eventual da separação dos poderes na espécie. A legislação da execução penal já define as condições básicas dessa execução. Está evidente, portanto, a sistemática violação" (Min. Gilmar Mendes, p.119).

A9) “O Judiciário não está assumindo as tarefas típicas do Poder Executivo, da Administração Pública, mas está determinando que se tomem medidas no sentido de estabelecer aquilo que decorre ou está previsto no Texto Constitucional [...] que foi amplamente densificado na legislação infraconstitucional. Portanto, a rigor, o que nós temos aqui são atos concretos ou omissões manifestas que desviam claramente da política que foi estabelecida de forma inequívoca por quem tem legitimidade democrática para fazê-lo, o próprio legislador" (Min. Gilmar Mendes, p.121).

\section{B) Razões que tratam da incidência da reserva do possível:}

B1) No voto do relator consigna-se que a hipótese dos autos não cuida "de implementação direta, pelo Judiciário, de políticas públicas, amparadas em normas programáticas, supostamente abrigadas na Carta Magna, em alegada ofensa ao princípio da reserva do possível” (Min. Ricardo Lewandowski,, p.45)

B2) Constatou-se grave omissão por partes das autoridades responsáveis pelo sistema prisional, uma vez que foi constatado que "verbas para melhorá-lo não faltam". O relator relatou que no sítio eletrônico do Ministério da Justiça, constava que, no âmbito federal, na principal fonte de recursos para financiamento das atividades de modernização e aprimoramento dos presídios brasileiros (Fundo Penitenciário Nacional - FUNPEN), gerido 
pelo Departamento Penitenciário Nacional - DEPEN/MJ constava até junho de 2015, o montante de R\$ 2.324.710.885,64 (dois bilhões, trezentos e vinte e quatro milhões, setecentos e dez mil,oitocentos e oitenta e cinco reais e sessenta e quatro centavos). Contudo, até 2013, foram utilizados pouco mais de $\mathrm{R} \$$ 357.200.572,00 (trezentos e cinquenta e sete milhões, duzentos mil e quinhentos e setenta e dois reais). Para o relator, isso se deveu "de um lado, em virtude do contingenciamento de verbas do Fundo, e, de outro, em face da inconsistência, mora ou falha na execução dos projetos concebidos pelos entes federados", demonstrando não haver "vontade política para resolver esse problema". (Min. Ricardo Lewandowski,, p.50 e p.64)

B3) "Contraproducente se revela a alegação da reserva do possível, pois o Estado não pode se furtar a garantir, minimamente, o conteúdo normativo dos direitos especificados ao longo do Texto Constitucional e exaustivamente regulamentado pelas normas infraconstitucionais, sob pena de incorrer em ilegitimidade" (Min. Edson Fachin, p. 90)

B4) "A reserva do possível não pode servir de argumento para escusar o Estado de cumprir os comandos constitucionais, sobretudo aqueles expressamente nomeados e caracterizados como direitos fundamentais" [...] "Eventual objeção orçamentária deveria ser acompanhada de prova expressa, documental, que justifique adequadamente e demonstre a impossibilidade financeira do Estado, bem como porque as escolhas políticogovernamentais deixaram de atender demanda tão fundamental. A invocação da reserva do possível não pode consistir em mera alegação que isenta, por si só, o Estado de suas obrigações. Somente justo motivo, objetivamente aferido, tem tal valia" ( idem, p.91)

B5) "a inexistência de recursos no orçamento vigente - demonstrável objetivamente - não afasta a possibilidade de atendimento do direito em tela. Nesta perspectiva, é possível a inclusão da respectiva dotação no orçamento do ano seguinte (art. 165, § 5 , c/c art. 167, I, ambos da Constituição da República)". (idem, p.92)

B6) "não se pode invocar de forma longínqua a reserva do financeiramente possível para impedir ou bloquear uma determinação judicial no sentido do reparo que se exige, para que se deem condições mínimas de funcionalidade, de funcionamento à unidade prisional”. (Min. Gilmar Mendes, p.119).

B7) “[...] não pode o poder público, simplesmente, dizer que, tendo em vista as decisões políticas que ele próprio tomou, que ele fez alocação de recursos para aquela finalidade e não para aquela outra, que ele agora pode invocar simplesmente a reserva do financeiramente possível para se isentar de responsabilidades tão elementares. [...] Mas é preciso, inclusive, quando se invoque aí o limite do financeiramente possível, que haja a própria noção de transparência desses números" (Min. Gilmar Mendes, p.122).

\begin{tabular}{|c|c|c|}
\hline $\begin{array}{l}\text { Direito fundamental/ princípio colidente } \\
\text { com o princípio da Reserva do Possível }\end{array}$ & \multicolumn{2}{|c|}{$\begin{array}{l}\text { ( ) Saúde ( ) Educação ( ) Moradia } \\
\text { ( ) Alimentação } \quad(\mathbf{x}) \text { Outros: O direito fundamental de } \\
\text { proteção à integridade física e moral dos presos (art. 50, XLIX) }\end{array}$} \\
\hline $\begin{array}{l}\text { O princípio da reserva do possível } \\
\text { prevaleceu na decisão? }\end{array}$ & $(\quad) \mathrm{SII}$ & M ( $\mathrm{X}) \mathrm{NÃO} \quad(\quad)$ PREJUDICADO \\
\hline \multicolumn{3}{|c|}{ 1. PARÂMETROS DE CONFIABILIDADE EPISTÊMICA EMPÍRICA } \\
\hline $\begin{array}{l}\text { I) Existência da prova documental suf } \\
\text { comprovação do impacto orçamentário } \\
\text { inexistência ou da insuficiência do } \\
\text { orçamentário para o atendimento da pres } \\
\text { autor. }\end{array}$ & $\begin{array}{l}\text { iciente à } \\
\text { e/ou da } \\
\text { crédito } \\
\text { tação do }\end{array}$ & $\begin{array}{l}(\quad) \text { NR } \quad(\quad) \text { SIM } \\
\text { Qual(is) ?: }\end{array}$ \\
\hline $\begin{array}{l}\text { II) Não observância de dever } \\
\text { orçamentário em relação à fixação das } \\
\text { que contribuiu para a insuficiência do rec }\end{array}$ & $\begin{array}{l}\text { jurídico } \\
\text { despesas } \\
\text { urso. }\end{array}$ & $\begin{array}{l}(\quad) \text { NR }(\quad \text { NÃO ( } \mathrm{x}) \text { SIM } \\
\text { Qual(is) ?: Contingenciamento indevido dos recursos } \\
\text { do FUNPEN }\end{array}$ \\
\hline
\end{tabular}




\begin{tabular}{|c|c|}
\hline $\begin{array}{l}\text { III) Não observância de dever jurídico } \\
\text { orçamentário sob o aspecto da receita que } \\
\text { contribuíram para a insuficiência do recurso. }\end{array}$ & $\begin{array}{lll}(\mathrm{x}) \mathrm{NR} & (\quad) \text { NÃO } & (\text { ) SIM } \\
\text { Qual(is) ?: } & & \end{array}$ \\
\hline $\begin{array}{l}\text { IV) Impossibilidade normativa de utilização dos } \\
\text { instrumentos de flexibilização orçamentária (como } \\
\text { créditos especiais, créditos suplementares, } \\
\text { transposição e remanejamentos) e da reserva de } \\
\text { contingência para a despesa que o autor pleiteia }\end{array}$ & 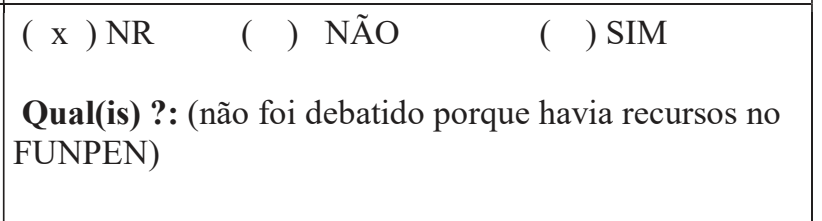 \\
\hline Grau de confiabilidade empírica sugerido & 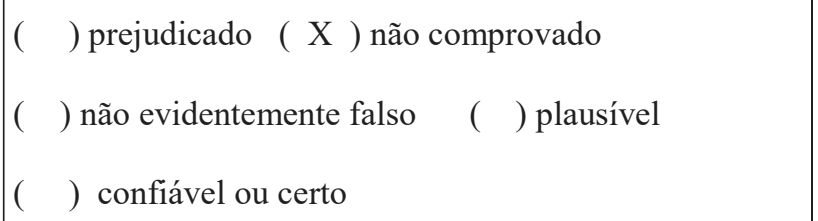 \\
\hline \multicolumn{2}{|c|}{ 2. PARÂMETROS DE CONFIABILIDADE EPISTÊMICA NORMATIVA } \\
\hline $\begin{array}{l}\text { I) A alegação de insuficiência de recursos obsta } \\
\text { prestações relativas ao mínimo existencial }\end{array}$ & 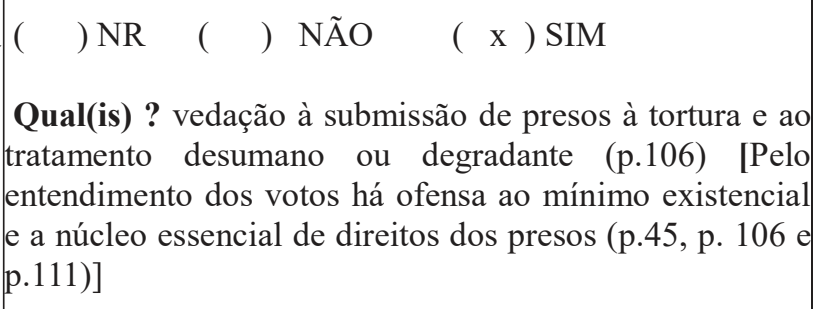 \\
\hline $\begin{array}{l}\text { II) Existência de acórdão do Tribunal ou } \\
\text { precedente judicial que tenha estabelecido regra de } \\
\text { prevalência do princípio da reserva do possível, nas } \\
\text { mesmas condições, em relação ao mesmo princípio } \\
\text { colidente. }\end{array}$ & $\begin{array}{l}\text { ( ) NR ( } \mathrm{x} \text { ) NÃO ( ) SIM } \\
\text { Qual(is) ?: } \\
\text { Obs: os precedentes citados não davam precedência à } \\
\text { reserva do possível mas a direitos que compõe o mínimo } \\
\text { existencial. Uma decisão monocrática foi citada } \\
\text { especificamente que confrontava o principio da reserva } \\
\text { do possível com os direitos dos presos extraída da ADPF } \\
\text { 45-MC/DF, Rel. Min. Celso de Mello. }\end{array}$ \\
\hline Grau de confiabilidade normativo sugerido & $\begin{array}{l}\left(\begin{array}{l}\text { ) prejudicada } \quad(\mathrm{x}) \text { não comprovado } \\
(\end{array}\right) \text { não evidentemente falso } \\
\left(\begin{array}{ll}\text { ) plausível } & (\mathrm{)}) \text { confiável ou certo }\end{array}\right.\end{array}$ \\
\hline
\end{tabular}

\section{Observações:}

1) Sobre a ponderação e a reserva do possível afirmou o Ministro Luiz Fux: "Então, numa ponderação entre a reservado possível e obras emergenciais, que vão atentar para o centro de gravidade da Constituição Federal, que é a dignidade da pessoa humana, há de preponderar efetivamente essa proteção à dignidade com realização de obras emergenciais que não possam ser obstadas por uma vã alegação de reserva do possível” (p.93).

2) O Ministro Barroso chama a atenção para que "não é a reserva do possível um aspecto suficiente para postergar obrigações que envolvam o núcleo essencial dos direitos fundamentais, aos quais corresponde a dignidade da pessoa humana" (p.98). [Trata-se de um exemplo de decisão que não cita apenas o mínimo existencial como limite à reserva do possível, mas inclui o núcleo essencial dos direitos fundamentais em geral]. 
3) O Min. Luiz Fux cita o entendimento do Doutor Felipe de Melo Fonte na obra sobre Políticas Públicas de Direitos Fundamentais. "E, exatamente, ao abordar a questão dos presos, em relação ao mínimo existencial, ele assenta que, nesses casos, a regra constitucional que veda a submissão à tortura e ao tratamento desumano ou degradante é exatamente aquela que deve ser observada quando se tem em mente o mínimo existencial; ou seja, o mínimo existencial é não deixar que o preso seja tratado de forma desumana ou degradante, tal como prevê a Constituição Federal" (p.106).

4) Os Ministros consideram o contingenciamento dos recursos do FUNPEN como constrangedor". O Estado baseia em alegação de insuficiência de recursos por ele causada - p.123). Foi relatado pela AGU sobre o não cumprimento dos convênios celebrados entre Estados e União para repasse dos recursos do FUNPEN, inclusive de desvio de verba para aplicações diversas do objeto do convênio (p.62).

Ficha 2 - Análise do acórdão do RE n ${ }^{0}$ 553.710/ DF

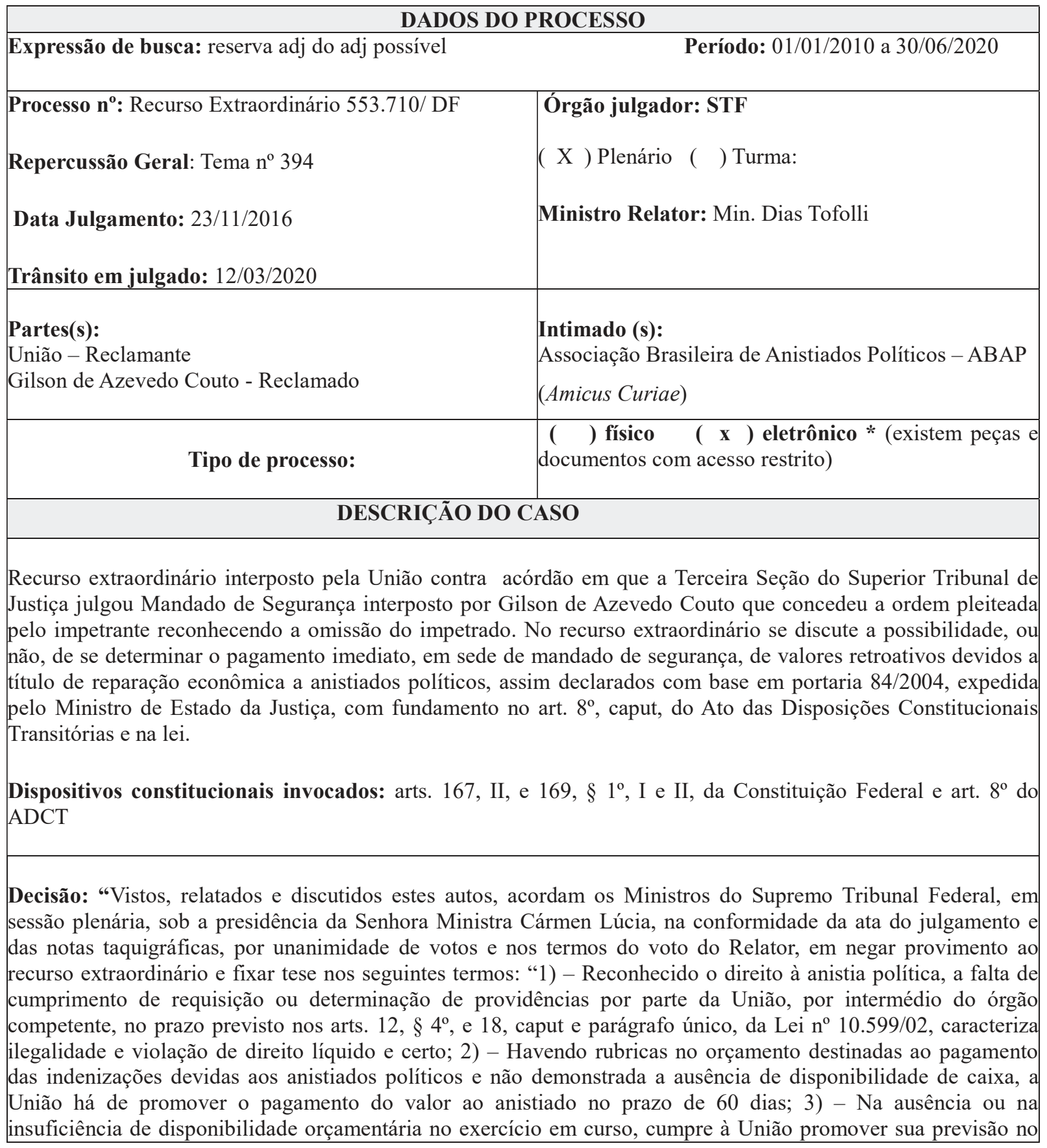


projeto de lei orçamentária imediatamente seguinte”. (p.3)

\section{PRINCIPAIS RAZÕES DA DECISÃO}

\section{A) Razões Gerais:}

A.1) Declarado anistiado político por portaria 84/2004 do Ministro de Estado da Justiça, a falta de cumprimento da determinação de providências por parte da União, por intermédio do Ministério competente, no prazo previsto no parágrafo único do art. 18 da Lei $n^{\circ}$ 10.599/2002 caracteriza omissão ilegal e violação de direito líquido e certo. (p.1)

A.2) $\mathrm{O}$ art. $12, \S 4^{\circ}$, da Lei $\mathrm{n}^{\circ} 10.559 / 2002$ tornou vinculante a decisão administrativa ao estabelecer que "as requisições e decisões proferidas pelo Ministro de Estado da Justiça nos processos de anistia política serão obrigatoriamente cumpridas no prazo de sessenta dias, por todos os órgãos da Administração Pública e quaisquer outras entidades a que estejam dirigidas". A obrigação existe, inclusive houve na espécie a inclusão no orçamento das despesas decorrentes da decisão administrativa vinculante. (p.2)

A.3) O direito líquido e certo do impetrante já foi reconhecido por portaria específica que declarou sua condição de anistiado, sendo, então, fixado valor que lhe era devido, de cunho indenizatório. O que se tem é uma obrigação de fazer por parte da União que está sendo descumprida (p.2).

A.4) Não se aplica o regime jurídico do art. 100 da Constituição Federal se a Administração Pública reconhece, administrativamente, que o anistiado possui direito ao valor decorrente da concessão da anistia. A dívida da Fazenda Pública não foi reconhecida por meio de uma decisão do Poder Judiciário (p.2).

A.5) A jurisprudência desta Suprema Corte consolidou a premissa de que a existência de dotação legal é suficiente para que haja o cumprimento integral da portaria que reconhece a condição de anistiado político, conforme o art. $12, \S 4^{\circ}$, da Lei $\mathrm{n}^{\mathrm{o}} 10.559 / 02$. Demonstrada, portanto, a existência de dotação orçamentária, decorrente de presumida legítima programação financeira pela União, não se visualiza, no presente caso, afronta ao princípio da legalidade da despesa pública ou às regras constitucionais que impõem limitações às despesas de pessoal e concessões de vantagens e benefícios pessoais (Min. Dias Toffoli, p. 19).

A.6) Não é possível condicionar o pagamento de valores retroativos devidos a anistiado político à existência de termo de adesão firmado pelo anistiado (RMS 27.094, Rel. Min. Dias Toffoli), que constitui mera faculdade do anistiado (Min. Dias Toffoli, p.23).

\section{B) Razões que tratam da incidência da reserva do possível:}

B.1) A inexistência de recursos deve ser real, demonstrada de forma esclarecedora. Não basta que a União alegue que as decisões judiciais poderão levar a Administração à exaustão orçamentária. A exaustão já deve estar presente, a indisponibilidade de caixa deve ser situação presente e não mera possibilidade futura, o que deve ser analisado em cada caso. "Portanto, como havia rubricas no orçamento destinadas ao pagamento das indenizações devidas aos anistiados políticos e não foi demonstrada a ausência de disponibilidade de caixa, a União há de promover o pagamento imediato do valor ao recorrido, não havendo que se falar em observância ao regime dos precatórios. Tampouco se poderia cogitar, no caso concreto, de se determinar a inclusão da dívida reconhecida no orçamento para o próximo ano, na medida em que a mora já se operou e pagamentos foram realizados a terceiros durante os anos em que o anistiado deixou de ter atendido seu crédito.” (p.37) Não se reconheceu a aplicação da reserva do possível por haver prova de destinação orçamentária suficiente para o pagamento do valor correspondente à indenização (p.67).

B.2) $\mathrm{O}$ caso refere-se à existência de direito líquido e certo individual de percepção dos retroativos, nos termos do direito vigente, afastando a incidência da reserva do possível. (Min Dias Toffoli, p.24)

\begin{tabular}{|c|c|}
\hline Direit & $\begin{array}{lll}\text { ( ) Saúde } & \text { ( ) Educação } & (\text { ) Moradia } \\
\text { ( ) Alimentação } & (\mathrm{x}) \text { Outros: direito líquido e certo }\end{array}$ \\
\hline
\end{tabular}




\begin{tabular}{|c|c|}
\hline & $\begin{array}{l}\text { anistiado político ao recebimento de valores retroativos } \\
\text { referentes à prestação mensal legalmente reconhecida em } \\
\text { razão da existência de declaração da condição de anistiado } \\
\text { político militar. }\end{array}$ \\
\hline $\begin{array}{l}\text { O Princípio da reserva do possível prevaleceu na } \\
\text { decisão? }\end{array}$ & ( ) PREJUDICADO \\
\hline \multicolumn{2}{|c|}{ 1. PARÂMETROS DE CONFIABILIDADE EPISTÊMICA EMPÍRICA } \\
\hline \multicolumn{2}{|c|}{ 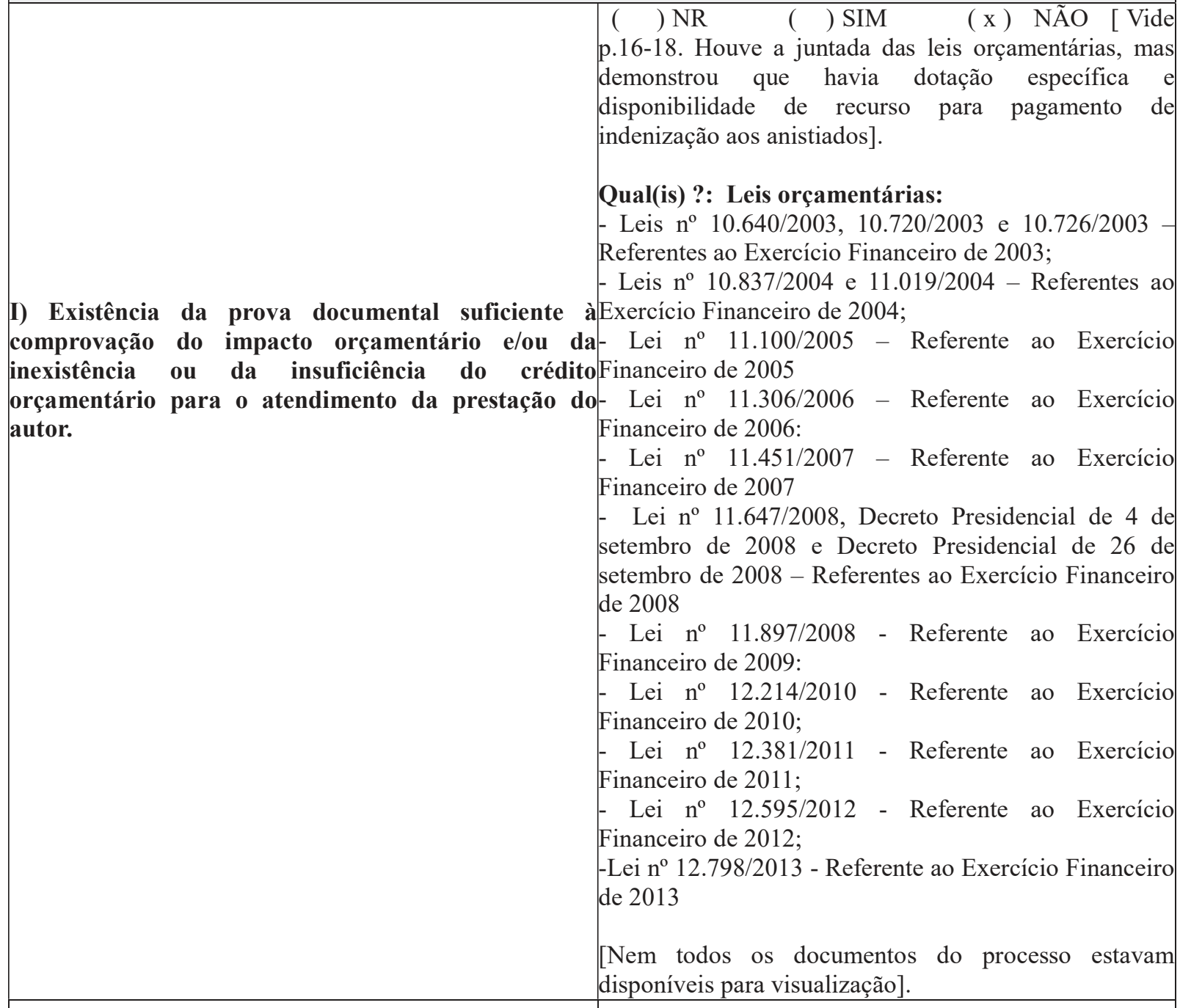 } \\
\hline $\begin{array}{l}\text { II) Não observância de dever jurídico orçamen } \\
\text { em relação à fixação das despesas que contri } \\
\text { para a insuficiência do recurso. }\end{array}$ & \begin{tabular}{l|l} 
( ) NR ( ) NÃO ( X ) SIM \\
itário \\
Qubuiul(is)?: o dever de planejar a inclusão no \\
exercício financeiro seguinte o passivo das \\
indenizações (p.41). [Desde 2010, no que se refere \\
aos anistiados militares e, desde 2012 , em relação a \\
todos aqueles submetidos ao regime especial do \\
anistiado político, verifica-se a ausência de previsão \\
nas leis orçamentárias da União de ação específica \\
voltada ao pagamento dos valores retroativos devidos \\
a título de reparação econômica, salvo para aqueles \\
que se submeteram, voluntariamente, ao regime de \\
parcelamento do pagamento mediante Termo de
\end{tabular} \\
\hline
\end{tabular}




\begin{tabular}{|c|c|}
\hline & $\begin{array}{l}\text { Adesão previsto na Lei } \mathrm{n}^{\circ} 11.354 / 2006 \text {. Na decisão } \\
\text { constou que: "verifica-se, portanto, grave omissão } \\
\text { ao dever de planejar ínsito à própria noção de } \\
\text { orçamento público [...]" (p.56 - negrito e itálico no } \\
\text { original)]. }\end{array}$ \\
\hline $\begin{array}{l}\text { III) Não observância de dever jurídico orçamentário } \\
\text { sob o aspecto da receita que contribuiu para a } \\
\text { insuficiência do recurso. }\end{array}$ & $\begin{array}{l}\text { ( x ) NR ( ) NÃO } \quad \text { ( ) SIM } \\
\text { Qual(is) ?: }\end{array}$ \\
\hline $\begin{array}{l}\text { IV) Impossibilidade normativa de utilização dos } \\
\text { instrumentos de flexibilização orçamentária e da } \\
\text { reserva de contingência para a despesa que o autor } \\
\text { pleiteia }\end{array}$ & $\begin{array}{l}\text { ( } \mathrm{x}) \mathrm{NR} \quad(\quad) \text { NÃO } \quad(\text { ) SIM } \\
\text { Qual(is) ?: }\end{array}$ \\
\hline Grau de confiabilidade empírica sugerido & $\begin{array}{l}(\text { ) prejudicada ( } \mathrm{x} \text { ) não comprovado } \\
(\quad) \text { não evidentemente falso ( ) plausível } \\
(\quad) \text { confiável ou certo }\end{array}$ \\
\hline \multicolumn{2}{|c|}{ 2. PARÂMETROS DE CONFIABILIDADE EPISTÊMICA NORMATIVA } \\
\hline $\begin{array}{l}\text { I) A alegação de insuficiência de recursos é oposta a } \\
\text { prestações relativas ao mínimo existencial }\end{array}$ & $\begin{array}{l}\quad \text { ) NR ( } x \quad \text { ) NÃO ( ) SIM } \\
\text { Qual(is) ? }\end{array}$ \\
\hline $\begin{array}{l}\text { II) Existência de acórdão do Tribunal ou precedente } \\
\text { judicial que tenha estabelecido regra de precedência } \\
\text { do princípio da reserva do possível, nas mesmas } \\
\text { condições, em relação ao mesmo princípio colidente. }\end{array}$ & 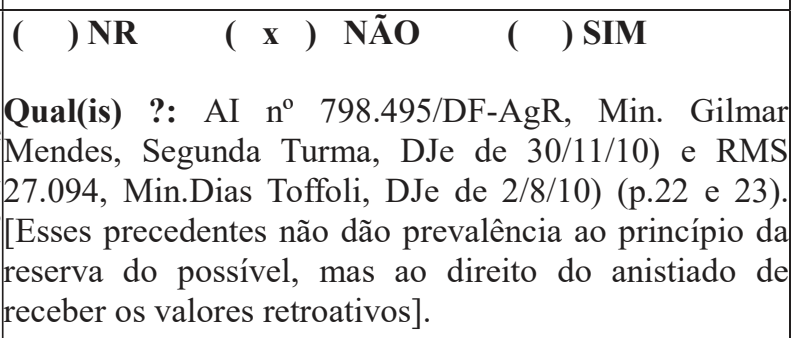 \\
\hline Grau de confiabilidade normativa sugerido & $\begin{array}{l}\text { ( ) prejudicada ( } \mathrm{x} \text { ) não comprovado } \\
\text { ( ) não evidentemente falso ( ) plausível } \\
(\quad \text { ) confiável ou certo }\end{array}$ \\
\hline
\end{tabular}

\section{Observações:}

1) A análise das leis orçamentárias foi detalhada no voto do Min. Edson Fachin (p. 55-56). No mesmo voto o Ministro Fachin afirma que:

a) "Mas estou sumariando para assentar que cabe à União o dever de pagar àqueles cujo direito restou reconhecido em exercício financeiro no qual se previu ação orçamentária para o pagamento de indenizações. E, quando menos portanto, quando não há previsão -, o dever de planejar a inclusão no exercício financeiro seguinte do passivo de indenizações posteriormente reconhecidas, a fim de abarcar o sentido de disponibilidade orçamentária previsto no artigo 12, parágrafo IV, da Lei ${ }^{\circ} 10.559 / 2002$ " (p.41).

b) "Na perspectiva de eventual ausência de disponibilidade financeira para fazer frente a tais despesas no exercício financeiro em curso, não se pode descurar que a própria Constituição da República previu a possibilidade de 
abertura de créditos adicionais suplementares e especiais, desde que respeitada a autorização legislativa e realizada a indicação dos recursos correspondentes (art. 167, V, CRFB)" (p.50).

c) "Perceba-se, portanto, que ao beneficiário da indenização concedida administrativamente com base na Lei $n^{\circ} 10.559 / 2002$ não cabe a realização de uma análise minudente da execução orçamentária a fim de provar a suficiência dos recursos alocados na lei orçamentária para o pagamento das indenizações aos anistiados políticos, grupo em que se inclui por ato do próprio Estado. Cabe-lhe, tão somente, comprovar a previsão no orçamento, sendo ônus da administração demonstrar, documentalmente, caso efetivamente tenha se perfectibilizado a insuficiência de recursos, a impossibilidade do pagamento, mesmo que tenha feito uso dos instrumentos constitucionais disponíveis (créditos adicionais) ou a impossibilidade de utilização desses, devendo fazer o adequado planejamento orçamentário para a liquidação desse passivo" (p.51- negrito e itálico no original). 


\section{APÊNDICE D - Exemplos de fichas de análise de acórdãos no âmbito do STJ}

Ficha 1 - Análise do acórdão do AgRg no AREsp 790.767/ MG

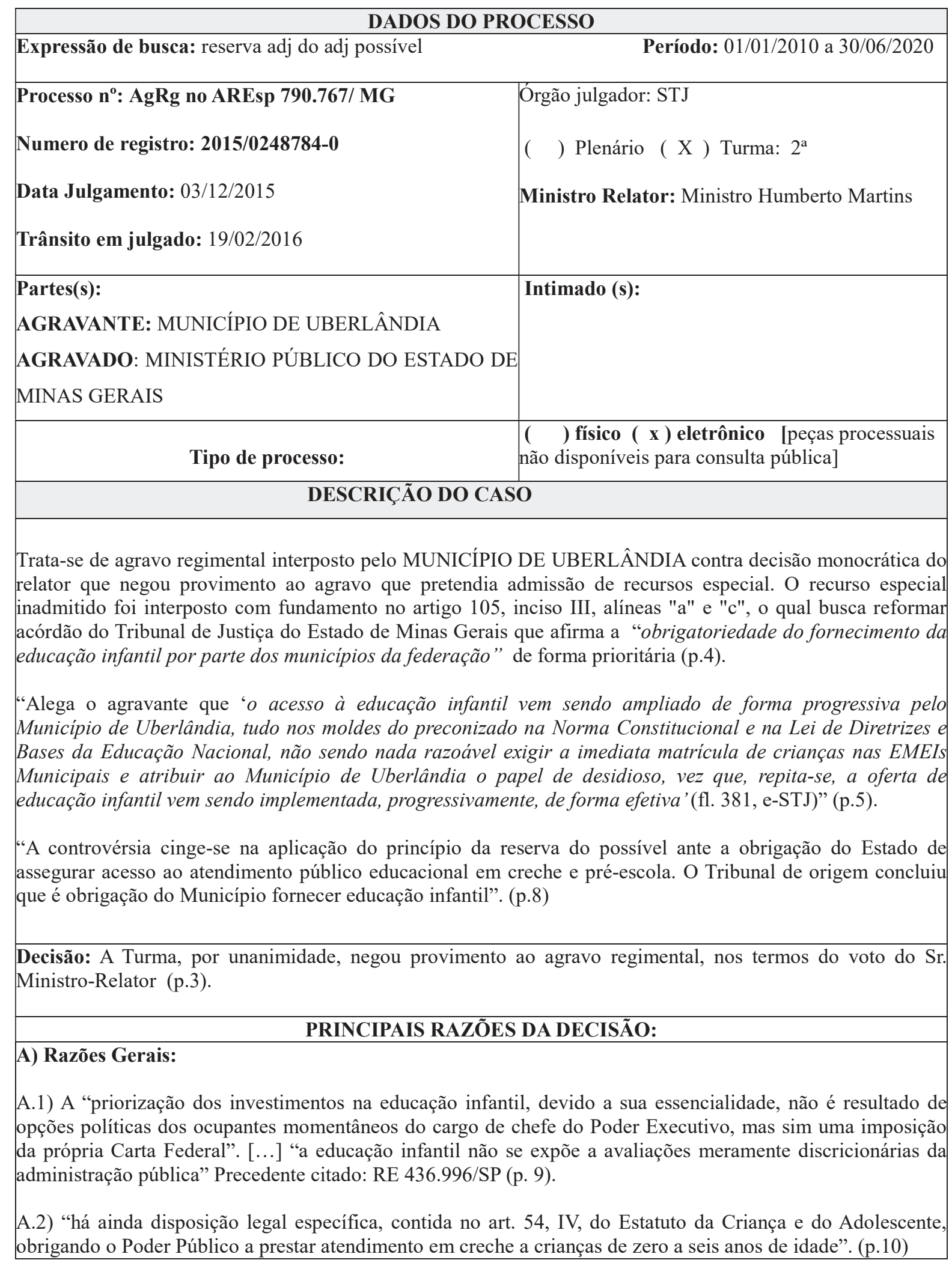


A.3) "O mínimo existencial não se resume ao mínimo vital, ou seja, o mínimo para se viver. O conteúdo daquilo que seja o mínimo existencial abrange também as condições socioculturais, que, para além da questão da mera sobrevivência, asseguram ao indivíduo um mínimo de inserção na 'vida' social”. (p.2)

A.4) “[...] dentre os direitos considerados prioritários, encontra-se o direito à educação. O que distingue o homem dos demais seres vivos não é a sua condição de animal social, mas sim de ser um animal político. É a sua capacidade de relacionar-se com os demais e, por meio da ação e do discurso, programar a vida em sociedade". (p.2)

A.5) "No espaço público, em que se travam as relações comerciais, profissionais, trabalhistas, bem como onde se exerce a cidadania, a ausência de educação, de conhecimento, em regra, relega o indivíduo a posições subalternas, o torna dependente das forças físicas para continuar a sobreviver e, ainda assim, em condições precárias.. Eis a razão pela qual o art. 227 da CF e o art. $4^{\circ}$ da Lei 8.069/90 dispõem que a educação deve ser tratada pelo Estado com absoluta prioridade. No mesmo sentido, o art. 54 do Estatuto da Criança e do Adolescente prescreve que é dever do Estado assegurar às crianças de zero a seis anos de idade o atendimento em creche e pré-escola. Portanto, o pleito do Ministério Público encontra respaldo legal e jurisprudencial. Precedentes: REsp 511.645/SP, Rel. Min. Herman Benjamin, Segunda Turma, julgado em 18.8.2009, DJe 27.8.2009; RE 410.715 AgR / SP - Rel. Min. Celso de Mello, julgado em 22.11.2005, DJ 3.2.2006, p. 76". (p.3)

\section{B) Razões que tratam da incidência da reserva do possível}

B.1) “observa-se que a dimensão fática da reserva do possível é questão intrinsecamente vinculada ao problema da escassez. Esta pode ser compreendida como 'sinônimo' de desigualdade. Bens escassos são bens que não podem ser usufruídos por todos e, justamente por isso, devem ser distribuídos segundo regras que pressupõe o direito igual ao bem e a impossibilidade do uso igual e simultâneo" (p.14).

B.2) "Esse estado de escassez, muitas vezes, é resultado de um processo de escolha, de uma decisão. Quando não há recursos suficientes para prover todas as necessidades, a decisão do administrador de investir em determinada área implica escassez de recursos para outra que não foi contemplada. A título de exemplo, o gasto com festividades ou propagandas governamentais pode ser traduzido na ausência de dinheiro para a prestação de uma educação de qualidade.”.(p.15) “Com efeito, o princípio da reserva do possível não pode ser oposto quando a escassez é resultado de um processo de escolha das atividades que serão atendidas - ao mínimo existencial, aos direitos que a própria Constituição Federal elege como prioritários, como é o caso do direito à educação infantil" (p.10).

B.3) "É por esse motivo que, em um primeiro momento, a reserva do possível não pode ser oposta à efetivação dos Direitos Fundamentais, já que, quanto a estes, não cabe ao administrador público preterí-los em suas escolhas. Nem mesmo a vontade da maioria pode tratar tais direitos como secundários. Isso porque a democracia não se restringe na vontade da maioria. O princípio do majoritário é apenas um instrumento no processo democrático, mas este não se resume àquele. Democracia é, além da vontade da maioria, a realização dos direitos fundamentais" (p.16).

B.4) "Com isso, observa-se que a realização dos Direitos Fundamentais não é opção do governante, não é resultado de um juízo discricionário nem pode ser encarada como tema que depende unicamente da vontade política. Aqueles direitos que estão intimamente ligados à dignidade humana não podem ser limitados em razão da escassez quando esta é fruto das escolhas do administrador. Não é por outra razão que se afirma que a reserva do possível não é oponível à realização do mínimo existencial” (p. 2).

B.5) “[...] mesmo com a alocação dos recursos no atendimento do mínimo existencial, persista a carência orçamentária para atender a todas as demandas. Nesse caso, a escassez não seria fruto da escolha de atividades não prioritárias, mas sim da real insuficiência orçamentária. Em situações limítrofes como essa, não há como o Poder Judiciário imiscuir-se nos planos governamentais, pois estes, dentro do que é possível, estão de acordo com a Constituição, não havendo omissão injustificável”. (p.8)

B.6) "Ressalte-se que a real insuficiência de recursos deve ser demonstrada pelo Poder Público, não sendo admitido que a tese seja utilizada como uma desculpa genérica para a omissão estatal no campo da efetivação dos direitos fundamentais, principalmente os de cunho social". (p.11) "No caso dos autos, não houve essa 
Ficha 2 - Análise do acórdão do Resp n ${ }^{\circ}$ 1.804.607/MS

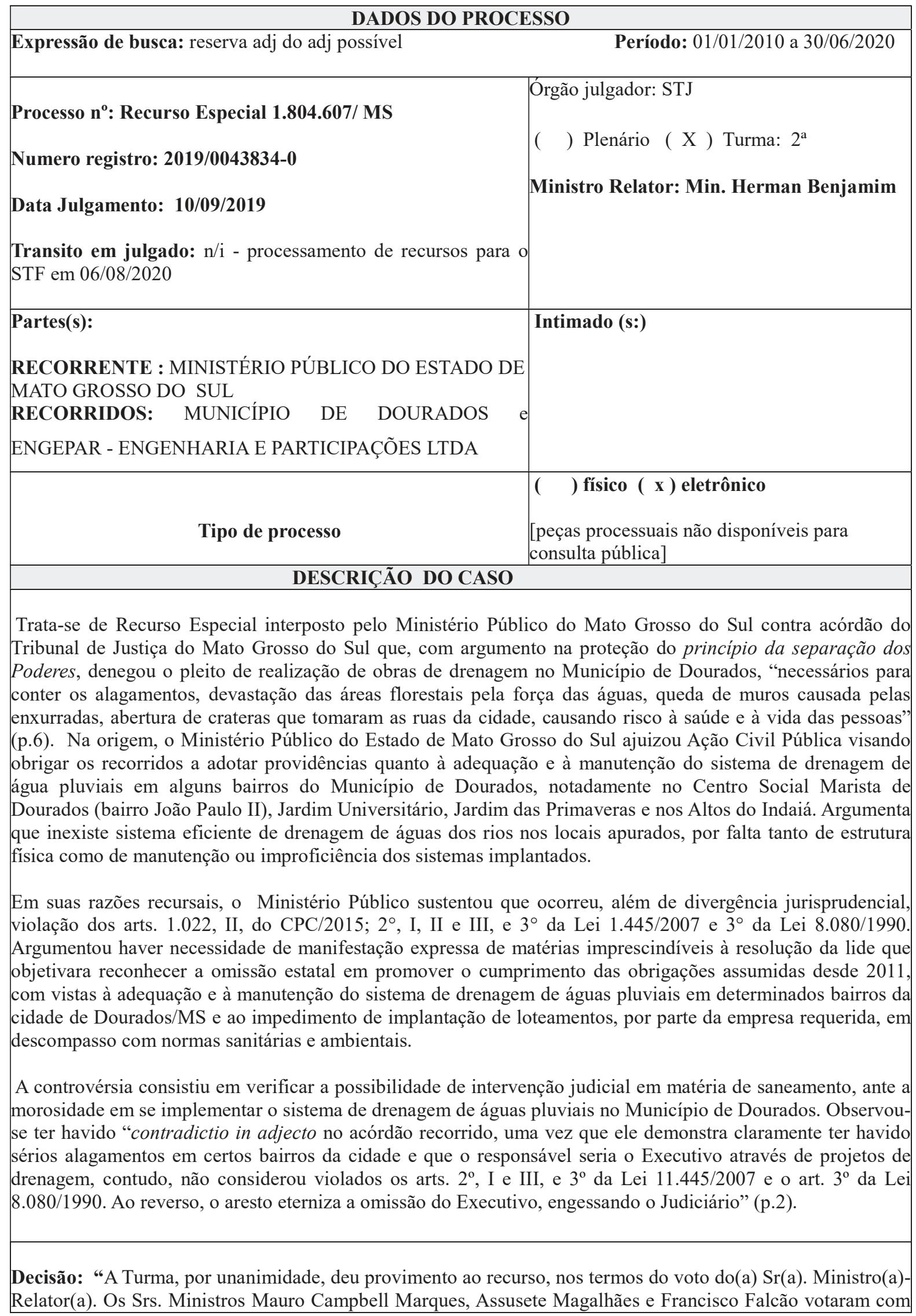


o Sr. Ministro Relator"'.

\section{A) Razões Gerais:}

\section{PRINCIPAIS RAZÕES DA DECISÃO:}

A.1) Pelo entendimento do Supremo Tribunal Federal: “O Poder Judiciário, em situações excepcionais, pode determinar que a Administração Pública adote medidas assecuratórias de direitos constitucionalmente reconhecidos como essenciais, sem que isso configure violação do princípio da separação de poderes". (AI 708.667 AgR, Relator(a): Min. Dias Toffoli, Primeira Turma julgado em 28/2/2012). Nesse sentido: RE 595.595 AgR/SC - Rel Min. Eros Grau, julgado em 28.4.2009, DJe 29.5.2009 (p.1).

A.2) O STJ tem orientação de que, ante a demora ou inércia do Poder competente, o Poder Judiciário poderá determinar, em caráter excepcional, a implementação de políticas públicas para o cumprimento de deveres previstos no ordenamento constitucional, sem que isso configure invasão da discricionariedade ou afronta à reserva do possível (REsp 1.367.549/MG, Rel. Ministro Humberto Martins, Segunda Turma, DJe 8.9.2014) (p. $15)$.

A.3) Comprovado tecnicamente ser imprescindível, para o meio ambiente, a realização de obras de drenagem, tem o Judiciário legitimidade para exigir o cumprimento da norma (ex: REsp 575.998/MG, Rel. Min. Luiz Fux, Primeira Turma,DJ 16.11.2004, e REsp 429.570/G0, Rel. Min. Eliana Calmon, Segunda Turma, DJ 22.3.2004) (p.16) . O relator entendeu que o "contexto fático foi analisado pelo Tribunal de origem, não se há falar em reexame de matéria fática, mas em revaloração jurídica, que não atrai a vedação imposta pela Súmula 7/STJ".

A.4) "A ilicitude gerada pelo não cumprimento injustificado do dever da Administração Pública em implementar políticas de governo acarreta a desarmonia da Ordem Jurídica, o que faz merecer correção judicial, sob pena de transformar em letra morta os direitos sociais. Dessa forma, não podem os direitos sociais ficar condicionados à boa vontade do Administrador, sendo de fundamental importância que o Judiciário atue como órgão controlador da atividade administrativa" (p.11).

A.5) "Nesse sentido, a correta interpretação do princípio da separação dos Poderes, em matéria de políticas públicas, deve ser a de utilizá-lo apenas para limitar a atuação do Judiciário quando a Administração Pública atua dentro dos limites concedidos pela lei. Fora daí, quando a Administração extrapola os limites da competência que lhe fora atribuída e age sem sentido, ou fugindo da finalidade à qual estava vinculada, não se aplica o referido princípio, e autorizado se encontra o Poder Judiciário a reconhecer que o Executivo não cumpriu com sua obrigação legal (agredindo com isso, direitos difusos e coletivos) e a corrigir tal distorção restaurando a ordem jurídica violada. Em suma, a atuação do Poder Judiciário no controle das políticas públicas não pode se dar de forma indiscriminada, pois isso violaria o princípio da separação dos Poderes. No entanto, quando a Administração Pública, de maneira clara e indubitável, viola direitos fundamentais por meio da execução ou falta injustificada de programas de governo, a interferência do Poder Judiciário é perfeitamente legítima e serve como instrumento para restabelecer a integridade da ordem jurídica ultrajada...” (p.12).

A.6) "[...] ainda que abstratamente, não se pode deixar de reconhecer que alguns direitos, tais como a educação, a saúde e o meio ambiente equilibrado, fazem parte de um núcleo de obrigações que o estado deve considerar como prioritárias" (p.13).

\section{B) Razões que tratam da incidência da reserva do possível:}

B.1) O "STJ possui firme orientação de que, ante a demora ou a inércia do Poder competente, o Poder Judiciário poderá determinar, em caráter excepcional, a implementação de políticas públicas para o cumprimento de deveres previstos no ordenamento constitucional, sem que isso configure invasão da discricionariedade ou afronta à reserva do possível (REsp 1.367.549/MG, Rel. Ministro Humberto Martins, Segunda Turma, DJe 8.9.2014)” (p.15).

B.2) “Ocorre que o recorrido vem protelando, há mais de sete anos, a implementação dessas benfeitorias, sem comprovar de forma objetiva e cabal a sua incapacidade econômico-financeira” (p.16).

B.3) "De fato, não se pode desconsiderar que as limitações orçamentárias são empecilhos para a efetivação dos direitos sociais, tais como o direito à saúde e ao saneamento básico. No entanto, é preciso frisar que o princípio da reserva do possível não pode ser alegado de forma aleatória e genérica, sobretudo quando estiverem em jogo obrigações que o Município de Dourados deve observar como prioritárias” (p.16). 


\begin{tabular}{|c|c|}
\hline $\begin{array}{l}\text { Direito fundamental/ princípio colidente com o } \\
\text { princípio da reserva do possível }\end{array}$ & $\begin{array}{l}\text { ( ) Saúde ( ) Educação ( ) Moradia } \\
\text { ( ) Alimentação ( } \quad \text { x ) Outros: meio ambiente } \\
\text { equlibrado }\end{array}$ \\
\hline $\begin{array}{l}\text { O princípio da reserva do possível prevaleceu na } \\
\text { decisão? }\end{array}$ & ( ) SIM ( X ) NÃO ( ) PREJUDICADO \\
\hline \multicolumn{2}{|c|}{ 1. PARÂMETROS DE CONFIABILIDADE EPISTÊMICA EMPIRICA } \\
\hline $\begin{array}{l}\text { I) Existência da prova documental suficiente à } \\
\text { comprovação do impacto orçamentário e/ou da } \\
\text { inexistência ou da insuficiência do crédito } \\
\text { orçamentário para o atendimento da prestação do } \\
\text { autor. }\end{array}$ & $\begin{array}{l}\text { ( ) NR ( } \mathrm{x}) \text { NÃO } \quad(\quad) \text { SIM } \\
\text { Qual(is) ?: }\end{array}$ \\
\hline $\begin{array}{l}\text { II) Não observância de dever jurídico orçamentário } \\
\text { em relação à fixação das despesas que contribuiu } \\
\text { para a insuficiência do recurso. }\end{array}$ & $\begin{array}{l}(\mathrm{x}) \mathrm{NR} \quad(\quad) \text { NÃO } \quad(\quad) \text { SIM } \\
\text { Qual(is) ?: }\end{array}$ \\
\hline $\begin{array}{l}\text { III) Não observância de dever jurídico orçamentário } \\
\text { sob o aspecto da receita que contribuiu para a } \\
\text { insuficiência do recurso. }\end{array}$ & $\begin{array}{ll}(\mathrm{x}) \mathrm{NR} \quad(\quad) \text { NÃO } \quad(\quad) \text { SIM } \\
\text { Qual(is) ?: }\end{array}$ \\
\hline $\begin{array}{l}\text { IV) Existe impossibilidade normativa de utilização } \\
\text { dos instrumentos de flexibilização orçamentária e da } \\
\text { reserva de contingência para a despesa que o autor } \\
\text { pleiteia? }\end{array}$ & $\begin{array}{l}(\mathrm{x}) \mathrm{NR} \quad(\quad) \text { NÃO } \quad(\quad) \text { SIM } \\
\text { Qual(is) ?: }\end{array}$ \\
\hline $\begin{array}{c}\text { Grau de confiabilidade sugerido às premissas } \\
\text { empíricas }\end{array}$ & $\begin{array}{l}\text { ( ) prejudicado ( } \mathrm{x} \text { ) não comprovado } \\
(\text { ) não evidentemente falso ( ) plausível } \\
\text { ( ) confiável }\end{array}$ \\
\hline \multicolumn{2}{|c|}{ 2. PARÂMETROS DE CONFIABILIDADE EPISTÊMICA NORMATIVA } \\
\hline $\begin{array}{l}\text { I) A alegação de insuficiência de recursos obsta } \\
\text { prestaçóes relativas ao mínimo existencial? }\end{array}$ & $\begin{array}{l}(\quad) \text { NR }\left(\begin{array}{llll} & x\end{array}\right) \text { NÃO } \quad(\quad) \text { SIM } \\
\text { Qual(is)? }\end{array}$ \\
\hline $\begin{array}{l}\text { II) Existe de decisão anterior do Tribunal ou } \\
\text { precedente que tenha estabelecido regra de } \\
\text { prevalência do princípio da reserva do possível, nas } \\
\text { mesmas condiçoes, em relação ao mesmo princípio } \\
\text { ou direito colidente? }\end{array}$ & $\begin{array}{l}\text { ( x ) NR ( ) SIM } \quad(\quad) \text { NÃO } \\
\text { [o precedente citado dá primazia ao direito ao meio } \\
\text { ambiente equilibrado em relação ao principio da } \\
\text { separação dos poderes] }\end{array}$ \\
\hline $\begin{array}{c}\text { Grau de confiabilidade sugerido às premissas } \\
\text { normativas }\end{array}$ & $\begin{array}{l}\text { ( ) prejudicada ( ) não comprovado } \\
(\mathrm{x} \text { ) não evidentemente falso ( ) plausível } \\
(\text { ) confiável }\end{array}$ \\
\hline
\end{tabular}

